\title{
Produção e purificação de um fragmento recombinante da proteína $A$ de superfície do clado 3 (PspA3) de Streptococcus pneumoniae em Escherichia coli
}

\section{RIMENYS JUNIOR CARVALHO}

Dissertação apresentada ao Programa de PósGraduação Interunidades em Biotecnologia USP/Instituto Butantan/IPT, para obtenção do Título de Mestre em Biotecnologia. 


\section{Produção e purificação de um fragmento recombinante da proteína $A$ de superfície do clado 3 (PspA3) de Streptococcus pneumoniae em Escherichia coli}

\section{RIMENYS JUNIOR CARVALHO}

Dissertação apresentada ao Programa de PósGraduação Interunidades em Biotecnologia USP/Instituto Butantan/IPT, para obtenção do Título de Mestre em Biotecnologia.

Área de Concentração: Biotecnologia

Orientadora: Dra. Viviane Maimoni Gonçalves 
DADOS DE CATALOGAÇÃO NA PUBLICAÇÃO (CIP)

Serviço de Biblioteca e Informação Biomédica do

Instituto de Ciências Biomédicas da Universidade de São Paulo

(c) reprodução total

Carvalho, Rimenys Junior

Produção e purificação de um fragmento recombinante da proteína A de superfície do clado 3 (PspA3) de Streptococcus pneumoniae em Escherichia coli / Rimenys Junior Carvalho. -- São Paulo, 2009.

Orientadora: Viviane Maimoni Gonçalves.

Dissertação (Mestrado) - Universidade de São Paulo. Instituto de Ciências Biomédicas. Programa de Pós-Graduação Interunidades em Biotecnologia USP/IPT/Instituto Butantan. Área de concentração: Biotecnologia. Linha de pesquisa: Produção e purificação de proteínas recombinantes.

Versão do título para o inglês: Production and purification of a recombinant fragment of pneumococcal surface protein A clade 3 (PspA3) from Streptococcus pneumoniae in Escherichia coli.

Descritores: 1. Streptococcus pneumoniae 2. Escherichia coli 3. Alta densidade celular 4. Clarificação 5. Purificação de proteína recombinante 6. Cromatografia líquida I. Gonçalves, Viviane Maimoni II. Universidade de São Paulo. Instituto de Ciências Biomédicas. Programa de Pós-Graduação em Biotecnologia III. Título. 
UNIVERSIDADE DE SÃO PAULO

Programa de Pós-Graduação Interunidades em Biotecnologia

Universidade de São Paulo, Instituto Butantan, Instituto de Pesquisas Tecnológicas

Candidato(a): $\quad$ Rimenys Junior Carvalho

Título da Dissertação: $\quad$ Produção e purificação de um fragmento recombinante da proteína A de superfície do clado 3 (PspA3) de Streptococcus pneumoniae em Escherichia coli.

Orientador(a): $\quad$ Viviane Maimoni Gonçalves.

A Comissão Julgadora dos trabalhos de Defesa da Dissertação de Mestrado, em sessão pública realizada a . .l.

\section{( ) Aprovado(a) ( ) Reprovado(a)}

Examinador(a): Assinatura:

Nome:

Instituição:

Examinador(a): Assinatura:

Nome:

Instituição:

Presidente: Assinatura:

Nome:

Instituição: 
Dedico este trabalho a algumas pessoas que foram essenciais para que ele pudesse ser realizado: aos meus pais Adélio e Nanci pela dedicação, carinho e apoio, a minha irmã Elaine, ao meu cunhado Gledson, minha sobrinha Laura e aos meus tios Élio e Azuir e primos Helen e Ítalo, pela confiança e apoio ao me acolherem em suas casas e, finalmente, a minha orientadora Dra. Viviane pela extrema dedicação a todo o momento durante a execução desse trabalho. Com o mesmo carinho que recebi durante esse tempo, dedico esse trabalho tão importante para mim a vocês! 


\section{Agradecimentos}

Primeiramente ao Instituto Butantan por ter fornecido o espaço e o material de trabalho.

À Dra. Eliane Miyaji, do Centro de Biotecnologia do Instituto Butantan, pelo fornecimento da cepa recombinante utilizado neste trabalho o qual foi importantíssimo para o sucesso deste.

Ao CNPq, pelo fornecimento da bolsa auxílio, sem a qual não teria conseguido realizar este trabalho a tempo, também à FAPESP pela aprovação do projeto temático o qual este trabalho está inserido.

Aos amigos e colegas de trabalho do Laboratório de Biopressos do Centro de Biotecnologia do Instituto Butantan. Aos pesquisadores Dra. Elisabete Sbrogio, Dra. Mickie, Dr. Pradella e Dra. Célia, que mesmo não ligados diretamente ao projeto, me apoiaram e ensinaram brilhantemente durante os trabalhos desenvolvidos. Aos técnicos Lourivaldo, Inês, Ana e Élio, pela ajuda e apoio nos trabalhos. Aos amigos e colegas de trabalho Mateus, Daniel, Roger, Verônica, Talita, Sílvia, Cíntia, Carol, Natália, Beatriz, Bruno e Rose, pela ajuda obtida nos trabalhos.

A todos os amigos do Instituto Butantan fora do laboratório e também aos amigos em geral por estarem sempre presentes e, de alguma forma incentivaram e reconheceram meu trabalho.

À banca de qualificação Dr. Adalberto, Dra. Francislene e Dr. Ivo pela disponibilidade e importante ajuda recebida na qualificação.

Aos pesquisadores do Centro de Biotecnologia do Instituto Butantan que de alguma forma ajudaram no desenvolvimento do trabalho durante a execução com o conhecimento e apoio material.

Aos meus maravilhosos pais Adélio e Nanci, por estarem sempre presentes mesmo morando em outra cidade. Pela formação obtida e não só como um profissional, mas pela formação pessoal o que é em grande parte a base das minhas vitórias alcançadas.

Pelas outras famílias conquistadas em São Paulo, minha irmã Elaine, meu cunhado Gledson, minha sobrinha Laura, meus tios Élio e Azuir e meus primos Helen e Ítalo, os quais me acolheram com carinho em suas casas por todo o período 
deste trabalho e terem permitido que eu fizesse parte de sua família, pela convivência, respeito e apoio.

Ao meu co-orientador Dr. Joaquin Cabrera-Crespo, pela grande ajuda obtida durante este trabalho e mesmo não sendo formalmente co-orientador foi indispensável para o sucesso deste trabalho.

À minha orientadora Dra. Viviane Maimoni Gonçalves, que não mediu esforços para que este trabalho pudesse ser realizado. Pelos ensinamentos, apoio, presença, humanidade, reconhecimento, críticas, enfim, por toda ajuda obtida durante o desenvolvimento deste trabalho a qual é grande responsável pela minha formação de mestre.

E, finalmente, a Deus por ter me iluminado para o melhor caminho a seguir, por ter colocado pessoas hoje indispensáveis na minha vida pessoal e profissional.

Este é um trabalho especial feito em equipe o qual tem um pouco de todos! 
"Nossas dúvidas são traidoras e nos fazem perder o bem que poderíamos conquistar se não fosse o medo de tentar."

Willian Shakespeare 


\section{Resumo}

CARVALHO, R. Jr. Produção e purificação de um fragmento recombinante da proteína A de superfície do clado 3 (PspA3) de Streptococcus pneumoniae em Escherichia coli. 2009. Dissertação (Mestrado em Biotecnologia) - Instituto de Ciências Biomédicas, Universidade de São Paulo, São Paulo, 2009.

Novas vacinas contra Streptococcus pneumoniae vem sendo estudadas, entre elas uma nova vacina conjugada utilizando como carregadoras proteínas de superfície do próprio S. pneumoniae. A proteína "pneumococal surface protein A" (PspA) foi escolhida por ser uma proteína de superfície indispensável para a virulência da bactéria. Assim, este trabalho propôs o desenvolvimento de um processo industrial de produção e purificação de um fragmento recombinante da PspA clado 3 (rfPspA3) em E. coli BL21(DE3). Testes cinéticos foram realizados e, posteriormente, cultivos descontínuos alimentados em meio definido foram feitos com glicose ou com glicerol como fonte de carbono em biorreator de $5 \mathrm{~L}$, obtendo-se $62 \mathrm{~g} / \mathrm{L}$ de massa celular seca e $\sim 3 \mathrm{~g} / \mathrm{L}$ de $\mathrm{rfPspA}$. As células foram lisadas por homogeneizador contínuo de alta pressão com eficiência de 96,7\%. Em seguida, para a etapa de clarificação, além da centrifugação, foram testadas micro e ultra filtração tangencial, as quais ocasionaram perda de $\operatorname{rfPspA} 3(58 \%$ e $29 \%$, respectivamente), definindo-se portanto a centrifugação para esta etapa. Duas etapas cromatográficas foram determinadas, troca aniônica (Q-Sepharose) e afinidade por metal (IMAC-Sepharose) carregada com $\mathrm{Ni}^{+2}$, e as duas possíveis sequências foram avaliadas. A sequência $Q$ seguida pela IMAC-Sepharose rendeu melhores resultados de pureza e recuperação ( 81 e $70 \%$, respectivamente). Para a terceira etapa foram avaliadas: a cromatografia hidrofóbica (Phenyl-Sepharose), a gel filtração (Sephacryl S-200 HR) e a troca catiônica (SP-Sepharose). A última foi escolhida para compor o processo de purificação. Os resultados da purificação do material proveniente dos cultivos em alta densidade com glicose ou glicerol foram então comparados e não foram encontradas diferenças relevantes para a QSepharose. A pureza final do rfPspA3 foi de $90 \%$, porém o rendimento da última etapa foi menor que o obtido quando da definição do processo. Concluindo, um processo de produção e purificação escalonável foi desenvolvido e possibilitou a obtenção de rfPspA3 com um alto grau de pureza (90\%).

Palavras-chave: Strepcoccus pneumoniae. Escherichia coli. Alta densidade celular. Clarificação. Purificação de proteína recombinante. Cromatografia líquida. 


\section{Abstract}

CARVALHO, R. Jr. Production and purification of a recombinant fragment of pneumococcal surface protein A clade 3 (PspA3) from Streptococcus pneumoniae in Escherichia coli. 2009. Master thesis (Biotechnology) - Instituto de Ciências Biomédicas, Universidade de São Paulo, São Paulo, 2009.

New vaccines against Streptococcus pneumoniae have been developed, among them a new conjugated vaccine using as carriers pneumococcal surface proteins has been studied. The protein pneumococcal surface protein A (PspA) was the first choice as carrier because it is indispensable for virulence of $S$. pneumoniae. Hence, the purpose of this work was to develop an industrial production and purification process of a recombinant fragment of PspA clade 3 (rfPspA3) in E. coli BL21(DE3). Kinetic assays were performed, and then fed-batch cultivations in $5 \mathrm{~L}$ bioreactors with defined medium were carried out using glucose or glycerol as carbon sources. It was obtained $62 \mathrm{~g} / \mathrm{L}$ of dry cell weight and $3 \mathrm{~g} / \mathrm{L}$ of rfPspA3. Cells were disrupted with $96.7 \%$ of efficiency by high pressure continuous homogenizer. For the clarification step, besides centrifugation, it was tested cross flow micro and ultra filtrations in hollow fibers, but these methods led to rfPspA3 loss (58\% and $29 \%$, respectively). Therefore, centrifugation was defined for the clarification step. Two chromatographic steps and the best sequence of them were analyzed: anion exchange (Q-Sepharose) and metal affinity (IMAC-Sepharose). The sequence with $Q$ followed by IMAC-Sepharose yielded the best purity and recovery of rfPspA3 (81 and $70 \%$, respectively). For the third chromatographic step, three methods were evaluated: hydrophobic interaction (Phenyl-Sepharose), gel filtration (Sephacryl S$200 \mathrm{HR}$ ) and cation exchange (SP-Sepharose). The last one was chosen for the purification process. The results of rfPspA3 purification from cultures using glucose or glycerol were compared and no relevant differences were found in the Q-Sepharose step. The final purity of $\mathrm{rfPspA} 3$ was $90 \%$, but the recovery of the last chromatography was lower than previously obtained. In conclusion, an industrial production and purification process was developed and rfPspA3 was obtained with high purity (90\%).

Keywords: Streptococcus pneumoniae. Escherichia coli. High cell density. Clarification. Recombinant protein purification. Liquid chromatography. 


\section{Lista de Abreviaturas}

PS - Polissacarídeos

E. coli BL21(DE3) - Bactéria Escherichia coli cepa BL21 com o gene do fago DE3 inserido em seu gene

PspA - pneumococcal surface protein A (proteína pneumocócica A de superfície) rfPspA3 - Fragmento recombinante da proteína PspA clado 3

IPTG - Isopropil- $\beta$-D-tiogalactopiranosídeo

DNA - Ácido desoxirribonucléico

RNA - Ácido ribonucléico

mRNA - Ácido ribonucléico mensageiro

OMS - Organização Mundial da Saúde

FDA - Food and Drug Administration

CIP - Cleaning in place

SIP - Satinization in place

Kan - Antibiótico kanamicina

LB - Meio de cultivo complexo Luria Bertani

MQD - Meio de cultivo quimicamente definido

$\mathrm{DO}_{600 \mathrm{~nm}}$ - Densidade óptica à $600 \mathrm{~nm}$ de comprimento de onda

SDS-PAGE - Sodium dodecyl sulfate polyacrylamide gel electrophoresis

(Dodecilsulfato de sódio - eletroforese de gel de poliacrilamida)

$\mathrm{pl}$ - Ponto isoelétrico

$\mathrm{RF}$ - Relative front (distância percorrida pela biomolécula em um gel de eletroforese

em relação à distância total do gel)

EDTA - Ácido etilenodiamino-tetra-acético 
Tris - Tris(hidroximetil)aminometano

PMSF - Fenilmetanosulfonilfluorídrico

PPG - Polipropilenoglicol

IMAC - Immobilized metal affinity chromatography (Cromatografia de afinidade por metais)

HPLC - High performance liquid chromatography (Cromatografia líquida de alta eficiência)

HPSEC - High performance size-exclusion chromatography (Cromatografia de exclusão molecular de alta eficiência)

RID - Detector de índice de refração

UFC - Unidade formadora de colônia

CD - Dicroísmo circular

UV - Ultravioleta 


\section{Lista de Nomenclaturas}

$\mathrm{m}_{\mathrm{s}}(t)=$ Fluxo mássico de alimentação de substrato em função do tempo $(\mathrm{g} / \mathrm{h})$

$\mathrm{V}_{0}=$ Volume do reator no início da alimentação (L)

$\mathrm{X}_{0}=$ Concentração celular no início da alimentação $(\mathrm{g} / \mathrm{L})$

$\mathrm{S}=$ Concentração do substrato limitante dentro do reator $(\mathrm{g} / \mathrm{L})$

$\mathrm{S}_{\mathrm{f}}=$ Concentração do substrato limitante no meio do reator $(\mathrm{g} / \mathrm{L})$

e = Função matemática exponencial

$\mathrm{t}=$ tempo $(\mathrm{h})$

$\mathrm{t}_{0}=$ tempo no início da alimentação $(\mathrm{h})$

$\mathrm{Y}_{\mathrm{X} / \mathrm{S}}=$ Conversão de substrato em células ( $\mathrm{g}$ massa celular seca/g fonte carbono consumida)

m = coeficiente de manutenção celular $(0,025 \mathrm{~g} / \mathrm{g} . \mathrm{h})$

$\mathrm{kDa}=$ Quilodaltons

$\mathrm{FV}=$ Fluxo volumétrico $(\mathrm{mL} / \mathrm{min})$

$\mathrm{FL}=$ Fluxo linear $(\mathrm{cm} / \mathrm{h})$

$\mathrm{R}=$ Raio $(\mathrm{cm})$

$\pi=$ Letra grega de nome "pi" correspondente ao número $~ 3,1416$

$\mu_{\max }=$ velocidade máxima de crescimento celular $\left(\mathrm{h}^{-1}\right)$

$\mu_{\text {set }}=$ velocidade de crescimento celular no set point $\left(\mathrm{h}^{-1}\right)$

$\mu_{\text {crit }}=$ velocidade crítica de crescimento celular $\left(h^{-1}\right)$

$\mathrm{MS}=$ massa celular seca $(\mathrm{g} / \mathrm{L})$

Mtc $=$ massa do tubo contendo o pellet bacteriano $(\mathrm{g})$

Mtv = massa do tubo vazio para medida de massa celular $(\mathrm{g})$

$\mathrm{V}=$ volume $(\mathrm{L})$ 


\section{LISTA DE ILUSTRAÇÕES}

Figura 1.1: Taxa anual de mortalidade de crianças menores de 5 anos por doenças causadas por diferentes patógenos em todo o mundo, sendo que mais de 800.000 mortes são causadas somente por doenças pneumocócicas.

Figura 1.2: Estrutura da PspA, a barra estreita indica os fragmentos fPspA 1 e 3 clonados no Centro de Biotecnologia do Instituto Butantan.

Figura 1.3: Esquema da estrutura da parede celular do pneumococo e do ancoramento da PspA. A parte vermelha da proteína é helicoidal e eletronegativa e a parte azul é plana e eletropositiva. .29

Figura 1.4: Sistema de controle do óperon Lac. A) no cromossomo da bactéria com a produção de permease; B) no sistema pET com a indução da expressão do gene de interesse presente no vetor.

Figura 3.1: Etapas do processo de produção e purificação do fragmento recombinante da PspA3.

Figura 3.2: Homogeneizador contínuo de alta pressão APV-Gauling utilizado para lise celular de E. coli.....

Figura 3.3: Estação de trabalho Äkta Explorer da Amersham Pharmacia Biotech munido de 2 bombas. Na figura há o computador que monitora e controla o sistema on-line do processo através do software Unicorn 3.21 e a coluna XK 26 com $75 \mathrm{~mL}$ da resina SP-Sepharose Fast-Flow.

Figura 4.1: Gel de eletroforese do teste de expressão de 4 diferentes colônias da $E$.

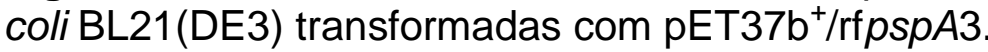

Figura 4.2: Curva de crescimento nos meios LB e MQD utilizando E. coli BL21(DE3) carregando $\mathrm{pET} 37 \mathrm{~b}+/ \mathrm{rfpspA3}$.

Figura 4.3: A - Eletroforese do rfPspA3 no meio LB. B - Eletroforese do rfPspA3 no meio MQD. 58

Figura 4.4: Parâmetros do cultivo descontínuo de E. coli BL21(DE3) em meio MQD utilizando glicose como fonte de carbono em biorreator de $5 \mathrm{~L}$ para produção de rfPspA3. A - Velocidade específica máxima de crescimento $\left(\mu_{\text {máx }}\right)$; B - Fator de conversão de substrato em células $\left(\mathrm{Y}_{\mathrm{X} / \mathrm{S}}\right)$.

Figura 4.5: Parâmetros do cultivo descontínuo de E. coli BL21(DE3) em meio MQD utilizando glicerol como fonte de carbono em biorreator de $5 \mathrm{~L}$ para produção de rfPspA3. A - Velocidade específica máxima de crescimento $\left(\mu_{\text {máx }}\right)$; $\mathbf{B}$ - Fator de conversão de substrato em células $\left(\mathrm{Y}_{\mathrm{X} / \mathrm{S}}\right)$ 59 
Figura 4.6: Cultivo Descontínuo de E. coli BL21(DE3)+pET37b ${ }^{+} / r f p s p A 3$ em meio MQD com glicose como fonte de carbono.

Figura 4.7: Cultivo Descontínuo de E. coli BL21(DE3)+pET37b/rfpspA3 em meio MQD com glicerol como fonte de carbono.

Figura 4.8: A - Gel de eletroforese da produção do rfPspA3 durante o cultivo descontínuo com glicose como fonte de carbono. B - Gel de eletroforese da produção do rfPspA3 durante o cultivo descontínuo com glicerol como fonte de carbono.

Figura 4.9: Gel de eletroforese com as frações obtidas na cromatografia IMACsepharose carregada com $\mathrm{Ni}^{+2}$ (com clarificados e eluições diluídos 10 vezes, fração não-adsorvida 5 vezes e lavagens sem diluição). A - Purificação a partir das células do cultivo em batelada com glicose. B - Purificação a partir das células do cultivo em batelada com glicerol

Figura 4.10: Cultivo descontínuo alimentado de E. coli BL21(DE3) para produção de rfPspA3 com glicose como fonte de carbono. 65

Figura 4.11: Cultivo descontínuo alimentado de E. coli BL21(DE3) para produção de rfPspA3 com glicerol como fonte de carbono.

Figura 4.12: Gel de eletroforese de rfPspA3 das amostras do cultivo descontínuo alimentado com glicose (A) e glicerol (B) como fonte de carbono. 68

Figura 4.13: Eletroforese de rfPspA3 produzido por E. coli BL21(DE3) dos testes da relação IPTG/células/tempo de indução com concentração de IPTG 1 mM/lactose 16 $\mathrm{g} / \mathrm{L}$ e variação de $\mathrm{DO}_{600 \mathrm{~nm}}$. Cada amostra foi ajustada em $\mathrm{DO}_{600 \mathrm{~nm}}$ igual a cinco para aplicação ao gel. A - 4 horas de indução e B - 12 horas

Figura 4.14: Eletroforese de rfPspA3 produzido por E. coli BL21(DE3) dos testes da relação IPTG/células/tempo de indução com concentração de IPTG 1 mM/lactose 16 $\mathrm{g} / \mathrm{L}$ e variação de $\mathrm{DO}_{600 \mathrm{~nm}}$. Foi aplicado ao gel $2 \mu \mathrm{L}$ de cada amostra . A -4 horas de indução e B - 12 horas.

Figura 4.15: Eletroforese de rfPspA3 produzido por E. coli BL21(DE3) dos testes da relação IPTG/células/tempo de indução com concentração celular fixa $\left(\mathrm{DO}_{600 \mathrm{~nm}}=\right.$ 140), lacose $16 \mathrm{~g} / \mathrm{L}$ e variação da concentração de IPTG. Para cada teste, uma quantidade de células correspondente a $\mathrm{DO}_{600 \mathrm{~nm}}$ igual a cinco foi aplicada ao gel. $\mathrm{A}$ -4 horas de indução e B - 12 horas. .70

Figura 4.16: Perfil de produção de rfPspA3 em teste da relação IPTG/células/tempo de indução com concentração de IPTG $1 \mathrm{mM} /$ lactose $16 \mathrm{~g} / \mathrm{L}$. Área da banda do rfPspA3 (SDS-PAGE -Figura 4.13) versus relação $\mu$ mol IPTG/DO $600 \mathrm{~nm}$. SDS-PAGE de amostras com quantidade de células correspondentes à $\mathrm{DO}_{600 \mathrm{~nm}}=5,0$. 70

Figura 4.17: Perfil de produção de rfPspA3 em teste da relação IPTG/células/tempo de indução com concentração de IPTG $1 \mathrm{mM} /$ lactose $16 \mathrm{~g} / \mathrm{L}$ e variação da 
concentração celular. Área da banda do rfPspA3 (SDS-PAGE - Figura 4.14) versus relação $\mu \mathrm{mol} I P T G / D_{600 \mathrm{~nm}}$. SDS-PAGE de amostras com volume de $2 \mu \mathrm{L}$

Figura 4.18: Perfil de produção de rfPspA3 em teste da relação IPTG/células/tempo de indução com concentrações fixas de células $\left(D_{600 \mathrm{~nm}}=140\right)$ e lactose $16 \mathrm{~g} / \mathrm{L}$ e variação da concentração de IPTG analisado pela eletroforese SDS-PAGE (Figura 4.15). SDS-PAGE de amostras com quantidade de células correspondentes à $\mathrm{DO}_{600 \mathrm{~nm}}=5,0$

Figura 4.19: Sequência do fragmento recombinante da PspA3 utilizado neste trabalho.

Figura 4.20: Curva de titulação teórica do rfPspA3 obtido do programa .74

Figura 4.21: Géis de eletroforese do sobrenadante das amostras da lise celular mecânica em homogeneizador de alta pressão APV Gauling 60. A-Lise celular do cultivo com glicose como fonte de carbono e B- Lise celular do cultivo com glicerol como fonte de carbono.

Figura 4.22: Perfil da concentração de proteínas totais (A) e rfPspA3 (B) obtido em relação ao tempo de lise das células obtidas do cultivo de alta densidade com glicose como fonte de carbono e com glicerol.

Figura 4.23: Perfil da DO600nm e também de contagem de colônias pelo tempo de lise celular em homogeneizador de alta pressão Gaulin APV 60. Amostras a partir das células do cultivo em alta densidade com glicose como fonte de carbono e também com glicerol. 78

Figura 4.24: Gel de eletroforese do teste de solubilidade da proteína rfPspA3 feito por centrifugação do homogenato bruto da E. coli BL21(DE3) transformada com $\mathrm{pET} 37 \mathrm{~b}+/ \mathrm{rfpspA3}$ .79

Figura 4.25: Amostras obtidas após diferentes etapas de clarificação (10 $\mu \mathrm{g}$ de proteínas totais). .80

Figura 4.26: Foto dos clarificados em diferentes tratamentos. 81

Figura 4.27: Cromatogramas do homogenato bruto e das 3 clarificações 81

Figura 4.28: Gel de eletroforese do teste de solubilidade do rfPspA3 em diferentes $\mathrm{pH}$

Figura 4.29: Perfil da porcentagem de recuperação rfPspA3 e proteínas totais recuperadas no sobrenadante do clarificado centrifugado de E. coli BL21(DE3) submetido a diferentes $\mathrm{pH}$ e a indicação do pl teórico no gráfico.

Figura 4.30: Gel de eletroforese da adsorção do clarificado centrifugado em resina $\mathrm{Q}$-sepharose FF em diferentes $\mathrm{pH}$. 
Figura 4.31: 1-Gel de eletroforese de testes de adsorção do clarificado centrifugado em resina Q-Sepharose em diferentes $\mathrm{pH}$. 2-Western Blotting obtido a partir do gel de eletroforese 1

Figura 4.32: $\alpha$ e $\beta$-Géis de eletroforese do teste de adsorção do clarificado centrifugado em resina Q-sepharose em diferentes concentrações de $\mathrm{NaCl}$.

Figura 4.33: Porcentagem relativa de rfPspA3 nas frações não-adsorvidas em resina Q-Sepharose FF em diferentes concentrações de $\mathrm{NaCl}$.

Figura 4.34: Fluxograma do primeiro teste cromatográfico em coluna empacotada com resina de troca iônica Q-sepharose e gel de eletroforese SDS-PAGE de cada fração obtida conforme indicado pelas setas.

Figura 4.35: Fluxograma do segundo teste cromatográfico em coluna empacotada com resina de troca iônica Q-sepharose e gel de eletroforese SDS-PAGE de cada fração obtida conforme indicado pelas setas

Figura 4.36: Fluxograma do terceiro teste cromatográfico em coluna empacotada com resina de troca iônica Q-sepharose e gel de eletroforese SDS-PAGE de cada fração obtida conforme indicado pelas setas

Figura 4.37: Fluxograma do primeiro teste de eluição em coluna empacotada com resina de afinidade IMAC-sepharose Fast-Flow carregada com $\mathrm{Ni}^{+2}$ e abaixo o gel de eletroforese SDS-PAGE de cada etapa do processo indicada pela seta 94

Figura 4.38: Fluxograma do segundo teste de em coluna empacotada com resina de afinidade IMAC-sepharose $\mathrm{FF}$ carregada com $\mathrm{Ni}^{+2}$ e abaixo 0 gel de eletroforese SDS-PAGE de cada fração obtida indicada pela seta. 95

Figura 4.39: Fluxograma do terceiro teste em coluna empacotada com resina de afinidade IMAC-sepharose FF carregada com $\mathrm{Ni}^{+2}$ e abaixo o gel de eletroforese SDS-PAGE de cada fração indicada pela seta. .96

Figura 4.40: Esquemas dos processos de purificação de rfPspA3 testados para estabelecer a sequência das etapas cromatográficas 97

Figura 4.41: Condições da cromatografia utilizando coluna com $500 \mathrm{~mL}$ de QSepharose Fast-Flow para estabelecer a sequência das etapas de purificação de rfPspA3. 98

Figura 4.42: Condições da cromatografia utilizando $500 \mathrm{~mL}$ de IMAC-Sepharose Fast-Flow carregada com $\mathrm{Ni}^{+2}$ para estabelecer a sequência das etapas de purificação de rfPspA3. .98

Figura 4.43: Cromatogramas e SDS-PAGE das frações da primeira sequência cromatográfica em Q-Sepharose seguida de IMAC-Sepharose .99

Figura 4.44: Cromatogramas e SDS-PAGE das frações da segunda sequência de cromatografias em IMAC-Sepharose seguida de Q-Sepharose. 100 
Figura 4.45: A-Cromatograma da purificação em Sephacryl S-200 HR da amostra de eluição da segunda cromatografia IMAC-Sepharose. B1 e B2-Géis de eletroforese SDS-PAGE das frações coletadas a partir de $80 \mathrm{~mL}$ de eluição até $330 \mathrm{~mL}$ indicada pelas setas vermelhas 102

Figura 4.46: Gel de eletroforese SDS-PAGE não redutor das frações obtidas do pico do cromatograma (Figura $4.45 \mathrm{~A}$ ) 103

Figura 4.47: Gel de eletroforese do teste de adsorção em tubos com a resina Phenyl-Sepharose. 104

Figura 4.48: Géis de eletroforese dos testes de dessorção em coluna empacotada com resina Phenyl-Sepharose High Sub Fast Flow. A-Teste realizado com $\mathrm{NaCl}$ e BTeste realizado com $\left(\mathrm{NH}_{4}\right)_{2} \mathrm{SO}_{4}$ 105

Figura 4.49: Gel de eletroforese do teste de precipitação isoelétrica com amostra purificada em duas etapas cromatográficas. 106

Figura 4.50: Gel de eletroforese do teste de adsorção em tubos com resina SPSepharose

Figura 4.51: Gel de eletroforese do teste de adsorção em tubos com resina SPSepharose na faixa de $\mathrm{pH}$ de 5,0 a 6,5 108

Figura 4.52: Estrutura tridimensional do fragmento protéico da PspA estudado por Jedrzejas et al. ${ }^{12}$

Figura 4.53: Gel de eletroforese do teste de adsorção em tubos à resina SPSepharose em diferentes concentrações de $\mathrm{NaCl}$ à $\mathrm{pH}$ 6,0 109

Figura 4.54: Gel de eletroforese do terceiro teste de eluição em coluna empacotada com resina SP-Sepharose Fast Flow em pH 7,0 com diferentes concentrações de $\mathrm{NaCl}$

Figura 4.55: Gel de eletroforese do teste de eluição com diferentes concentrações de tampão fosfato $\mathrm{pH}$ 7,0 em coluna empacotada com resina SP-Sepharose Fast Flow.

Figura 4.56: Condições da cromatografia SP-Sepharose Fast-Flow determinada como última etapa cromatográfica da sequência de purificação de rfPspA3

Figura 4.57: Fluxograma das etapas cromatográficas definidas para purificação de rfPspA3.

Figura 4.58: Fluxograma das etapas de purificação realizadas e suas respectivas condições de eluição para purificação do rfPspA3 114

Figura 4.59: Géis de eletroforese SDS-PAGE da primeira cromatografia QSepharose utilizando clarificado obtido do cultivo com glicose como fonte de carbono (A) e glicerol (B) 
Figura 4.60: Géis de eletroforese SDS-PAGE da segunda cromatografia IMACSepharose utilizando clarificado obtido do cultivo com glicose como fonte de carbono (A) e glicerol (B)

Figura 4.61: Géis de eletroforese SDS-PAGE da terceira cromatografia SPSepharose utilizando clarificado obtido do cultivo com glicose como fonte de carbono (A) e glicerol (B) 116

Figura 4.62: Cromatogramas do clarificado centrifugado e frações de eluição das etapas cromatográficas de purificação da amostra proveniente do cultivo em alta densidade com glicose como fonte de carbono.

Figura 4.63: Cromatogramas do clarificado centrifugado e frações de eluição das etapas cromatográficas de purificação da amostra proveniente do cultivo em alta densidade com glicerol como fonte de carbono 118

Figura 4.64: Gel de eletroforese SDS-PAGE da amostra de eluição da terceira etapa cromatográfica SP-Sepharose Fast Flow obtida da produção com glicerol como fonte de carbono em diferentes quantidades de proteínas totais. 120

Figura 4.65: Espectro CD do rfPspA3 purificado a partir do cultivo com glicerol....121

Figura 4.66: Espectro de CD obtido nas construções de PspA Rx1314 e Rx1314MI segundo Jedrzejas et al. ${ }^{12}$ 


\section{LISTA DE TABELAS}

Tabela 3.1: Composição do meio LB

Tabela 3.2: Composição do meio quimicamente definido (MQD) para ensaios em frascos.

Tabela 3.3: Composição do meio de alimentação para os cultivos em batelada alimentada.

Tabela 4.1: Porcentagem de colônias resistentes à kanamicina durante o cultivo descontínuo de $E$. coli BL21(DE3)+pET37brfpspA3.

Tabela 4.2: Comparação do rfPspA3 obtido nos cultivos descontínuos após a cromatografia de afinidade por metal.

Tabela 4.3: Composição de aminoácidos do rfPspA3 obtida pela análise de sua seqüência pelo programa.

Tabela 4.4: Dados finais dos cultivos em biorreator de $5 \mathrm{~L}$ após separação das células do meio de cultivo .75

Tabela 4.5: Pureza relativa do rfPspA3 antes e após centrifugação .80

Tabela 4.6: Tabela de purificação dos clarificados obtidos por centrifugação, microfiltração e ultrafiltração

Tabela 4.7: Pureza relativa do rfPspA3 no precipitado e sobrenadante das amostras do homogenato a diferentes $\mathrm{pH}$.

Tabela 4.8: Pureza relativa do rfPspA3, sua concentração e recuperação nas frações não-adsorvidas em resina de troca-aniônica Q-sepharose em diferentes $\mathrm{pH}$

Tabela 4.9: Concentração de $\mathrm{NaCl}$ na solução tampão acetato $25 \mathrm{mM}$ e sua respectiva condutividade.

Tabela 4.10: Tabela de purificação de rfPspA3 do terceiro teste de dessorção com a resina Q-sepharose.

Tabela 4.11: Tabela de purificação de rfPspA3 do terceiro teste de dessorção com a resina IMAC-Sepharose.

Tabela 4.12: Tabela de purificação de rfPspA3 em Q-Sepharose seguida de IMACSepharose

Tabela 4.13: Tabela de purificação de rfPspA3 em IMAC-Sepharose seguida de QSepharose. 
Tabela 4.14: Concentrações dos sais $\mathrm{NaCl}$ e $(\mathrm{NH} 4) 2 \mathrm{SO} 4$ utilizados no teste de adsorção em tubos à resina Phenyl-Sepharose.

Tabela 4.15: Tabela de purificação da amostra proveniente do cultivo em alta densidade com glicose como fonte de carbono.....................................................118

Tabela 4.16: Tabela de purificação da amostra proveniente do cultivo em alta densidade com glicerol como fonte de carbono.

Tabela 4.17: Pureza relativa de rfPspA3 purificado a partir do cultivo com glicerol. 


\section{SUMÁRIO}

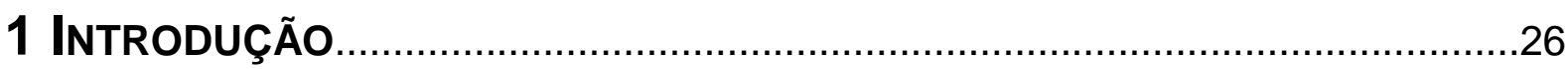

1.1 CULTIVO

1.2 PURIFICAÇÃO

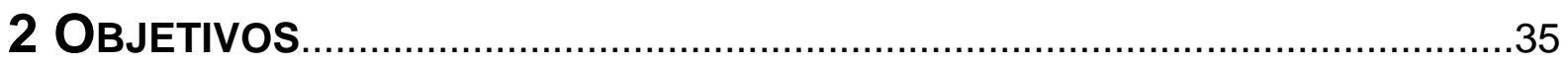

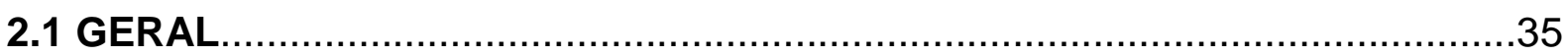

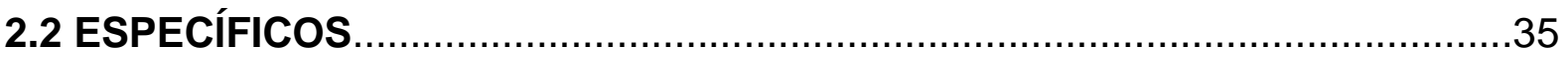

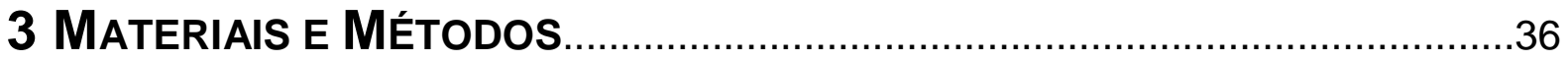

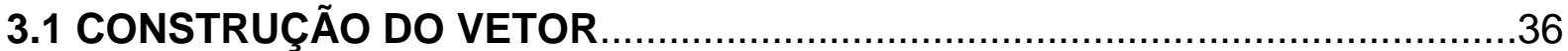

3.2 ETAPAS DO PROCESSO DE PRODUÇÃO E PURIFICAÇÃO DO rfPspA3.....37

3.3 PRODUÇÃO DO fPspA3 EM E. coli BL21 (DE3) - UPSTREAM....................38

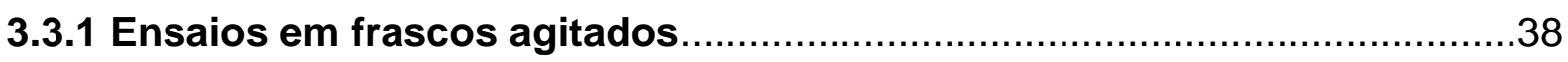

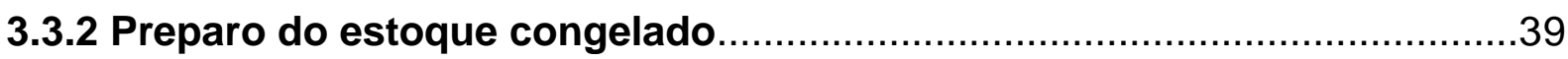

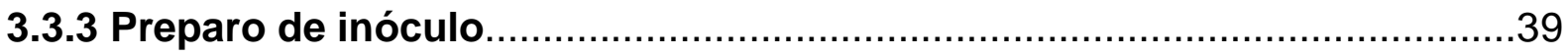

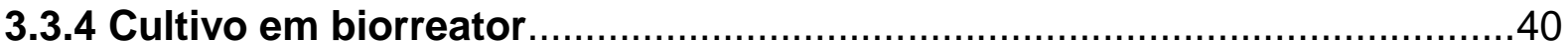

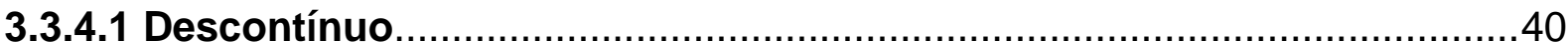

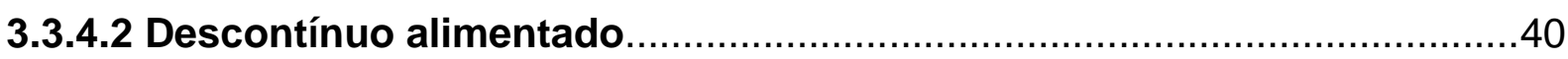

3.3.4.3 Estudo da relação IPTG/ células/ tempo de indução..............................41

Variação da concentração celular (concentração fixa de IPTG).........................42

Variação da concentração de IPTG (concentração celular fixa)........................42

3.4 ETAPAS DE PURIFICAÇÃO PROTÉICA - DOWNSTREAM.........................43

3.4.1 Separação celular do meio fermentado .....................................................

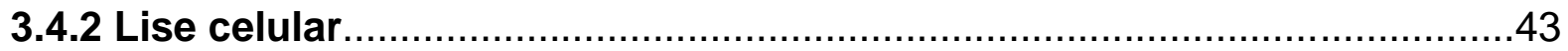

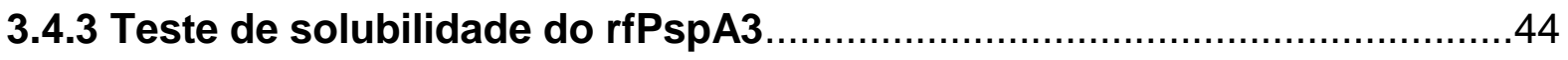

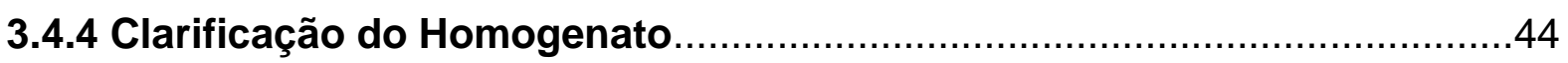

3.4.5 Teste de precipitação do rfPspA3 em diferentes pH..............................45

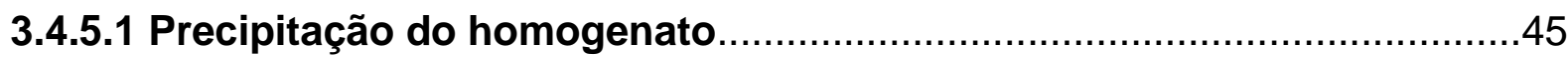

3.4.5.2 Precipitação isoelétrica da fração de eluição da segunda cromatografia

3.4.6 Cromatografia: resinas, colunas e etapas das cromatografias estudadas. 
3.4.7 Testes prévios de adsorção em tubos com as resinas

3.4.7.1 Amostras

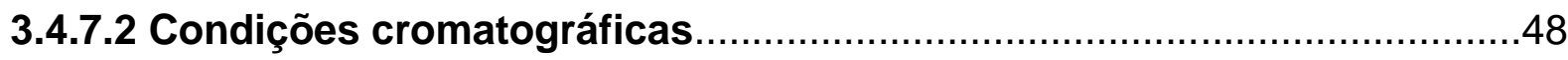

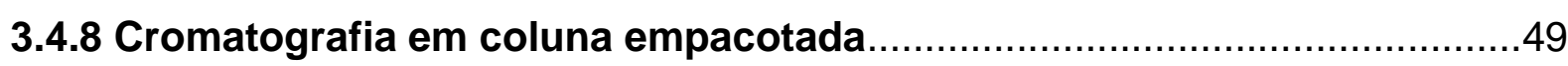

3.4.8.1 Estabelecimento das condições de dessorção em coluna empacotada.

3.4.8.2 Estabelecimento da sequência das etapas cromatográficas.................51

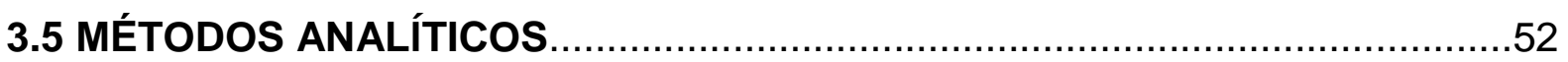

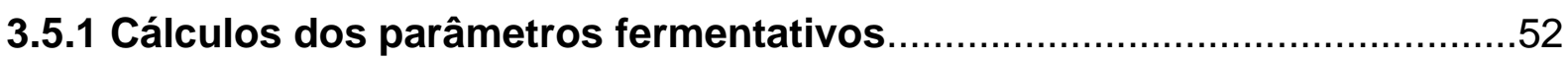

3.5.2 Determinação da relação massa seca $\times \mathrm{DO}_{600 \mathrm{~nm}}$ de suspensões celulares. .52

3.5.3 Determinação da concentração de glicose, glicerol e ácido acético.........53

3.5.4 Determinação da estabilidade do plasmídeo...........................................53

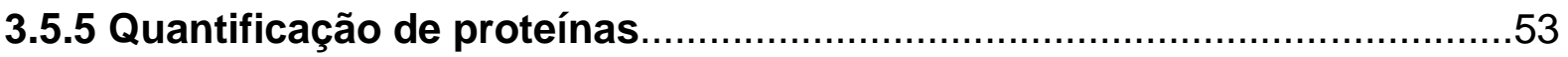

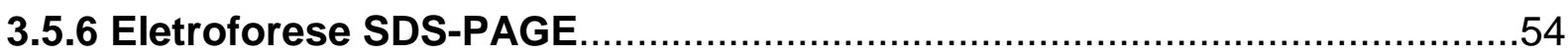

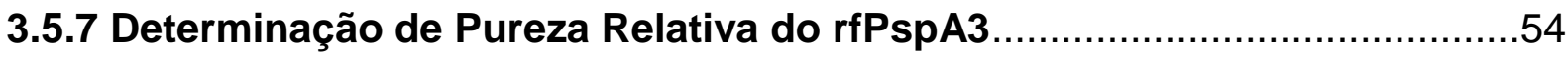

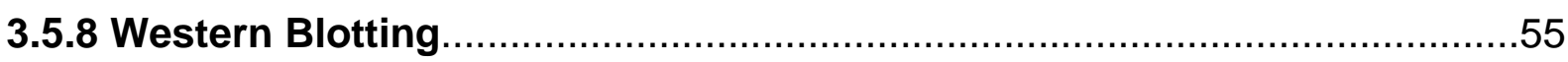

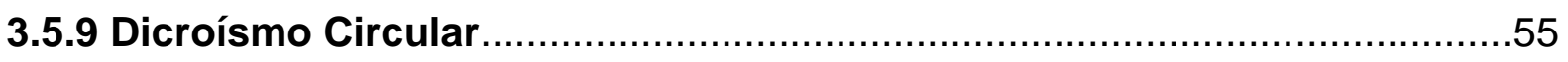

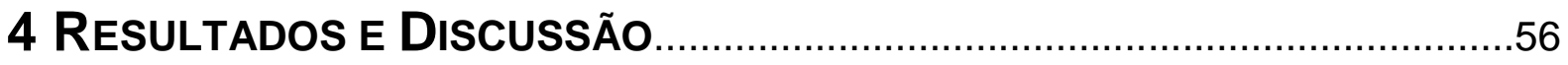

4.1 EXPRESSÃO DO GENE E CINÉTICA DE CRESCIMENTO DE E. coli

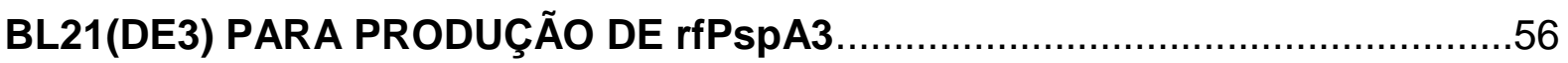

4.1.1 Testes de expressão do gene fPspA3 em E. coli BL21(DE3) e seleção do

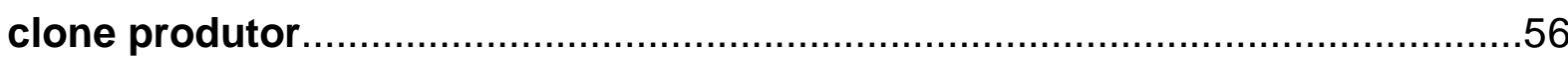

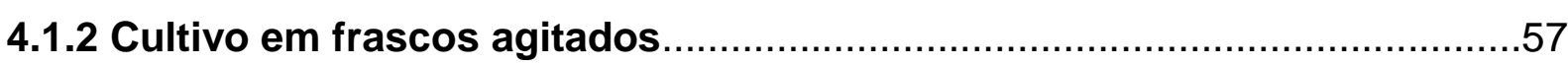

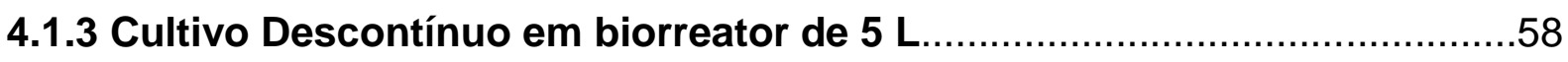

4.1.3.1 Purificação do rfPspA3 dos cultivos descontínuos.................................63

4.1.4 Cultivo Descontínuo Alimentado de E. coli BL21 (DE3) para produção de

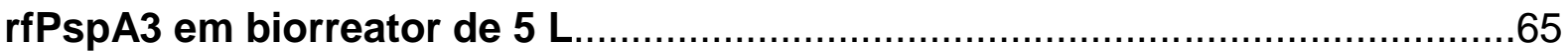

4.1.5 Estudo da relação IPTG/ células/ tempo de indução...................................68

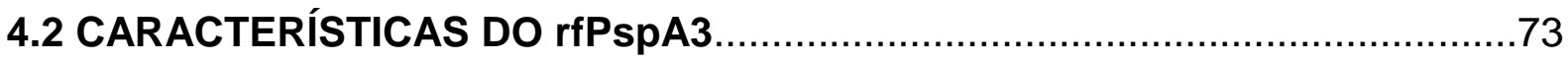

4.3 DESENVOLVIMENTO DO PROCESSO DE PURIFICAÇÃO DO rfPspA3........75

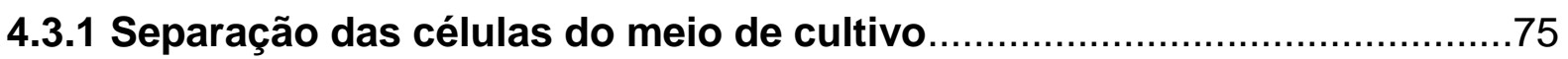

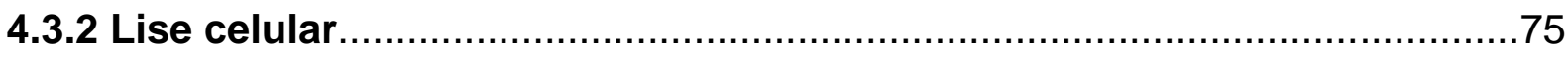




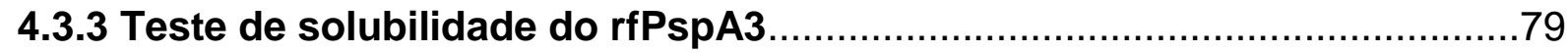

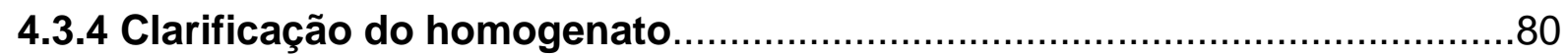

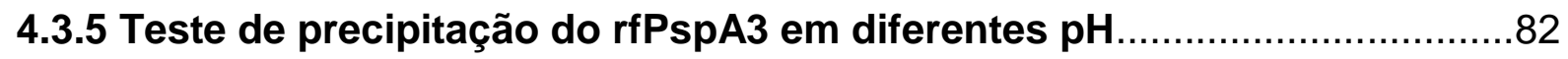

4.3.6 Testes de adsorção em resina Q-sepharose Fast-Flow.............................84

4.3.7 Testes em Colunas Cromatográficas .................................................... 89

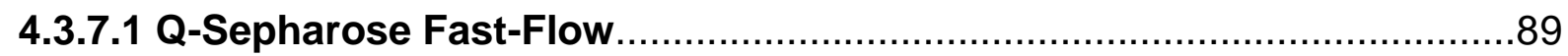

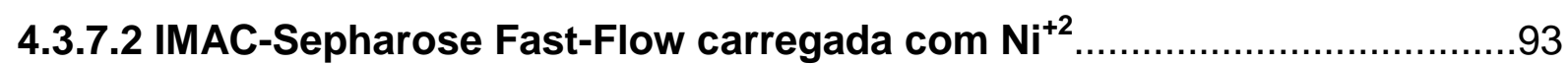

4.3.7.3 Estabelecimento da seqüência das cromatografias em Q-Sepharose e

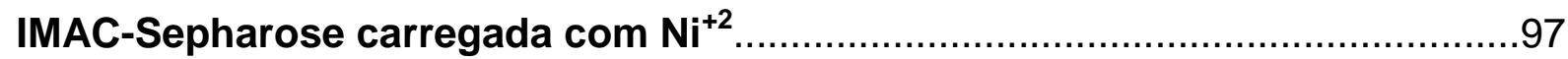

4.3.8 Estudos para estabelecer a terceira etapa de purificação......................101

4.3.8.1 Sephacryl S-200 HR como possível terceira etapa cromatográfica......102

4.3.8.2 Phenyl-Sepharose High Sub Fast Flow como possível terceira etapa

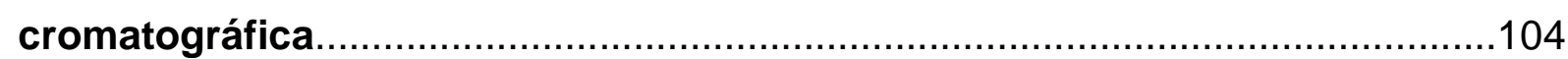

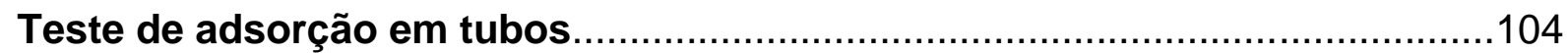

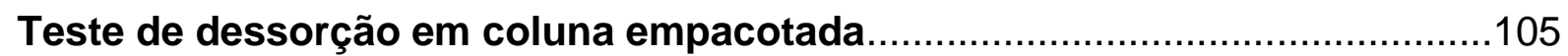

4.3.8.3 Recuperação de rfPspA3 por precipitação isoelétrica ...........................106

4.3.8.4 SP-Sepharose Fast Flow como possível terceira etapa

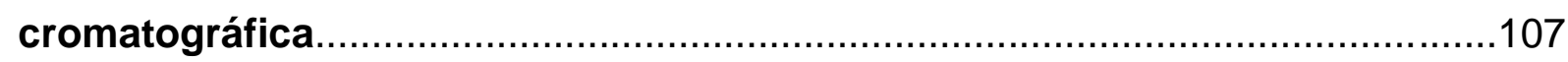

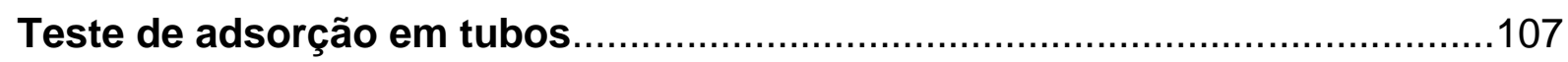

Teste de dessorção em coluna empacotada ..............................................110

4.4 COMPARAÇÃO ENTRE A PURIFICAÇÃO DO rfPspA3 OBTIDO EM CULTIVOS DE ALTA DENSIDADE COM GLICOSE E COM GLICEROL...............113

4.5 ANÁLISE ESTRUTURAL DO rfPspA3 PURIFICADO .................................121

4.6 PONTOS IMPORTANTES DURANTE O PROCESSO DE PURIFICAÇÃO.....122

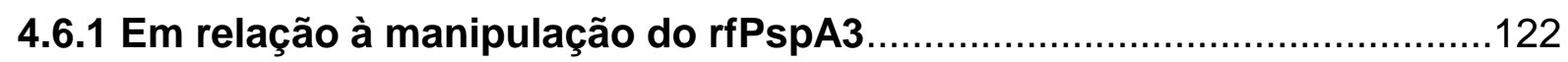

4.6.2 Em relação aos aspectos econômicos do processo...............................122

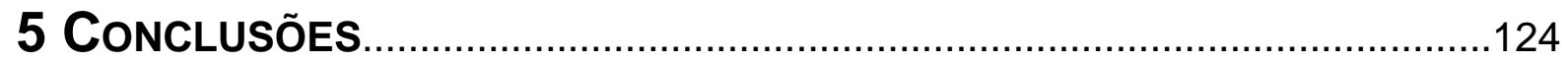

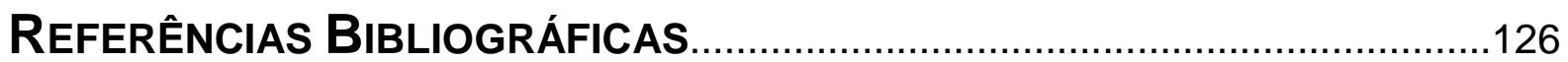

ANEXOS

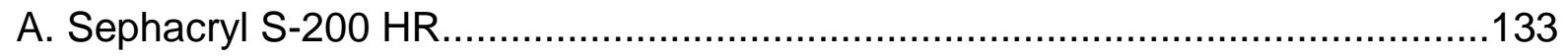

B. Phenyl-Sepharose 6 high sub Fast-Flow.......................................................134 


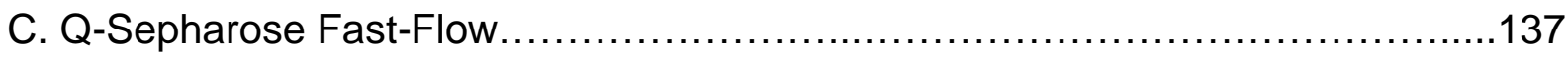

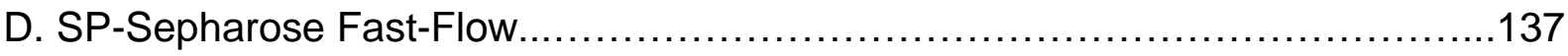

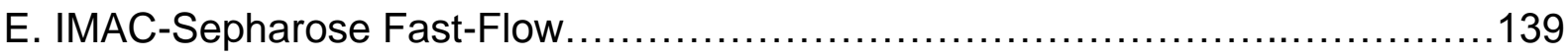




\section{INTRODUÇÃo}

Streptococcus pneumoniae é um importante patógeno humano responsável por infecções das vias respiratória superiores e inferiores, otite e meningite. A população mais vulnerável são crianças menores de 5 anos de idade (Figura 1.1), pessoas com mais de 60 anos e imunocomprometidos ${ }^{1}$.

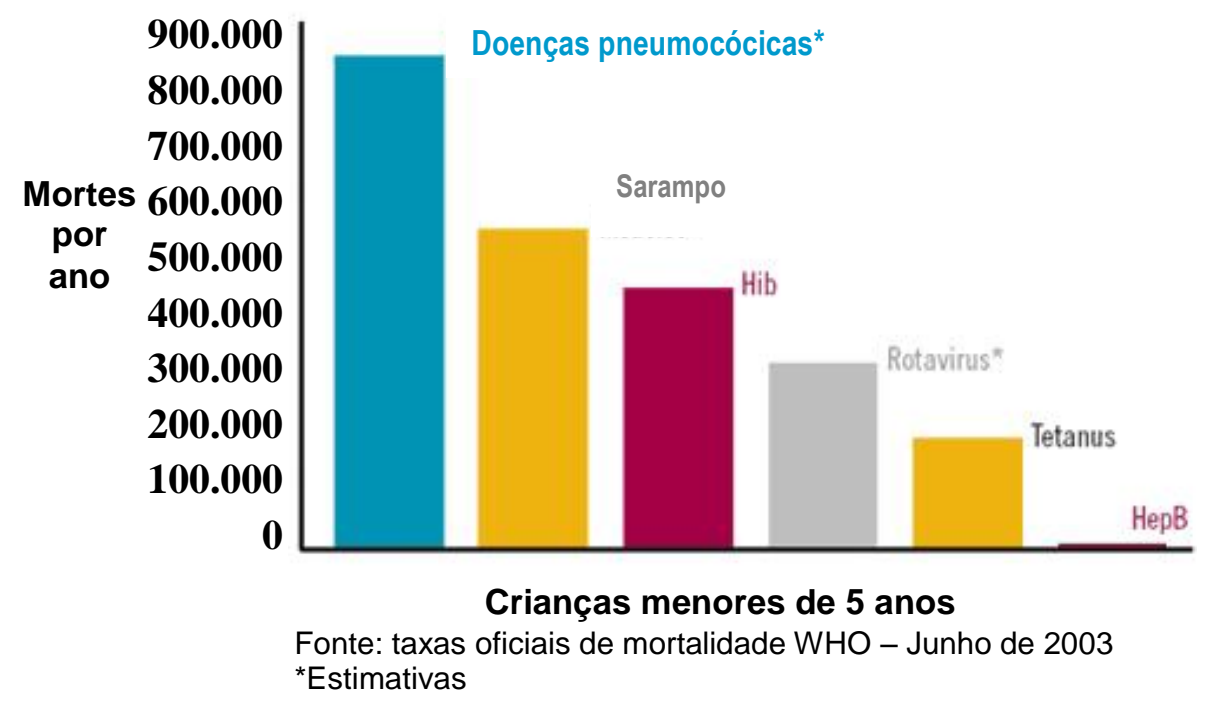

Figura 1.1: Taxa anual de mortalidade de crianças menores de 5 anos por doenças causadas por diferentes patógenos em todo o mundo, sendo que mais de 800.000 mortes são causadas somente por doenças pneumocócicas ${ }^{2}$.

Atualmente são identificados mais de 90 sorotipos diferentes de pneumococo, cada um correspondendo a uma composição química diferente do polissacarídeo (PS) da cápsula e aproximadamente 20 sorotipos desse total são responsáveis pela infecção grave ${ }^{1}$. A prevalência desses sorotipos varia conforme a região geográfica, com a idade da população e ao longo do tempo. No Brasil, 13 sorotipos são responsáveis por $75 \%$ dos casos da doença invasiva, sendo $1 / 3$ do total de casos provocado pelos sorotipos 1, 6B e 14. A distribuição se altera com a idade e o sorotipo 3 passa a ser prevalente entre a população de $15-60$ anos $(9,3 \%$ dos casos) e maior de 60 anos (14,6\% dos casos) ${ }^{3}$.

A administração de vacinas tem demonstrado boa eficácia na prevenção da infecção pneumocócica, desde que a composição agregue os sorotipos prevalentes em cada região geográfica. Por exemplo, a vacina composta por 23 polissacarídeos provenientes de 23 sorotipos prevalentes nos EUA e na Europa apresenta cobertura de $90 \%$ dos casos da doença nessas duas regiões, entretanto de apenas $70 \%$ na Ásia $^{4}$. O principal problema desta vacina multi-polissacarídica é que PS são 
antígenos independentes de células $\mathrm{T}$, por isso não protegem as crianças menores de 2 anos. Uma alternativa para melhorar a resposta imune de vacinas polissacarídicas é a conjugação dos PS com uma proteína carregadora. Atualmente, uma vacina antipneumocócica heptavalente conjugada ao toxóide diftérico tem sido comercializada. Esta vacina tem apresentado proteção em crianças, mas somente contra os sorotipos presentes na vacina. Embora seja eficiente, essa vacina é muito cara, o que inviabiliza sua introdução na campanha nacional de vacinação infantil, sendo necessário aplicar três doses para assegurar a proteção ${ }^{5}$.

Para contornar os problemas supracitados, estudos mais recentes têm sugerido que certas proteínas de superfície poderiam ser testadas como vacinas, pois esses antígenos ofereceriam maior proteção, seriam comuns a um maior número de cepas e poderiam ser usados individualmente ou em combinação com outros antígenos protéicos. Essas proteínas estão envolvidas nas interações diretas com o hospedeiro ou protegem a superfície da bactéria dos mecanismos de defesa do hospedeiro ${ }^{6}$.

A estratégia adotada pelo Centro de Biotecnologia do Instituto Butantan para o desenvolvimento de uma nova vacina antipneumocócica envolve a conjugação de alguns PS de sorotipos prevalentes no Brasil com proteínas recombinantes do próprio pneumococo. A conjugação, isto é, ligação covalente do PS a uma proteína, como explicado acima, converte a resposta imune contra PS em timo-dependente, permitindo assim o desenvolvimento de memória imunológica contra esse antígeno. Desse modo, uma vacina conjugada antipneumocócica mais barata e simples seria obtida, pois ela seria composta por menor número de PS e apresentaria maior espectro de ação dado pela porção protéica da vacina. A primeira escolha do Centro de Biotecnologia foi a PspA (Pneumococal surface protein A). A presença desta proteína na superfície é considerada indispensável para a virulência do pneumococo. Estudos em camundongos têm demonstrado que esta proteína possui a capacidade de reduzir a ação mediada por complemento e a fagocitose das células de pneumococos. A imunização com PspA apresenta ainda a capacidade de induzir proteção ativa e passiva mediadas respectivamente por anticorpos e soros hiperimunes e/ou anticorpos monoclonais ${ }^{7,6}$.

Baseado na identidade e no alinhamento das seqüências de aminoácidos de PspA de diferentes cepas de $S$. pneumoniae, foram observadas 3 famílias distintas, divididas em 6 grupos denominados clados: família 1 constituída de dois clados (1 e 
2); família 2 constituída de três clados (3, 4 e 5); família 3 com apenas um clado (6). Dentro de uma mesma família ocorre o reconhecimento dos diferentes clados por anticorpos anti-PspA de forma cruzada. A grande maioria dos S. pneumoniae isolados de pacientes são classificados como pertencentes às famílias 1 e 2 , ambas com $\sim 50 \%$ dos casos, contando a família 3 com apenas $\sim 1 \%$ dos casos. A imunização passiva realizada em camundongos com anticorpos anti-PspA, ou a imunização ativa com PspA, tem apresentado um bom nível de proteção após desafio subseqüente com pneumococos de diferentes sorotipos ${ }^{6}$. PspA é a única proteína pneumocócica que tem mostrado resposta de proteção contra cepas virulentas de pneumococos em camundongos desafiados com o correspondente a 100 vezes a dose letal (DL 50).

Os fragmentos do gene da PspA normalmente inseridos em vetores para expressão heteróloga não possuem a informação da proteína inteira, ou seja, eles não possuem a cauda de colina (Figura 1.2). Essa cauda fica ancorada na parede celular do $S$. pneumoniae e por não estar exposta na superfície do microrganismo (Figura 1.3) ela não está acessível ao reconhecimento pelos anticorpos, não sendo então necessária para a produção da resposta imune $\mathrm{i}^{9,10}$.

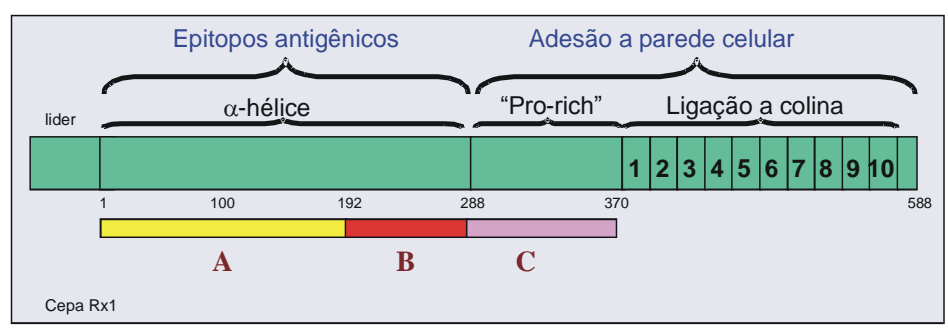

Figura 1.2: Estrutura da PspA, a barra estreita indica os fragmentos fPspA 1 e 3 clonados no Centro de Biotecnologia do Instituto Butantan ${ }^{11}$. 


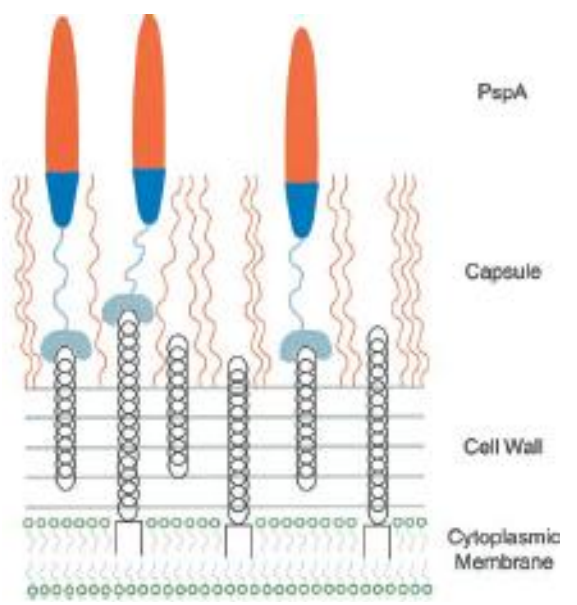

Figura 1.3: Esquema da estrutura da parede celular do pneumococo e do ancoramento da PspA. A parte vermelha da proteína possui carga eletronegativa e a parte azul eletropositiva ${ }^{12}$.

A obtenção e purificação do fragmento da PspA clado 3 (PspA3) permitirá uma nova candidata à vacina de subunidades antipneumocócica com cobertura de $\sim 50 \%$ em termos de PspA e que juntamente com a PspA clado 1 (PspA1) abrangeria quase $100 \%$ de cobertura para as linhagens da família 1 e 2 .

Para a produção de vacinas compostas de proteínas recombinantes há duas principais etapas do processo: a produção de células (cultivo) e, posteriormente, a purificação da proteína de interesse obtida pelo cultivo das células. Procura-se desenvolver um processo simples e eficiente visando obter um maior rendimento do produto de interesse com um menor custo. Apesar de vários estudos tratarem separadamente da produção (cultivo) e da purificação de proteínas recombinantes, estas etapas estão intimamente ligadas, uma vez que há diversos tipos de cultivo, com alta ou baixa densidade celular, e que múltiplos fatores irão interferir diretamente na purificação ${ }^{13}$.

\subsection{CULTIVO}

O principal objetivo das pesquisas em cultivo de microrganismos, não apenas para produção de vacinas, é maximizar a produtividade volumétrica, ou seja, a quantidade de produto por unidade de volume e por unidade de tempo $(\mathrm{g} / \mathrm{L} . \mathrm{h})^{14}$. A produtividade volumétrica total é o produto da produtividade especifica (g produto/g biomassa.h) pela concentração final da biomassa (g biomassa/L). Vários fatores influenciam essas variáveis como: a linhagem bacteriana, modificações genéticas, 
escolha de promotores adequados quando se tratam de microrganismos recombinantes, indutores e condições do cultivo.

O estudo de todos esses fatores que englobam desde as etapas de biologia molecular até a engenharia bioquímica tem como finalidade reduzir o consumo de meios de cultura, de insumos e de energia, minimizando assim a geração de resíduos e facilitando os processos de purificação. Paralelamente, busca-se também diminuir o impacto do capital fixo, otimizando as dimensões dos equipamentos utilizados. A obtenção destes parâmetros é conseqüência de um processo com uma produção elevada, altos rendimentos do produto de interesse e menor geração de subprodutos que possam inibir a produção celular, objetivo dos cultivos em alta densidade celular ${ }^{15}$.

E. coli é o procarioto mais utilizado para a síntese de proteínas heterólogas por possuir um sistema bem caracterizado ${ }^{16}$ e possibilitar seu crescimento em altas densidades celulares ${ }^{15,16}$. Diversos trabalhos demonstram a eficiência da produção de proteínas recombinantes ao utilizar esse microrganismo como sistema de expressão em relação a outros sistemas, como no caso da produção de uma vacina contra a malária ${ }^{17}$. Uma proteína sintetizada para esta vacina com 21 epítopos apresentou baixo rendimento no sistema de expressão em baculovirus $(0,1$ $1,0 \mathrm{~g} / \mathrm{L})^{18}$, porém, em $E$. coli obteve-se 3 vezes mais proteína ${ }^{19}$.

Visando a obtenção de proteínas recombinantes e outros produtos em cultivos de alta densidade dois principais problemas devem ser evitados: 1) inibição por substrato, tais como glicose (50 g/L), amônia (3 g/L), ferro (1,15 g/L) e 2) inibição por subprodutos metabólicos como acetato, propionato, lactato, etanol, etc ${ }^{20}$.

Para evitar a inibição por substrato e a formação de metabólitos ácidos, os cultivos são realizados em meios definidos ou semi-definidos, com concentrações dos substratos inferiores às inibitórias e, especialmente, controlando a concentração da fonte de carbono ${ }^{14,21}$. Para alcançar essas condições em geral são utilizados cultivos descontínuos alimentados, também chamados de bateladas alimentadas, havendo inúmeras estratégias de alimentação. No caso de $E$. coli recombinante, os cultivos são feitos em basicamente três fases: 1) cultivo descontínuo ou fase batelada - até que a fonte de carbono inicialmente adicionada ao meio seja consumida, com $\mu=\mu_{\max }$ (velocidade especifica de crescimento, $\mathrm{h}^{-1}$ ); 2) alimentação da fonte de carbono de forma controlada para evitar o acúmulo de acetato, com 
$\mu<\mu_{\max }$; e 3) adição do agente indutor para a síntese da proteína recombinante, com $\mu<<\mu_{\max }$, fase essa que representa um estresse metabólico ${ }^{22,23}$.

As estratégias de alimentação mais empregadas são: 1) alimentação constante, $\mu$ decrescente, 2) alimentação linear, $\mu$ compensado (crescente e decrescente) e 3) alimentação exponencial, $\mu_{\text {set }}<\mu_{\text {crítico }}<\mu_{\max }$, 4) alimentação através do controle da concentração de oxigênio dissolvido (DO-stat) ou do pH (pHstat). Todas estas estratégias buscam manter substrato limitante em uma concentração suficiente para o crescimento bacteriano evitando que ocorra a formação de subprodutos inibidores ${ }^{15}$.

Além disso, quando se objetiva a produção de proteína recombinante intracelular em E. coli, a fase de indução é parte fundamental que pode determinar maior ou menor produtividade, dependendo de fatores como a concentração do indutor e a razão indutor/células ${ }^{24}$. Em laboratório, normalmente utiliza-se o Isopropil- $\beta$-D-tiogalactopiranosídeo (IPTG) como indutor para as construções derivadas do operon da lactose (Figura 1.4). Porém, se por um lado ele é um análogo estrutural que não é consumido durante o processo e independe de transportador para entrar nas células, por outro lado o IPTG apresenta duas desvantagens para um processo industrial: é caro e tóxico. A alternativa ao uso do IPTG é a própria lactose, que por sua vez apresenta a desvantagem de ser consumida durante o processo e depender da presença da permease na superfície das bactérias ${ }^{25}$. 

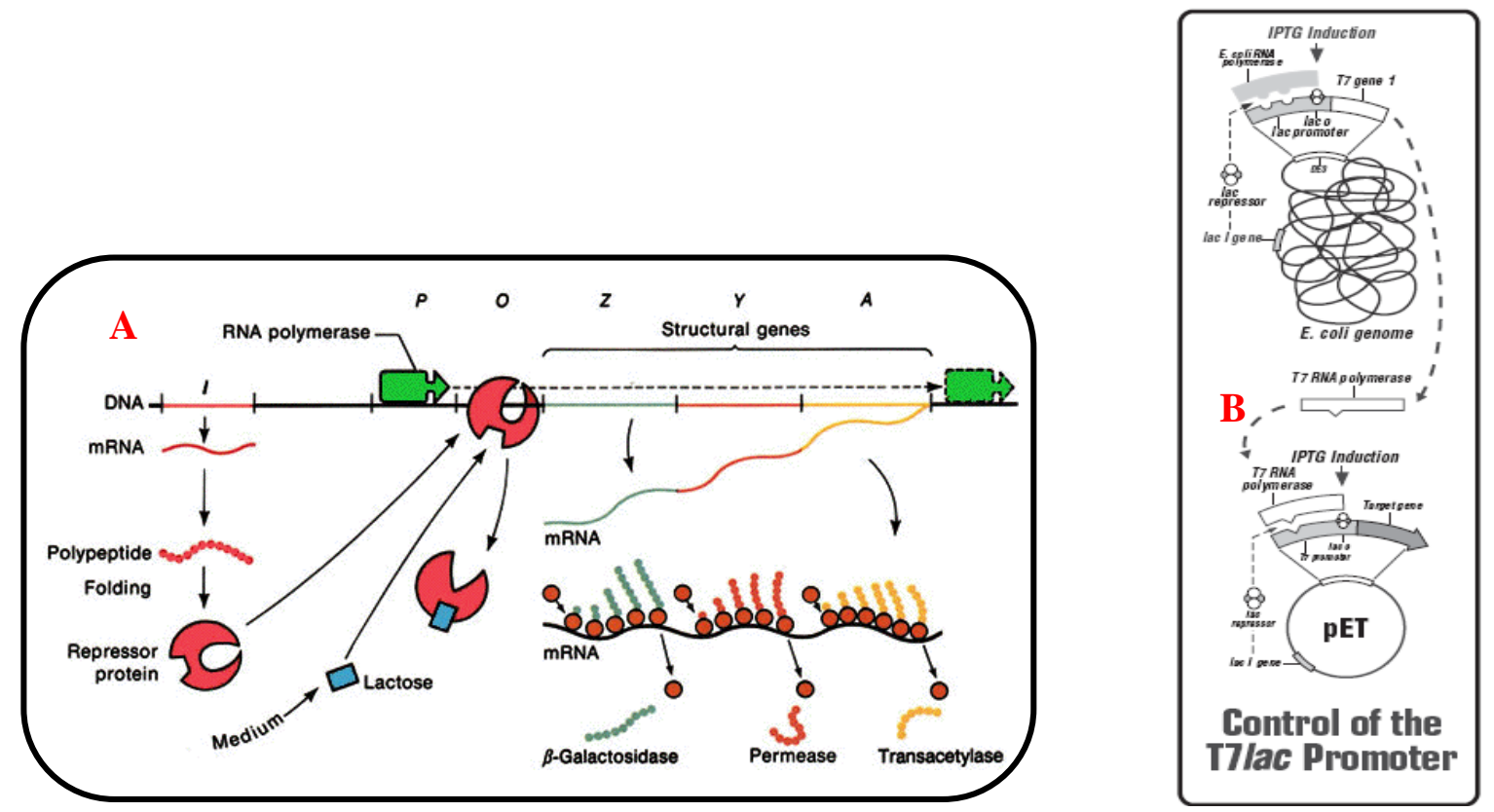

Figura 1.4: Sistema de controle do operon Lac. A) no cromossomo da bactéria com a produção de permease $^{26}$; B) no sistema $\mathrm{pET}$ com a indução da expressão do gene de interesse presente no vetor ${ }^{27}$.

\subsection{PURIFICAÇÃO}

A purificação, também chamada de "downstream processing", acontece logo após a obtenção do "produto bruto", o qual é processado até obter-se o grau de pureza requerido para o seu uso, buscando-se maximizar sua recuperação e minimizar seu custo. Além da pureza relativa, os produtos biotecnológicos apresentam requerimentos em relação à quantidade de impurezas como ácidos nucléicos, pirógenos, limites relativos à "cor", ausência de atividades enzimáticas nocivas ao produto e ao seu uso (ex: proteases, atividade hemolítica). Caso o produto apresente similar, estas normas são fornecidas pelo FDA, OMS e/ou pelas farmacopéias. O custo da purificação de um produto biotecnológico varia entre 20 a $80 \%$ do total do processo ${ }^{28}$.

As estratégias para desenvolvimento de processos de purificação baseiamse nas diferenças entre as propriedades físico-químicas do produto de nosso interesse e as das impurezas, diferenças como: localização (intra ou extracelular), massa molecular, carga elétrica, hidrofobicidade, solubilidade, afinidade por ligantes específicos. O processo de purificação das proteínas para uso farmacêutico deve ter no mínimo duas etapas, baseadas em propriedades diferentes, sempre tendo em mente a possibilidade de os métodos usados serem facilmente amplificáveis e 
baratos, todos os materiais e os equipamentos devem apresentar estabilidade e resistência aos processos de limpeza e sanitização in situ ("CIP" cleaning in place e "SIP" sanitization in place) $)^{29}$.

Atualmente, a produção de proteínas recombinantes, principalmente para uso terapêutico, vem sendo extensivamente estudada ${ }^{30,31}$. Devido à exigência de um alto grau de pureza (acima de 95\%) e por ser geralmente um produto intracelular, há uma enorme gama de metodologias que podem ser utilizadas para a purificação de proteínas recombinantes na dependência da análise prévia das características físico-químicas da proteína de interesse, a escolha de um processo pode ser mais bem direcionada ${ }^{32,33}$.

Em linhas gerais, as etapas de purificação de uma proteína recombinante compreendem: a) separação das células do meio de cultura por centrifugação convencional ou contínua, microfiltração tangencial ou convencional; b) extração das proteínas intracelulares através da desintegração das bactérias por homogeneizador contínuo de alta pressão ou lise química; c) clarificação do homogenato, eliminação de material particulado e insolúvel por centrifugação ou filtração convencional/tangencial ou cromatografias de leito expandido; d) purificação primária, nesta etapa são eliminadas as maiores quantidades das impurezas com propriedades físico-químicas que diferem significativamente das propriedades da molécula de interesse, precipitações e cromatografias de adsorção, como troca iônica, hidrofóbica e afinidade, que são as técnicas mais usadas; e) purificação de alta resolução, separação de impurezas com propriedades físico-químicas muito semelhantes às do produto, e para isso as técnicas normalmente utilizadas são precipitações seletivas, cromatografia de filtração em gel e cromatografia de afinidade $28,33,34$.

A cromatografia líquida é um método bastante utilizado na purificação de proteínas para uso farmacêutico, que requer um produto altamente puro (> 95\%). A investigação de características da proteína a ser purificada para definir a cromatografia a ser utilizada é essencial para se garantir alto rendimento do produto. A cromatografia de troca iônica é uma das mais utilizadas por ser de baixo custo e de fácil operação, ela baseia-se em interações eletrostáticas como princípio de separação $^{28,33}$.

A cromatografia por afinidade também é muito utilizada, apesar de ter custo mais elevado, ela é altamente específica levando a um alto fator de purificação. Um 
exemplo clássico desse tipo de cromatografia é a afinidade por metais realizada em resina quelante, utilizada para separar proteínas com cauda de histidina que apresentam alta afinidade por metais ${ }^{35}$.

A cromatografia de exclusão molecular, também chamada de filtração molecular ou permeação em gel, é a cromatografia mais tradicional, separando as moléculas pela sua massa molar. Desde a descoberta do gel de Sephadex, em 1959, essa cromatografia vem sendo extensivamente usada ${ }^{33}$.

Outro exemplo de cromatografia líquida é a de interação hidrofóbica. Nesta cromatografia a fase estacionária é formada por grupamentos apolares e as soluções protéicas quando em altas concentrações salinas expõem seus grupamentos hidrofóbicos, sendo assim adsorvidas pela resina ${ }^{33}$.

Portanto, diferentes estratégias de purificação podem ser montadas a partir da caracterização físico-química das proteínas em estudo. 


\section{OBjetivos}

\subsection{GERAL}

- Desenvolver um processo de produção e purificação de rfPspA3 em $E$. coli BL21(DE3) que seja economicamente viável e escalonável.

\subsection{ESPECÍFICOS}

- Aperfeiçoar o processo de produção em alta densidade de E. coli utilizando cultivo descontínuo alimentado e avaliar duas fontes de carbono, glicose e glicerol;

- Desenvolver um processo de purificação escalonável que gere uma relação custo-benefício viável em uma produção em alta escala, analisar a lise por processo mecânico, comparar etapas de clarificação por centrifugação, micro e utrafiltração tangencial e definir as condições de adsorção e dessorção das cromatografias de troca aniônica, afinidade, permeação em gel, hidrofóbica e troca catiônica e, posteriormente, a melhor seqüência das etapas cromatográficas escolhidas;

- Comparar a purificação de proteínas provenientes do cultivo em alta densidade com glicose e com glicerol como fonte de carbono, após a definição das etapas de purificação. 


\section{Materiais e Métodos}

\subsection{CONSTRUÇÃO DO VETOR}

A clonagem do gene $f p s p A 3$ foi realizada pela Dra. Eliane Miyaji, do Centro de Biotecnologia do Instituto Butantan, no vetor pET37b+ (Departament of Microbial Genetics, National Institute of Genetics Shizuoka-ken, Japan). Este vetor apresenta marca de resistência ao antibiótico kanamicina (kan), o promotor T7 (induzido por IPTG ou lactose), sítio de ligação ao ribossomo (RBS), códon ATG de início de tradução, cauda de 6 histidinas, sinal de terminação de transcrição "T7 terminal" e gene do repressor Lacl. A kanamicina tem a vantagem de ser aceita para a produção de biofármacos e não ser degradada no meio durante o cultivo. 


\subsection{ETAPAS DO PROCESSO DE PRODUÇÃO E PURIFICAÇÃO DO rfPspA3}

A seqüência do fragmento recombinante da PspA3 a ser produzido foi analisada através de um programa da rede mundial de Internet ${ }^{36}$ de fácil acesso, 0 qual forneceu todas as características do fragmento recombinante necessárias para o desenvolvimento deste trabalho como ponto isoelétrico (pl), número e composição de aminoácidos, massa molecular, entre outras usadas para traçar um planejamento de purificação.

Como mostra a Figura 3.1, em cada etapa foi feito um estudo para desenvolver um processo produtivo eficiente e econômico que seja viável em uma produção de maior escala.
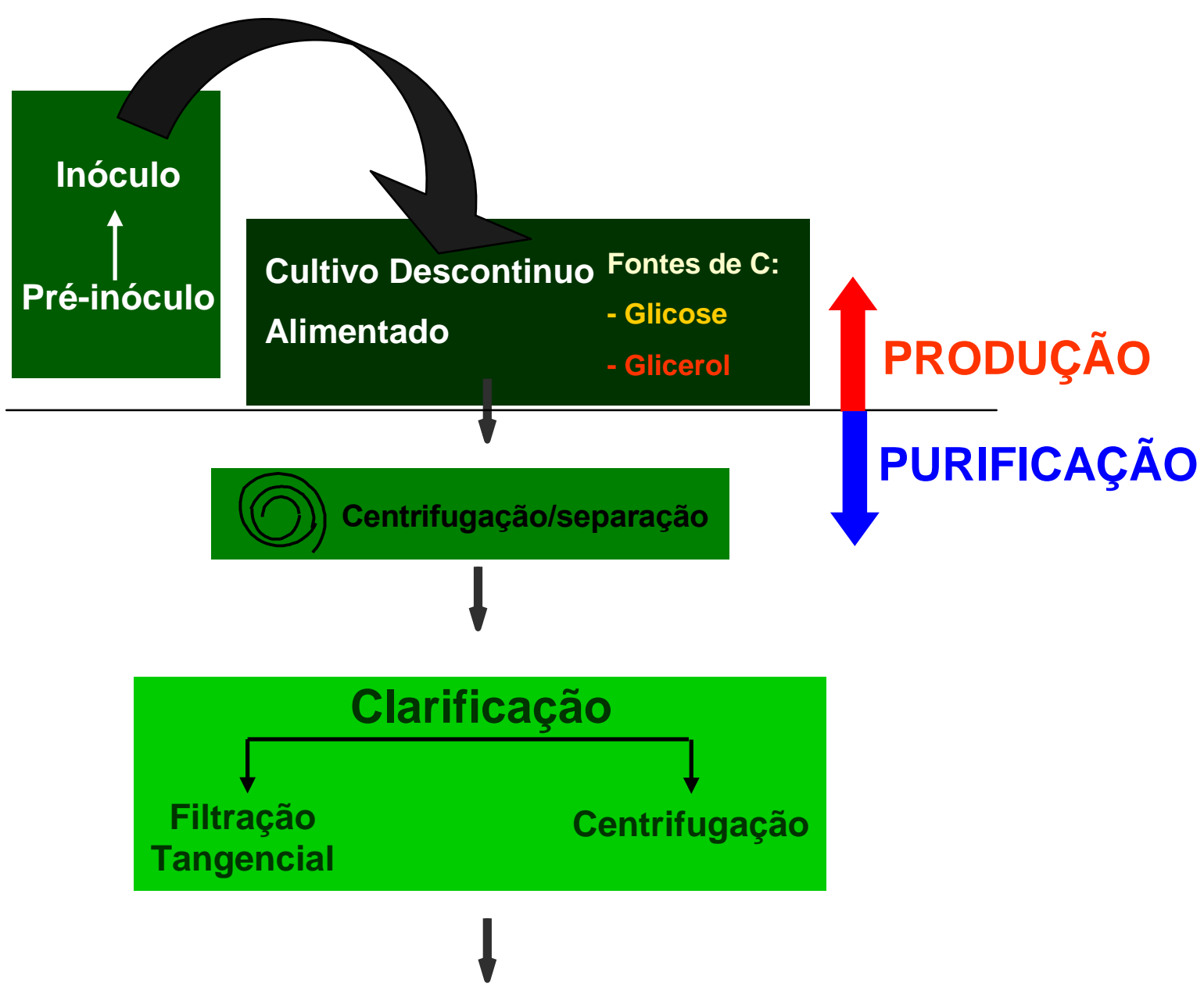

ETAPAS CROMATOGRÁFICAS

Definir a sequência de resinas

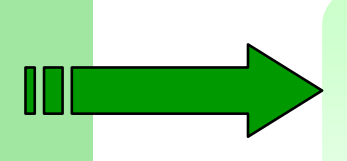

rfPspA3
Purificada

Figura 3.1: Etapas do processo de produção e purificação do fragmento recombinante da PspA3. 


\subsection{PRODUÇÃO DO fPspA3 EM E. coli BL21 (DE3) - UPSTREAM}

\subsubsection{Ensaios em frascos agitados}

A verificação da expressão do gene, a seleção do clone produtor e a avaliação da síntese da proteína de interesse em meio quimicamente definido foram realizados em frascos agitados.

Foram empregados dois meios: meio complexo Luria Bertani, LB (Tabela 3.1) e meio quimicamente definido para alta densidade celular ${ }^{37}$ (MQD - Tabela 3.2), ambos contendo $25 \mathrm{mg} / \mathrm{L}$ de kan.

Tabela 3.1: Composição do meio complexo LB.

\begin{tabular}{lc}
\hline Componentes & Concentração (g/L) \\
\hline Extrato de Levedura & 5,0 \\
Triptona & 10,0 \\
$\mathrm{NaCl}$ & 10,0 \\
\hline
\end{tabular}

Tabela 3.2: Composição do meio quimicamente definido (MQD) para ensaios em frascos.

\begin{tabular}{|c|c|}
\hline Componentes & Concentração \\
\hline$\left(\mathrm{NH}_{4}\right)_{2} \mathrm{HPO}_{4}$ & $4 \mathrm{~g} / \mathrm{L}$ \\
\hline $\mathrm{KH}_{2} \mathrm{PO}_{4}$ & $13,3 \mathrm{~g} / \mathrm{L}$ \\
\hline Ác. Cítrico. $\mathrm{H}_{2} \mathrm{O}$ & $1,7 \mathrm{~g} / \mathrm{L}$ \\
\hline $\mathrm{Fe}(\mathrm{III})$ citrato & $100,8 \mathrm{mg} / \mathrm{L}$ \\
\hline $\mathrm{COCl}_{2} \cdot 6 \mathrm{H}_{2} \mathrm{O}$ & $2,5 \mathrm{mg} / \mathrm{L}$ \\
\hline $\mathrm{MnCl}_{2} \cdot 4 \mathrm{H}_{2} \mathrm{O}$ & $15,0 \mathrm{mg} / \mathrm{L}$ \\
\hline $\mathrm{CuCl}_{2} \cdot 2 \mathrm{H}_{2} \mathrm{O}$ & $1,5 \mathrm{mg} / \mathrm{L}$ \\
\hline $\mathrm{H}_{3} \mathrm{BO}_{3}$ & $3 \mathrm{mg} / \mathrm{L}$ \\
\hline $\mathrm{Na}_{2} \mathrm{MoO}_{4} \cdot 2 \mathrm{H}_{2} \mathrm{O}$ & $2,1 \mathrm{mg} / \mathrm{L}$ \\
\hline $\mathrm{Zn}\left(\mathrm{CH}_{3} \mathrm{COOH}\right)_{2} \cdot \mathrm{H}_{2} \mathrm{O}$ & $33,8 \mathrm{mg} / \mathrm{L}$ \\
\hline $\mathrm{HCl} 6 \mathrm{~N}$ & $4,15 \mathrm{~mL}$ \\
\hline EDTA & $14,1 \mathrm{mg} / \mathrm{L}$ \\
\hline $\mathrm{MgSO}_{4 .} \cdot 7 \mathrm{H}_{2} \mathrm{O}$ & $1,2 \mathrm{~g} / \mathrm{L}$ \\
\hline Tiamina & $4,5 \mathrm{mg} / \mathrm{mL}$ \\
\hline $\begin{array}{l}\text { Kanamicina } \\
\mathrm{pH}\end{array}$ & $\begin{array}{c}25 \mathrm{mg} / \mathrm{mL} \\
6,3\end{array}$ \\
\hline Fonte de Glicose & $10,0 \mathrm{~g} / \mathrm{L}$ \\
\hline Carbono* Glicerol & $20,0 \mathrm{~g} / \mathrm{L}$ \\
\hline
\end{tabular}


Os cultivos foram realizados em Erlenmeyers de $300 \mathrm{~mL}$ com $30 \mathrm{~mL}$ de meio. Uma colônia foi isolada de uma placa de LBkan/ágar e semeada em meio líquido. Foi utilizado o agitador orbital (Innova 44, New Brunswick) para controlar a agitação e a temperatura do meio em $200 \mathrm{rpm}$ e $30^{\circ} \mathrm{C}$, respectivamente. A indução foi realizada quando se obteve uma densidade ótica a 600nm ( $\left(\mathrm{DO}_{600 \mathrm{~nm}}\right)$ de aproximadamente 1,0 pela adição $1,0 \mathrm{mM}$ de isopropil- $\beta$-D-tiogalactopiranosídeo (IPTG) e o cultivo prosseguiu por mais 4 horas. Amostras de $2 \mathrm{~mL}$ foram retiradas de hora em hora e utilizadas nas análises de crescimento celular pela turbidez em DO $600 \mathrm{~nm}$, estabilidade do plasmídeo pela porcentagem de colônias obtidas resistentes à kanamicina e síntese da proteína de interesse averiguada por eletroforese SDS-PAGE (métodos descritos no tópico 3.5).

\subsubsection{Preparo do estoque congelado}

Após o teste de expressão do gene foi feito um estoque de células da colônia escolhida. A produção de células estoque foi realizada nas condições descritas no item 3.3.1 com meio MQD e glicose como fonte de carbono. Como crioprotetor foi adicionado ao meio $30 \% \mathrm{v} / \mathrm{v}$ de glicerol. As células foram estocadas à $-80^{\circ} \mathrm{C}$.

\subsubsection{Preparo de inóculo}

Antes do cultivo em biorreator, foram preparadas duas etapas de crescimento celular em frascos agitados chamadas de pré-inóculo e inóculo. Essas etapas foram feitas utilizando meio MQD com a mesma fonte de carbono utilizada nos biorreatores.

O cultivo do pré-inóculo foi realizado em um volume total de $10 \mathrm{~mL}$ em frascos de $100 \mathrm{~mL}$ com inoculação de uma colônia obtida de placas LBkan/ágar que foram estriadas com a suspensão de células do estoque congelado e incubadas por 24 horas à $37^{\circ} \mathrm{C}$. Posteriormente, após o crescimento até $\sim 1,2 \mathrm{~g}$ de massa seca/L, uma alíquota de $2 \mathrm{~mL}$ do pré-inóculo foi transferida para um frasco de $2000 \mathrm{~mL}$ com $200 \mathrm{~mL}$ do mesmo meio e a cultura foi incubada à $37^{\circ} \mathrm{C}$ até que se obtivesse uma concentração celular entre 1,2 e 2,0 g de massa seca/L. Foi utilizado o agitador orbital (Innova 44, New Brunswick) para controlar a agitação do pré-inóculo e inóculo 
em 200 rpm. Os cultivos em reator foram inoculados com um volume de inoculo suficiente para se obter $\sim 0,04 \mathrm{~g}$ de massa seca/L $\left(\mathrm{DO}_{600 \mathrm{~nm}} \sim 0,1\right)$.

\subsubsection{Cultivo em biorreator}

\subsubsection{Descontínuo}

O meio de cultura quimicamente definido (MQD) foi empregado para os ensaios em biorreator de 5,0 litros Bioflo 2000 (New Brunswick), onde os cultivos tiveram controle automático de $\mathrm{pH}$ em $6,7^{37}$ pela adição de hidróxido de amônio $24 \% \mathrm{v} / \mathrm{v}$, controle automático da concentração de oxigênio dissolvido em $30 \%{ }^{37}$ da saturação pelo aumento da agitação e pela adição de oxigênio puro ao gás de entrada quando necessário. Como antiespumante foi empregado polipropilenoglicol (PPG). Os parâmetros cinéticos foram calculados graficamente através dos dados obtidos (item 3.5.1).

Após o total consumo da fonte de carbono, que foi identificado pelo aumento abrupto da concentração de $\mathrm{O}_{2}$ no reator, a indução foi realizada pela adição de $0,1 \mathrm{mM}$ de IPTG, seguida de $20 \mathrm{~g} / \mathrm{L}$ de lactose ${ }^{25}$.

Assim como em frascos agitados, foram feitas as análises da produção de proteína por SDS-PAGE, além dos carboidratos e metabólitos ácidos que foram determinados por cromatografia líquida de alta eficiência (HPLC), métodos descritos no tópico 3.5 .

\subsubsection{Descontínuo Alimentado}

Obtidos os dados da cinética do cultivo descontínuo, foram feitos cultivos utilizando a estratégia de alimentação exponencial da fonte de carbono para se obter alta densidade celular. Para isso utilizou-se como primeira etapa a fase descontínua e após o total consumo da fonte de carbono iniciou-se a alimentação do biorreator segundo a Equação $3.1^{37}$ e o controle do $\mathrm{pH}$ foi ajustado para $6,9^{37}$. 


$$
m_{S}(t)=\left[\frac{1}{Y_{X / S}} \cdot \mu_{s e t}+m\right] \cdot V_{0} \cdot X_{0} \cdot e^{\mu_{s e t} \cdot\left(t-t_{0}\right)}
$$

Em que: $m_{\mathrm{S}}(t)=$ Fluxo mássico de alimentação de substrato em função do tempo $(\mathrm{g} / \mathrm{h})$; $\mathrm{V}_{0}=$ volume do reator no início da alimentação $(\mathrm{L}) ; \mathrm{X}_{0}=$ concentração celular no início da alimentação;

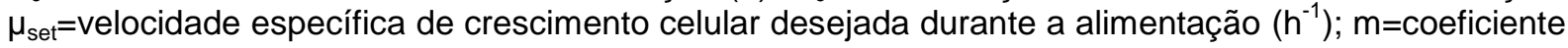
de manutenção celular $(0,025 \mathrm{~g} / \mathrm{g} . \mathrm{h}) ; \mathrm{Y}_{\mathrm{x} / \mathrm{s}}=$ fator de conversão de substrato em células ( $\mathrm{g}$ massa seca/g substrato); $t=$ tempo em um dado instante ( $h$ ) e $t_{0}=$ tempo no início da alimentação ( $h$ ).

Assim como no cultivo descontínuo, o meio de cultura utilizado também foi o MQD, com volume inicial de 3,5 L para que após a alimentação e a indução se atinja um volume final < $5 \mathrm{~L}$. A indução foi realizada em um período de $4 \mathrm{~h}$ pela adição de 0,5 mM de IPTG e $20 \mathrm{~g} / \mathrm{L}$ de lactose. A Tabela 3.3 apresenta a composição do meio de alimentação.

Tabela 3.3: Composição do meio de alimentação para os cultivos descontínuos alimentados ${ }^{37}$.

\begin{tabular}{|c|c|}
\hline Componentes & Concentração \\
\hline $\mathrm{Fe}(\mathrm{III})$ citrato & $40,0 \mathrm{mg} / \mathrm{L}$ \\
\hline $\mathrm{CoCl}_{2} \cdot 6 \mathrm{H}_{2} \mathrm{O}$ & $4,0 \mathrm{mg} / \mathrm{L}$ \\
\hline $\mathrm{MnCl}_{2} \cdot 4 \mathrm{H}_{2} \mathrm{O}$ & $23,5 \mathrm{mg} / \mathrm{L}$ \\
\hline $\mathrm{CuCl}_{2} \cdot 2 \mathrm{H}_{2} \mathrm{O}$ & $2,3 \mathrm{mg} / \mathrm{L}$ \\
\hline $\mathrm{H}_{3} \mathrm{BO}_{3}$ & $4,7 \mathrm{mg} / \mathrm{L}$ \\
\hline $\mathrm{Na}_{2} \mathrm{MoO}_{4} \cdot 2 \mathrm{H}_{2} \mathrm{O}$ & $4,0 \mathrm{mg} / \mathrm{L}$ \\
\hline $\mathrm{Zn}\left(\mathrm{CH}_{3} \mathrm{COOH}\right)_{2} \cdot \mathrm{H}_{2} \mathrm{O}$ & $16,0 \mathrm{mg} / \mathrm{L}$ \\
\hline $\mathrm{HCl} 6 \mathrm{~N}$ & $4,15 \mathrm{~mL}$ \\
\hline EDTA & $13,0 \mathrm{mg} / \mathrm{L}$ \\
\hline $\mathrm{MgSO}_{4} \cdot 7 \mathrm{H}_{2} \mathrm{O}$ & $20,0 \mathrm{~g} / \mathrm{L}$ \\
\hline Tiamina & $4,5 \mathrm{mg} / \mathrm{mL}$ \\
\hline Kanamicina & $25 \mathrm{mg} / \mathrm{mL}$ \\
\hline Fonte de Glicose & $600,0 \mathrm{~g} / \mathrm{L}$ \\
\hline Carbono* Glicerol & $696,0 \mathrm{~g} / \mathrm{L}$ \\
\hline
\end{tabular}

\subsubsection{Estudo da relação IPTG/ células/ tempo de indução}

Para definir a relação IPTG/ células/ tempo de indução que levasse a maior produção de rfPspA3 em cultivo de alta densidade celular foram propostos dois testes, um variando a concentração celular com a concentração de IPTG fixa em 1,0 $\mathrm{mM}$ e outro variando a concentração de IPTG com a concentração celular 
fixa em $56 \mathrm{~g} / \mathrm{L}$. Nos dois testes foram analisadas amostras de 4 e 12 horas de indução. Os testes foram feitos em frascos agitados de $300 \mathrm{~mL}$ com $24 \mathrm{~mL}$ de meio a $30^{\circ} \mathrm{C}$ e $250 \mathrm{rpm}$.

\section{- Variação da concentração celular (concentração fixa de IPTG)}

Foram retirados do reator $48 \mathrm{~mL}$ da suspensão celular antes da indução ( $D_{600 n m} \sim 140$ ), as células foram centrifugadas e ressuspensas em meio MQD contendo $16 \mathrm{~g} / \mathrm{L}$ de lactose e 1,0 mM de IPTG. Foram feitas diluições seriadas da suspensão celular obtida utilizando meio $2 x$ concentrado, resultando em suspensões com os seguintes valores de $\mathrm{DO}_{600 \mathrm{~nm}}: 140 ; 70 ; 35 ; 17,5$ e 8,75 .

A análise da produção de rfPspA3 em cada condição foi feita a partir da densitometria das bandas obtidas em eletroforese SDS-PAGE, empregando-se duas formas de aplicação das amostras de 4 e $12 \mathrm{~h}$ de indução: 1) $\mathrm{DO}_{600 \mathrm{~nm}}$ fixada em 5,0 e 2) volume fixo da suspensão celular $(2 \mu \mathrm{L})$.

\section{- Variação da concentração de IPTG (concentração celular fixa)}

Foram adicionados aos frascos $6 \mathrm{~mL}$ de meio MQD contendo $80 \mathrm{~g} / \mathrm{L}$ de lactose, posteriormente foi adicionado $18 \mathrm{~mL}$ do meio do cultivo com $\mathrm{DO}_{600 \mathrm{~nm}}$ a 140 resultando em uma concentração final de $16 \mathrm{~g} / \mathrm{L}$ de lactose e $D^{600 n m}$ igual a 105 . A suspensão obtida foi dividida em 6 amostras às quais foram adicionadas as seguintes concentrações de IPTG: 0; 0,5; 1,0; 1,5; 2,0; 2,5 mM. A produção de rfPspA3 foi avaliada após 4 e 12h de indução.

As análises foram feitas a partir da densitometria das bandas obtidas em eletroforese SDS-PAGE aplicando-se uma quantidade de células correspondente a $\mathrm{DO}_{600 \mathrm{~nm}}$ igual 5,0 das amostras. 


\subsection{ETAPAS DE PURIFICAÇÃO PROTÉICA - DOWNSTREAM}

\subsubsection{Separação celular do meio fermentado}

Após o cultivo, a suspensão celular obtida foi centrifugada a uma velocidade de $17.969 \mathrm{~g}$ por 30 min a $4{ }^{\circ} \mathrm{C}$ para a separação das células do meio fermentado. A massa celular foi congelada e o meio descartado, pois se trata de uma proteína solúvel intracelular.

\subsubsection{Lise Celular}

Em uma relação de $100 \mathrm{~g}$ de massa celular úmida para 1,0 $\mathrm{L}$ de tampão, as células foram ressuspensas em tampão de lise (25 mM Tris pH 8,0 + 0,1\% de Triton $\mathrm{X}-100$ ) com 1,0 mM de Fenilmetanosulfonilfluorídrico (PMSF - inibidor de protease). Para ajuste do pH do tampão de lise para 8,0, quando necessário, utilizou-se ácido acético glacial. Obteve-se uma suspensão homogênea em um mixer (CAT X520), que foi posteriormente lisada em um homogeneizador contínuo de alta pressão APVGauling 60 (Figura 3.2) em 10 ciclos de 1 minuto a 600 bar de pressão. A temperatura da suspensão foi controlada para que não ultrapasse $30^{\circ} \mathrm{C}$, obtendo-se assim o homogenato bruto.

A lise foi realizada com amostras provenientes dos cultivos em alta densidade com glicose e com glicerol como fontes de carbono. Em cada uma destas amostras foram realizadas 3 diferentes análises durante o processo de lise. Duas análises foram feitas para acompanhar a integridade das células: leitura da $\mathrm{DO}_{600 \mathrm{~nm}} \mathrm{em}$ espectrofotômetro Hitachi U-1800 e plaqueamento da amostra em meio LB/ágar com Kanamicina para leitura das Unidades Formadoras de Colônias (UFC/mL). Para definir o tempo necessário para liberação completa da rfPspA3, foi determinada a concentração de proteínas totais e rfPspA3 através da densitometria dos géis de eletroforese SDS-PAGE. Amostras foram recolhidas a cada minuto, durante 10 minutos, sendo o tempo inicial considerado após a obtenção da suspensão homogênea no mixer. Para a análise protéica, foi recolhido $1 \mathrm{~mL}$ da suspensão bacteriana, centrifugado por 60 minutos à $20817 \mathrm{~g}$. O sobrenadante foi separado do precipitado e utilizado para a quantificação protéica e para a eletroforese SDS-PAGE 
com $10 \mu \mathrm{g}$ de proteínas totais. Posteriormente, foi determinada a concentração de rfPspA3 por densitometria dos géis de eletroforese obtidos.

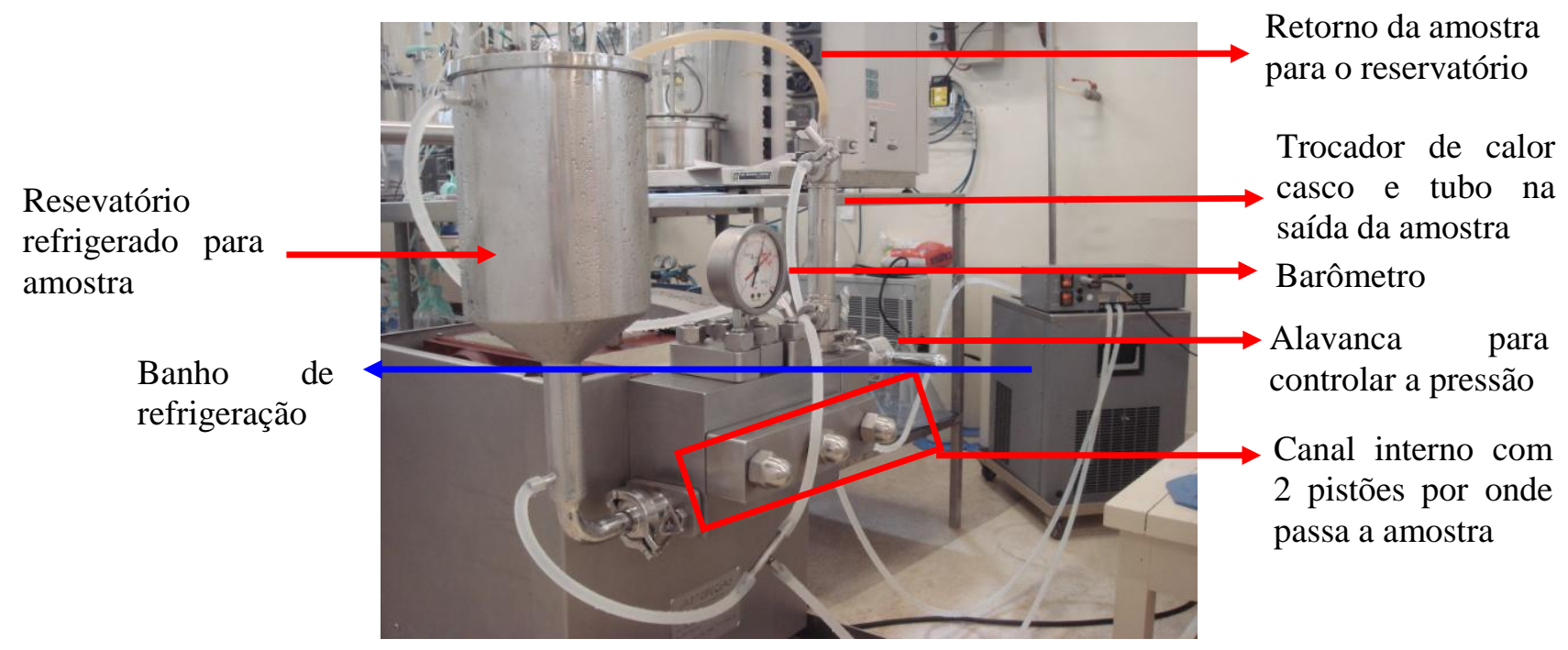

Figura 3.2: Homogeneizador contínuo de alta pressão APV-Gauling utilizado para lise celular de $E$. coli.

\subsubsection{Teste de Solubilidade do rfPspA3}

Após a lise celular, $1,0 \mathrm{~mL}$ do homogenato bruto foi centrifugado à $20.817 \mathrm{~g}$ por 60 min à $4{ }^{\circ} \mathrm{C}$. As amostras do pellet e sobrenadante foram analisadas por SDSPAGE. O pellet foi ressuspendido diretamente em $200 \mu \mathrm{L}$ de tampão de amostra para eletroforese, sendo aplicados $18 \mu \mathrm{L}$ ao gel. Do sobrenadante obtido foram aplicadas $10 \mu \mathrm{g}$ de proteínas totais ao gel de eletroforese.

\subsubsection{Clarificação do Homogenato}

Três testes para clarificação do homogenato bruto foram realizados: centrifugação, microfiltração em fibra-oca de poro 0,1 $\mu \mathrm{m}$ e ultrafiltração em fibra-oca de $750 \mathrm{kDa}$. A amostra obtida da lise celular (homogenato) foi divida em 3 partes iguais para a realização destes testes.

$>1^{\circ}$ Centrifugação (método tradicional):

$\mathrm{O}$ homogenato bruto foi centrifugado durante $2 \mathrm{~h}$ a uma velocidade de $17.696 \mathrm{~g} \mathrm{a} 4^{\circ} \mathrm{C}$. Após a centrifugação o sobrenadante foi separado do precipitado e filtrado à vácuo em membrana de poro $0,45 \mu \mathrm{m}$ para a retirada de precipitados que 
pudessem obstruir a passagem da amostra na coluna cromatográfica. Esta fração foi denominada clarificado centrifugado.

$>2^{\circ}$ Microfiltração em fibra-oca de poliestersulfona (GE Modelo: CFP$1-E-5 A)$ de poro $0,1 \mu \mathrm{m}$ e $1200 \mathrm{~cm}^{2}$ de área filtrante:

O homogenato bruto foi microfiltrado até que a amostra retida ficasse 3 vezes concentrada. Esse concentrado foi lavado com 6 vezes o seu volume com tampão acetato $25 \mathrm{mM}$ pH 6,0. A pressão transmembrana foi controlada em aproximadamente 5 psi durante o processo. Esta fração foi denominada clarificado microfiltrado.

$3^{\circ}$ Ultrafiltração em fibra-oca de poliestersulfona (GE Modelo: UFP750-E-4X2MA) de poro $750 \mathrm{kDa}$ e $850 \mathrm{~cm}^{2}$ de área de filtrante:

O homogenato bruto foi concentrado e diafiltrado da mesma maneira que 0 descrito para a fibra-oca de $0,1 \mu \mathrm{m}$. Esta fração foi denominada clarificado ultrafiltrado.

\subsubsection{Teste de precipitação do rfPspA3 em diferentes pH}

\subsubsection{Precipitação do homogenato}

O teste foi feito no intervalo de $\mathrm{pH}$ de 3,0 até 8,0, variando 0,5 ponto de $\mathrm{pH}$. $\mathrm{O}$ homogenato bruto estava com $\mathrm{pH}$ inicial de 7,3. Para aumentar o valor do $\mathrm{pH}$ utilizou-se solução de $\mathrm{NaOH} 5 \mathrm{M}$ e para abaixar, ácido acético glacial PA. Foram obtidas 11 amostras com os seguintes pH:3,0;3,5;4,0;4,5;5,0;5,5;6,0;6,5; 7,0; 7,5 e 8,0. Para $\mathrm{pH} \leq 6,0$ utilizou-se tampão acetato $25 \mathrm{mM}$ e acima desse valor, tampão Tris $25 \mathrm{mM}$. Após o ajuste de pH, as amostras ficaram $30 \mathrm{~min}$ em repouso, as que apresentaram turbidez devido a precipitação foram centrifugadas à $20.817 \mathrm{~g}$ por 90 min. O precipitado foi ressuspenso em uma solução de tampão Tris 25 mM $\mathrm{pH} 8,0$ com uréia $6 \mathrm{M}$. Foram medidas as proteínas totais e, tanto do precipitado como do sobrenadante, foram aplicadas $10 \mu \mathrm{g}$ em SDS-PAGE para análise.

\subsubsection{Precipitação isoelétrica da fração de eluição da segunda cromatografia}

Foi realizado outro teste em diferentes $\mathrm{pH}$ : precipitação por ponto isoelétrico do rfPspA3. Foi utilizada amostra após purificação em duas etapas de cromatografia, 
com aproximadamente $80 \%$ de pureza desta proteína, no intervalo de $\mathrm{pH}$ de 3,0 à 4,5 variando em 0,5 e o teste foi realizado tal qual o descrito no item anterior 3.4.5.1. As mesmas análises foram realizadas, porém com $5 \mu \mathrm{g}$ de proteínas totais aplicadas ao gel de eletroforese SDS-PAGE.

\subsubsection{Cromatografia: resinas, colunas e etapas das cromatografias estudadas}

As seguintes resinas foram utilizadas:

- IMAC-Sepharose (Immobilized Metal Affinity Chromatography): resina de afinidade por metais.

- Phenyl-Sepharose High-Sub Fast Flow: resina de interação hidrofóbica com o grupamento apolar fenil ligado a matriz.

- Q-Sepharose Fast Flow: resina de troca iônica com carga positiva;

- Sephacryl S-200 HR: resina de exclusão molecular (gel filtração) com poder de resolução para proteínas com massa molar entre 5.000 e 250.000 kDa.

- SP-Sepharose Fast Flow: resina de troca iônica com carga negativa.

As seguintes colunas foram utilizadas:

- XK16: 1,6 cm de diâmetro com 10 e $20 \mathrm{~mL}$ de resina e 5,5 e $11 \mathrm{~cm}$ de altura, respectivamente, para o estudo das condições de lavagem, eluição e limpeza.

- XK 26: 2,6 cm de diâmetro com $75 \mathrm{~mL}$ de resina e $15 \mathrm{~cm}$ de altura, para estudo da última etapa cromatográfica (SP-Sepharose).

- XK50: $5 \mathrm{~cm}$ de diâmetro com $500 \mathrm{~mL}$ de resina e $25 \mathrm{~cm}$ de altura, para estudo da sequência cromatográfica.

Todas as resinas e colunas foram obtidas da GE HealthCare/Amersham Pharmacia Biotech. As características de cada resina, como máxima pressão, fluxo, entre outros estão nos Anexos $A$ até $E$.

Com exceção da cromatografia em filtração em gel, as purificações cromatográficas em coluna empacotada foram realizadas seguindo as etapas descritas abaixo:

1. Equilíbrio: o equilíbrio da coluna foi feito nas condições de $\mathrm{pH}$ e condutividade que proporcionassem a máxima adsorção da proteína de interesse e mínima adsorção de impurezas na resina. $\mathrm{O} \mathrm{pH}$ e 
condutividade da amostra foram ajustados nos valores do tampão de equilíbrio.

2. Lavagem: nesta etapa utilizou-se a concentração mínima de eluente para retirar impurezas adsorvidas pela resina sem eluir a proteína de interesse.

3. Eluição: foi escolhido um tampão que permitisse a recuperação total da proteína de interesse adsorvida, mas que permitisse que impurezas que tenham maior afinidade pela resina permanecessem adsorvidas.

4. Limpeza: nesta etapa utilizou-se uma concentração de saturação do eluente para a retirada de todas as impurezas que tivessem uma alta afinidade pela resina.

5. Regeneração: esta última etapa pode ser feita separadamente ou junto com a limpeza. No caso da IMAC carregada com $\mathrm{Ni}^{+2}$, utilizou-se EDTA para a retirada do $\mathrm{Ni}^{+2}$ após o processo. No caso da resina Q-Sepharose foi utilizado $\mathrm{NaOH} \mathrm{0,1} \mathrm{M.}$

\subsubsection{Testes prévios de adsorção em tubos com as resinas}

\subsubsection{Amostras}

Phenyl-Sepharose: esta resina foi testada como uma opção de terceira etapa cromatográfica. Assim, as amostras utilizadas foram provenientes da eluição da segunda etapa cromatográfica. As amostras foram adicionadas nas resinas, após ajuste da condutividade de acordo com o tampão utilizado para equilíbrio, em uma proporção de 1,0 $\mathrm{mL}$ de resina para $5,0 \mathrm{~mL}$ de amostra.

Q-Sepharose: as amostras do sobrenadante do teste de precipitação do homogenato em diferentes $\mathrm{pH}$ (item 3.4.5.1) foram utilizadas para adsorção em resina de troca aniônica em tubos. As amostras foram centrifugadas 2 horas a 20.817 g e adicionadas nas resinas, após ajuste da condutividade de acordo com o tampão utilizado para equilíbrio, em uma proporção de $1,0 \mathrm{~mL}$ de resina para $5,0 \mathrm{~mL}$ de amostra.

SP-Sepharose: esta resina também foi estudada como uma opção de terceira etapa cromatográfica, assim, as amostras utilizadas foram provenientes da eluição da segunda etapa cromatográfica. Foram utilizadas as amostras do teste de 
precipitação isoelétrica em diferentes $\mathrm{pH}$ (item 3.4.5.2), até $\mathrm{pH}$ 6,5. Devido à alta concentração salina, as amostras foram dialisadas e, posteriormente, adicionadas às resinas, após ajuste de condutividade de acordo com o tampão utilizado para equilíbrio, em uma proporção de 1,0 mL de resina para 5,0 mL de amostra.

\subsubsection{Condições cromatográficas}

Phenyl-Sepharose: a resina foi previamente equilibrada com tampão Tris $25 \mathrm{mM} \mathrm{pH}$ de 7,5 à $8,0^{38}$, nas concentrações de 0,$75 ; 1,0 ; 1,25$ e $1,5 \mathrm{M}$ de $\left(\mathrm{NH}_{4}\right)_{2} \mathrm{SO}_{4}$ e também 1,0; 2,0 e 3,0 M de NaCl. Após 30 min de contato da amostra com a resina sob agitação, os tubos foram centrifugados e os sobrenadantes, correspondentes à fração não-adsorvida, foi submetido à eletroforese.

Q-Sepharose: a resina foi previamente equilibrada com tampão acetato $25 \mathrm{mM}+10 \mathrm{mM}$ de $\mathrm{NaCl}$ nos $\mathrm{pH}: 4,5 ; 5,0 ; 5,5$ e 6,0, ou com tampão Tris $25 \mathrm{mM}$ + $10 \mathrm{mM}$ de $\mathrm{NaCl}$ nos pH: 6,5; 7,0; 7,5 e 8,0. Após 30 min de contato da amostra com a resina, sob agitação, os tubos foram centrifugados e os sobrenadantes, correspondentes à fração não-adsorvida, foi submetido à eletroforese.

Uma vez definido o pH no qual toda rfPspA3 foi adsorvida, foi testada a influência da condutividade sobre a adsorção seletiva da proteína. Os testes foram feitos da mesma forma que o descrito acima, mas a resina foi equilibrada com tampão adequado contendo uma concentração de $\mathrm{NaCl}$ que variou de 0 a $500 \mathrm{mM}$.

$\mathrm{O}$ homogenato teve seu $\mathrm{pH}$ ajustado, e $\mathrm{NaCl}$ foi adicionado para obterem-se concentrações variando de 0-500 mM, adicionando posteriormente as amostras à resina equilibrada com o respectivo tampão. Após 30 min de contato sob agitação, os tubos foram centrifugados e o sobrenadante foi dialisado e aplicado à eletroforese.

SP-Seharose: o teste realizado para esta resina foi semelhante ao feito para a resina Q-Sepharose nos valores de $\mathrm{pH}$ de 5,0 à 6,5 com tampão Histidina 20 $\mathrm{mM}$. Após a definição do pH de adsorção, foram testadas as concentrações de $\mathrm{NaCl}$ de 0,0 a $100 \mathrm{mM}$. 


\subsubsection{Cromatografia em coluna empacotada}

As etapas de cromatografia em coluna foram operadas pelo Äkta Explorer (Amersham Pharmacia Biotech) (Figura 3.3) em volumes de colunas pré-definidos de acordo com a concentração de proteínas totais das amostras a serem separadas. Utilizou-se fluxo linear de $150 \mathrm{~cm} / \mathrm{h}$, o qual variou em $\mathrm{mL} / \mathrm{min}$ de acordo com a área da coluna utilizada. A Equação 3.2 mostra o cálculo de transformação do fluxo linear para volumétrico.

$$
F V=\frac{F L * \pi * R^{2}}{60} \quad \text { Equação } 3.2
$$

Em que: $F V=$ fluxo volumétrico $(\mathrm{mL} / \mathrm{min}) ; \mathrm{FL}=$ fluxo linear $(\mathrm{cm} / \mathrm{h})$ e $\mathrm{R}=$ raio da coluna $(\mathrm{cm})$.

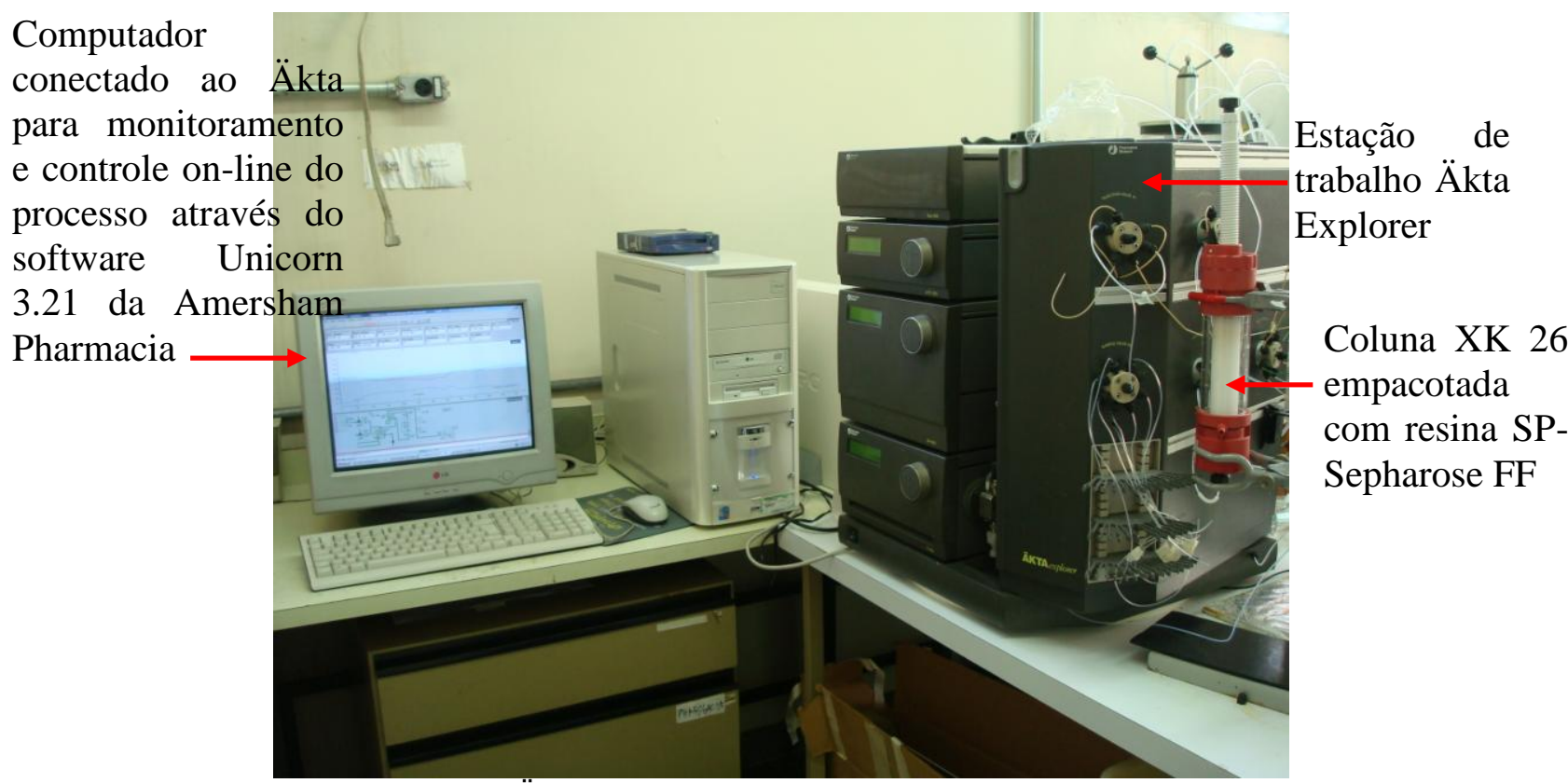

Figura 3.3: Estação de trabalho Äkta Explorer da Amersham Phamacia Biotech munido de 2 bombas. $\mathrm{Na}$ figura há o computador que monitora e controla o sistema através do software Unicorn 3.21 e a coluna XK 26 empacotada com $75 \mathrm{~mL}$ da resina SP-Sepharose Fast-Flow.

\subsubsection{Estabelecimento das condições de dessorção em coluna empacotada}

Para definir as condições de lavagem e eluição foi utizada a coluna XK16 com $10 \mathrm{~mL}$ de volume de coluna para a resina Q-Sepharose, $20 \mathrm{~mL}$ para IMACSepharose e $15 \mathrm{~mL}$ para SP-Sepharose. Foram determinadas as melhores condições para retirada de impurezas nas frações de lavagem e limpeza e máxima recuperação da proteína de interesse na fração de eluição. As amostras utilizadas 
foram as mesmas citadas no item 3.4.7.1 e a adsorção foi realizada nas condições definidas pelos testes em tubos detalhados no item 3.4.7.2, para cada resina, respectivamente.

A resina IMAC-Sepharose foi carregada com $\mathrm{NiSO}_{4}$ antes de ser utilizada. $\mathrm{O}$ eluente utilizado para esta resina foi o imidazol e o pH utilizado foi 8,0. Para a condição de lavagem foram testadas as concentrações de 7, 10, 15 e $20 \mathrm{mM}$ do eluente e 150, 200 e 250 mM para a eluição. Foram adicionados $300 \mathrm{mM}$ de $\mathrm{NaCl}$ aos tampões para evitar ligações inespecíficas ao metal ligado na resina.

Para a Phenyl-Sepharose foram utilizados como eluentes $\left(\mathrm{NH}_{4}\right)_{2} \mathrm{SO}_{4}$ e $\mathrm{NaCl}$, com as seguintes concentrações para eluição descontínua : 1,0; 0,8; 0,6; 0,4; 0,1 e $0,0 \mathrm{M}$ de $\left(\mathrm{NH}_{4}\right)_{2} \mathrm{SO}_{4}$ e 1,$0 ; 0,75 ; 0,50 ; 0,25 ; 0,0 \mathrm{M}$ de NaCl . Posteriormente, foi realizado outro teste para ajustar os valores de adsorção e dessorção na tentativa de evitar perda na fração não-adsorvida e separar algumas impuras que estavam sendo eluídas juntas com o rfPspA3. Neste terceiro teste foi utilizado $\mathrm{NaCl}$ e a adsorção foi feita com 2,5 $\mathrm{M}$ e testes de dessorção foram realizados nas concentrações de 1,5; 1,0; 0,5 e 0,0 M. As frações de limpeza foram obtidas com tampão Tris $25 \mathrm{mM} \mathrm{pH} \mathrm{8,0.}$

Para a Q-Sepharose, resina de troca-aniônica, utilizou-se $\mathrm{NaCl}$ como eluente. Os valores de $\mathrm{pH}$ e condutividade ideais para adsorção foram previamente determinados nos testes em tubos descritos no item 3.4.7.2. O estudo das condições para lavagem foi realizado com as concentrações de 75, 100 e $125 \mathrm{mM}$ do eluente e para eluição do rfPspA3, concentrações de 250, 275 e $300 \mathrm{mM}$ de $\mathrm{NaCl}$.

Para a cromatografia em SP-Sepharose foi investigada a eluição por aumento de condutividade (com adição de $\mathrm{NaCl}$ ) e por mudança de $\mathrm{pH}$. A adsorção foi previamente definida (item 3.4.7.2) e em seguida foram testadas as concentrações de 70, 100 e $150 \mathrm{mM}$ de $\mathrm{NaCl}$ em pH 6,0 e os seguintes pH para eluição: 7,0; 7,5 e 8,0 com $10 \mathrm{mM}$ de $\mathrm{NaCl}$. Posteriormente, foram realizados testes de dessorção em pH 7,0 com concentrações de 40,60, 80 e $100 \mathrm{mM}$ de $\mathrm{NaCl}$, e os resultados foram comparados aos obtidos pela eluição com diferentes concentrações de Tampão fosfato pH 7,0 (20, 30, 40 e 50 mM). 


\subsubsection{Estabelecimento da sequência das etapas cromatográficas}

Após a definição das condições de cada cromatografia visando aumentar a eficiência do processo, maximizando o rendimento e pureza em cada etapa cromatográfica, tal como descrito nos item anterior (3.4.8.1), a melhor sequência cromatográfica foi avaliada para purificar um volume maior de amostra.

As resinas Q-Sepharose e IMAC-Sepharose foram pré-determinadas como etapas cromatográficas, assim experimentos foram realizados com elas nas duas seqüências possíveis utilizando $250 \mathrm{~mL}$ e $500 \mathrm{~mL}$ de volume de coluna, respectivamente, em coluna XK50.

Com a necessidade de uma terceira etapa, as outras três resinas já citadas (Phenyl-Sepharose, Sephacryl S-200 e SP-Sepharose) foram estudadas para desenvolver o melhor processo de purificação.

O teste com a resina Sephacryl S-200 High Resolution (HR) foi realizado em coluna pré-empacotada com $320 \mathrm{~mL}$ de volume de coluna. O tampão utilizado foi fosfato de sódio $50 \mathrm{mM}$ com $150 \mathrm{mM}$ de $\mathrm{NaCl}$. O fluxo foi de $1,3 \mathrm{~mL} / \mathrm{min}$ e introduzido no máximo $5 \%$ do volume de amostra em relação ao volume de coluna (Anexo A). A amostra foi primeiramente concentrada e diafiltrada contra o tampão de corrida em membrana Pellicon XL Biomax 5 da Millipore de $5 \mathrm{Kda}$ de poro em Lab Scale TFF System da Millipore, com pressão transmembrana de 20 psi (30 psi na entrada e 10 psi na saída), resultando em uma solução com concentração protéica de $6,1 \mathrm{mg} / \mathrm{mL}$, que foi aplicada à cromatografia.

A cromatografia em SP-Sepharose foi realizada nesta etapa com $75 \mathrm{~mL}$ de volume de coluna nas condições determinadas nos testes de adsorção em tubos (item 3.4.7.2) e dessorção (item 3.4.8.1). 


\subsection{MÉTODOS ANALÍTICOS}

\subsubsection{Cálculo dos parâmetros de cultivo}

A máxima velocidade específica de crescimento $\left(\mu_{\text {máx }}\right)$ e fator de conversão de substrato a células $\left(Y_{X / S}\right)$ foram calculados graficamente através dos dados obtidos no cultivo descontínuo pelo software Microsoft Excel. Para $\mu_{\text {máx }}$ foi feita uma linearização dos pontos da fase exponencial de crescimento celular, sendo o coeficiente angular desta linearização o valor da velocidade específica e, para o $Y_{x / S}$, foi montada uma curva de concentração de células versus concentração de substrato, sendo o coeficiente angular desta curva o valor deste fator. Estes parâmetros foram usados para desenhar a estratégia de alimentação do biorreator.

Foi calculada também a produtividade celular através da Equação 3.3.

$$
P=\frac{P V}{T} \quad \text { Equação } 3.3
$$

Em que: $P$ = produtividade em g/L.h; $P V=$ produção celular volumétrica em g/L e $T$ = tempo total do processo de produção em $\mathrm{h}$.

\subsubsection{Determinação da relação massa seca $\times \mathrm{DO}_{600 \mathrm{~nm}}$ de suspensões celulares}

A leitura de suspensões celulares foi realizada em espectrofotômetro Hitachi U-1800. A leitura foi feita na faixa de 0,100 a 0,500 no comprimento de onda $600 \mathrm{~nm}$. A amostra foi diluída em $\mathrm{NaCl}$ 0,85\% sempre que necessário para que a leitura caísse nessa faixa e a solução de $0,85 \%$ de $\mathrm{NaCl}$ foi empregada como branco.

Para determinação da massa celular seca, durante os cultivos em reator foi coletado um volume suficiente de células quando a $\mathrm{DO}_{600 \mathrm{~nm}}$ estava em torno de 40 . A partir desta suspensão foram preparadas diferentes diluições. Os valores de $\mathrm{DO}_{600 \mathrm{~nm}}$ das suspensões obtidas foram lidos, $10 \mathrm{~mL}$ foram centrifugados a $17800 \mathrm{~g}$ por 60 minutos e o sobrenadante descartado. As células presentes no pellet foram secas em tubos previamente pesados, a $60{ }^{\circ} \mathrm{C}$ até que se obtivesse massa constante. A concentração em $\mathrm{g} / \mathrm{L}$ da suspensão colocada em cada tubo foi determinada pela Equação 3.3. Foi construído um gráfico de $\mathrm{DO}_{600 \mathrm{~nm}}$ versus 
concentração celular em g/L, cujo coeficiente angular foi usado para converter a leitura de $\mathrm{DO}_{600 \mathrm{~nm}}$ em massa seca $(\mathrm{g} / \mathrm{L})$.

$$
M S=\frac{M t c-M t v}{V}
$$

Em que: MS é a massa celular seca em g/L; Mtc é a massa do tubo contendo o pellet bacteriano em g; Mtv é a massa do tubo vazio em g; V é o volume em L.

\subsubsection{Determinação da concentração de glicose, glicerol e ácido acético}

As concentrações de glicose, glicerol e ácido acético nas amostras dos cultivos foram determinadas por HPLC (Shimadzu). Foi utilizada para essas análises a coluna Aminex HPX-87H (Biorad), fase móvel $\mathrm{H}_{2} \mathrm{SO}_{4} 5 \mathrm{mM}$, temperatura de $60{ }^{\circ} \mathrm{C}$ e vazão de $0,6 \mathrm{~mL} / \mathrm{min}$ em 30 minutos de corrida para cada amostra. Os detectores utilizados foram Índice de Refração (RID) para glicose e glicerol e ultravioleta em $210 \mathrm{~nm}$ para ácido acético.

\subsubsection{Determinação da estabilidade do plasmídeo}

A estabilidade foi determinada em diferentes tempos do cultivo. A amostra da suspensão celular retirada do reator foi diluída adequadamente em salina $(\mathrm{NaCl}$ 0,85\%) e $100 \mu \mathrm{L}$ foi semeado para uma placa LB/ágar sem antibiótico. Após 24h, repicaram-se 70 colônias, ou o número de colônias que cresceram, para uma placa com $25 \mathrm{mg} / \mathrm{L}$ de kanamicina e para outra placa sem kanamicina (controle), as placas foram incubadas a $37{ }^{\circ} \mathrm{C}$ por 24 horas. Calculou-se então, em porcentagem, a quantidade de colônias que cresceram na placa com o antibiótico em relação às colônias que cresceram na placa sem antibiótico.

\subsubsection{Quantificação de proteínas}

Foi feita pelo método segundo Lowry et al..$^{39}$, utilizando o reagente FolinCiocalteau e albumina bovina como padrão. A leitura das amostras foi realizada em $750 \mathrm{~nm}$ de comprimento de onda pelo espectrofotômetro Hitachi U-1800. Dentre os diversos interferentes deste método, os principais encontrados nas amostras deste trabalho foram o imidazol, a uréia e o Tris (este último em altas concentrações). 
Assim, as amostras contendo um destes interferentes foram previamente dialisadas contra um tampão no mesmo $\mathrm{pH}$ da amostra em membranas de diálise com poro de $12 \mathrm{kDa}$ por pelo menos 24 horas.

\subsubsection{Eletroforese SDS-PAGE}

O método utilizado foi segundo Laemmli et al. ${ }^{40}$, empregando-se gel de separação a $12 \%$ de acrilamida e $5 \%$ para o gel de empilhamento. O aparelho MiniProtean 3 Cell da Biorad foi utilizado. As amostras com alta concentração de $\mathrm{NaCl}$ ou outros interferentes foram previamente dialisadas por $24 \mathrm{~h}$ em membranas de diálise com poro de $12 \mathrm{kDa}$.

As amostras foram preparadas para um volume total de $18 \mu \mathrm{L}$. As amostras provenientes de suspensões celulares foram ajustadas para $\mathrm{DO}_{600 \mathrm{~nm}}$ igual a 5,0 e fervidas por 15 minutos para garantir a lise total das células. As amostras da purificação foram preparadas de forma a aplicar-se 5 a $15 \mu \mathrm{g}$ de proteínas totais ao gel. As amostras, cujo volume a ser aplicado ao gel foi superior a 13,5 $\mu \mathrm{L}$, foram concentradas a vácuo em concentrador Centrivap da Labconco nas temperaturas de $35{ }^{\circ} \mathrm{C}$ para volumes abaixo ou $45{ }^{\circ} \mathrm{C}$ para volumes acima de $100 \mu \mathrm{L}$. Após concentração, as amostras foram ressuspensas com o tampão de amostra 4 vezes concentrado para $18 \mu \mathrm{L}$. Antes de serem adicionadas ao gel de eletroforese, as amostras foram fervidas a $100{ }^{\circ} \mathrm{C}$ em Heat Block dry bath incubator da Fisher Scientific por 2 minutos. O tempo de corrida da eletroforese foi de cerca de $1 \mathrm{~h}$, ou até que o corante das amostras saísse totalmente do gel. A corrida foi realizada nas condições iniciais de 200 V, 400 mA e 100 W e, após a corrida o gel foi corado com Comassie Blue R-250 por pelo menos 2 h sob agitação de 60 rpm e depois descorado com descorante $30 \%$ etanol e $10 \%$ ácido acético.

\subsubsection{Determinação de Pureza Relativa do rfPspA3}

Para esta análise foram utilizados dois métodos: densitometria e HPSEC (high performance size exclusion chromatography).

Densitometria: Para a densitometria das bandas de proteína nos géis de eletroforese foi utilizado o densitômetro Biorad modelo GS-800. O software Quantity 
one 4.6.3 foi empregado para determinação da pureza relativa da banda de rfPspA3 em relação ao total de bandas de proteínas presentes em cada caneleta dos géis.

HPSEC: Amostras contendo proteínas foram analisadas por HPLC (Shimadzu) para determinação da porcentagem relativa da área do pico de rfPspA3 em relação à área total dos picos do cromatograma. Para a análise foi utilizada a coluna de gel filtração TSKgel G2000SWXL da Tosoh Bioscience, fase móvel tampão fosfato $50 \mathrm{mM}+\mathrm{NaCl} 200 \mathrm{mM}$, temperatura de $25^{\circ} \mathrm{C}$ e vazão de $0,6 \mathrm{~mL} / \mathrm{min}$ em 40 minutos de corrida para cada amostra. A leitura foi feita por UV à $280 \mathrm{~nm}$.

\subsubsection{Western Blotting}

Foi realizado o método segundo Miyaji et al. ${ }^{41}$, a qual cedeu os anticorpos anti-PspA produzidos em camundongos. Após a eletroforese SDS-PAGE (item 3.5.6), as proteínas do gel foram transferidas para uma membrana de nitrocelulose (Hybond-ECL, Amersham Biosciences) a $100 \mathrm{~V}$ e $350 \mathrm{~mA}$ por 1 hora, empregando o seguinte tampão de transferência: $25 \mathrm{mM}$ Tris $+192 \mathrm{mM}$ glicina $+20 \%$ etanol + $0,1 \%$ dodecil sulfato de sódio. Os sítios da membrana foram bloqueados com leite desnatado $5 \%$. Como anticorpo secundário foi empregado anti-soro de camundongo produzido em coelho conjugado à peroxidase e a revelação foi feita com diaminobenzidina (DAB), $\mathrm{CoCl}_{2}$ e $\mathrm{H}_{2} \mathrm{O}_{2}$.

\subsubsection{Dicroísmo Circular}

Foi realizado segundo Kelly et al. ${ }^{42}$. Foi utilizado $60 \mu \mathrm{L}$ de amostra com $\sim 8,5$ $\mu \mathrm{M}$ de concentração para análise. Esta foi realizada pelo espectro polarímetro Jasco modelo J-810 em temperatura ambiente utilizando o Software Spectra Manager numa faixa de 185-260 $\mathrm{nm}$ de comprimento de onda. 


\section{Resultados e Discussão}

\subsection{EXPRESSÃo do GENE E CINÉTICA DE CRESCIMENTO DE E. coli BL21(DE3) PARA PRODUÇÃO DE rfPspA3}

\subsubsection{Testes de expressão do gene fPspA3 em E. coli BL21(DE3) e seleção do clone produtor}

A clonagem foi obtida pela Dra. Eliane Miyaji com o gene fpspA3 em vetor $\mathrm{pET} 37 \mathrm{~b}+\mathrm{o}$ qual foi usado para transformar E. coli BL21(DE3). Inicialmente, foi feito um teste de expressão em meio LB com essa bactéria transformada. O cultivo foi feito em frascos agitados (frascos de $300 \mathrm{~mL}$ com $30 \mathrm{~mL}$ de meio) semeando 4 colônias diferentes em frascos separados para selecionar a que produzisse a maior quantidade a rfPspA3. A Figura 4.1 apresenta o resultado do teste de expressão das 4 colônias nos cultivos com e sem indução (controle).

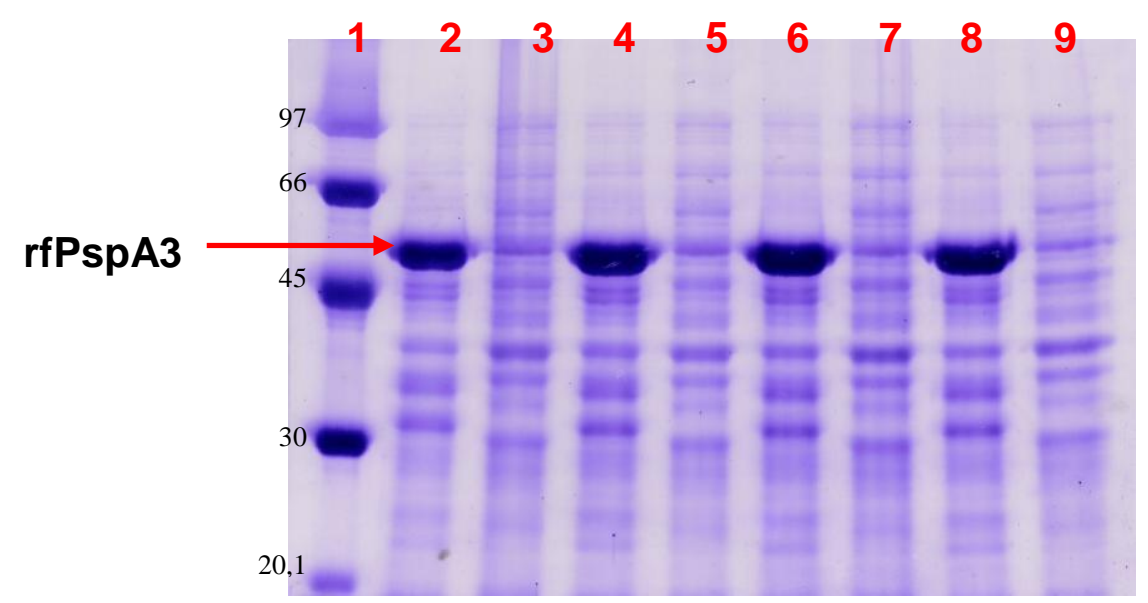

Figura 4.1: Gel de eletroforese do teste de expressão de 4 diferentes colônias da $E$. coli BL21(DE3) transformadas com $\mathrm{pET} 37 \mathrm{~b}^{+} / \mathrm{rfpspA3}$. 1-Padrão de massa molecular (kDa), 2-Colônia 1 após $4 \mathrm{~h}$ de indução, 3-Colônia 1 controle (sem indução), 4- Colônia 2 após $4 \mathrm{~h}$ de indução, 5- Colônia 2 controle, 6- Colônia 3 após 4 h de indução, 7- Colônia 3 controle, 8Colônia 4 após $4 \mathrm{~h}$ de indução, 9 - Colônia 4 controle.

De acordo com o gel, as 4 colônias apresentaram uma produção equivalente de rfPspA3 (indicado na Figura 4.1). Sabe-se que essa é a proteína de interesse, pois ela possui uma massa molecular aparente em torno de $50 \mathrm{kDa}$, além de não estar presente nas amostras dos cultivos não induzidos. Todas as colônias apresentaram uma boa expressão. A colônia 4 foi escolhida para o desenvolvimento posterior do trabalho por apresentar uma colônia bem isolada evitando a coleta de 
"células satélites" que possam estar presentes em volta da colônia. Observa-se também que não houve escape na produção da proteína nos cultivos sem indução (caneletas 3, 5, 7 e 9) demonstrando assim um bom sistema de controle da expressão do gene de interesse.

\subsubsection{Cultivo em frascos agitados}

Após isolar a colônia 4 e preparar um estoque congelado para 0 prosseguimento do trabalho, foi feito um estudo da cinética de crescimento, também em frascos agitados, para conhecer seu comportamento em meio complexo (LB) e meio definido MQD com glicose como fonte de carbono (Figura 4.2).

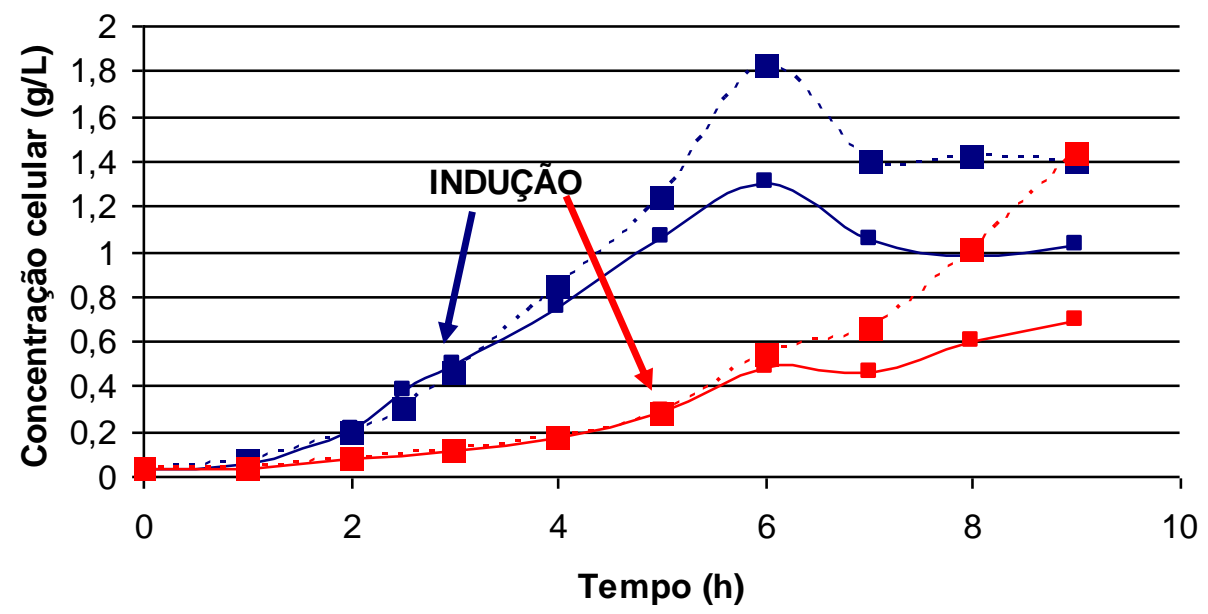

Figura 4.2: Curva de crescimento nos meios LB e MQD utilizando E. coli BL21(DE3) carregando pET37b+/rfpspA3 - (- - ) meio LB induzido, ( - - -) meio LB sem indução, (- - ) meio MQD induzido e (- - - ) meio MQD sem indução.

Nota-se na Figura 4.2 que, como era esperado, no meio rico LB o crescimento celular foi mais rápido que em meio definido. A indução no meio LB foi feita com $D_{600 n m ~}^{2,5}$ (concentração celular 0,45 g/L) após 3 horas de cultivo, enquanto que a indução no meio MQD foi feita com $\mathrm{DO}_{600 \mathrm{~nm}} \sim 1,0(0,3 \mathrm{~g} / \mathrm{L})$ após 5 horas de cultivo. Apesar de o microrganismo demorar um pouco mais para crescer em meio definido, após 9 horas de cultivo as concentrações celulares dos dois meios foram semelhantes nos cultivos controle $(\sim 1,4 \mathrm{~g} / \mathrm{L})$. Já nos cultivos que foram induzidos, a concentração celular obtida com o meio LB $(\sim 1,0 \mathrm{~g} / \mathrm{L})$ foi maior do que a obtida com o meio MQD $(0,7 \mathrm{~g} / \mathrm{L})$, concentrações menores que no cultivo controle, 
sem indução. Isto ocorre devido a uma mudança no metabolismo da $E$. coli: durante a fase de indução com IPTG, o metabolismo da bactéria é direcionado para a síntese protéica e não mais para a divisão celular diminuindo a velocidade de crescimento $^{43}$. Assim, como a concentração celular estava mais elevada no momento da indução no meio em LB, sua $D_{600 \mathrm{~nm}}$ final foi um pouco maior. Está apresentada na Figura 4.3 a eletroforese das amostras dos cultivos com os dois meios. Ambos permitiram a obtenção do rfPspA3.

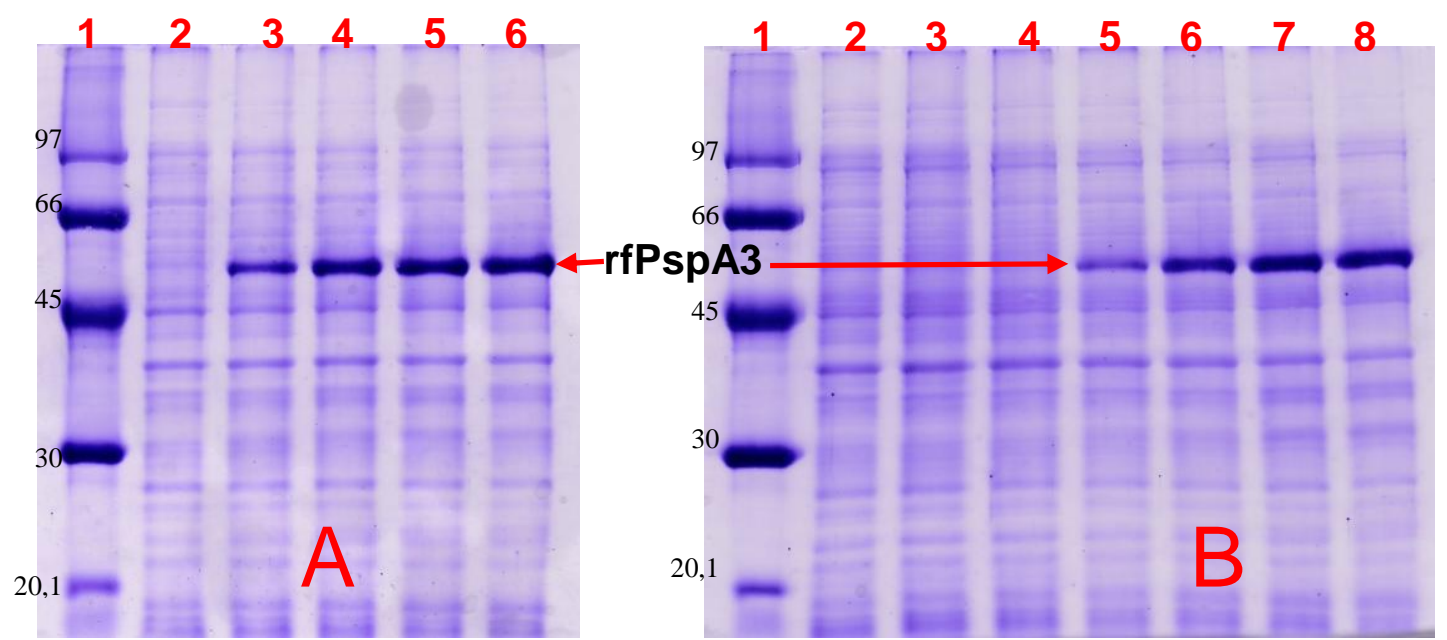

Figura 4.3: A - Eletroforese do rfPspA3 no meio LB. 1- Padrão de massa molecular (kDa), 2- antes da indução, 3- após 1 hora de indução, 4- após 2 horas de indução, 5- após 3 horas de indução, 6- após 4 horas de indução. B - Eletroforese do rfPspA3 no meio MQD. 1Padrão de massa molecular $(\mathrm{kDa}), 2-3 \mathrm{~h}$ de cultivo, 3-4 $\mathrm{h}$ de cultivo, 4-5 $\mathrm{h}$ de cultivo (antes da indução), 5- após 1 hora de indução, 6- após 2 horas de indução, 7- após 3 horas de indução, 8- após 4 horas de indução.

Comparando os resultados mostrados na Figura 4.3, nota-se que no meio LB a expressão do gene foi mais rápida, enquanto que em meio MQD o sistema de expressão encontrou-se mais reprimido. Mesmo assim, foi obtida uma quantidade equivalente de rfPspA3 nos dois meios e também não ocorreu escape antes da indução. Assim, definiu-se o meio $\mathrm{MQD}$ para se trabalhar com o cultivo em biorreator, pois segundo Zhang e Greasham, um meio quimicamente definido facilita o controle e monitoramento dos parâmetros durante a fase de alimentação nos cultivos em batelada alimentada ${ }^{44}$.

\subsubsection{Cultivo Descontínuo em biorreator de $5 \mathrm{~L}$}

Após a seleção do clone produtor e estabelecimento da cinética em frascos agitados, cultivos descontínuos foram feitos em biorreator de $5 \mathrm{~L}$ para obtenção dos 
parâmetros cinéticos necessários para realização dos cultivos descontínuos alimentados. Foram feitos 2 cultivos em meio MQD utilizando como fontes de carbono glicose ou glicerol. As Figuras 4.4 e 4.5 mostram os resultados dos parâmetros velocidade específica máxima de crescimento $\left(\mu_{\max }\right)$ e fator de conversão de substrato em células $\left(\mathrm{Y}_{\mathrm{X} / \mathrm{S}}\right)$.
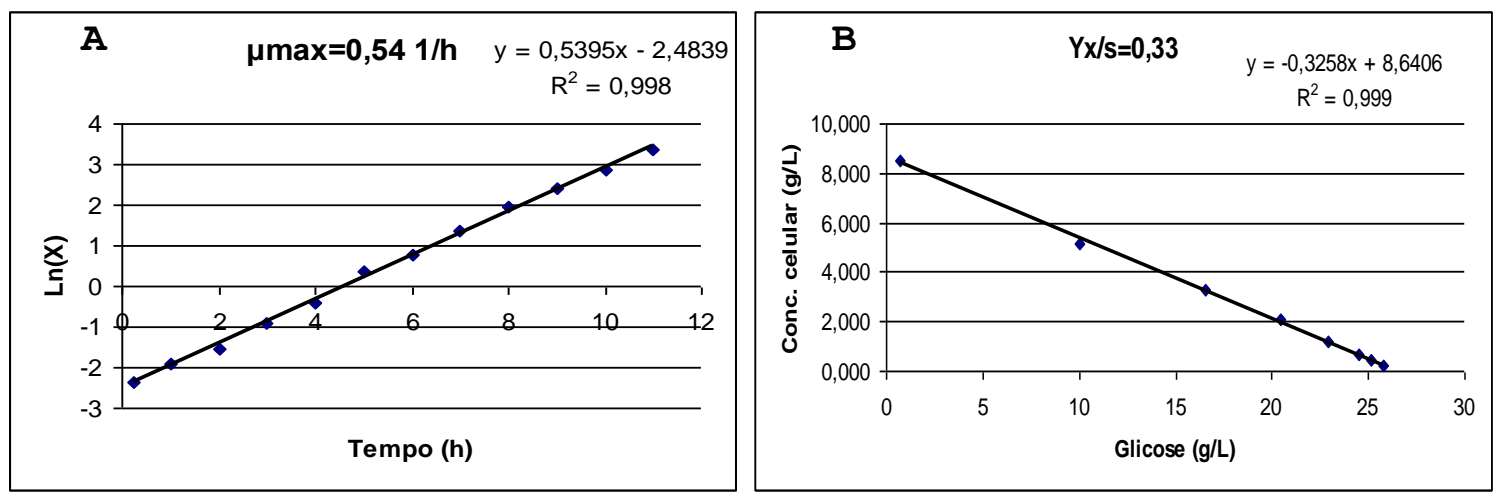

Figura 4.4: Parâmetros do cultivo descontínuo de E. coli BL21(DE3) em meio MQD utilizando glicose como fonte de carbono em biorreator de $5 \mathrm{~L}$ para produção de rfPspA3. A - Velocidade específica máxima de crescimento $\left(\mu_{\text {máx }}\right)$; B - Fator de conversão de substrato em células $\left(\mathrm{Y}_{\mathrm{X} / \mathrm{S}}\right)$.
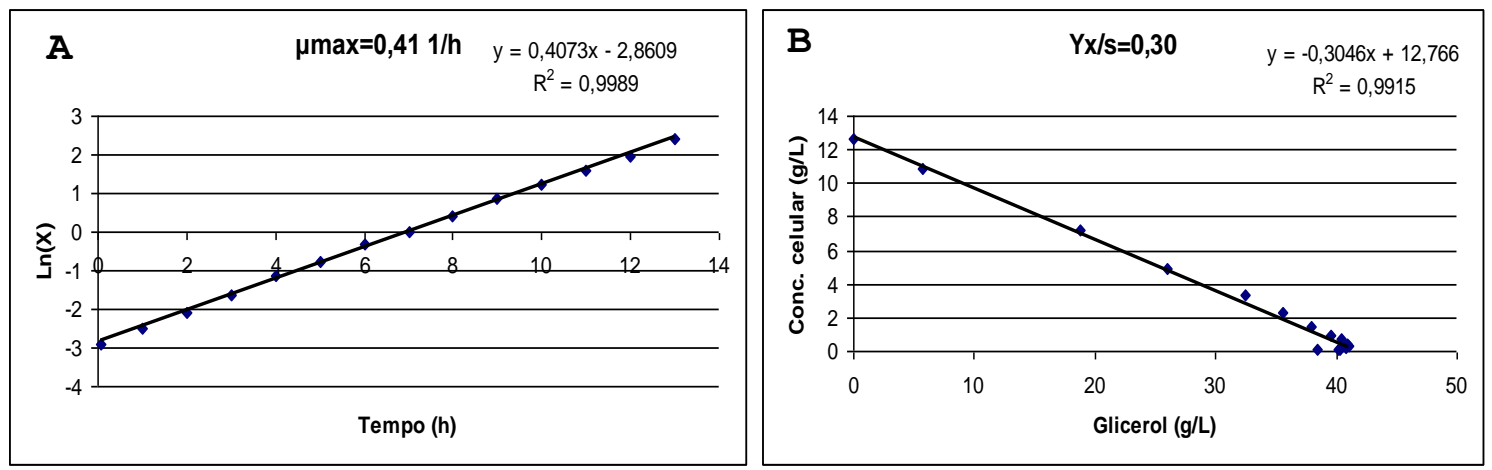

Figura 4.5: Parâmetros do cultivo descontínuo de E. coli BL21(DE3) em meio MQD utilizando glicerol como fonte de carbono em biorreator de $5 \mathrm{~L}$ para produção de rfPspA3. A - Velocidade específica máxima de crescimento $\left(\mu_{\text {máx }}\right)$; B - Fator de conversão de substrato em células $\left(\mathrm{Y}_{\mathrm{X} / \mathrm{S}}\right)$.

A partir dos dados apresentados nos gráficos (Figuras 4.4 A e $4.5 \mathrm{~A}$ ) calculou-se a velocidade específica máxima de crescimento no cultivo com glicose como $0,54 \mathrm{~h}^{-1}$, maior que no cultivo com glicerol $\left(0,40 \mathrm{~h}^{-1}\right)$. A conversão de substrato em células (Figuras $4.4 \mathrm{~B}$ e $4.5 \mathrm{~B}$ ) foi semelhante nos dois cultivos: $0,33 \mathrm{~g} / \mathrm{g}$ para o cultivo com glicose e $0,30 \mathrm{~g} / \mathrm{g}$ com glicerol. Apesar de o cultivo com glicerol ter apresentado menor velocidade de crescimento, nele obteve-se maior concentração 
celular no momento da indução (12,6 g/L contra 8,5 g/L no cultivo com glicose), como mostram as Figuras 4.6 e 4.7.

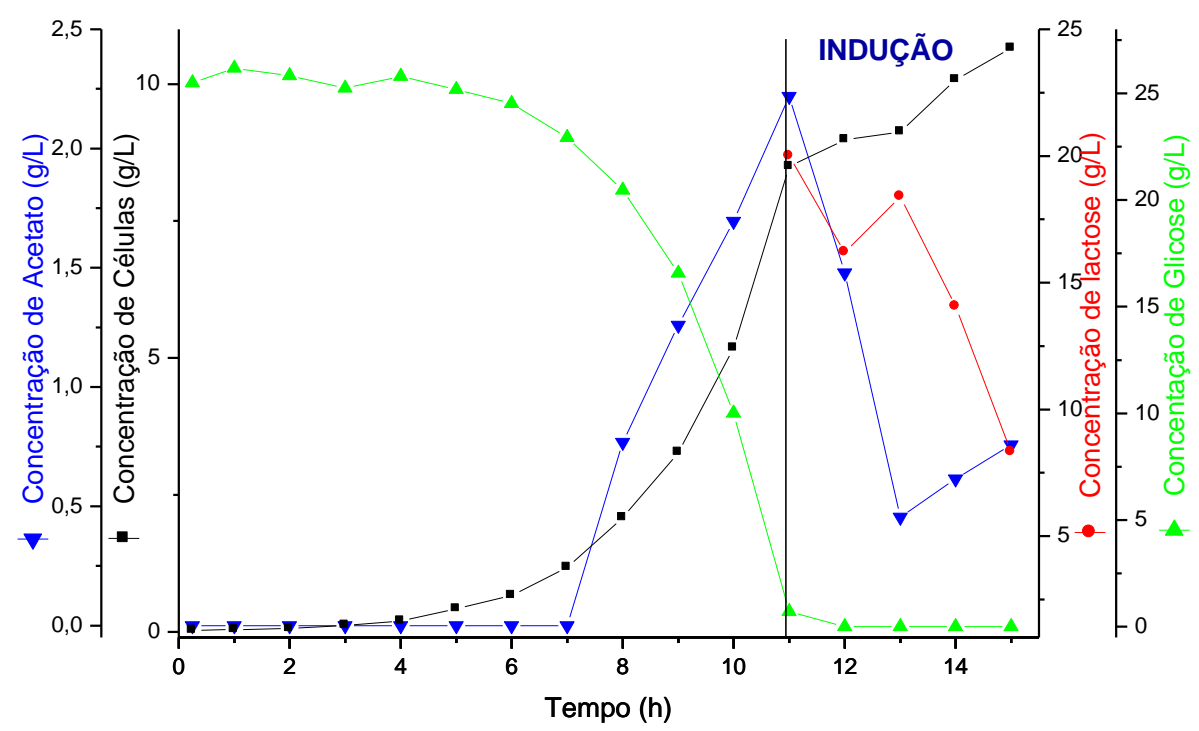

Figura 4.6: Cultivo Descontínuo de E. coli BL21(DE3)+pET37b $/ r f p s p A 3$ em meio MQD com glicose como fonte de carbono. Perfil do consumo de glicose $(-\rightarrow)$, do consumo de lactose $(-)$, do crescimento celular $(\neg)$, e produção de ácido acético $(\neg \nabla)$.

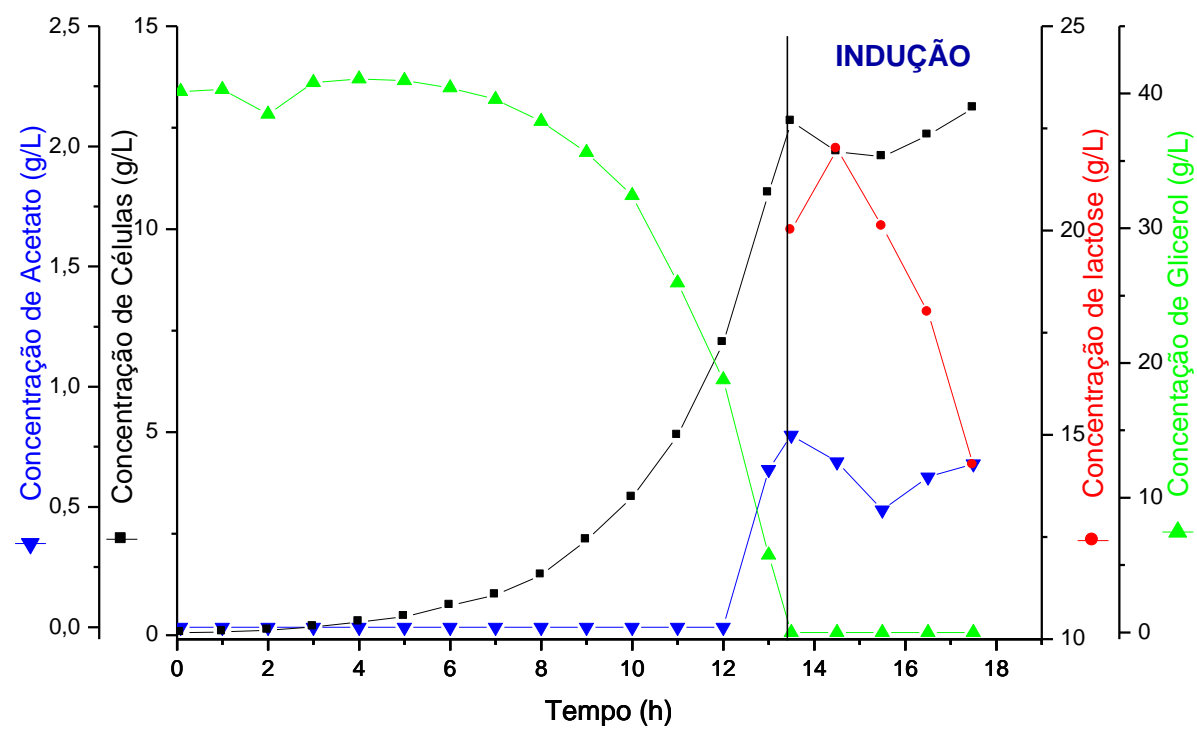

Figura 4.7: Cultivo Descontínuo de E. coli BL21(DE3)+pET37b $/ r f p s p A 3$ em meio MQD com glicerol como fonte de carbono. Perfil do consumo de glicerol ( - - $)$, do consumo de lactose $(-)$, do crescimento celular $(-)$, e produção de ácido acético $(\longrightarrow-$ ).

Podemos observar que após a indução o crescimento celular parou como era esperado, pois, com a presença dos indutores (IPTG e lactose) o metabolismo bacteriano voltou-se para a produção protéica da mesma forma que observado 
durante o cultivo em frascos agitados. A lactose, além de indutora, também foi utilizada pelo microrganismo como fonte de carbono durante a fase de indução, pois esta foi adicionada após o total consumo das fontes de carbono, identificado pelo aumento abrupto do $\mathrm{O}_{2}$ dissolvido no reator. Observa-se também que a lactose não foi consumida totalmente nos dois cultivos, indicando que seria possível aumentar o tempo de indução nestes cultivos.

Durante os cultivos houve produção de ácido acético na fase exponencial de crescimento celular. Este composto é tóxico quando presente em concentração igual ou maior que $3,0 \mathrm{~g} / \mathrm{L}^{21}$, porém, a quantidade produzida nestes cultivos foi baixa 0 suficiente para não inibir o crescimento celular. Nota-se ainda nas figuras 4.6 e 4.7 que a produção de acetato foi menor no cultivo com glicerol que com glicose, o que poderia ter ocasionado a maior produção celular neste cultivo (12,6 g/L no momento da indução). Segundo Martinéz et al. ${ }^{45}$, o uso de glicerol como fonte de carbono produziu cerca de $83,3 \%$ menos acetato que o uso de glicose nas duas diferentes cepas estudadas.

O valor da produtividade celular foi semelhante em ambos cultivos obtendose $0,74 \mathrm{~g} / \mathrm{L} . \mathrm{h}$ no cultivo com glicerol e 0,71 g/L.h no cultivo com glicose, pois a concentração celular foi maior antes da indução no cultivo com glicerol, porém o tempo gasto até esse momento também foi maior que no cultivo com glicose. Podese observar ainda que após o total consumo da fonte de carbono dos cultivos, a concentração de acetato começou a diminuir, pois ele passou a ser consumido pela E. coli como fonte de carbono. Apesar de a lactose ter sido adicionada no momento de esgotamento da glicose ou glicerol, este açúcar deve ser hidrolisado pela bactéria antes de ser consumido, o que faz com que ela utilize outra fonte de carbono disponível (acetato) até o consumo da lactose.

A figura 4.8 mostra a produção de rfPspA3 nos cultivos descontínuos realizados. 


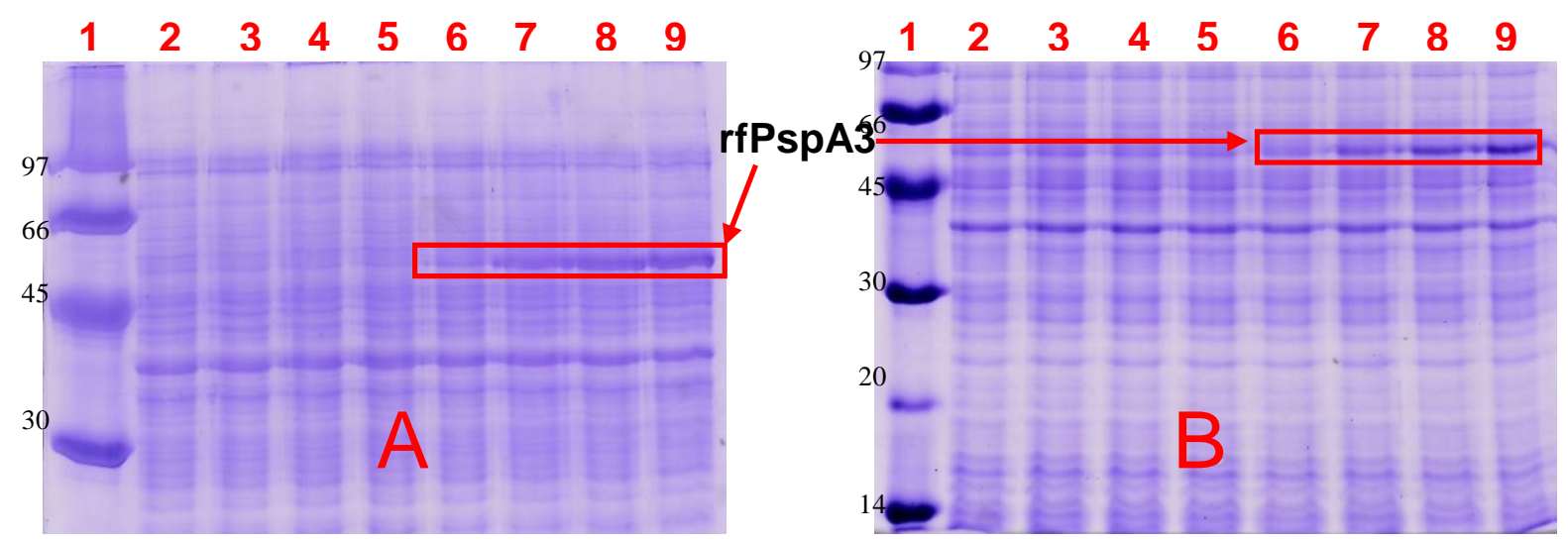

Figura 4.8: A - Gel de eletroforese da produção do rfPspA3 durante o cultivo descontínuo com glicose como fonte de carbono. 1-Padrão de massa molecular em kDa; $2-8^{\mathrm{a}}$ hora do

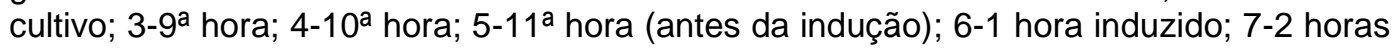
induzido; 8-3 horas induzido; 9-4 horas induzido. B - Gel de eletroforese da produção do rfPspA3 durante o cultivo descontínuo com glicerol como fonte de carbono. 1-Padrão de peso molecular em kDa; $2-11^{\underline{a}}$ hora do cultivo; $3-12^{a}$ hora; 4-13 $3^{\underline{a}}$ hora; $5-13,5^{\mathrm{a}}$ hora (antes da indução); 6-1 hora induzido; 7-2 horas induzido; 8-3 horas induzido; 9-4 horas induzido.

$\mathrm{Na}$ figura 4.8, pode-se verificar no cultivo com glicose (caneletas de 2 a 5 em A) que não houve escape na produção da proteína antes da indução, devido ao fato de a glicose atuar sobre o Lac operon e reprimir a expressão do gene. Enquanto que, no cultivo com glicerol como fonte de carbono, a proteína parece ter sido produzida em baixa quantidade antes da indução.

Foi avaliada também a estabilidade do plasmídeo (Tabela 4.1) nos cultivos. O plasmídeo apresentou uma estabilidade acima de $95 \%$ durante o cultivo com glicose e acima de $97 \%$ com glicerol.

Tabela 4.1: Porcentagem de colônias resistentes à kanamicina durante o cultivo descontínuo de $E$. coli BL21(DE3)+pET37 ${ }^{+} /$rfpspA3.

\begin{tabular}{lcc}
\hline \multicolumn{2}{c}{ \% Colônias resistentes à kanamicina } \\
\hline \multicolumn{1}{c}{ Amostras } & Glicose & Glicerol \\
\hline Inóculo & 95,7 & 99,0 \\
Antes da indução & 95,7 & 100,0 \\
Após a indução & 95,0 & 100,0 \\
Final do cultivo & 100,0 & 97,0 \\
\hline
\end{tabular}




\subsubsection{Purificação de rfPspA3 dos cultivos descontínuos}

Com o intuito de quantificar a produção de rfPspA3 nos cultivos descontínuos com glicose e glicerol, foi feita uma primeira etapa de purificação em resina IMAC-sepharose empacotada e carregada com $\mathrm{Ni}^{+2}$.

De cada cultivo tomaram-se $110 \mathrm{~g}$ de massa úmida de células. As células foram lisadas em um homogeneizador contínuo de alta pressão em tampão Tris 25 $\mathrm{mM}$ pH 8,0 e $0,1 \%$ de Triton X-100 em presença de $1 \mathrm{mM}$ de PMSF e, posteriormente, o material foi centrifugado para clarificação do homogenato (clarificado). As etapas do processo de cromatografia estão descritas no item 3.4.8.1. Utilizou-se imidazol como eluente nas seguintes concentrações em cada etapa: equilíbrio $5 \mathrm{mM}$, lavagem $10 \mathrm{mM}$ e eluição $250 \mathrm{mM}$, sendo a limpeza feita com EDTA.

Foi feita a eletroforese SDS-PAGE das frações obtidas em cada etapa do processo cromatográfico de cada cultivo como mostra a Figura 4.9.

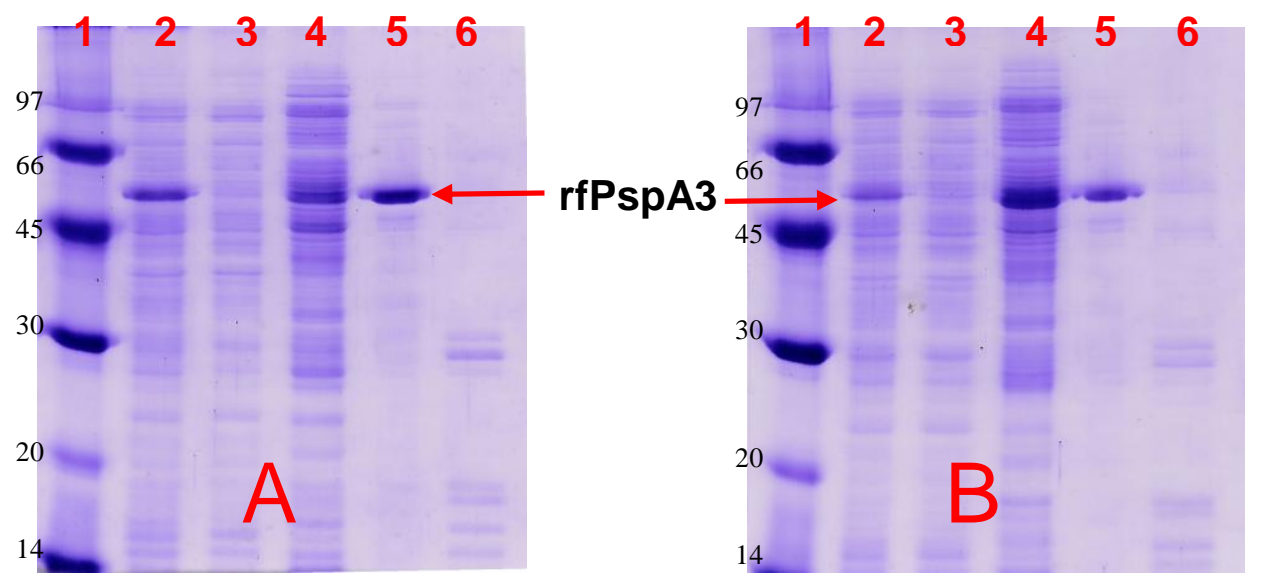

Figura 4.9: Gel de eletroforese com as frações obtidas na cromatografia IMAC-sepharose carregada com $\mathrm{Ni}^{+2}$ (com clarificados e eluições diluídos 10 vezes, fração não-adsorvida 5 vezes e lavagens sem diluição). A - Purificação a partir das células do cultivo em batelada com glicose. 1-Padrão de massa molecular $(\mathrm{kDa}), 2$-Clarificado centrifugado, 3-Fração nãoadsorvida, 4-Lavagem com $10 \mathrm{mM}$ de imidazol, 5-Eluição com 250mM de imidazol, 6Limpeza e regeneração da resina com EDTA. B - Purificação a partir das células do cultivo em batelada com glicerol. 1-Padrão Molecular (kDa), 2-Clarificado centrifugado, 3Fração não-adsorvida, 4-Lavagem com $10 \mathrm{mM}$ de imidazol, 5-Eluição com $250 \mathrm{mM}$ de imidazol, 6-Limpeza e regeneração da resina com EDTA.

Observa-se pela Figura 4.9 que a fração de eluição da purificação feita com as células provenientes do cultivo com glicose (caneleta $5 \mathrm{~A}$ ) apresentou uma maior concentração do rfPspA3, o que pode ser confirmado pela Tabela 4.2. Não houve grande perda de rfPspA3 na fração não-adsorvida e na fração lavagem, além disso, 
essa última fração foi responsável pela remoção de uma quantidade significativa de impurezas, as quais seriam eluídas juntamente com o rfPspA3 caso a lavagem não fosse realizada.

Através dessas eletroforeses foram feitas densitometrias para determinar a pureza e quantificar o rfPspA3. A Tabela 4.2 apresenta os resultados da densitometria.

Tabela 4.2: Comparação do rfPspA3 obtido nos cultivos descontínuos após a cromatografia de afinidade por metal.

\begin{tabular}{lcc}
\hline & Cultivo Glicose & Cultivo Glicerol \\
\hline Proteínas Totais (mg) & 1860,9 & 932,8 \\
Pureza do rfPspA3 (\%)* & 78,8 & 78,2 \\
Fator de Purificação & 2,9 & 3,9 \\
rfPspA3 na fração de eluição (mg)** & 1455,2 & 735,1 \\
Produção Volumétrica (g/L) & 0,72 & 0,47 \\
\hline${ }^{*}$ Dados obtidos da densitometria dos géis de eletroforese & SDS-PAGE & (Figuras 4.9 A e \\
B).**alculado como: pureza x proteínas totais (mg)/100. &
\end{tabular}

Nota-se pelos resultados da tabela 4.2 que a produção volumétrica de rfPspA3 foi $35 \%$ maior no cultivo com glicose. Apesar de este resultado ter sido obtido de uma fração purificada, as perdas ocorridas nas demais frações da cromatografia foram muito semelhantes: 5,6 e 5,4\% na fração não-adsorvida e 9,0 e $7,0 \%$ na lavagem dos cultivos com glicose e com glicerol respectivamente. Além disso, a pureza alcançada nesta etapa foi muito semelhante entre o material proveniente dos dois cultivos, aproximadamente $78 \%$. No cultivo com glicerol o fator de purificação foi maior porque a pureza do material de partida, o clarificado, foi menor: $20,2 \%$ contra $26,6 \%$ do clarificado obtido do cultivo com glicose.

Uma possível razão para que o cultivo em glicerol tenha levado a maior produtividade celular, porém menor produção de rfPspA3 seria o fato de a razão IPTG/ células não ter sido suficiente para induzir todas as células do cultivo, pois no cultivo com glicerol esta razão foi menor que no cultivo com glicose: no momento da indução havia $8,5 \mathrm{~g} / \mathrm{L}$ de células no cultivo com glicose e 12,6 $\mathrm{g} / \mathrm{L}$ no cultivo com glicerol. Outro fato importante a ser notado é que, após 4 horas de indução, a lactose não foi totalmente consumida nos dois cultivos (Figuras 4.6 e 4.7) o que indica a necessidade de um tempo de indução maior para que todas as células 
fossem induzidas, o que levaria a uma maior produção volumétrica de rfPspA3. Assim, uma amostra do cultivo descontínuo alimentado foi empregada para estudar a relação IPTG/ células e IPTG/ tempo de indução com o intuito de definir uma relação que levasse à maior produção da proteína de interesse.

\subsubsection{Cultivo Descontínuo Alimentado de E. coli BL21(DE3) para produção de rfPspA3 em biorreator de $5 \mathrm{~L}$}

Determinados os parâmetros cinéticos em cultivo descontínuo, o estudo em descontínuo alimentado foi feito utilizando a vazão de alimentação descrita pela Equação 3.1 do item 3.3.4.2. No cultivo descontínuo, o uso de glicerol como fonte de carbono apresentou maior produção celular e menor produção de acetato que o cultivo em glicose, enquanto que a produção volumétrica de rfPspA3 foi maior no cultivo com glicose. Como isso poderia ser decorrente de uma relação inadequada IPTG/células, decidiu-se realizar cultivos descontínuos alimentados utilizando novamente as duas fontes de carbono. As Figuras 4.10 e 4.11 mostram os resultados do cultivo descontínuo alimentado com glicose e glicerol, respectivamente, como fonte de carbono.

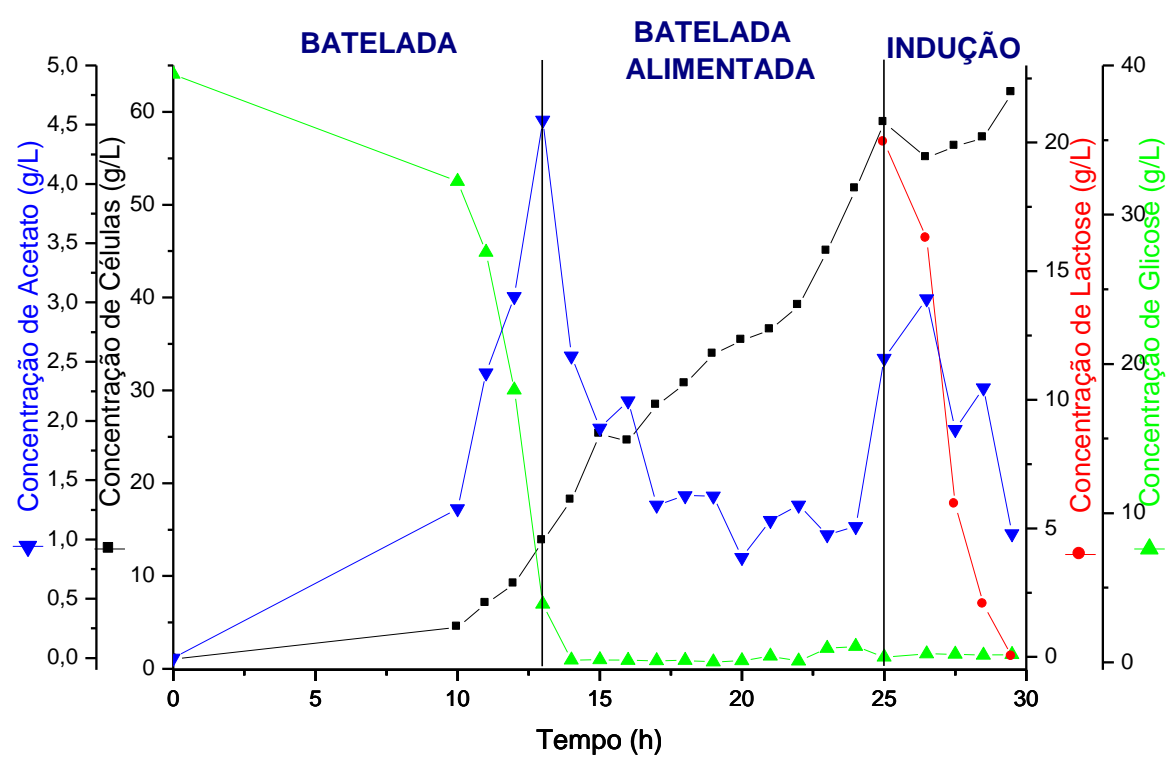

Figura 4.10: Cultivo descontínuo alimentado de E. coli BL21(DE3) para produção de rfPspA3 com glicose como fonte de carbono. Perfil do consumo de glicose ( - ), do consumo de lactose ( - ), do crescimento celular ( - ), e da produção de ácido acético $(-\boldsymbol{\nabla})$. 


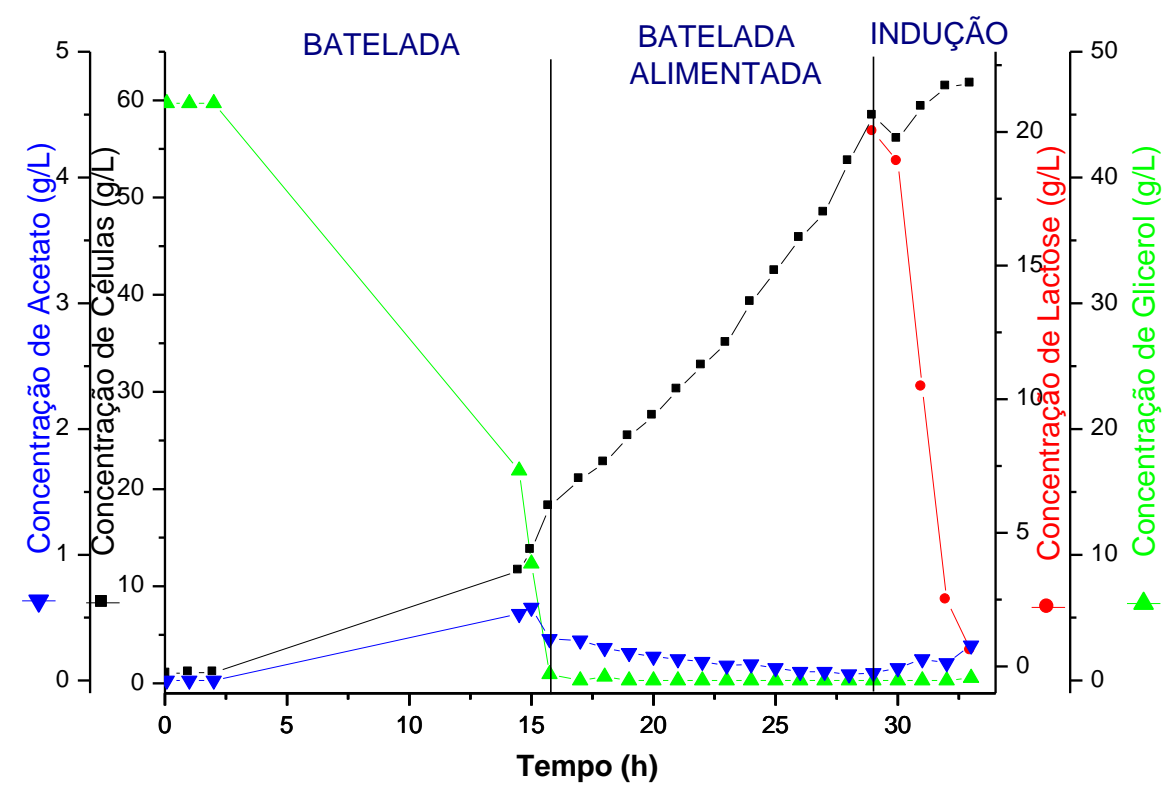

Figura 4.11: Cultivo descontínuo alimentado de E. coli BL21(DE3) para produção de rfPspA3 com glicerol como fonte de carbono. Perfil do consumo de glicose ( - ), do consumo de lactose ( - ), do crescimento celular $(-\square)$ ), e da produção de ácido acético $(-\nabla)$.

De acordo com o gráfico mostrado na Figura 4.10 podemos verificar que a fase descontínua do cultivo com glicose foi um pouco mais longa que a do cultivo anterior (Figura 4.6) e a produção de acetato foi maior, passando de 2,2 para 4,5 $\mathrm{g} / \mathrm{L}$. Isto se deveu ao fato de que a concentração inicial de glicose mais elevada ocasionou maior produção de acetato e conseqüentemente a velocidade máxima de crescimento celular diminuiu, chegando a $0,41 \mathrm{~h}^{-1}$, enquanto que na produção em cultivo descontínuo foi $0,53 \mathrm{~h}^{-1}$. Além disso, segundo Gnoth et al., dependendo do valor da concentração inicial de glicose a inibição do crescimento celular pelo substrato pode ocorrer, pois, o substrato em alta concentração provoca uma maior produção de subprodutos que inibem o crescimento ${ }^{46}$. Porém, esses fatos não impediram que a produtividade em células atingisse 1,06 $\mathrm{g} / \mathrm{L}$.h na fase descontínua deste cultivo contra $0,77 \mathrm{~g} / \mathrm{L} . \mathrm{h}$ do processo descontínuo anterior.

No cultivo com glicerol como fonte de carbono (Figura 4.11) foi obtida uma velocidade de crescimento de $0,38 \mathrm{~h}^{-1}$ na fase descontínua, semelhante à obtida no cultivo descontínuo $\left(0,40 \mathrm{~h}^{-1}\right)$ e no cultivo descontínuo alimentado com glicose. Como constatado no cultivo descontínuo, no descontínuo alimentado a produção de acetato com glicerol foi menor do que no cultivo com glicose como fonte de carbono, 
não chegando a $1,0 \mathrm{~g} / \mathrm{L}$ durante toda essa etapa de produção. A produtividade celular na etapa descontínua chegou a $1,15 \mathrm{~g} / \mathrm{L} . \mathrm{h}$ superando a do cultivo descontínuo com glicerol (0,74 g/L.h) e também os cultivos descontínuo e descontínuo alimentado com glicose. Entretanto, no final do cultivo foi obtido $1,87 \mathrm{~g} / \mathrm{L}$.h de produtividade celular, abaixo dos 2,10 g/L.h obtido do cultivo com glicose como fonte de carbono. Segundo Shiloach e Fass, uma concentração celular acima de $50 \mathrm{~g} / \mathrm{L}$ é considerada alta densidade celular, sendo possível, atualmente, alcançar no máximo em torno de $200 \mathrm{~g} / \mathrm{L}$, pois, acima desse valor a cultura de E. coli perde a fluidez. Nesse trabalho foram alcançados os valores de 62,05 g/L e 61,71 $\mathrm{g} / \mathrm{L}$ nos cultivos com glicose e glicerol, respectivamente, como fonte de carbono no início da indução. Pinsach et al. ${ }^{24} \mathrm{em}$ seu trabalho com cultivo descontínuo alimentado iniciou a indução com uma $\mathrm{DO}_{600 \mathrm{~nm}}$ de $E$. coli M15 em torno de 150, e após a indução, eles constataram que houve crescimento celular chegando a 200 de $\mathrm{DO}_{600 \mathrm{~nm}}$ e diminuindo ao fim de 6 horas de indução para 150.

Após a fase descontínua, quando acaba a fonte de carbono, o acetato começa a ser consumido pela bactéria até que sua concentração fique estável durante a alimentação e voltando a aumentar durante a indução, provavelmente devido ao estresse celular nesse momento do processo.

Após 25 horas de cultivo com glicose e 29 horas com glicerol, foi feita a indução, pois a $\mathrm{DO}_{600 n m}$ começou a se estabilizar. Nesse momento adicionou-se a lactose, que foi consumida totalmente ao final de 4 horas de indução, diferente do processo descontínuo, no qual ao final do processo ainda restava lactose. Isto se deveu à maior concentração celular no biorreator ao final do cultivo descontínuo alimentado em relação ao cultivo descontínuo.

Foi avaliada também a produção de rfPspA3 dos cultivos por eletroforese SDS-PAGE como mostra a Figura 4.12. 


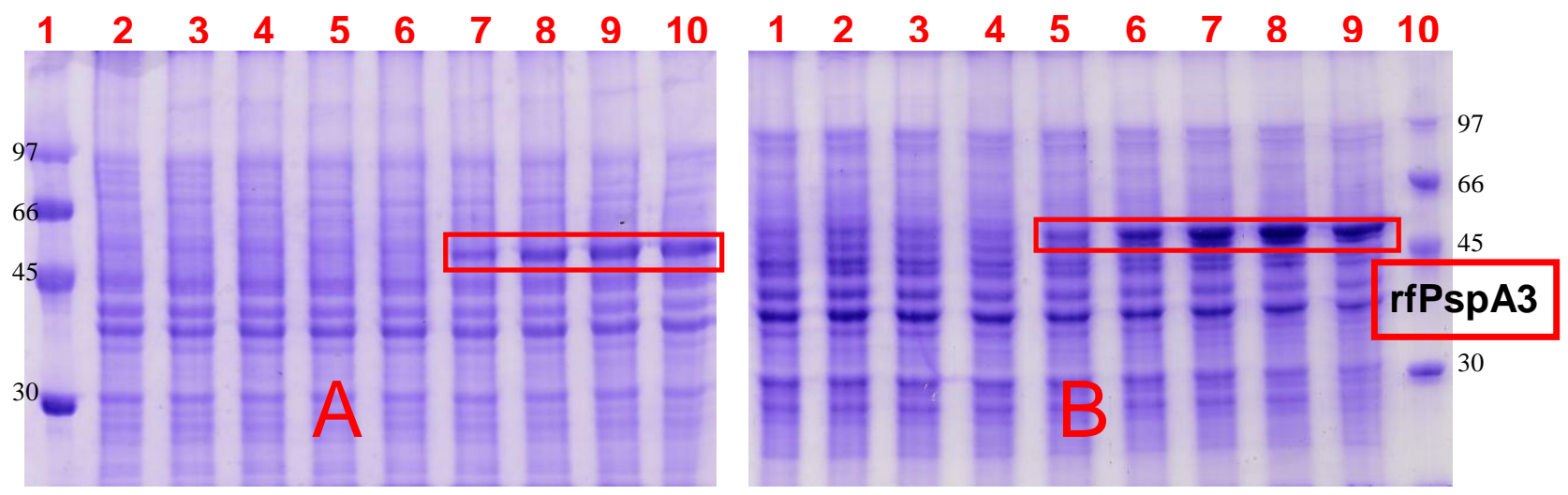

Figura 4.12: Gel de eletroforese de rfPspA3 das amostras do cultivo descontínuo alimentado com glicose (A) e glicerol (B) como fonte de carbono. A: 1-Padrão de massa molecular em $\mathrm{kDa} ; 2-21^{\underline{a}}$ hora do cultivo; $3-22^{\mathrm{a}}$ hora do cultivo; $4-23^{\mathrm{a}}$ hora do cultivo; $5-24^{\mathrm{a}}$ hora do cultivo; 6-25a hora do cultivo (antes da indução); 7-1 hora de indução; 8-2 horas de indução; 9-3 horas de indução; 10-4 horas de indução. B: 1-26 hora do cultivo; 3-28 ${ }^{\text {a }}$ hora do cultivo; 4-29a hora do cultivo (antes da indução); 5-1 hora de indução; 6-2 horas de indução; 7-3 horas de indução; 8-4 horas de indução; 9-4 horas de indução; 10-Padrão de massa molecular em kDa.

De acordo com a Figura 4.12, verifica-se que houve produção crescente de rfPspA3 durante a fase de indução nos dois cultivos. Não houve escape da expressão do gene antes da indução no cultivo com glicose como fonte de carbono, porém a proteína foi produzida em baixa quantidade no cultivo com glicerol como fonte de carbono, assim como no cultivo descontínuo. No cultivo descontínuo alimentado esse valor chegou a $\sim 7,0 \%$ uma hora antes da indução. A estabilidade do plasmídeo manteve-se em $100 \%$ durante todo o cultivo com glicose e acima de $88 \%$ no cultivo com glicerol.

Estimou-se através da densitometria das bandas dos géis de eletroforese que, ao final dos processos, foi obtido $22,1 \%$ de rfPspA3 no cultivo utilizando glicose como fonte de carbono e 20,8\% utilizando glicerol (Figura 4.12, B, caneletas 8 e 9). Observa-se que a produção foi muito semelhante nos dois casos, por isso o cultivo com glicose foi melhor em produtividade de rfPspA3 (o mesmo foi produzido em menor tempo), chegando a 0,12 g/L.h com glicose e 0,09 g/L.h com glicerol.

\subsubsection{Estudo da relação IPTG/ células/ tempo de indução}

Depois de verificada, pelos cultivos descontínuos, a necessidade de definir as relações entre IPTG/células/tempo de indução, células do cultivo descontínuo alimentado com glicose como fonte de carbono foram retiradas, antes 
da indução, para a realização de testes em frascos agitados. Foram feitas duas séries de testes, uma variando a concentração de células e a outra a de IPTG, todas analisadas em 4 e 12 horas de indução.

Variando a concentração celular, medida por $\mathrm{DO}_{600 \mathrm{~nm}}$, foram feitos dois tipos de análises:

1 - Aplicado ao SDS-PAGE uma quantidade de células correspondentes a $\mathrm{DO}_{600 \mathrm{~nm}}$ igual a 5,0 para todas as amostras;

2- Aplicado ao SDS-PAGE volume constante das amostras (2 $\mu \mathrm{L})$, independentemente da quantidade de células contida neste volume.

Abaixo as figuras 4.13 e 4.14 (A e B) mostram a produção de rfPspA3 nas amostras cuja $\mathrm{DO}_{600 \mathrm{~nm}}$ variou nos dois tempos de indução.

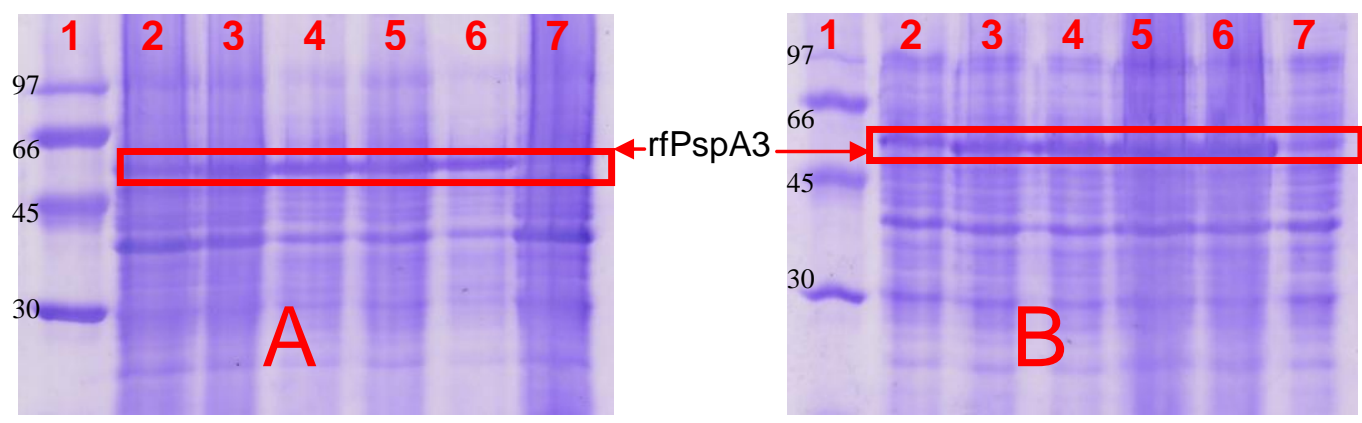

Figura 4.13: Eletroforese de rfPspA3 produzido por E. coli BL21(DE3) dos testes da relação IPTG/células/tempo de indução com concentração de IPTG $1 \mathrm{mM} /$ lactose $16 \mathrm{~g} / \mathrm{L}$ e variação de $\mathrm{DO}_{600 \mathrm{~nm}}$. Cada amostra foi ajustada em $\mathrm{DO}_{600 \mathrm{~nm}}$ igual a cinco para aplicação ao gel. 1-Padrão de massa molecular em kDa; $2-\mathrm{DO}_{600 \mathrm{~nm}}=140 ; 3-\mathrm{DO}_{600 \mathrm{~nm}}=$ $70 ; 4-\mathrm{DO}_{600 \mathrm{~nm}}=35 ; 5-\mathrm{DO}_{600 \mathrm{~nm}}=17,5 ; 6-\mathrm{DO}_{600 \mathrm{~nm}}=8,75 ; 7-\mathrm{DO}_{600 \mathrm{~nm}}=140 \mathrm{sem}$ IPTG (controle). A - 4 horas de indução e $B-12$ horas.

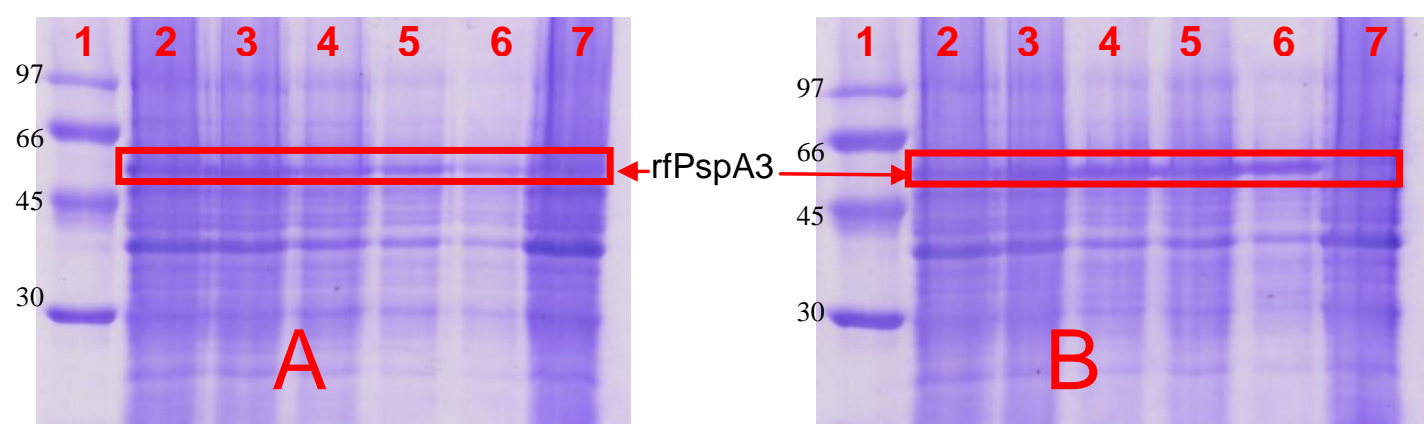

Figura 4.14: Eletroforese de rfPspA3 produzido por E. coli BL21(DE3) dos testes da relação IPTG/células/tempo de indução com concentração de IPTG $1 \mathrm{mM} /$ lactose $16 \mathrm{~g} / \mathrm{L}$ e variação de $\mathrm{DO}_{600 \mathrm{~nm}}$. Foi aplicado ao gel $2 \mu \mathrm{L}$ de cada amostra . 1-Padrão de massa molecular em kDa; $2-\mathrm{DO}_{600 \mathrm{~nm}}=140 ; 3-\mathrm{DO}_{600 \mathrm{~nm}}=70 ; 4-\mathrm{DO}_{600 \mathrm{~nm}}=35 ; 5-\mathrm{DO}_{600 \mathrm{~nm}}=17,5$; $6-\mathrm{DO}_{600 \mathrm{~nm}}=8,75 ; 7-\mathrm{DO}_{600 \mathrm{~nm}}=140$ sem IPTG (controle). A -4 horas de indução e B 12 horas. 
Assim como no teste anterior, foram feitos dois géis de eletroforese para análise do efeito de diferentes concentrações de IPTG para indução em 4 e 12 horas. A figura 4.15 apresenta esses resultados.

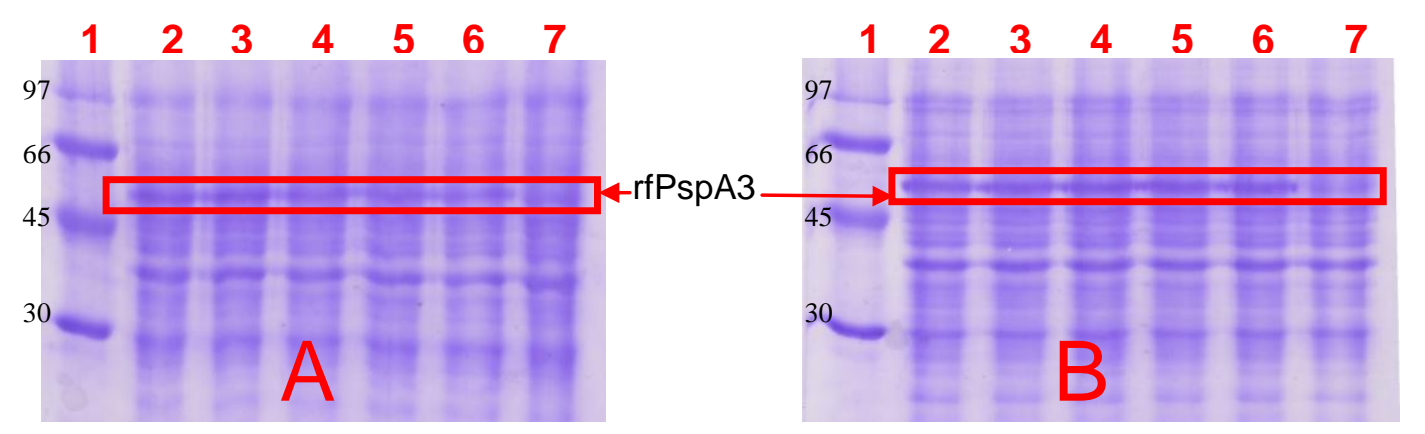

Figura 4.15: Eletroforese de rfPspA3 produzido por E. coli BL21(DE3) dos testes da relação IPTG/células/tempo de indução com concentração celular fixa $\left(\mathrm{DO}_{600 \mathrm{~nm}}=140\right)$, lacose $16 \mathrm{~g} / \mathrm{L}$ e variação da concentração de IPTG. Para cada teste, uma quantidade de células correspondente a $\mathrm{DO}_{600 \mathrm{~nm}}$ igual a cinco foi aplicada ao gel. 1-Padrão de massa molecular em kDa; 2-0,5 mM de IPTG; 3-1,0 mM de IPTG; 4-1,5 mM de IPTG; 5-2,0 mM de IPTG; 6-2,5 mM de IPTG; 7-0,0 mM de IPTG (controle). A - 4 horas de indução e $\mathrm{B}-12$ horas.

Verificou-se em todas as amostras analisadas que houve produção do rfPspA3, inclusive nas amostras controle sem IPTG. Isto aconteceu devido à presença de lactose adicionada em todos os frascos. Abaixo estão os perfis da concentração de rfPspA3 nos testes realizados mostrados nas Figuras 4.16, $4.17 \mathrm{e}$ 4.18. Esses valores foram calculados por densitometria das áreas das bandas de rfPspA3 dos géis de eletroforese das figuras acima.

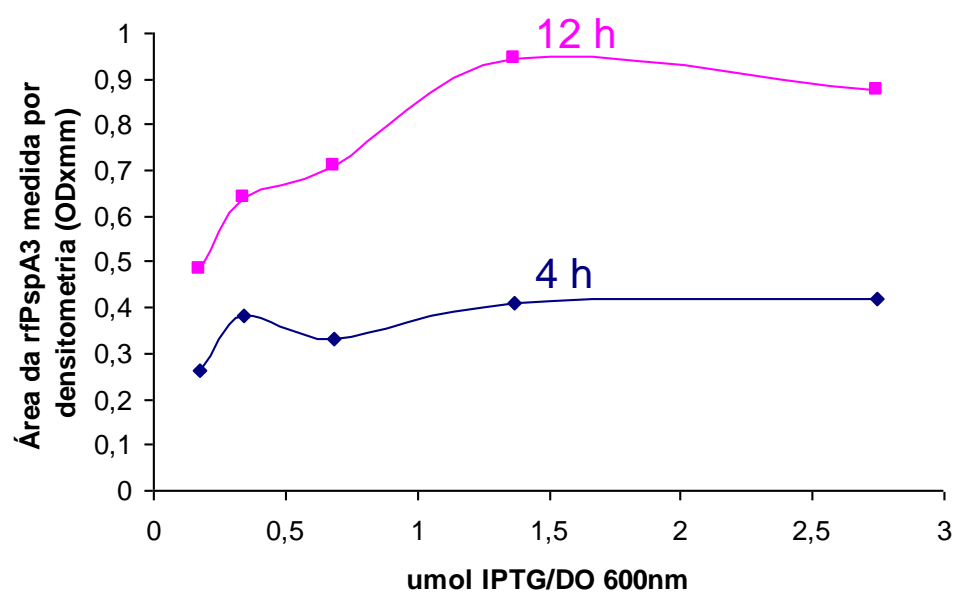

Figura 4.16: Perfil de produção de rfPspA3 em teste da relação IPTG/células/tempo de indução com concentração de IPTG $1 \mathrm{mM} /$ lactose $16 \mathrm{~g} / \mathrm{L}$. Área da banda do rfPspA3 (SDS-PAGE Figura 4.13) versus relação $\mu \mathrm{mol}$ IPTG/DO $600 \mathrm{~nm}$. SDS-PAGE de amostras com quantidade de células correspondentes à $\mathrm{DO}_{600 \mathrm{~nm}}=5,0$. (- -4 horas de indução e $(-+)$ 12 horas de indução. 


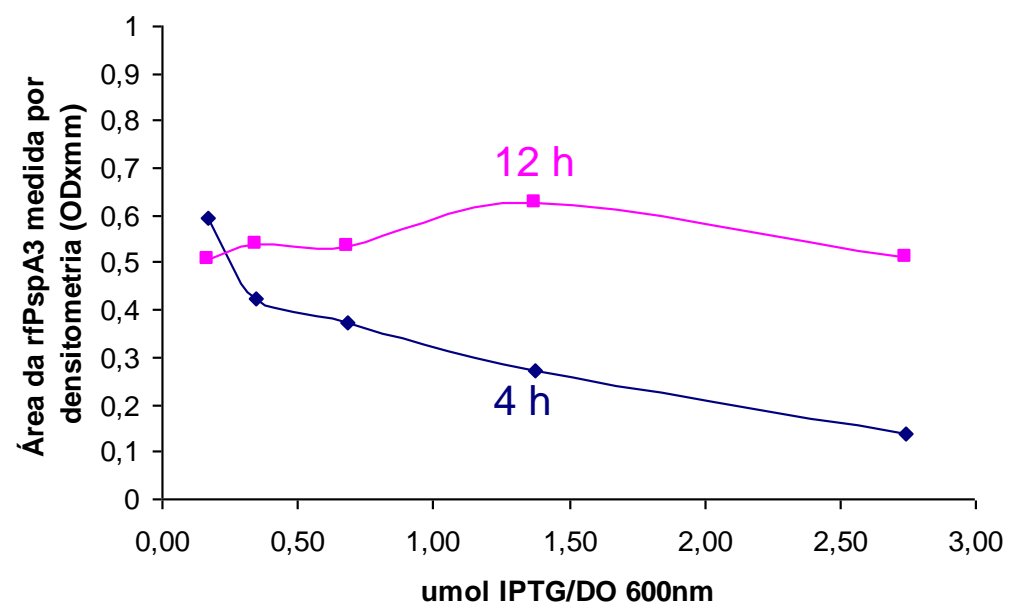

Figura 4.17: Perfil de produção de rfPspA3 em teste da relação IPTG/células/tempo de indução com concentração de IPTG $1 \mathrm{mM} /$ /lactose $16 \mathrm{~g} / \mathrm{L}$ e variação da concentração celular. Área da banda do rfPspA3 (SDS-PAGE - Figura 4.14) versus relação $\mu \mathrm{mol}$ IPTG/DO $600 \mathrm{~nm}$. SDSPAGE de amostras com volume de $2 \mu \mathrm{L}$. (-) 4 horas de indução e (- $\left(^{-}\right) 12$ horas de indução.

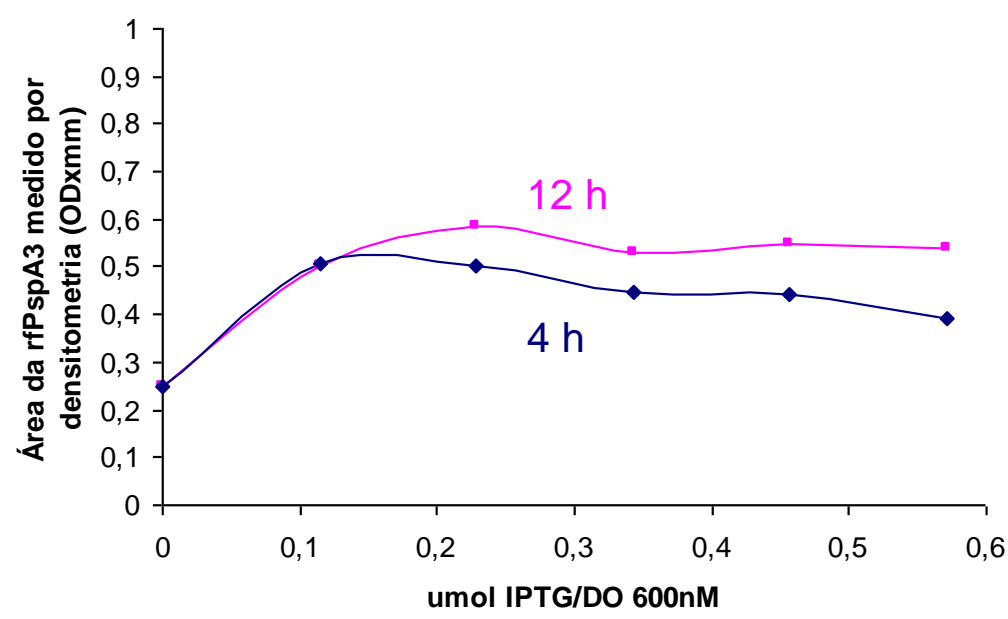

Figura 4.18: Perfil de produção de rfPspA3 em teste da relação IPTG/células/tempo de indução com concentrações fixas de células $\left(D_{600 \mathrm{~nm}}=140\right)$ e lactose $16 \mathrm{~g} / \mathrm{L}$ e variação da concentração de IPTG analisado pela eletroforese SDS-PAGE (Figura 4.15). SDS-PAGE de amostras com quantidade de células correspondentes à $\mathrm{DO}_{600 \mathrm{~nm}}=5,0$. $(-\downarrow) 4$ horas de indução e (- $(-) 12$ horas de indução.

Considerando-se que, quanto maior a área da banda de $\operatorname{rfPspA3}$, maior a quantidade dessa proteína na amostra, observou-se que, em todos os testes, foi obtida maior quantidade de proteína com 12 horas de indução.

De acordo com a Figura 4.16, a razão necessária de IPTG/células em 12 horas de indução foi maior do que quando se induziu por 4 horas, pois, a curva no tempo menor atingiu um patamar com menor valor da relação entre IPTG e DO $600 \mathrm{~nm}$ 
( 0,34 $\mu \mathrm{mol}$ IPTG/DO $\left.{ }_{600 \mathrm{~nm}}\right)$ do que em 12 horas de indução $(\sim 1,3 \mu \mathrm{mol}$ IPTG/DO ${ }_{600 \mathrm{~nm}}$ ). Na Figura 4.17 o valor da área de rfPspA3 começou a decair quando se aumentou a razão IPTG/células, isto aconteceu porque foi aplicado ao gel o mesmo volume de cada amostra, ou seja, a quantidade de células aplicada ao gel diminuiu com o aumento relação IPTG/DO $\mathrm{D}_{600 \mathrm{~nm}}$, e, consequentemente, diminuiu também a área da proteína produzida.

Ao analisar amostras com variação do valor de IPTG (Figura 4.18), verificou-se que com 12 horas de indução, $\sim 0,23 \mu \mathrm{mol}$ IPTG/DO ${ }_{600 \mathrm{~nm}}$ foi suficiente para a indução e, com 4 horas $\sim 0,11 \mu \mathrm{mol}$ IPTG/DO ${ }_{600 \mathrm{~nm}}$, valores bem menores do que os obtidos quando se variou a concentração de células no meio. Isto pode ser, provavelmente, devido às condições do experimento em frascos agitados, pois, alguma outra variável não analisada poderia estar interferindo nos resultados, como por exemplo, a transferência de oxigênio no meio, pois esta é bem menor em frascos do que em biorreatores. A limitação de oxigênio leva a menor obtenção de energia pelas células, e pode afetar a síntese protéica. 


\subsection{CARACTERÍSTICAS DO rfPspA3}

De acordo com a sequência do fragmento recombinante da PspA3, mostrada na Figura 4.19, foram obtidas as características físico-químicas deste fragmento empregando-se um programa disponível no site $^{36}$.

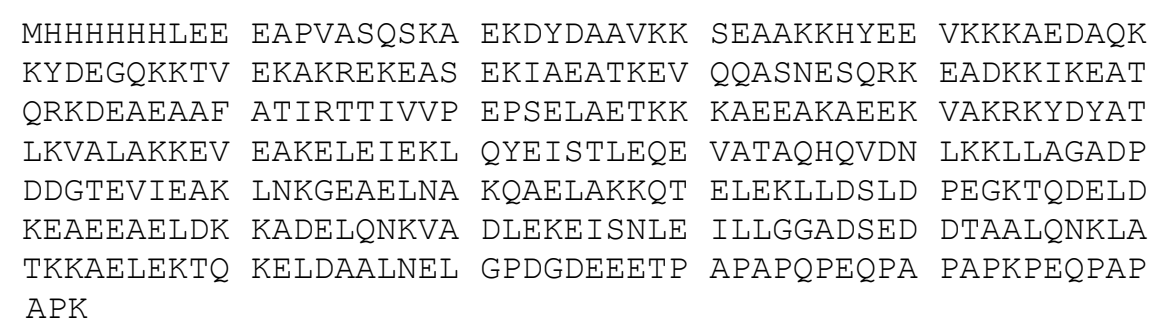

Figura 4.19: Sequência do fragmento recombinante da PspA3 utilizado neste trabalho.

A partir da análise da seqüência do rfPspA3 foram obtidas as seguintes características físico-químicas:

Número de aminoácidos: 353

Massa molecular: $39125,18 \mathrm{Da}$

Absorção $0,1 \%(1 \mathrm{~g} / \mathrm{L})$ à $280 \mathrm{~nm}(1 \mathrm{~cm}): 0,196$

Ponto isoelétrico teórico: 4,74

Através da seqüência foi possível determinar a composição de aminoácidos do rfPspA3. A Tabela 4.3 mostra a composição, número de aminoácidos e sua porcentagem. 
Tabela 4.3: Composição de aminoácidos do rfPspA3 obtida pela análise de sua seqüência pelo programa.

\begin{tabular}{lcc}
\hline Aminoácido & $\begin{array}{c}\text { No de } \\
\text { aminoácidos }\end{array}$ & $\begin{array}{c}\text { Porcentagem } \\
\text { de aminoácidos }\end{array}$ \\
\hline Alanina (A) & 55 & 15,58 \\
Arginina (R) & 5 & 1,42 \\
Ácido Aspártico (N) & 8 & 2,27 \\
Asparagina (D) & 24 & 6,80 \\
Cisteína (C) & 0 & 0,00 \\
Glutamina (Q) & 20 & 5,67 \\
Ácido glutâmico (E) & 62 & 17,56 \\
Glicina (G) & 9 & 2,55 \\
Histidina (H) & 8 & 2,27 \\
Isoleucina (I) & 9 & 2,55 \\
Leucina (L) & 30 & 8,50 \\
Lisina (K) & 56 & 15,86 \\
Metionina (M) & 1 & 0,28 \\
Fenilanina (F) & 1 & 0,28 \\
Prolina (P) & 17 & 4,82 \\
Serina (S) & 11 & 3,12 \\
Treonina (T) & 17 & 4,82 \\
Triptofano (W) & 0 & 0,00 \\
Tirosina (Y) & 6 & 1,70 \\
Valina (V) & 14 & 3,97 \\
\hline
\end{tabular}

Foi calculada pelo mesmo site uma curva de titulação teórica como mostra a Figura 4.20.

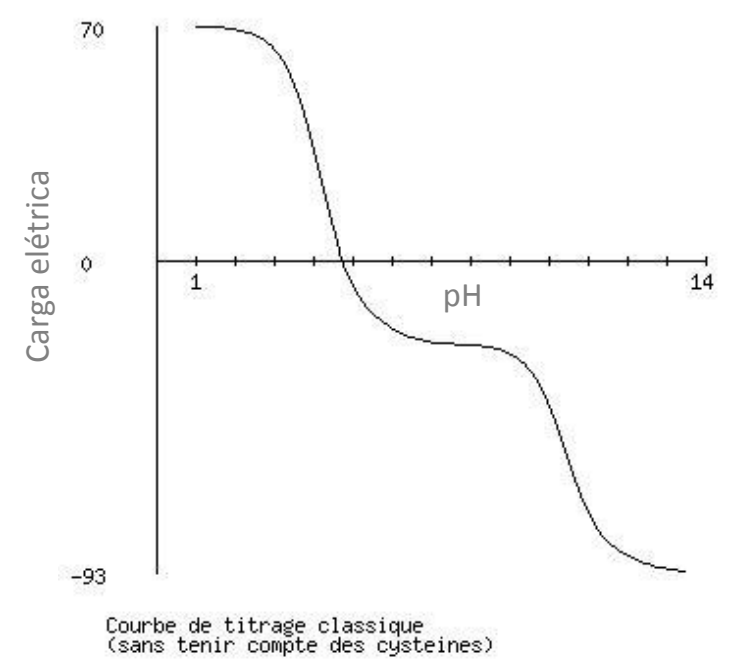

Figura 4.20: Curva de titulação teórica do rfPspA3 obtido do programa.

Essas características foram importantes para a definição dos parâmetros utilizados durante as etapas de purificação, bem como para análise dos resultados obtidos. 


\subsection{DESENVOLVIMENTO DO PROCESSO DE PURIFICAÇÃO DO rfPspA3}

\subsubsection{Separação das células do meio de cultivo}

Após a finalização dos cultivos, as células foram separadas do meio por centrifugação. A Tabela 4.4 mostra a quantidade de massa celular úmida produzida em cada cultivo e também o volume final de cultivo.

Tabela 4.4: Dados finais dos cultivos em biorreator de $5 \mathrm{~L}$ após separação das células do meio de cultivo.

\begin{tabular}{cccccc}
\hline \multirow{2}{*}{ Cultivo } & $\begin{array}{c}\text { Fonte de } \\
\text { carbono }\end{array}$ & $\begin{array}{c}\text { Volume } \\
\text { final (L) }\end{array}$ & $\begin{array}{c}\text { Massa } \\
\text { celular úmida } \\
\text { final } \mathbf{( g )}\end{array}$ & $\begin{array}{c}\text { Concentração } \\
\text { celular final } \\
(\mathbf{g} / \mathbf{L})^{*}\end{array}$ & $\begin{array}{c}\text { Produtividade } \\
\text { celular }(\mathbf{g} / \mathbf{L} . \mathbf{h})^{\star}\end{array}$ \\
\hline \multirow{2}{*}{ Descontínuo } & Glicose & 4,70 & 257,3 & 10,7 & 0,7 \\
& Glicerol & 5,04 & 352,6 & 13,0 & 0,7 \\
\hline Descontínuo & Glicose & 5,00 & 1362,5 & 62,0 & 2,1 \\
Alimentado & Glicerol & 4,82 & 1194,7 & 61,7 & 1,9 \\
\hline
\end{tabular}

*massa seca

De acordo com os dados da Tabela 4.4, podemos observar que a quantidade de biomassa gerada nos cultivos descontínuo alimentados foi aproximadamente 6 vezes superior à obtida nos cultivos descontínuos, o mesmo ocorrendo com sua concentração celular final. A quantidade de sólidos em suspensão dos cultivos descontínuos alimentados foi cerca de 30\%, o que inviabiliza o uso de membranas de microfiltração nesta etapa.

\subsubsection{Lise celular}

Para todos os testes foram lisados $\sim 103 \mathrm{~g}$ de massa celular úmida proveniente dos cultivos descontínuo alimentados com glicose como fonte de carbono e também com glicerol. A lise foi realizada em $1000 \mathrm{~mL}$ de tampão de lise. Em 10 minutos de lise contínua foram analisadas amostras a cada minuto, o que correspondeu a 1 amostra por ciclo, pois a vazão é de $60 \mathrm{~L} / \mathrm{h}$, ou seja, $1 \mathrm{~L} / \mathrm{min}$. Portanto, o volume total passado no homogeneizador foi determinado como 1 ciclo, o que nesse caso levou 1 minuto para ser realizado. As análises foram feitas por 
espectrofotometria a $600 \mathrm{~nm}$, plaqueamento e por quantificação de produto obtido (proteínas totais e rfPspA3). As amostras foram centrifugadas e o sobrenadante analisado. A Figura 4.21 mostra a eletroforese feita com este sobrenadante.
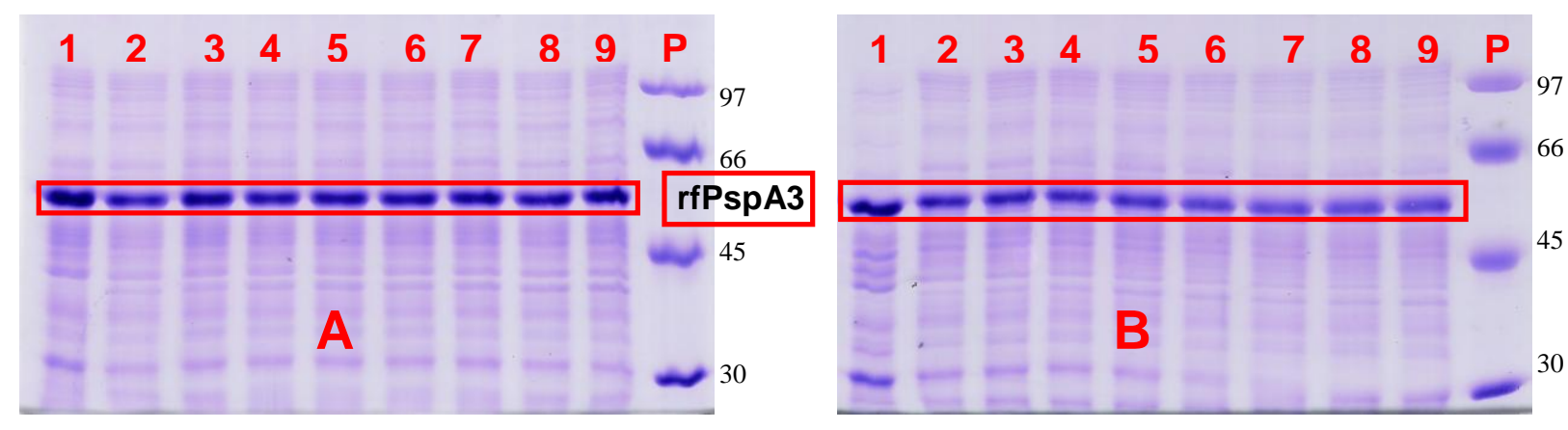

Figura 4.21: Géis de eletroforese do sobrenadante das amostras da lise celular mecânica em homogeneizador de alta pressão APV Gauling 60. A-Lise celular do cultivo com glicose como fonte de carbono e B-Lise celular do cultivo com glicerol com fonte de carbono. Amostras aplicadas com $10 \mu \mathrm{g}$ de proteínas totais. P-Padrão de massa molecular $(\mathrm{kDa})$; 1-Amostra inicial da lise; 2-Após 1 minuto de lise; 3-Após 2 minutos; 4-Após 3 minutos; 5-Após 4 minutos; 6-Após 5 minutos; 7-Após 6 minutos; 8-Após 8 minutos; 9Após 10 minutos (final da lise).

Verificou-se através da Figura 4.21 que havia presença de rfPspA3 em maior proporção em todas as amostras analisadas no gel ( $30 \%$ por análise de densitometria). Sua presença inicial indicou que houve lise antes do início da operação no homogeneizador de alta pressão, provavelmente devido à presença do detergente Triton $X-100$, que mesmo em baixa concentração $(0,1 \%)$ foi responsável por lise química da célula. Alguns trabalhos utilizaram este detergente só ou associado a outros produtos químicos para extrair proteínas de células gramnegativas com lise mecânica ${ }^{47}$ ou mesmo sem lise mecânica para extração de RNAs de baixo peso molecular ${ }^{48}$. Mesmo assim, a ruptura celular de E. coli por processo mecânico em homogeneizador de alta pressão demonstrou resultados de maior eficiência chegando a $100 \%{ }^{49}$, sendo que utilizando somente lise química esse fator chegou a $95 \%{ }^{47}$.

A Figura 4.22 A e B mostra o resultado de proteínas totais no sobrenadante (A) e concentração de rfPspA3 no sobrenadante (B) obtido através da densitometria dos géis de eletroforese da Figura 4.21 A e $B$, respectivamente. 

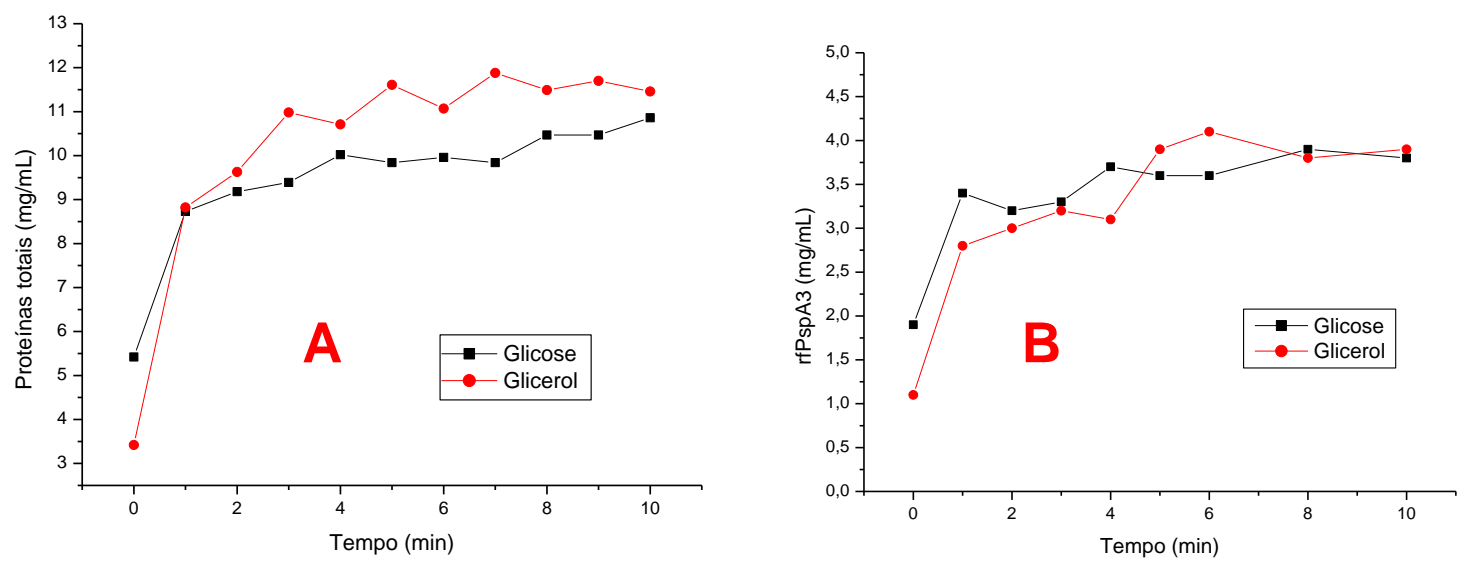

Figura 4.22: Perfil da concentração de proteínas totais $(A)$ e rfPspA3 (B) obtido em relação ao tempo de lise das células obtidas dos cultivos de alta densidade com glicose como fonte de carbono ( - -) e com glicerol ( $-\boldsymbol{-})$.

Observa-se pela Figura 4.22 que após 6 minutos de lise (6 ciclos) para a lise do cultivo com glicose e 7 minutos (7 ciclos) para a lise do cultivo com glicerol alcançaram-se um patamar, indicando que não houve aumento na concentração de proteínas chegando, no final deste processo, em $\sim 11,0 \mathrm{mg} / \mathrm{mL}$ de proteínas totais e $\sim$ 3,75 mg/mL de rfPspA3 nas duas lises realizadas. Utilizando glicerol como fonte de carbono no cultivo, a quantidade inicial de proteínas totais em sua lise foi menor. Isto ocorreu, provavelmente, porque o glicerol teve função crioprotetora e evitou que as células lisassem durante o descongelamento. Porém, ao fim desta etapa a concentração de proteínas totais chegou a praticamente o mesmo valor com 5,0\% a mais para as células provindas do cultivo com glicerol. Para a concentração de rfPspA3 ao final do processo o mesmo valor foi encontrado para as duas lises realizadas $(3,9 \mathrm{mg} / \mathrm{mL})$. Goyal et al $^{50}$ estudando a expressão e purificação de streptoquinase em E. coli BL21(DE3) encontrou $1,08 \mathrm{mg} / \mathrm{mL}$ desta proteína produzida em cultivo de alta densidade e, posteriormente, em outro trabalho, na tentativa de aperfeiçoar estudos dos parâmetros de cultivo em alta densidade, estes mesmos autores conseguiram chegar $1,12 \mathrm{mg} / \mathrm{mL}^{51}$.

A integridade celular também foi analisada através da contagem de unidades formadoras de colônias (UFC/mL) em placas de meio LB Agar e também por $\mathrm{DO}_{600 \mathrm{~nm}}$. A Figura 4.23 apresenta esses resultados. 


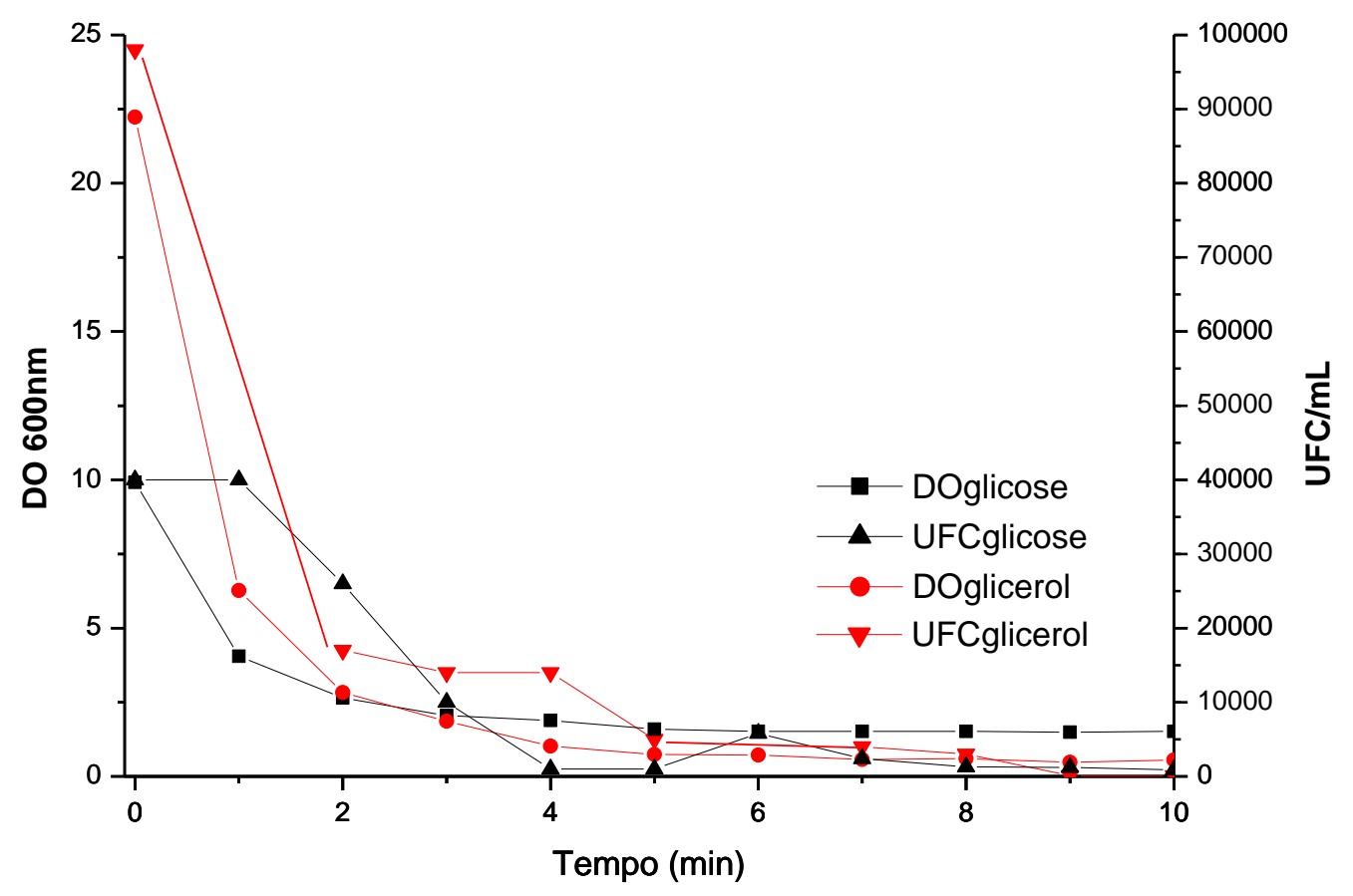

Figura 4.23: Perfil de $\mathrm{DO}_{600 n m}$ e de contagem de colônias pelo tempo de lise celular em homogeneizador de alta pressão Gaulin APV 60. Amostras a partir das células do cultivo em alta densidade com glicose como fonte de carbono analisadas por $\mathrm{DO}_{600 \mathrm{~nm}}$ $(-\boldsymbol{t})$ e por UFC/mL ( $-\boldsymbol{-}$ ) e, com glicerol como fonte de carbono analisadas por $\mathrm{DO}_{600 \mathrm{~nm}}(-)$ e por UFC/mL $(-\nabla)$.

Verifica-se pela Figura 4.23 que os resultados obtidos pelas diferentes análises realizadas apresentaram os mesmos perfis, tanto para a lise das células oriundas do cultivo com glicose como do cultivo com glicerol, e que após 6 minutos de lise para o cultivo com glicose e 7 para o cultivo com glicerol formaram-se patamares, indicando que 6 e 7 ciclos, respectivamente, foram suficientes para obtenção do máximo de lise, com exceção da contagem de UFC/mL do cultivo com glicerol, a qual estabilizou-se com 9 minutos.

Observa-se também que a concentração celular inicial do cultivo com glicerol foi maior, praticamente o dobro das amostras do cultivo com glicose, indicando, assim como nas análises de concentração protéica, que o glicerol estaria agindo como conservante da célula durante o congelamento e por isso manteve uma maior quantidade de células íntegras, pois se obteve no final da lise celular a mesma quantidade protéica partindo da mesma massa celular dos dois cultivos. Mesmo começando com uma maior quantidade de células integras, conseguiu-se ao fim do processo maior quantidade de células lisadas do cultivo com glicerol indicadas pela 
$\mathrm{DO}_{600 \mathrm{~nm}}$ e UFC/mL (0,55 e 100, respectivamente) que nas células lisadas do cultivo com glicose (1,52 e 900, respectivamente).

Foi feito um controle da amostra inicial solubilizando as células em $100 \mathrm{mM}$ de $\mathrm{NaOH}$ e o material obtido foi considerado como correspondendo a $100 \%$ de lise. Após a solubilização com $\mathrm{NaOH}$, foi obtida uma $\mathrm{DO}_{600 \mathrm{~nm}}$ de 1,47 para as células do cultivo com glicose como fonte de carbono e de 0,51 para as células do cultivo com glicerol, obtendo a eficiência da lise mecânica de 96,7\% e 92,7\%, respectivamente. Segundo Wong et al. ${ }^{49}, 10$ ciclos foram necessários para uma eficiência de $100 \%$ de ruptura mecânica de E. coli induzida por IPTG.

\subsubsection{Teste de Solubilidade do rfPspA3}

Após a lise celular foi feito o teste de solubilidade do rfPspA3 por centrifugação a $20.817 \mathrm{~g}$ por 2 horas. A Figura 4.24 abaixo mostra o resultado do teste.

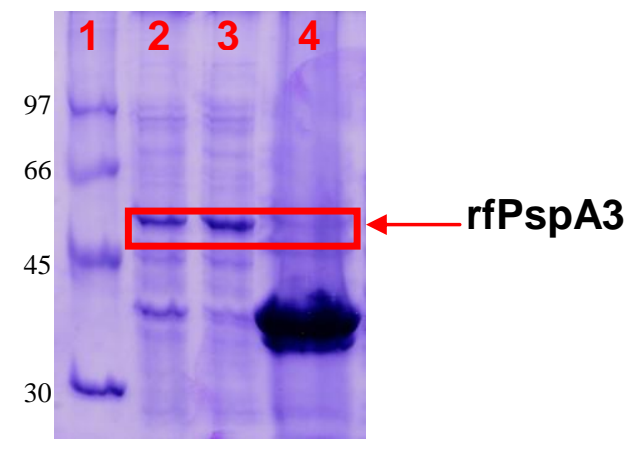

Figura 4.24: Gel de eletroforese do teste de solubilidade da proteína rfPspA3 feito por centrifugação do homogenato bruto da E. coli BL21(DE3) transformada com pET37b+/rfpspA3. 1Padrão de massa molecular $(\mathrm{kDa})$; 2-Homogenato bruto; 3-Sobrenadante do homogenato centrifugado; 4-Precipitado do homogenato centrifugado (5 vezes concentrado).

De acordo com a Figura 4.24, não houve presença significativa do rfPspA3 no precipitado da amostra centrifugada levando-se em consideração que a amostra do precipitado está 5 vezes mais concentrada que o sobrenadante. A partir desta figura, pode-se observar também que, qualitativamente, houve maior concentração do rfPspA3 na amostra após centrifugação, o que pode ser comprovado pela Tabela 4.5, pois uma parte de impurezas foi retirada durante esse processo, como se pode notar no precipitado. Assim, pode-se dizer que ocorreu purificação de 1,26 vezes do rfPspA3 nesta etapa de centrifugação e também que a proteína foi bastante solúvel a pH 8,0. 
Tabela 4.5: Pureza relativa do rfPspA3 antes e após centrifugação.

\begin{tabular}{lc}
\hline Amostra & Pureza Relativa do rfPspA3 (\%) \\
\hline Homogenato bruto & 19,0 \\
Sobrenadante & 23,9 \\
Precipitado & 2,9 \\
\hline
\end{tabular}

Observa-se pela Tabela 4.5 que ocorreu uma pequena perda durante a centrifugação (2,9\% do total de proteínas no precipitado), provavelmente, devido ao arraste do rfPspA3 junto com outras proteínas e debris celulares durante a centrifugação, pois quase toda a proteína permaneceu solúvel após este processo.

\subsubsection{Clarificação do homogenato}

Três condições de clarificação foram testadas a partir de uma mesma amostra: centrifugação, microfiltração tangencial e ultrafiltração tangencial.

Para esses testes, $150 \mathrm{~g}$ de massa úmida celular obtida do cultivo de batelada alimentada com glicose como fonte de carbono foram lisadas em homogeneizador de alta pressão, obtendo-se um volume total de $1910 \mathrm{~mL}$ que foi divido em três partes iguais para as clarificações a serem testadas. Na clarificação por centrifugação, o homogenato centrifugado obtido foi filtrado em membrana de $0,45 \mu \mathrm{m}$ para a retirada de precipitados e outras impurezas, etapa necessária para purificações cromatográficas posteriores.

A Figura 4.25 mostra o resultado dos filtrados obtidos de cada clarificação.

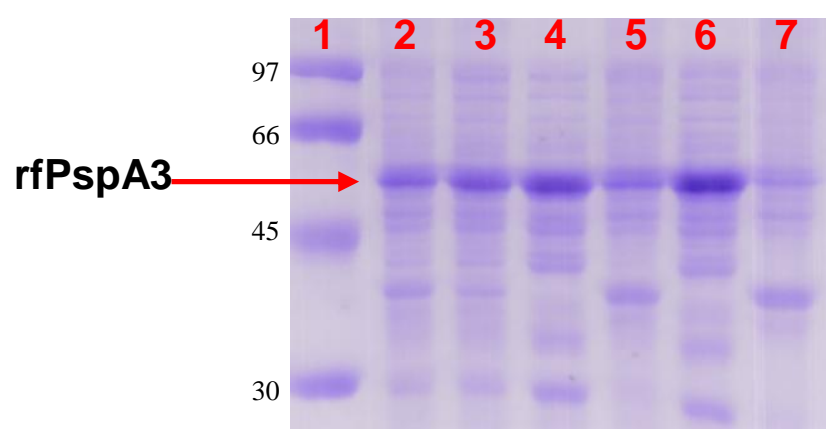

Figura 4.25: Amostras obtidas após diferentes etapas de clarificação (10 $\mu \mathrm{g}$ de proteínas totais). 1Padrão de massa molecular $(\mathrm{kDa})$; 2-Homogenato após lise celular; 3-Clarificado centrifugado e filtrado em membrana de $0,45 \mu \mathrm{m}$ de poro ; 4-Clarificado microfiltrado em fibra oca de 0,1 $\mu \mathrm{m}$ de poro; 5-Fração retida em fibra oca de $0,1 \mu \mathrm{m}$ de poro; 6Clarificado ultrafiltrado em fibra oca de 750 kDa de poro; 7-Fração retida em fibra oca de $750 \mathrm{kDa}$ de poro. 
A Figura 4.26 mostra a foto dos clarificados obtidos.

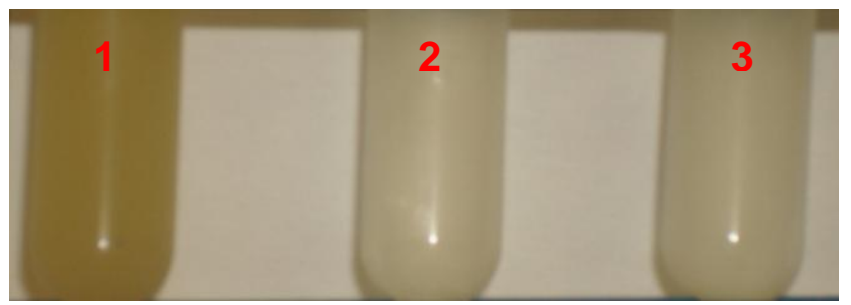

Figura 4.26: Foto dos clarificados em diferentes tratamentos. 1-Clarificado centrifugado e microfiltrado em membrana de poro $0,45 \mu \mathrm{m}$; 2-Clarificado microfiltrado em fibra oca de $0,1 \mu \mathrm{m}$ de poro; 3-Clarificado ultrafiltrado em fibra oca de $750 \mathrm{kDa}$ de poro.

Podemos notar na Figura 4.26 que o clarificado centrifugado possui coloração mais escura indicando que a retirada de impurezas foi menos eficiente. Porém, utilizando a centrifugação não houve variação no volume de amostra após esta etapa. Ao utilizar a fibra-oca com poro de $0,1 \mu \mathrm{m}$ houve uma diluição de 3,3 vezes e de 3,0 vezes para a fibra-oca com poro de $750 \mathrm{kDa}$. Esses clarificados, assim como a porção retida nos filtros do tipo fibra-oca, foram analisados por HPSEC para determinar a porcentagem da área dos picos do cromatograma (Figura 4.27). Os resultados estão apresentados na Tabela 4.6.
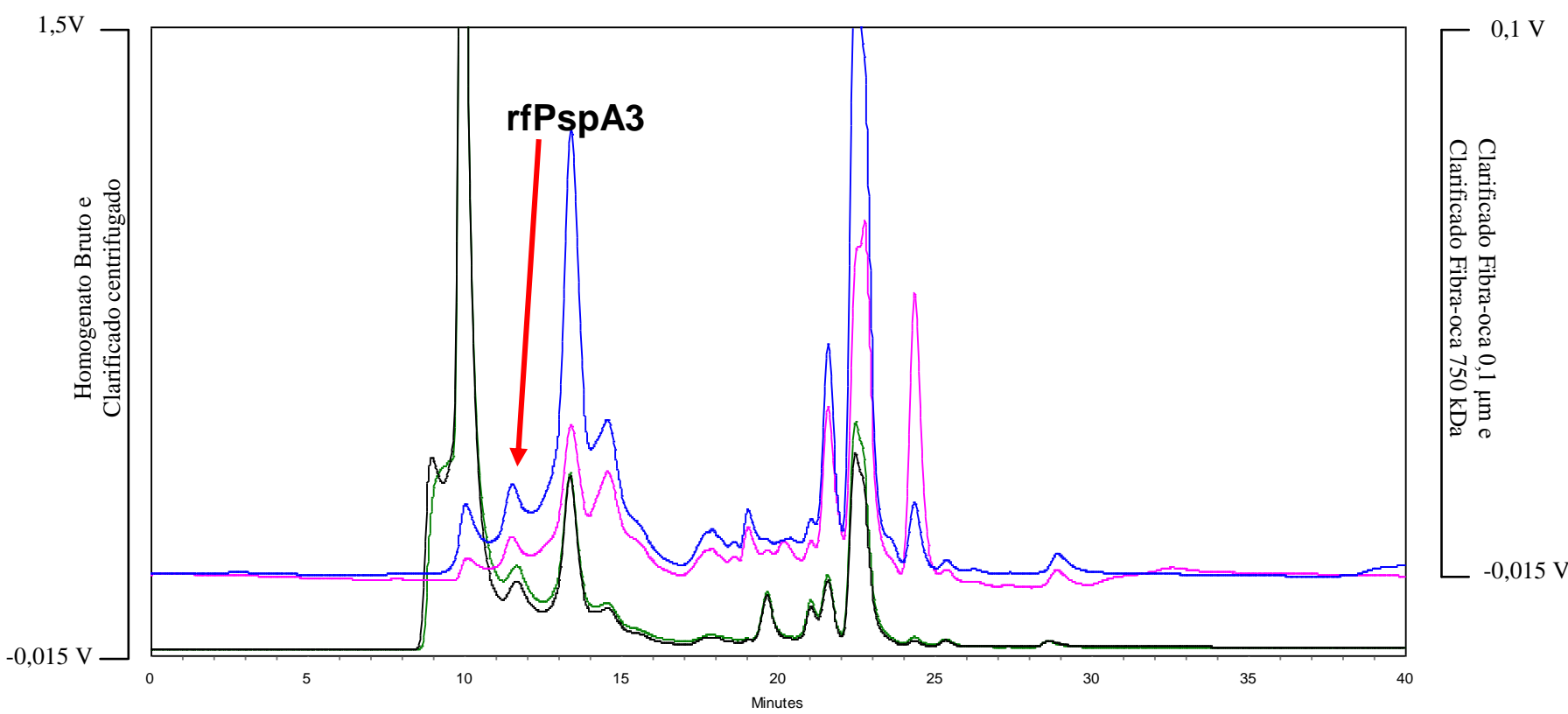

Figura 4.27: Cromatogramas obtidos por HPSEC do homogenato bruto e das 3 clarificações: verde Homogenato bruto, preto - clarificado centrifugado, rosa - clarificado microfiltrado por fibra oca 0,1 $\mu \mathrm{m}$ de poro e azul - clarificado ultrafiltrado por fibra oca $750 \mathrm{kDa}$ de poro. 
Tabela 4.6: Tabela de purificação dos clarificados obtidos por centrifugação, microfiltração e ultrafiltração.

\begin{tabular}{|c|c|c|c|c|c|}
\hline & $\begin{array}{c}\text { Proteínas } \\
\text { Totais }(\mathrm{mg})\end{array}$ & $\begin{array}{c}\text { P. R. }{ }^{*} \\
\text { rfPspA3 (\%) }\end{array}$ & $\begin{array}{c}\text { rfPspA3 } \\
\text { (mg) }\end{array}$ & $\begin{array}{c}\text { Recuperação } \\
\text { da rfPspA3 (\%) }\end{array}$ & $\begin{array}{c}\text { Fator de } \\
\text { Purificação }\end{array}$ \\
\hline C. ${ }^{1}$ Centrifugado & 6444 & 19,9 & 1282 & 100 & 1,0 \\
\hline C. $\mathrm{FO}^{2} 0,1 \mu \mathrm{m}$ & 2076 & 27,1 & 563 & 43,9 & 1,4 \\
\hline Retido FO $0,1 \mu \mathrm{m}$ & 4969 & 14,9 & 740 & 57,7 & - \\
\hline C. FO $750 \mathrm{kDa}$ & 2990 & 26,8 & 801 & 62,5 & 1,3 \\
\hline Retido FO 750 kDa & 3652 & 10,3 & 376 & 29,3 & - \\
\hline
\end{tabular}

*Pureza Relativa por HPSEC

${ }^{1}$ Clarificado ${ }^{2}$ Fibra-oca

Verificou-se, pelos cromatogramas, que a centrifugação não retirou impureza do homogenato, somente diminuiu a concentração de alguns componentes, enquanto que nas filtrações houve retirada significativa de muitas impurezas. Entretanto, neste caso o fator de purificação não compensou a perda obtida. Possivelmente, formou-se uma segunda camada nas membranas, resultante do entupimento dos poros por proteínas, causando assim retenção da rfPspA3. Isso aconteceu em menor intensidade na ultrafiltração, cujos poros são bem menores e mais uniformes (Tabela 4.6). Portanto, levando-se em consideração que a perda de rfPspA3 durante a centrifugação foi muito pequena (Figura 4.24, caneleta 4), e ao se observar que a recuperação obtida das etapas de clarificação em fibra-oca foi baixa (43,9\% e $62,5 \%$, Tabela 4.6) para uma primeira etapa de purificação, a centrifugação foi o método escolhido para a etapa de clarificação.

\subsubsection{Teste de precipitação do rfPspA3 em diferentes pH}

Uma vez que o processo de purificação do rfPspA3 envolve etapas de cromatografia de troca iônica, o comportamento da proteína contida no clarificado centrifugado foi avaliado frente a diferentes $\mathrm{pH}$. Ocorreu precipitação durante 0 ajuste do $\mathrm{pH}$ nas amostras de $\mathrm{pH} 3,0$ à 5,0. Em pH 5,5 a precipitação ocorreu após 3 horas. Nos pH 6,0 à 8,0 não ocorreu precipitação.

$\mathrm{O}$ sobrenadante e o precipitado obtidos em cada $\mathrm{pH}$ foram avaliados por SDS-PAGE. A Figura 4.28 mostra o resultado da eletroforese. 


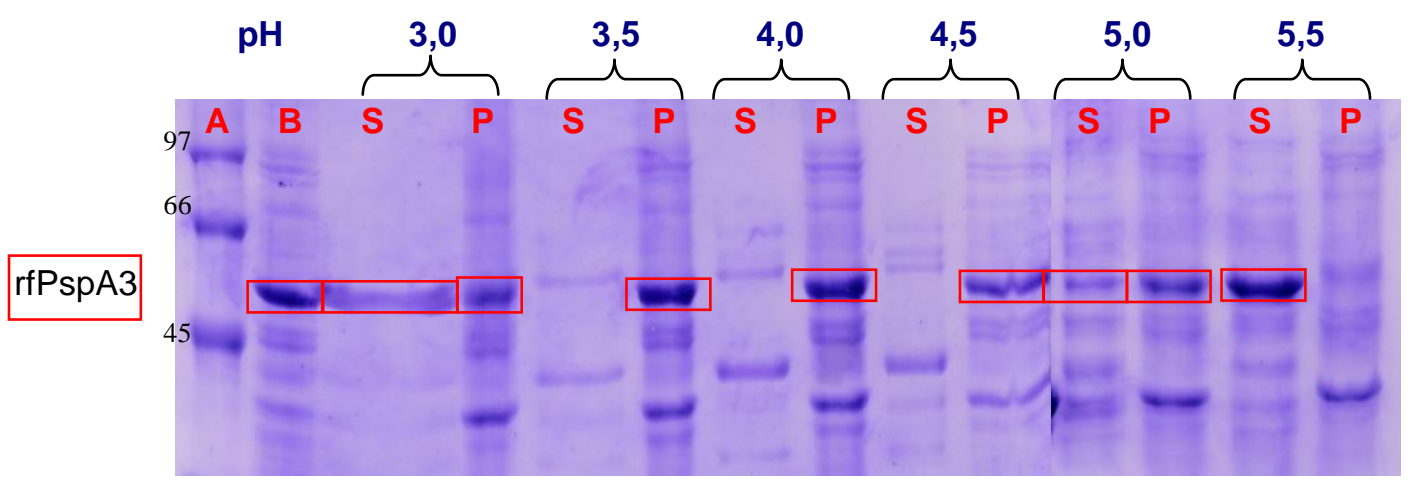

Figura 4.28: Gel de eletroforese do teste de solubilidade do rfPspA3 em diferentes $\mathrm{pH}$. A-Padrão de massa molecular ( $\mathrm{kDa})$; B-Clarificado centrifugado; S-Sobrenadante da amostra no $\mathrm{pH}$ indicado; P-Precipitado da amostra no $\mathrm{pH}$ indicado (10 $\mathrm{\mu g}$ de proteínas totais).

De acordo com a Figura 4.28, percebe-se que o rfPspA3 precipitou em todos os $\mathrm{pH}$, sendo sua presença em maior quantidade nos precipitados obtidos a pH 4,0 e 4,5, que estão próximos ao pl teórico desta proteína $(4,74)$. Em pH 5,5 foi obtida a menor quantidade desta proteína no precipitado. Os dados de densitometria desse gel estão apresentados na tabela 4.7.

Tabela 4.7: Pureza relativa do rfPspA3 no precipitado e sobrenadante das amostras do homogenato a diferentes $\mathrm{pH}$.

\begin{tabular}{lc}
\hline Amostra & $\begin{array}{c}\text { Pureza relativa do } \\
\text { rfPspA3 (\%) }\end{array}$ \\
\hline Clarificado centrifugado & 10,2 \\
Sobrenadante $\mathrm{pH} \mathrm{3,0}$ & 7,8 \\
Precipitado $\mathrm{pH} \mathrm{3,0}$ & 8 \\
Sobrenadante $\mathrm{pH} \mathrm{3,5}$ & 2,2 \\
Precipitado $\mathrm{pH} \mathrm{3,5}$ & 9,8 \\
Sobrenadante $\mathrm{pH} \mathrm{4,0}$ & 4,2 \\
Precipitado $\mathrm{pH} \mathrm{4,0}$ & 9,65 \\
Sobrenadante $\mathrm{pH} \mathrm{4,5}$ & 2,8 \\
Precipitado $\mathrm{pH} \mathrm{4,5}$ & 8,4 \\
Sobrenadante $\mathrm{pH} \mathrm{5,0}$ & 11,9 \\
Precipitado $\mathrm{pH} \mathrm{5,0}$ & 20,9 \\
Sobrenadante $\mathrm{pH} \mathrm{5,5}$ & 36,1 \\
Precipitado $\mathrm{pH} 5,5$ & 6,84 \\
\hline densitometria da eletroforese SDS-PAGE da Figura 4.28.
\end{tabular}

Com relação à quantidade de proteína de entrada, nota-se pela tabela que, com exceção do pH 5,5, a maior parte da proteína total e do rfPspA3 ficou no precipitado. Com esses resultados foi possível montar o perfil recuperação da proteína de interesse e de proteínas totais no sobrenadante em relação ao $\mathrm{pH}$ da amostra como mostra a Figura 4.29. 


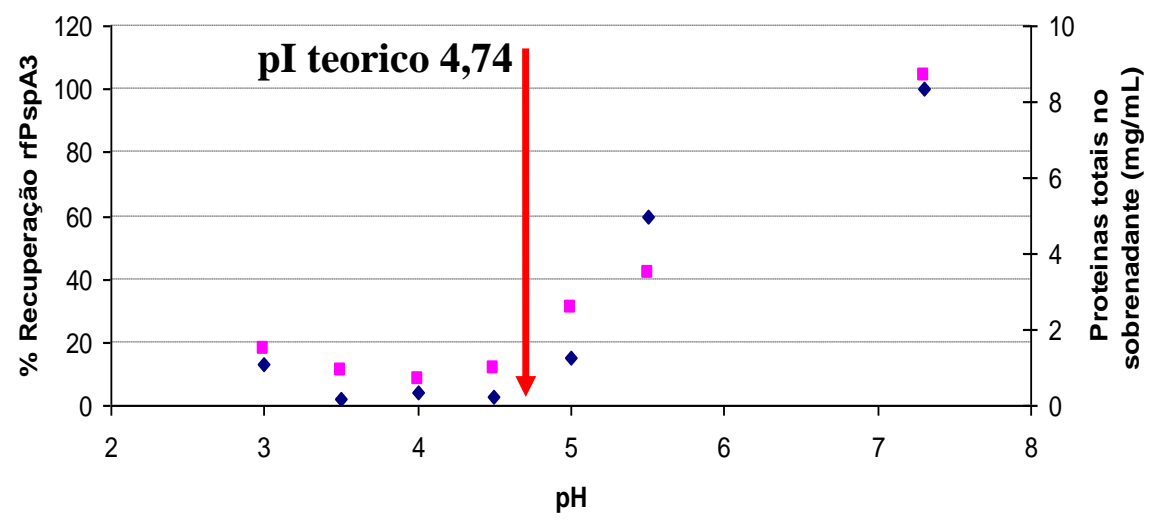

- rfPspA3 - Proteinas totais

Figura 4.29: Perfil da porcentagem de recuperação rfPspA3 e proteínas totais recuperadas no sobrenadante do clarificado centrifugado de E. coli BL21(DE3) submetido a diferentes $\mathrm{pH}$ e a indicação do pl teórico no gráfico.

Verifica-se na Figura 4.29 que na faixa próxima ao pl teórico $(4,74)$ houve maior precipitação da rfPspA3 assim como de proteínas totais. Isso pode ter ocorrido devido ao arraste da ifPspA3 pelas outras proteínas do meio.

\subsubsection{Testes de adsorção em resina Q-sepharose Fast-Flow}

De acordo com as características analisadas do rfPspA3 (item 4.2), nota-se que pelo seu pl teórico em torno de 4,74 e pelas características do clarificado centrifugado utilizado, foi possível sua manipulação em $\mathrm{pH}$ acima de 6,0 sem que houvesse precipitação, deixando-a com carga total negativa o que possibilita o uso de uma etapa cromatográfica de troca aniônica, como a Q-Sepharose, em seu processo de purificação. Para os testes nesta resina, foram utilizados os sobrenadantes de diferentes $\mathrm{pH}$ do teste descrito no item anterior (4.3.5). Para a realização de cromatografia de troca catiônica como primeira etapa seria necessário obter o rfPspA3 com carga positiva ( $\mathrm{pH}$ abaixo do seu pl), ou seja, justamente nos pH em que ocorreram precipitação, por isso seu uso foi descartado.

Para determinar o pH ótimo de adsorção foram feitos testes com $1 \mathrm{~mL}$ de resina Q-Sepharose em batelada previamente equilibrada com tampões na faixa de $\mathrm{pH}$ de 4,5 a 8,0 variando 0,5 valor de $\mathrm{pH}$. Após a adsorção do clarificado à resina, as amostras do sobrenadante (fração não-adsorvida) foram analisadas por SDS-PAGE (Figura 4.30). 


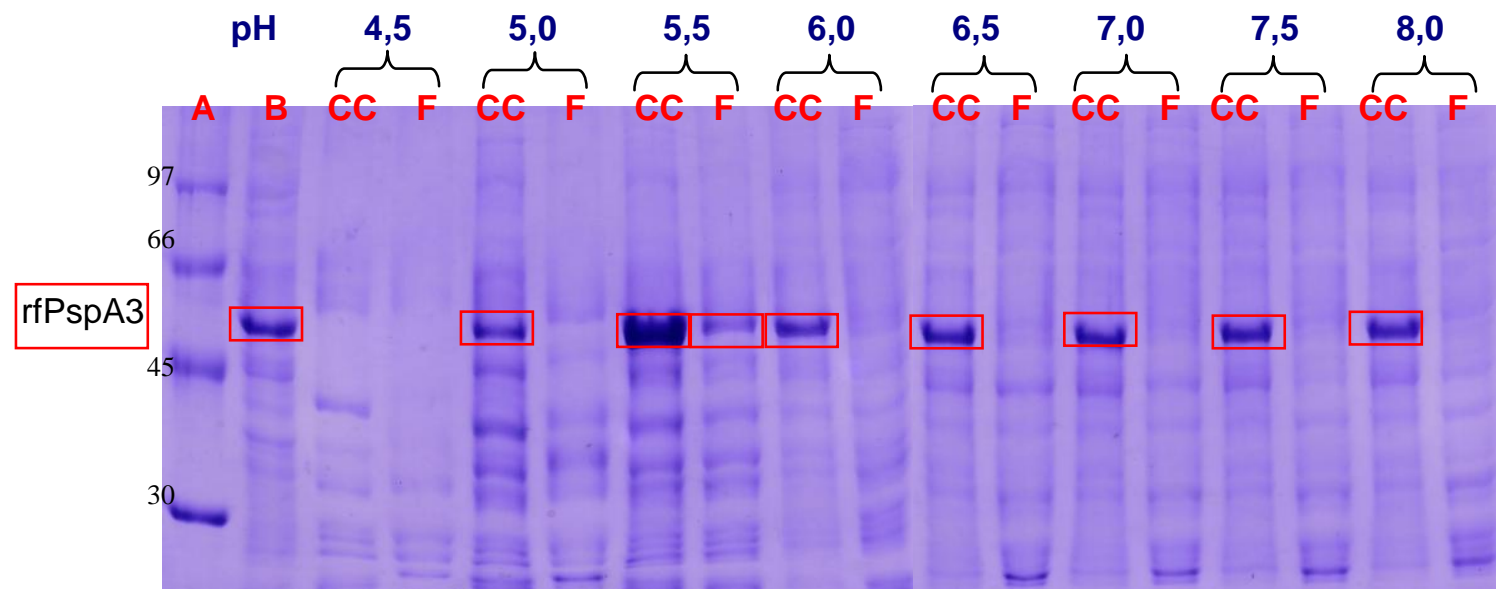

Figura 4.30: Gel de eletroforese da adsorção do clarificado centrifugado em resina Q-sepharose FF em diferentes $\mathrm{pH}$. A-Padrão de massa molecular $(\mathrm{kDa})$; B-Clarificado centrifugado; CCClarificado centrifugado no pH indicado; F-Fração não-adsorvida em resina Qsepharose no $\mathrm{pH}$ indicado (10 $\mu \mathrm{g}$ de proteínas totais).

Observa-se pela figura 4.30 que a adsorção quase completa do rfPspA3 em Q-Sepharose ocorreu a partir do pH 6,0. Observa-se também nas frações nãoadsorvidas a $\mathrm{pH}$ 6,0-8,0 a presença de uma pequena quantidade do rfPspA3 ou de uma proteína de mesma massa molecular aparente que ela. Assim, foi feita a densitometria desse gel de eletroforese para verificar a quantidade do $\operatorname{rfPspA} 3$ presente nas frações não-adsorvidas. A Tabela 4.8 apresenta estes resultados. 
Tabela 4.8: Pureza relativa do rfPspA3, sua concentração e recuperação nas frações não-adsorvidas em resina de troca-aniônica $\mathrm{Q}$-sepharose em diferentes $\mathrm{pH}$.

\begin{tabular}{lcccc}
\hline Amostra & $\begin{array}{c}\text { PT* } \\
(\mathbf{m g} / \mathbf{m L})\end{array}$ & $\begin{array}{c}\text { Pureza relativa } \\
\text { do rfPspA3 }(\%)\end{array}$ & $\begin{array}{c}\text { rfPspA3 } \\
(\mathbf{m g} / \mathbf{m L})\end{array}$ & $\begin{array}{c}\text { Recuperação } \\
\text { do rfPspA3 } \\
(\%)\end{array}$ \\
\hline Clarificado $1^{1}$ & 8,7 & 21,2 & 1,84 & 100 \\
pH 4,5 CC** & 1 & 3,1 & 0,03 & 2 \\
pH 4,5 F*** & 0,39 & 0 & 0,0 & 0 \\
pH 5,0 CC & 2,6 & 11,7 & 0,30 & 16 \\
pH 5,0 F & 0,56 & 4,35 & 0,02 & 1 \\
pH 5,5 CC & 3,5 & 28 & 0,98 & 53 \\
pH 5,5 F & 1,26 & 12,2 & 0,15 & 8 \\
pH 6,0 CC & 8,7 & 25,7 & 2,24 & 121 \\
pH 6,0 F & 2,42 & 3,09 & 0,07 & 4 \\
\hline Clarificado 2 & 8,7 & 19 & 1,65 & 100 \\
pH 6,5 CC & 8,7 & 24,6 & 2,14 & 129 \\
pH 6,5 F & 2,78 & 2,97 & 0,08 & 5 \\
pH 7,0 CC & 8,7 & 19,2 & 1,67 & 101 \\
pH 7,0 F & 2,65 & 2,22 & 0,06 & 4 \\
pH 7,5 CC & 8,7 & 19,2 & 1,67 & 101 \\
pH 7,5 F & 2,32 & 2,6 & 0,06 & 4 \\
pH 8,0 CC & 8,7 & 21 & 1,83 & 111 \\
pH 8,0 F & 1,88 & 2,98 & 0,06 & 3 \\
\hline
\end{tabular}

De acordo com a Tabela 4.8, a pH>6,0 houve pouco rfPspA3 na fração que não foi adsorvida ( 3\%), como já se tinha notado pelo gel de eletroforese (Figura 4.30). Porém, a distância percorrida pela proteína em relação à altura total do gel (Relative Front - RF) diferiu um pouco do RF da banda de rfPspA3 presente no clarificado centrifugado. Assim, foi feito um Western Blotting para avaliar se esta banda era ou não do rfPspA3. A Figura 4.31 mostra os resultados obtidos desta análise. 


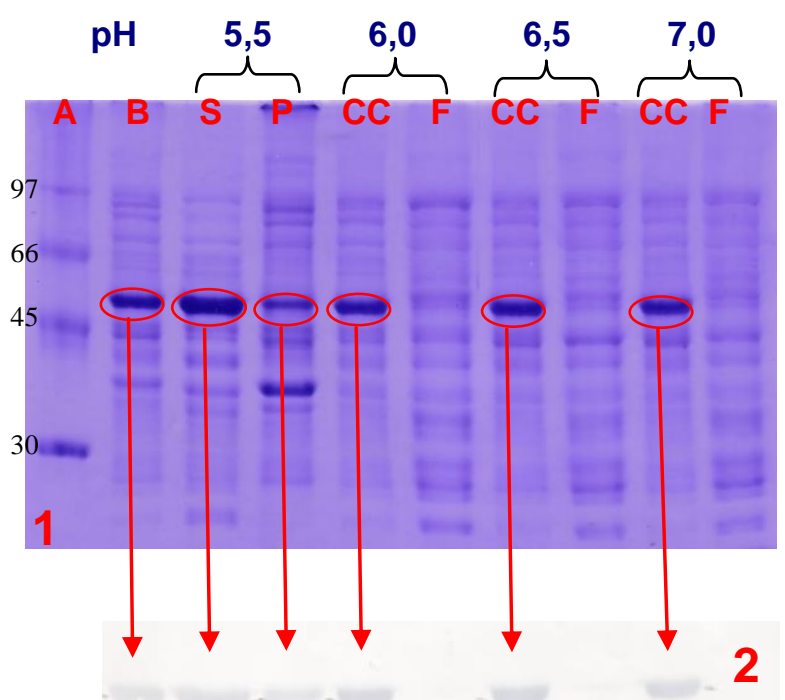

Figura 4.31: 1-Gel de eletroforese de testes de adsorção do clarificado centrifugado em resina QSepharose em diferentes pH. A-Padrão de massa molecular $(\mathrm{kDa})$; B-Clarificado centrifugado; S-Sobrenadante do clarificado no $\mathrm{pH}$ indicado; P-Precipitado do clarificado no pH indicado; CC- Clarificado centrifugado no $\mathrm{pH}$ indicado $(10 \mu \mathrm{g}$ de proteínas totais); F-Fração não-adsorvida do clarificado em resina Q-Sepharose no pH indicado (10 $\mathrm{\mu g}$ de proteínas totais). 2-Western Blotting obtido a partir do gel de eletroforese 1.

De acordo com a Figura 4.31, percebe-se que em $\mathrm{pH}>6,0$ não houve perda de rfPspA3 na fração não-adsorvida, como é mostrado pelo Western Blotting. $\mathrm{Na}$ fração não-adsorvida em pH 6,0, há um indício de que a concentração de impurezas foi um pouco maior que nos outros $\mathrm{pH}$. No teste em $\mathrm{pH} 5,5$ do clarificado centrifugado, verifica-se que houve grande perda da proteína também no precipitado, indicando a inviabilidade desse $\mathrm{pH}$ nessa etapa de purificação devido à baixa recuperação de $\mathrm{rfPspA3}$.

Determinado o pH 6,0 para adsorção em Q-Sepharose, foi então avaliado o efeito da condutividade com o objetivo de definir as condições de maior retirada de impurezas na fração não-adsorvida, porém sem perdas de rfPspA3. Para isso diferentes concentrações de $\mathrm{NaCl}(0$ à $500 \mathrm{mM})$ foram adicionadas ao tampão de equilíbrio (acetato pH 6,0) e ao clarificado (amostra). A Tabela 4.9 mostra o valor da condutividade na qual a amostra foi ajustada nas diferentes concentrações do sal e a Figura 4.32 apresenta o gel de eletroforese das frações obtidas. 
Tabela 4.9: Concentração de $\mathrm{NaCl}$ na solução tampão acetato $25 \mathrm{mM}$ e sua respectiva condutividade.

\begin{tabular}{lcc}
\hline \multicolumn{1}{c}{ Amostra } & $\mathbf{N a C l}(\mathbf{m M})$ & Condutividade (mS/cm) \\
\hline Homogenato centrifugado & 0,0 & 2,6 \\
Tampão Acetato pH 6,0 & 0,0 & 1,7 \\
Tampão Acetato pH 6,0 & 10,0 & 2,6 \\
Tampão Acetato pH 6,0 & 20,0 & 3,5 \\
Tampão Acetato pH 6,0 & 30,0 & 4,3 \\
Tampão Acetato pH 6,0 & 40,0 & 5,2 \\
Tampão Acetato pH 6,0 & 50,0 & 6,0 \\
Tampão Acetato pH 6,0 & 75,0 & 8,3 \\
Tampão Acetato pH 6,0 & 100 & 10,2 \\
Tampão Acetato pH 6,0 & 150 & 14,5 \\
Tampão Acetato pH 6,0 & 200 & 18,4 \\
Tampão Acetato pH 6,0 & 300 & 25,7 \\
Tampão Acetato pH 6,0 & 400 & 32,7 \\
Tampão Acetato pH 6,0 & 500 & 40,0 \\
\hline
\end{tabular}
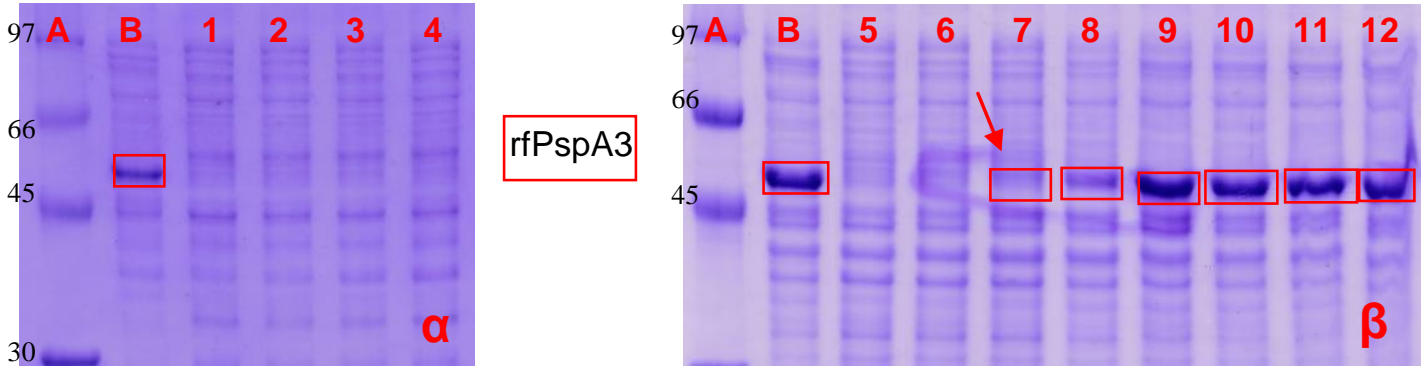

Figura 4.32: $\alpha$ e $\beta$-Géis de eletroforese do teste de adsorção do clarificado centrifugado em resina Qsepharose em diferentes concentrações de $\mathrm{NaCl}$. A-Padrão de massa molecular ( $\mathrm{kDa}$ ); B-Clarificado centrifugado (10 $\mu \mathrm{g}$ de proteínas totais); 1-12-Frações não-adsorvidas (em todas $10 \mu \mathrm{g}$ de proteínas totais) com: $1-10 \mathrm{mM}$ de NaCl; $2-20 \mathrm{mM}$ de $\mathrm{NaCl} ; 3-30 \mathrm{mM}$ de $\mathrm{NaCl}$; $4-40 \mathrm{mM}$ de $\mathrm{NaCl} ; 5-50 \mathrm{mM}$ de $\mathrm{NaCl} ; 6-75 \mathrm{mM}$ de $\mathrm{NaCl} ; 7-100 \mathrm{mM}$ de $\mathrm{NaCl}$; 8$150 \mathrm{mM}$ de NaCl; $9-200 \mathrm{mM}$ de $\mathrm{NaCl} ; 10-300 \mathrm{mM}$ de $\mathrm{NaCl} ; 11-400 \mathrm{mM}$ de $\mathrm{NaCl}$ e $12-$ $500 \mathrm{mM}$ de NaCl.

A Figura 4.33 apresenta os valores de quantidade relativa de rfPspA3 medida por densitometria dos géis de eletroforese mostrados na Figura 4.32. 


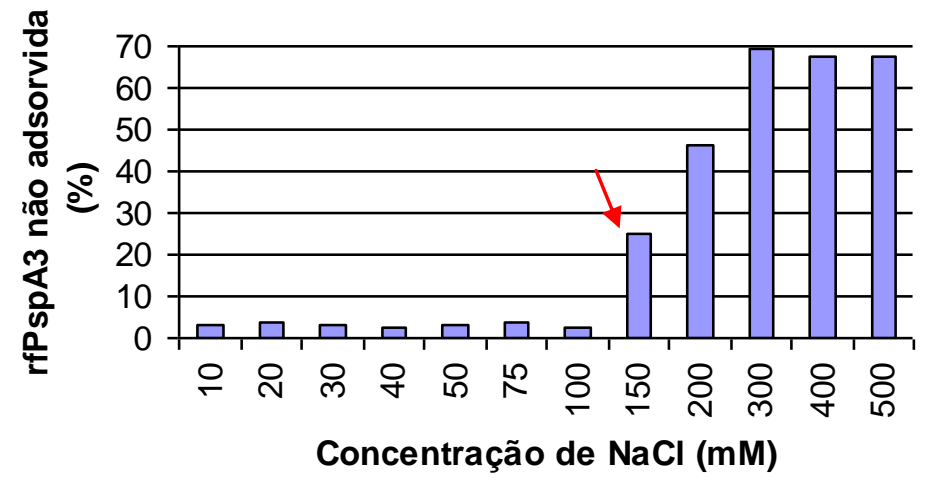

Figura 4.33: Porcentagem relativa de rfPspA3 medida por densitometria das bandas nas frações nãoadsorvidas em resina Q-Sepharose FF em diferentes concentrações de $\mathrm{NaCl}$.

De acordo com os resultados obtidos, com concentração de $150 \mathrm{mM}$ de $\mathrm{NaCl}$ (indicada por uma seta nas Figuras $4.32 \beta$ e 4.33) uma banda com mesma massa aparente que rfPspA3 começou a se concentrar indicando que nesta condutividade há carga iônica suficiente para deslocar a proteína, havendo assim menor adsorção pela resina e consequentemente ocasionando sua perda em torno de $25 \%$. Em concentrações de $\mathrm{NaCl}$ abaixo desta observou-se a presença, em todas as amostras, de aproximadamente $3 \%$ de rfPspA3, que pode ser considerada uma medida basal, uma vez que este mesmo valor apareceu na Tabela 4.8. A partir de $300 \mathrm{mM}$ de $\mathrm{NaCl}$, podemos observar que houve total deslocamento da proteína, ficando perto de $70 \%$ na fração não-adsorvida. Com esses resultados, determinouse a condição de entrada da amostra na cromatografia em Q-Sepharose a pH 6,0 com condutividade equivalente a $50 \mathrm{mM}$ de $\mathrm{NaCl}$, na tentativa de obter-se maior quantidade de impurezas na fração não-adsorvida. Mesmo sabendo que a eluição das proteínas em colunas cromatográficas ocorrem em uma cinética diferente da adsorção, pode-se inferir dos dados apresentados que a concentração de $\mathrm{NaCl}$ a ser utilizada na eluição deveria partir de $250 \mathrm{mM}$.

\subsubsection{Testes em Colunas Cromatográficas}

\subsubsection{Q-Sepharose Fast-Flow}

Após determinada a condição de adsorção da rfPspA3 à Q-Sepharose, testes em colunas empacotadas foram realizados para estabelecer as condições de eluição levando-se em consideração os testes realizados em tubos. Foi utilizado 
volume de coluna de $10 \mathrm{~mL}$. Foram aplicados à resina previamente equilibrada $50 \mathrm{~mL}$ do clarificado centrifugado. A coluna foi previamente equilibrada com o tampão acetato $25 \mathrm{mM} \mathrm{pH} \mathrm{6,0} \mathrm{com} 50 \mathrm{mM}$ de $\mathrm{NaCl}$. Para as lavagens e eluição foram empregados 5 volumes de coluna do tampão acetato $25 \mathrm{mM} \mathrm{pH} \mathrm{6,0} \mathrm{com}$ diferentes concentrações de $\mathrm{NaCl}$, como indicado na Figura 4.34.

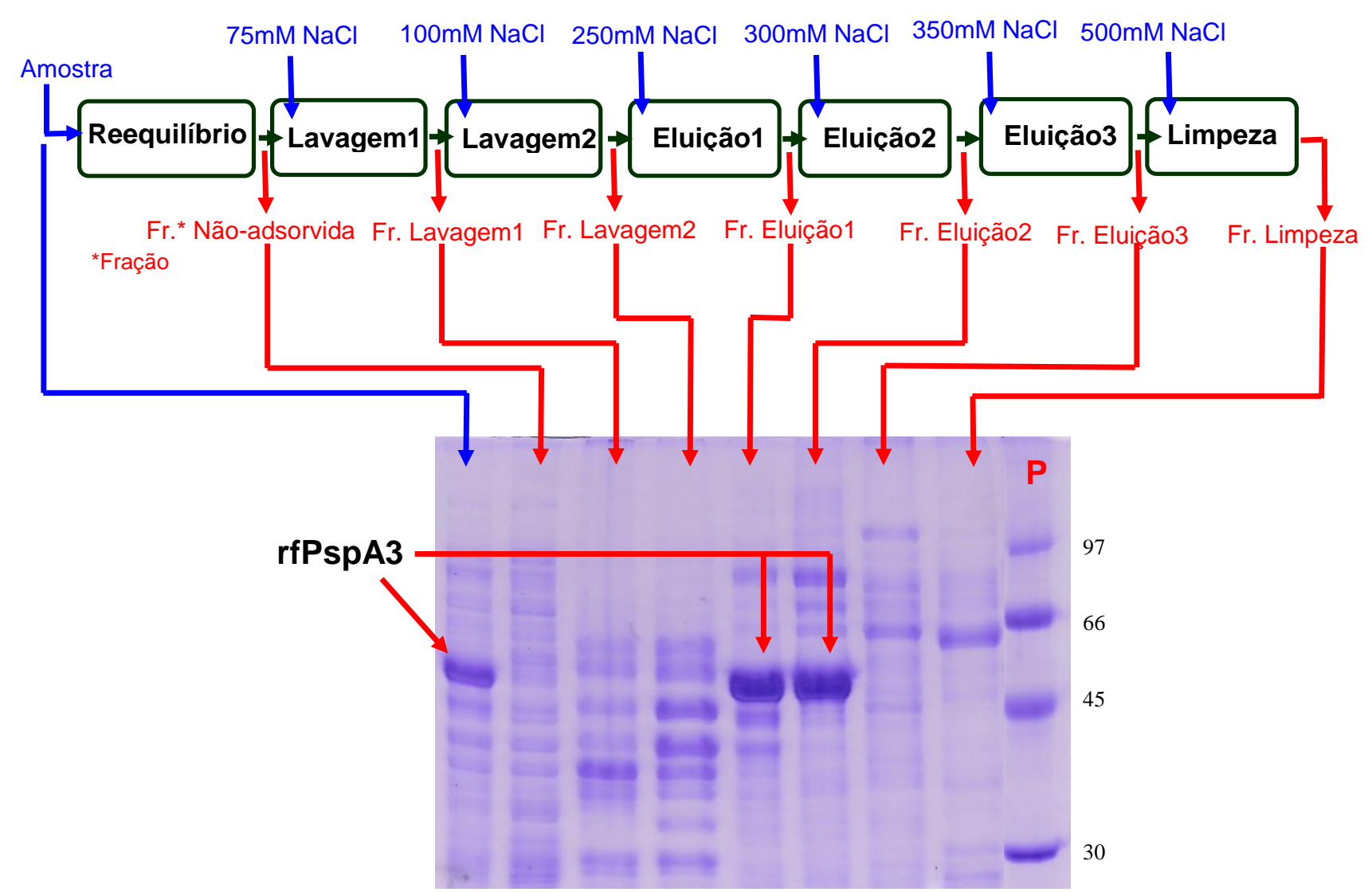

Figura 4.34: Fluxograma do primeiro teste cromatográfico em coluna empacotada com resina de troca iônica Q-sepharose e gel de eletroforese SDS-PAGE de cada fração obtida conforme indicado pelas setas e P-Padrão de massa molecular $(\mathrm{kDa})$. Setas azuis: entrada dos tampões e setas vermelhas: saída das frações, as quais foram analisadas por eletroforese SDS-PAGE. Todas as frações com $10 \mu \mathrm{g}$ de proteínas totais.

De acordo com a Figura 4.34, verifica-se que acima de $75 \mathrm{mM}$ de $\mathrm{NaCl}$ houve perdas de rfPspA3 porém, nessas concentrações houve maior remoção de impurezas como mostra as caneletas 3 e 4 da eletroforese acima. Com relação à eluição, na fração com $250 \mathrm{mM}$ de $\mathrm{NaCl}$ consegue-se recuperar uma boa parte da proteína de interesse, porém não toda, sendo o restante eluído na fração de 300 $\mathrm{mM}$, não havendo presença na fração de $350 \mathrm{mM}$ nem na fração de limpeza com $500 \mathrm{mM}$ de NaCl. 
Um segundo teste cromatográfico foi realizado com as mesmas condições de adsorção (tampão acetato $25 \mathrm{mM} \mathrm{pH} \mathrm{6,0+50} \mathrm{mM} \mathrm{de} \mathrm{NaCl}$ ) e diferentes condições de lavagem e eluição. A etapa de Lavagem com $75 \mathrm{mM}$ de $\mathrm{NaCl}$ foi retirada e outra com $125 \mathrm{mM}$ foi introduzida a fim de aumentar a remoção de impurezas. A eluição a $250 \mathrm{mM}$ de $\mathrm{NaCl}$ foi substituída pela eluição a $275 \mathrm{mM}$ para saber se há possibilidade de recuperar toda a rfPspA3 nessa concentração, deixando ainda impurezas ligadas à resina. Os resultados do teste estão apresentados na Figura 4.35 abaixo:

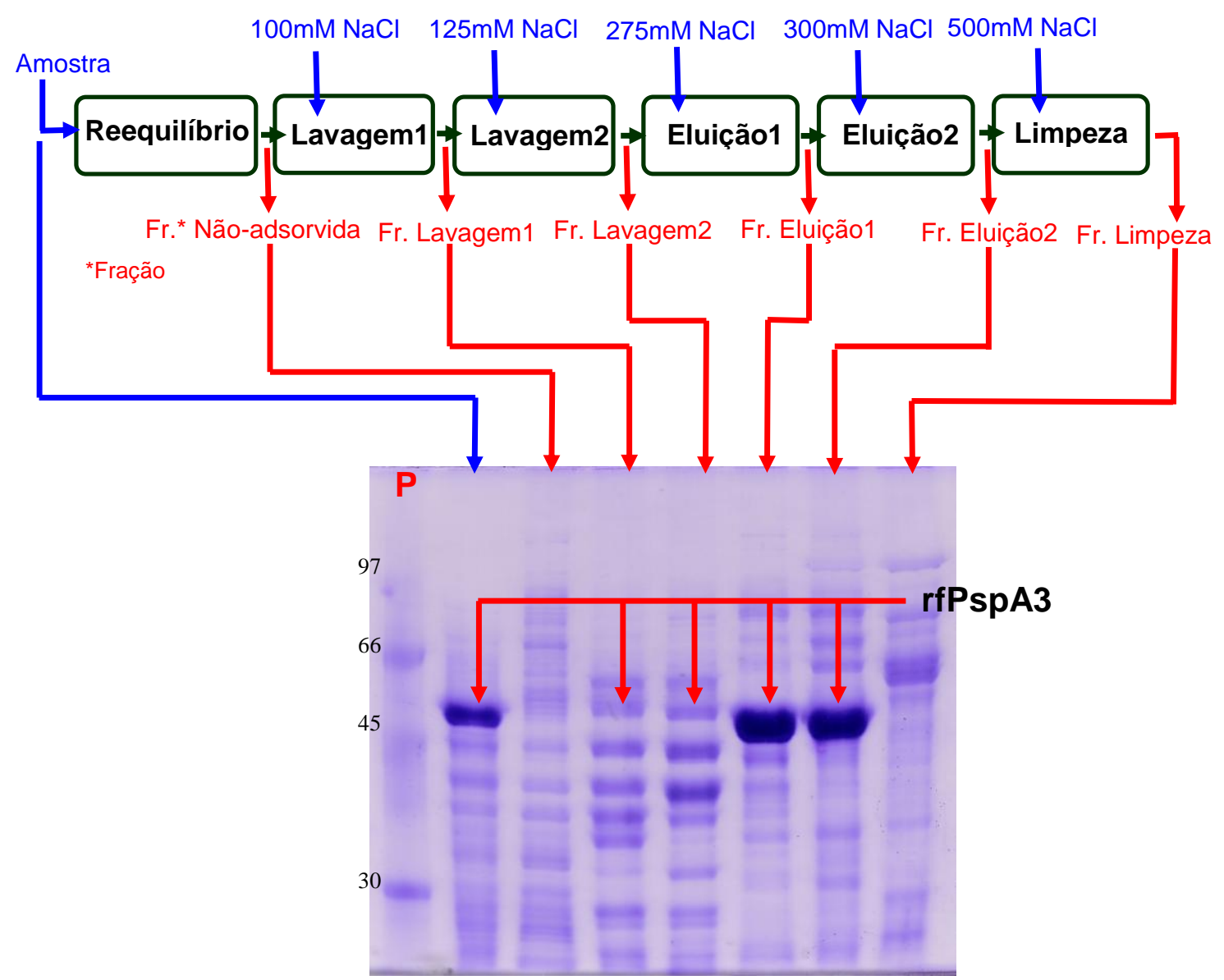

Figura 4.35: Fluxograma do segundo teste cromatográfico em coluna empacotada com resina de troca iônica Q-sepharose e gel de eletroforese SDS-PAGE de cada fração obtida conforme indicado pelas setas e P-Padrão de massa molecular ( $k D a)$. Setas azuis: entrada dos tampões e setas vermelhas: saída das frações, as quais foram analisadas por eletroforese SDS-PAGE. Todas as frações com $10 \mu \mathrm{g}$ de proteínas totais.

A partir dos resultados apresentados na Figura 4.35, nota-se que utilizando Lavagem com $125 \mathrm{mM}$ de $\mathrm{NaCl}$, apesar de haver maior remoção de impurezas, houve também $9 \%$ de perda de rfPspA3 aplicada à resina. Observa-se também que 
$275 \mathrm{mM}$ de $\mathrm{NaCl}$ não foi suficiente para recuperar toda a proteína, sendo o restante eluído na fração de $300 \mathrm{mM}$.

Mesmo com a perda de rfPspA3 na lavagem com $125 \mathrm{mM} \mathrm{NaCl}$, no terceiro teste cromatográfico, esta lavagem foi mantida a fim de se avaliar se um ganho em pureza na fração de eluição compensaria a perda na lavagem. Os resultados obtidos estão apresentados na Figura 4.36 e na Tabela 4.10.

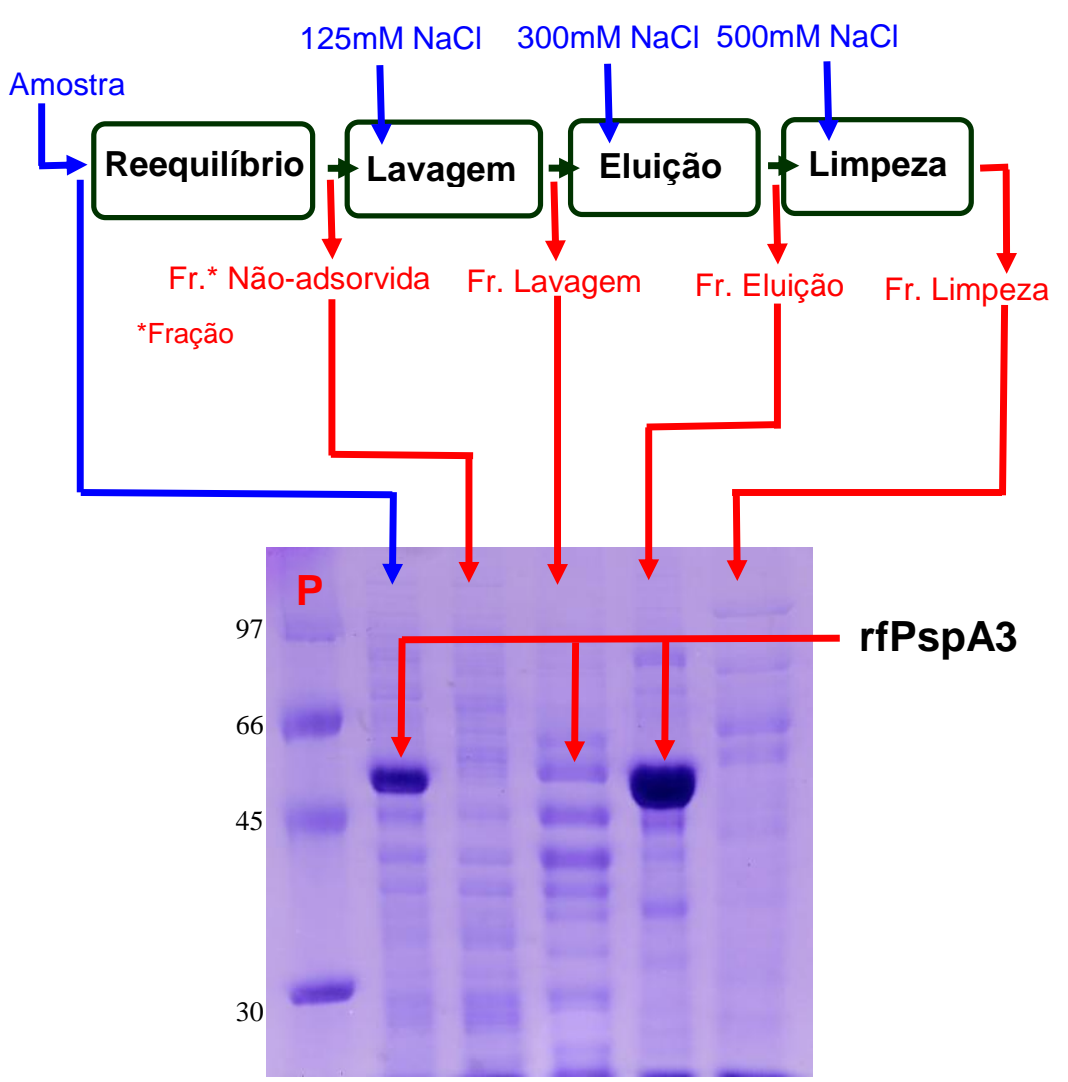

Figura 4.36: Fluxograma do terceiro teste cromatográfico em coluna empacotada com resina de troca iônica Q-sepharose e gel de eletroforese SDS-PAGE de cada fração obtida conforme indicado pelas setas e P-Padrão de massa molecular $(\mathrm{kDa})$. Setas azuis: entrada dos tampões e amostra e setas vermelhas: saída das frações, as quais foram analisadas por eletroforese SDS-PAGE. Todas as frações com $10 \mu \mathrm{g}$ de proteínas totais.

A partir da eletroforese mostrada na Figura 4.36, foi feita uma densitometria, cujo resultado encontra-se na Tabela 4.10 com os valores de porcentagem relativa de rfPspA3 em cada fração. 
Tabela 4.10: Tabela de purificação de rfPspA3 do terceiro teste de dessorção com a resina Qsepharose.

\begin{tabular}{|c|c|c|c|c|}
\hline & $\begin{array}{l}\mathrm{PT}^{*} \\
(\mathrm{mg})\end{array}$ & $\begin{array}{l}\text { Quantidade Relativa } \\
\text { de rfPspA3 }(\%)^{* *}\end{array}$ & $\begin{array}{c}\text { rfPspA3 } \\
\text { (mg) }\end{array}$ & $\begin{array}{c}\text { Rendimento } \\
(\%)\end{array}$ \\
\hline Clarificado centrifugado & 265,5 & 31,08 & 82,5 & 100 \\
\hline Fração não-adsorvida & 118,3 & 0 & 0,0 & 0 \\
\hline Lavagem $125 \mathrm{mM} \mathrm{NaCl}$ & 28,4 & 10,52 & 3,0 & 3,62 \\
\hline Eluição 300 mM NaCl & 77,1 & 44,81 & 34,6 & 41,89 \\
\hline Limpeza $500 \mathrm{mM} \mathrm{NaCl}$ & 7,7 & 0 & 0,0 & 0 \\
\hline
\end{tabular}

*Proteínas Totais; ${ }^{* *}$ por densitometria

Pelos resultados apresentados na Tabela 4.10, observa-se que houve perda de $3,62 \%$ de rfPspA3 na lavagem mantida a $125 \mathrm{mM}$ de $\mathrm{NaCl}$. O rendimento do processo foi baixo de acordo com a densitometria, 41,9\%, porém, o valor da quantidade relativa de rfPspA3 pode estar subestimado na fração de eluição devido à grande quantidade de proteína aplicada ao gel de eletroforese, o que resultou em uma intensidade de coloração da banda de rfPspA3 que ultrapassou a capacidade de detecção do densitômetro. Corroborando esta hipótese, pode-se observar na Figura 4.36 que todo o ifPspA3 foi recuperado na fração de eluição (300 mM de $\mathrm{NaCl}$ ), não sendo encontrado na fração de limpeza, não havendo assim razão aparente para um rendimento tão baixo nesta cromatografia .

\subsubsection{IMAC-Sepharose Fast-Flow carregada com $\mathrm{Ni}^{+2}$}

Para definir as condições para realização da cromatografia de afinidade por metal empregando a IMAC-Sepharose carregada com $\mathrm{Ni}^{+2}$, foram feitos três testes utilizando como material de partida um "pool" das frações de eluição da QSepharose. A escolha da IMAC foi devida à presença da cauda de histidina presente no fragmento recombinante da PspA3 clonada na E. coli, ou seja, o fragmento clonado possui no início da sua sequência a presença de 6 histidinas. Esse aminoácido possui afinidade pelo $\mathrm{Ni}^{+2} \circ$ que possibilita 0 uso da resina IMACSepharose carregada com esse metal em uma etapa cromatográfica de afinidade. Foi utilizado um volume de $20 \mathrm{~mL}$ de resina carregada com $\mathrm{Ni}^{+2}$, previamente equilibrada com o tampão Tris $25 \mathrm{mM} \mathrm{pH} 8,0$ contendo $5 \mathrm{mM}$ de imidazol e $300 \mathrm{mM}$ de $\mathrm{NaCl}$ (usado para evitar ligações inespecíficas). As etapas cromatográficas foram feitas com 5 volumes de coluna. 
Para o primeiro teste, utilizou-se como amostra um pool das frações de 250 e $300 \mathrm{mM}$ de $\mathrm{NaCl}$ do primeiro teste da Q-sepharose. Houve um problema durante a etapa de reequilíbrio da coluna, foi adicionado em torno de $15 \mathrm{~mL}$ de um tampão com concentração de imidazol de $250 \mathrm{mM}$. Foi obtido um pico a $280 \mathrm{~nm}$ com esse tampão, esta fração foi recolhida separadamente e analisada junto com as outras etapas do processo, essa fração foi denominada "fração erro". A Figura 4.37 mostra as etapas do processo e a análise de cada uma através do gel de eletroforese SDS-

PAGE:

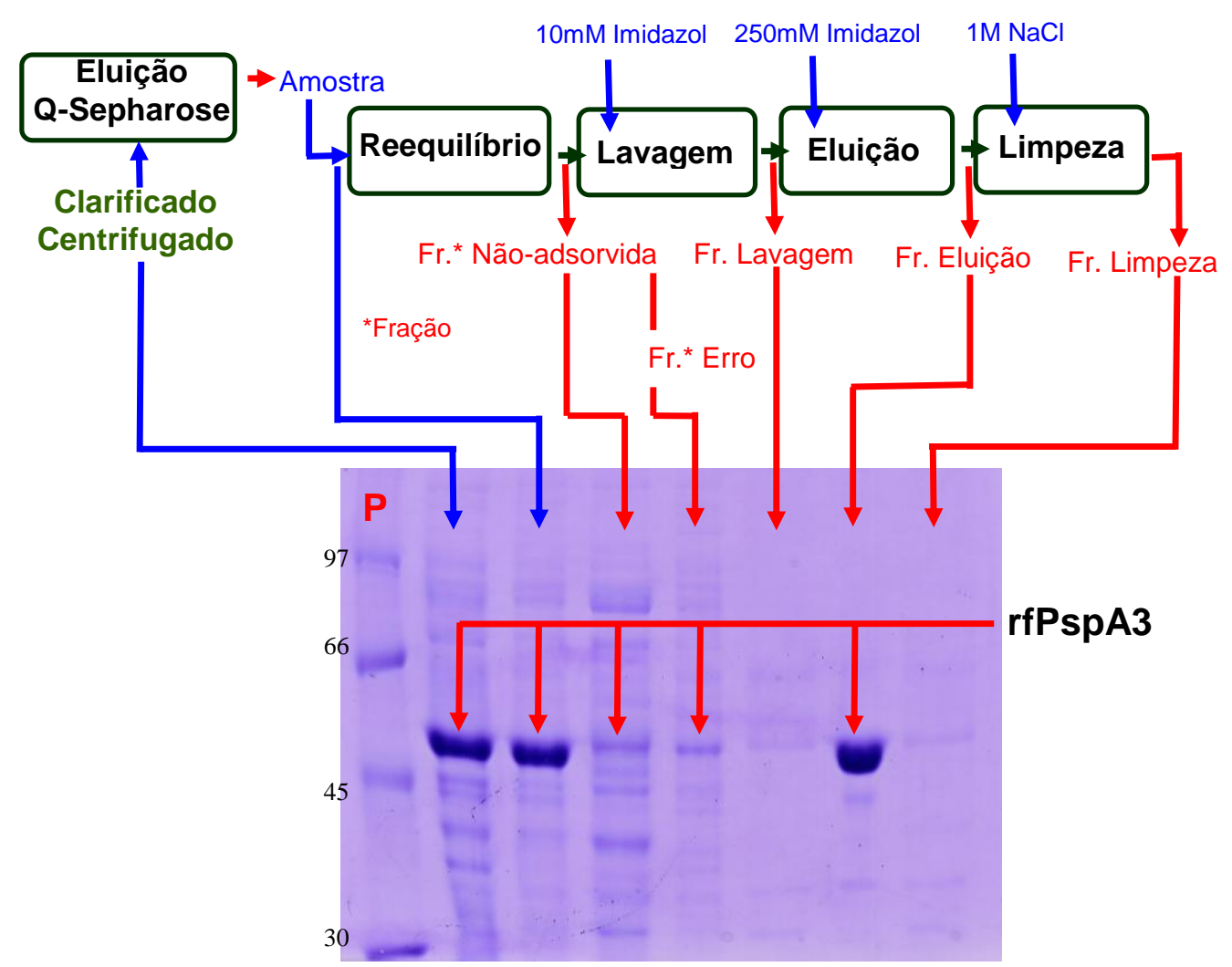

Figura 4.37: Fluxograma do primeiro teste de eluição em coluna empacotada com resina de afinidade IMAC-sepharose Fast-Flow carregada com $\mathrm{Ni}^{+2}$ e abaixo o gel de eletroforese SDSPAGE de cada etapa do processo indicada pela seta e P-Padrão de massa molecular $(\mathrm{kDa})$. Setas azuis: entrada dos tampões e amostras anteriores a esta etapa de cromatografia que também foram analisadas e setas vermelhas: saída das frações, as quais foram analisadas por eletroforese SDS-PAGE. Fração de eluição com $2 \mu \mathrm{g}$ de proteínas totais e demais frações com $10 \mu \mathrm{g}$ de proteínas totais.

Observa-se pela Figura 4.37 que durante a lavagem e também na fração erro houve perda de rfPspA3, porém houve também retirada de impurezas nestas frações. Nota-se também que $250 \mathrm{mM}$ de imidazol foi suficiente para recuperar toda a proteína, uma vez que sua presença não foi detectada na fração de limpeza com $1,0 \mathrm{M}$ de $\mathrm{NaCl}$. Calculou-se que a concentração de imidazol da fração erro foi de 
aproximadamente de $15 \mathrm{mM}$ devido a diluição, e como nesta concentração houve remoção importante de impurezas, um segundo processo foi testado utilizando esta concentração de imidazol na fração de lavagem e também a de $20 \mathrm{mM}$. O material de partida para este teste foi o pool das eluições com 275 e 300 mM de $\mathrm{NaCl}$ do segundo teste em Q-sepharose. O processo e a análise dos resultados em eletroforese SDS-PAGE estão apresentados na Figura 4.38.

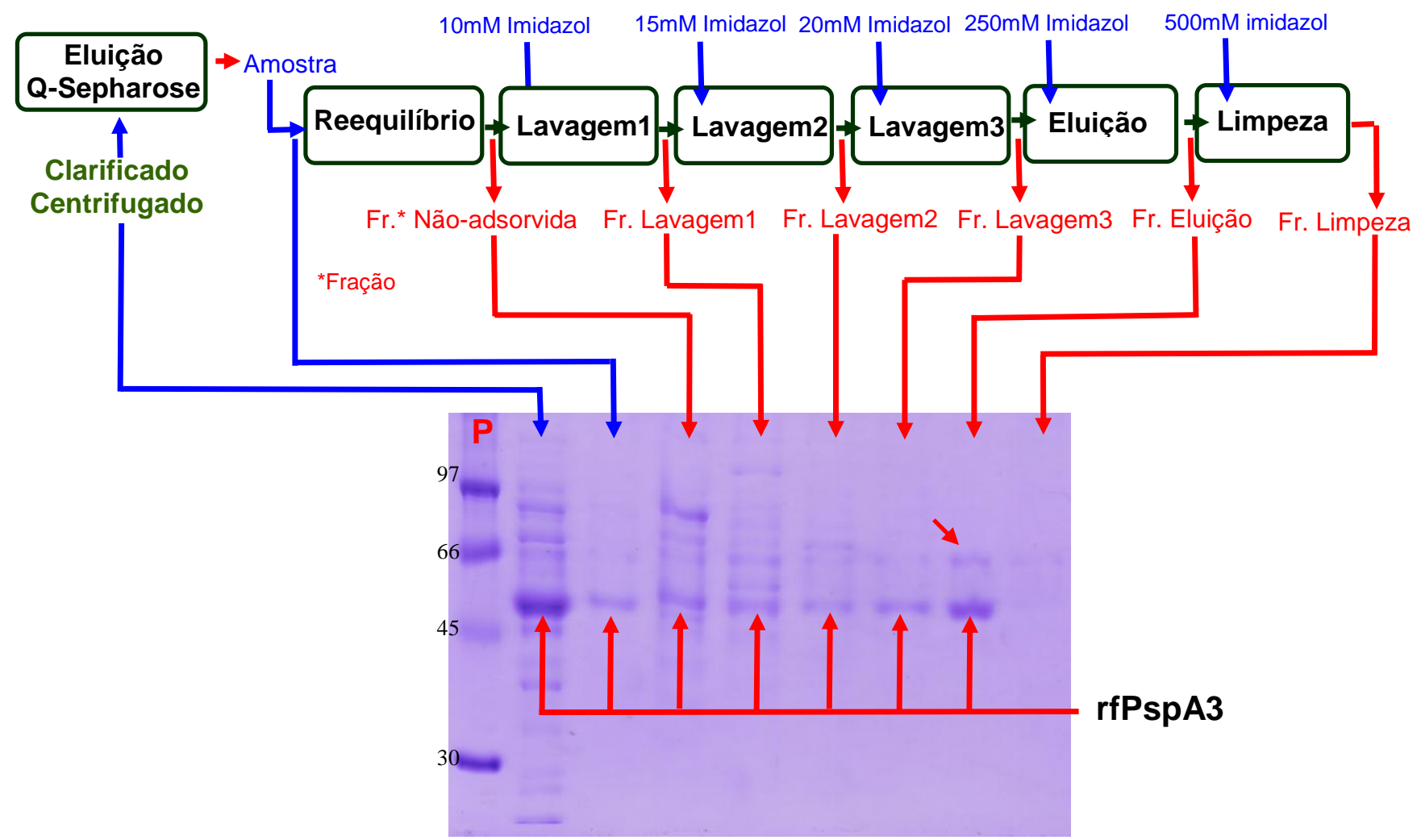

Figura 4.38: Fluxograma do segundo teste de em coluna empacotada com resina de afinidade IMACsepharose FF carregada com $\mathrm{Ni}^{+2}$ e abaixo o gel de eletroforese SDS-PAGE de cada fração obtida indicada pela seta e P-Padrão de massa molecular $(\mathrm{kDa})$. Setas azuis: entrada dos tampões e amostras anteriores a esta etapa de cromatografia que também foram analisadas e setas vermelhas: saída das frações, as quais foram analisadas por eletroforese SDS-PAGE. Fração de eluição com $2 \mu \mathrm{g}$ de proteínas totais e demais frações com $10 \mu \mathrm{g}$ de proteínas totais.

Segundo a Figura 4.38, em todas as etapas de lavagem houve perda de rfPspA3, sendo que, com até $15 \mathrm{mM}$ de imidazol houve eluição de impurezas, mas com $20 \mathrm{mM}$ houve perda da proteína relativamente pura. Assim, foi definida a etapa de lavagem com $15 \mathrm{mM}$ de imidazol. Em um terceiro teste, foi realizada a eluição com menor concentração de imidazol $(200 \mathrm{mM})$ na tentativa de recuperar todo rfPspA3 sem eluir a proteína de massa maior que o rfPspA3 indicada pela seta na Figura 4.38 presente na eluição com 250 mM. Nas mesmas condições dos testes 
anteriores, o terceiro foi realizado utilizando como material de partida a fração de eluição do terceiro teste em Q-Sepharose. Observou-se que durante a obtenção da fração não-adsorvida um segundo pico se formava ao final desta etapa, assim, foi obtida uma fração separada desse pico para análise.

A Figura 4.39 se refere ao terceiro teste em resina IMAC-Sepharose.

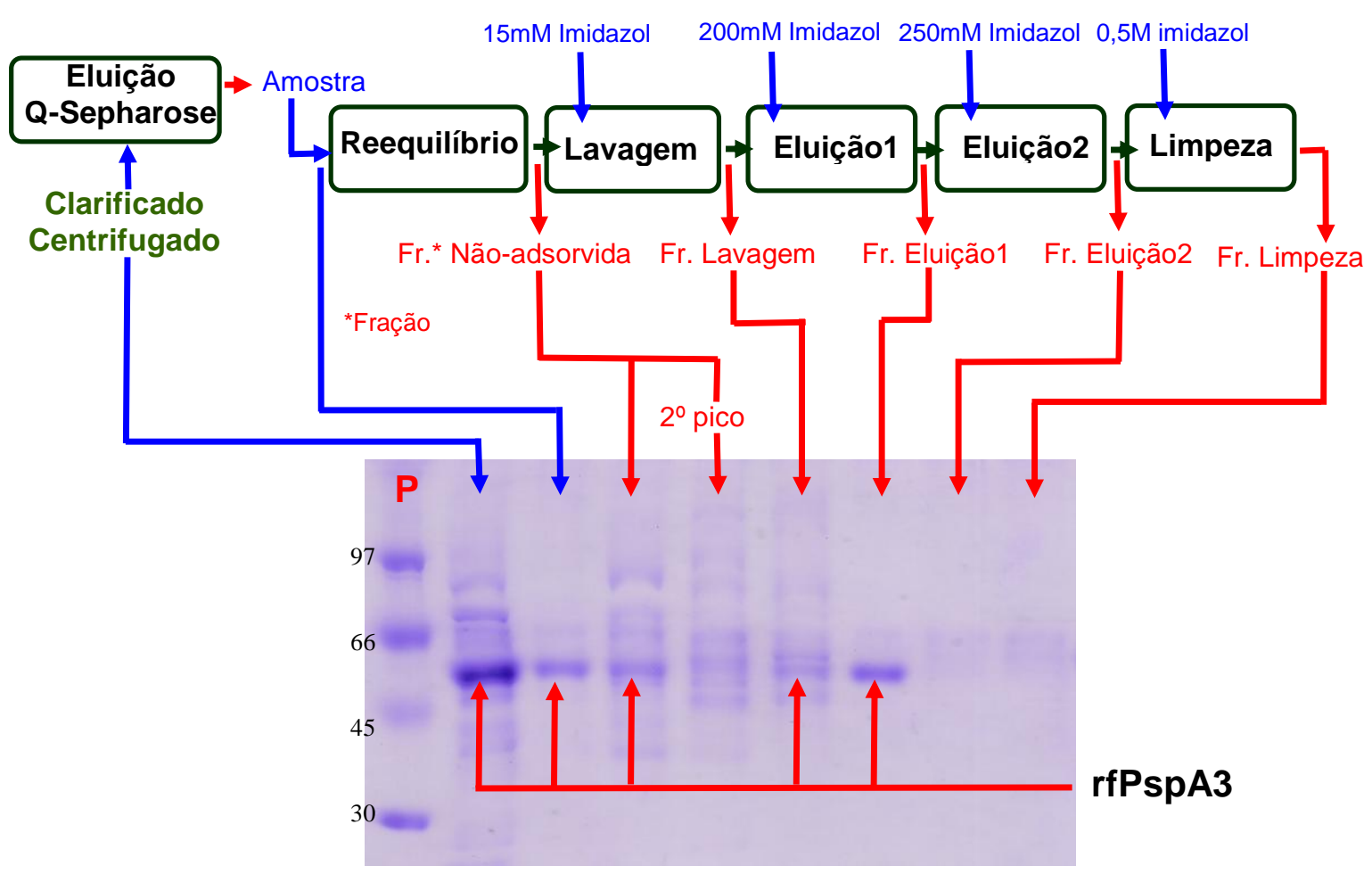

Figura 4.39: Fluxograma do terceiro teste em coluna empacotada com resina de afinidade IMACsepharose FF carregada com $\mathrm{Ni}^{+2}$ e abaixo o gel de eletroforese SDS-PAGE de cada fração indicada pela seta e P-Padrão de massa molecular $(\mathrm{kDa})$. Setas azuis: entrada dos tampões e amostras anteriores a esta etapa de cromatografia que também foram analisadas e setas vermelhas: saída das frações, as quais foram analisadas por eletroforese SDS-PAGE. Fração de eluição $1 \mathrm{com} 1 \mu \mathrm{g}$ e eluição $2 \mathrm{com} 5 \mu \mathrm{g}$ de proteínas totais e demais frações com $10 \mu \mathrm{g}$ de proteínas totais.

De acordo com a Figura 4.39, observou-se uma perda considerável de rfPspA3 na fração não-adsorvida com $5 \mathrm{mM}$ de imidazol, mas no $2^{\circ}$ pico obtido da fração não houve presença dessa proteína (Tabela 4.11). Na fração de $15 \mathrm{mM}$ de imidazol também se percebeu uma perda de rfPspA3 já observada no teste anterior. Nota-se também que foi possível recuperar toda proteína adsorvida pela resina na fração de eluição com 200 mM de imidazol. Novamente, tal como descrito no item 4.3.7.1 para a Q-Sepharose, a recuperação da rfPspA3 na fração de eluição foi baixa, mas a soma da proteína presente em todas as frações não alcança o total 
aplicado à resina, possivelmente devido a erros na quantificação da rfPspA3 por densitometria (Tabela 4.11).

Tabela 4.11: Tabela de purificação de rfPspA3 do terceiro teste de dessorção com a resina IMACsepharose.

\begin{tabular}{|c|c|c|c|c|}
\hline & $\mathrm{PT}^{\star}(\mathrm{mg})$ & $\begin{array}{c}\text { Quantidade } \\
\text { Relativa de } \\
\text { rfPspA3 (\%) }\end{array}$ & $\begin{array}{l}\text { rfPspA3 } \\
\text { (mg) }\end{array}$ & $\begin{array}{c}\text { Rendimento } \\
(\%)\end{array}$ \\
\hline Eluição Q-Sepharose & 71,08 & 80,6 & 57,3 & 100 \\
\hline Fração não-adsorvida & 35,86 & 42,6 & 15,3 & 26,7 \\
\hline $2^{\circ}$ Pico FNA*** & 2,60 & 13,5 & 0,4 & 0,7 \\
\hline Lavagem 15 mM imidazol & 13,28 & 21,5 & 2,9 & 5,0 \\
\hline Eluição 200 mM imidazol & 22,35 & 86,4 & 19,3 & 33,7 \\
\hline Eluição 250 mM imidazol & 4,61 & 33,3 & 1,5 & 2,6 \\
\hline Limpeza 500 mM imidazol & 4,15 & 37,2 & 1,5 & 2,6 \\
\hline
\end{tabular}

\subsubsection{Estabelecimento da seqüência das cromatografias em Q-Sepharose e IMAC-Sepharose carregada com $\mathrm{Ni}^{+2}$}

Após estabelecer previamente as condições das cromatografias em $\mathrm{Q} e$ IMAC-Sepharose, foram feitos dois esquemas de purificação, detalhados na Figura 4.40 para estabelecer em qual sequência obtêm-se maior rendimento do processo. A etapa de clarificação foi feita por centrifugação.

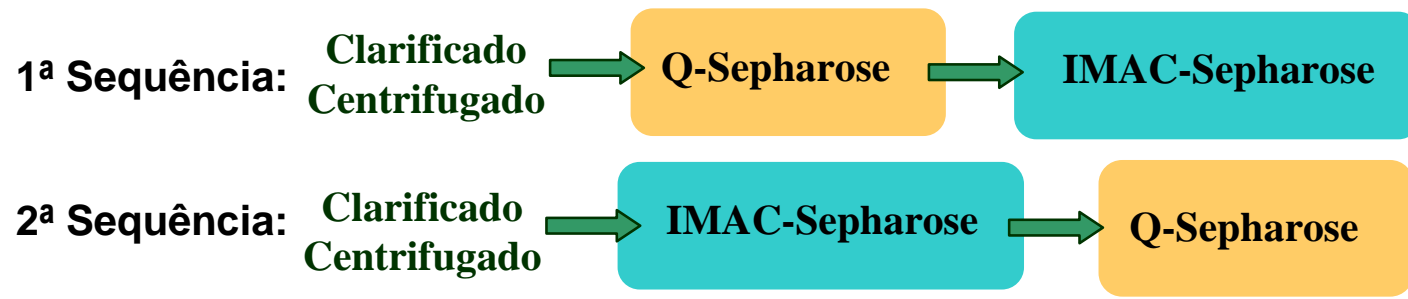

Figura 4.40: Esquemas dos processos de purificação de rfPspA3 testados para estabelecer a sequência das etapas cromatográficas.

O lisado de células ( 100 g massa úmida) obtido foi centrifugado e, após essa etapa foi dividido igualmente em dois volumes, obtendo-se assim o material de partida dos dois esquemas propostos. O volume inicial de cada teste foi de $1000 \mathrm{~mL}$. O volume de coluna utilizado na cromatografia Q-sepharose foi de $250 \mathrm{~mL}$, enquanto que foram utilizados $500 \mathrm{~mL}$ para a IMAC-Sepharose, quantidades necessárias para as duas cromatografias de acordo com a capacidade de cada resina em relação à quantidade de proteínas totais da amostra. 
As condições das cromatografias estão detalhadas nas Figuras 4.41 e 4.42.

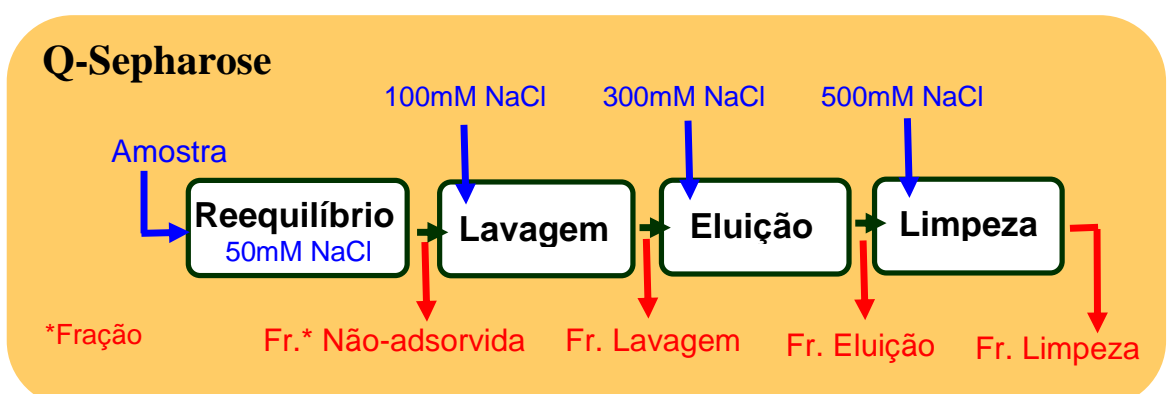

Figura 4.41: Condições da cromatografia utilizando coluna com $250 \mathrm{~mL}$ de Q-Sepharose Fast-Flow para estabelecer a sequência das etapas de purificação de rfPspA3.

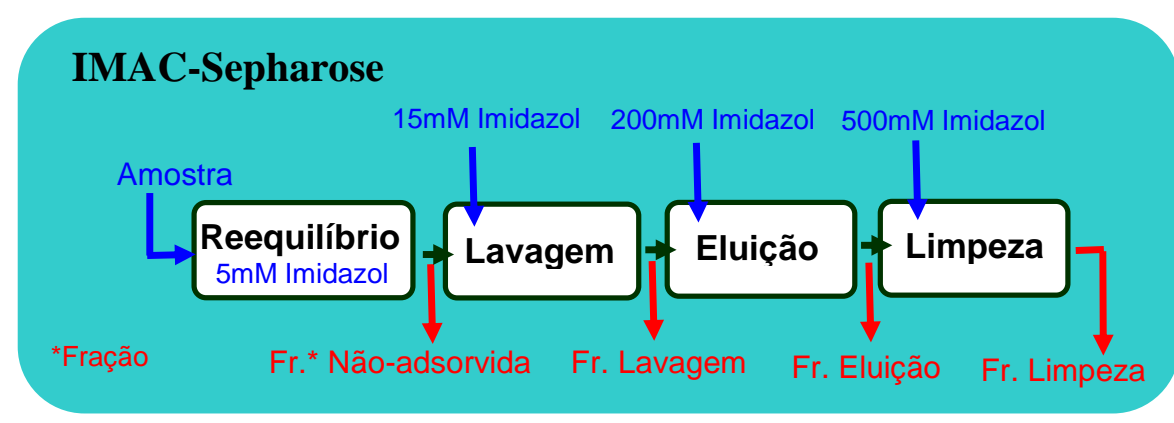

Figura 4.42: Condições da cromatografia utilizando $500 \mathrm{~mL}$ de IMAC-Sepharose Fast-Flow carregada com $\mathrm{Ni}^{+2}$ para estabelecer a sequência das etapas de purificação de rfPspA3.

Foi realizada a primeira sequência utilizando a Q-Seharose como primeira etapa cromatográfica seguida pela IMAC-Sepharose empregando as condições prédeterminadas indicadas nas Figuras 4.41 e 4.42 . Observa-se no gel de eletroforese da Figura 4.43 que foram recolhidas duas frações de eluição na cromatografia com IMAC-Sepharose, pois no cromatograma apareceram dois picos que foram recolhidos separadamente.

Amostras de todas as frações foram submetidas à cromatografia líquida de alta pressão (HPLC) utilizando coluna em gel filtração (high performance size exclusion chromatography, HPSEC) para determinação da pureza. A partir desses dados foi possível montar a Tabela 4.12 com os dados de pureza do rfPspA3. 


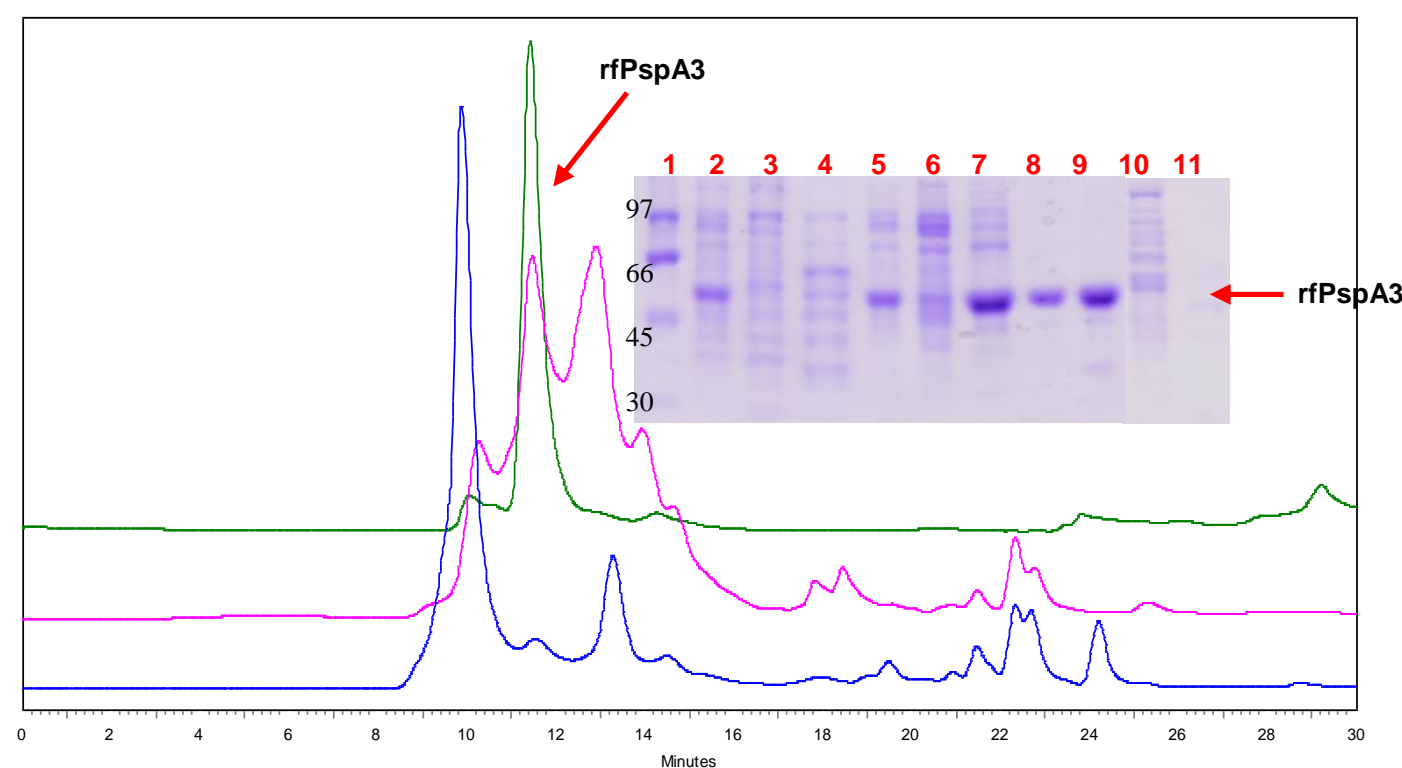

Figura 4.43: Cromatogramas HPSEC e SDS-PAGE das frações da primeira sequência cromatográfica em Q-Sepharose seguida de IMAC-Sepharose. Cromatogramas em escala arbitrária: azul-Homogenato Clarificado, rosa-eluição $Q$, verde-pool da eluição IMAC, tempo de retenção da rfPspA3 = 11-12min. Caneletas SDS-PAGE: 1-Padrão de massa molecular $(\mathrm{kDa})$; 2-Clarificado centrifugado (10 $\left.\mu \mathrm{g} \mathrm{PT}{ }^{*}\right)$; 3-Fração não-

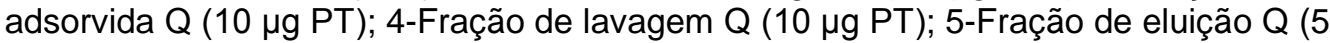
$\mu \mathrm{g}$ PT); 6-Fração não-adsorvida IMAC (10 $\mu \mathrm{g}$ PT); 7-Fração de lavagem IMAC (10 $\mu \mathrm{g}$ PT); 8-Fração de eluição-primeira fração IMAC (2 $\mu \mathrm{g}$ PT); 9-Fração de eluição-

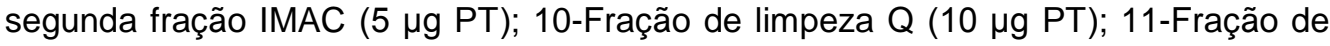
limpeza IMAC (10 $\mu \mathrm{g}$ PT). *PT = Proteínas totais.

Tabela 4.12: Tabela de purificação de rfPspA3 em Q-Sepharose seguida de IMAC-Sepharose.

\begin{tabular}{lccccc}
\hline & $\begin{array}{c}\text { Proteínas } \\
\text { Totais }(\mathbf{m g})\end{array}$ & $\begin{array}{c}\text { P. R. }{ }^{1} \\
\text { rfPspA3 }(\%)\end{array}$ & $\begin{array}{c}\text { rfPspA3 } \\
(\mathbf{m g})\end{array}$ & $\begin{array}{c}\text { Recuperação de } \\
\text { rfPspA3 (\%) }\end{array}$ & $\begin{array}{c}\text { Fator de } \\
\text { Purificação }\end{array}$ \\
\hline Clarificado Centrifugado & 12771 & 6,26 & $1240,4^{\star *}$ & 100 & 1,0 \\
Q-Sepharose & 3963 & 28,61 & 1133 & 91,4 & 4,6 \\
IMAC-Sepharose & 1068 & 81,06 & 867 & $69,9(76,5)^{*}$ & $12,9(2,8)^{*}$ \\
\hline
\end{tabular}

'Pureza Relativa obtida por HPSEC

*Valores entre parênteses referem-se à recuperação e ao fator de purificação da etapa e fora, do processo todo.

** Calculado pela soma das frações não adsorvida, lavagem, eluição e limpeza devido ao fato de a concentração de rfPspA3 nessa amostra estar subestimada.

A pureza relativa obtida por HPSEC foi mais baixa que a normalmente medida por densitometria do gel de eletroforese. Isso ocorreu porque o coeficiente de extinção da rfPspA3 a $280 \mathrm{~nm}$ é muito baixo $(1,0 \mathrm{~g} / \mathrm{L}=0,196$, item 4.2), fazendo com que a área da rfPspA3 seja subestimada em relação à área dos outros picos obtidos no cromatograma (Figura 4.43, linha azul).

Nota-se pela Tabela 4.12 que na primeira etapa em Q-Sepharose ocorreu redução considerável da quantidade de proteínas totais na fração de eluição 
( 8700 mg), obtendo-se assim bom fator de purificação $(4,6)$. Observa-se também pela tabela que após a etapa cromatográfica de IMAC-Sepharose consegue-se obter alto grau de purificação (81,06\%) com $\sim 70 \%$ de recuperação da proteína de interesse. Porém, a pureza requerida de $95 \%$, por se tratar de uma biomolécula para uso injetável em humanos, ainda não foi atingida.

Assim como na primeira sequência, foram utilizadas para a segunda sequência as mesmas condições cromatográficas indicadas nas Figuras 4.41 e 4.42 utilizando a resina IMAC-Sepharose carregada com $\mathrm{Ni}^{+2}$ como primeira etapa cromatográfica seguida da Q-Sepharose. A Figura 4.44 e a Tabela 4.13 indicam os resultados destas etapas de purificação.

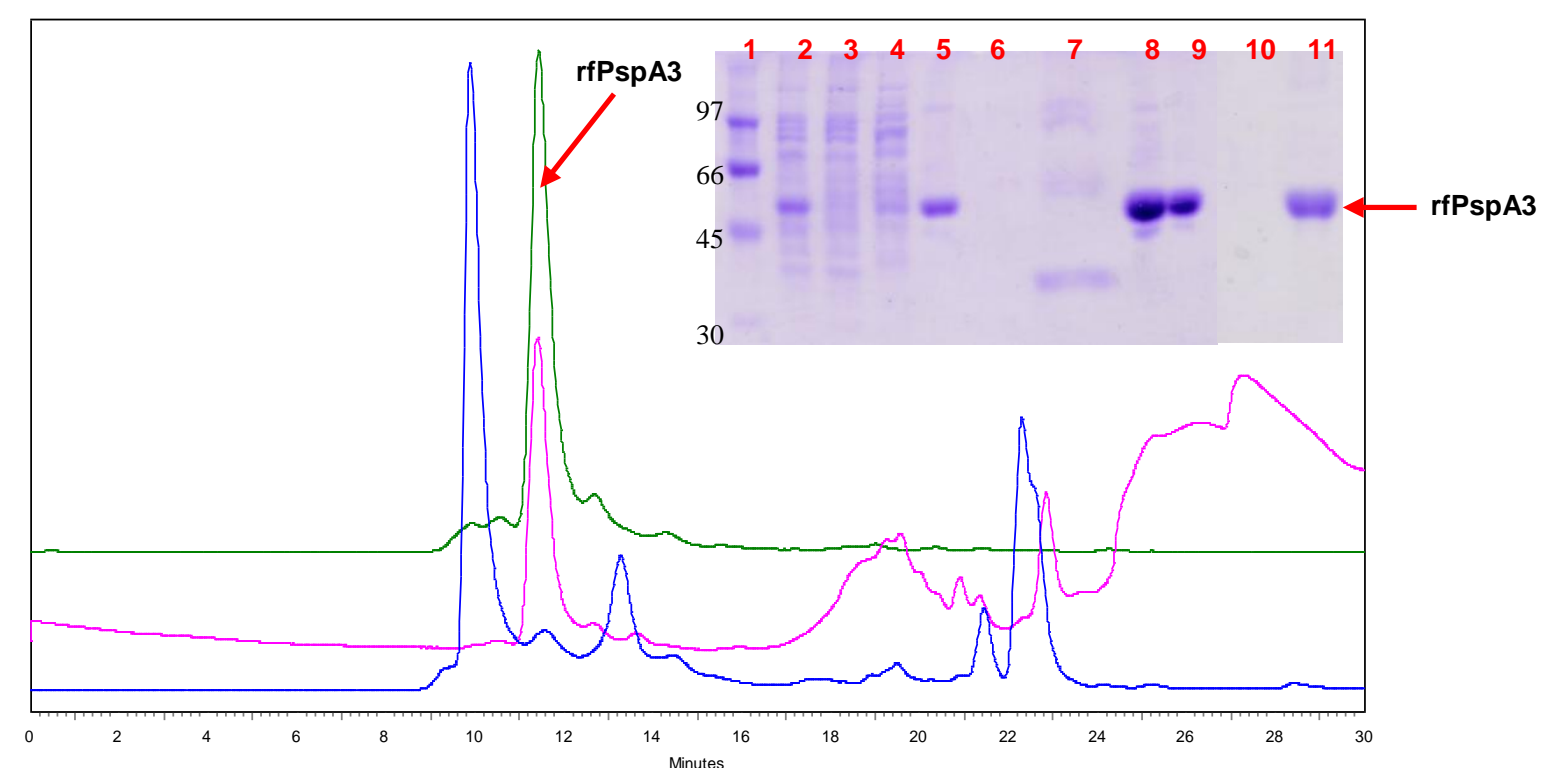

Figura 4.44: Cromatogramas HPSEC $e^{\text {Minutes }}$ SDS-PAGE das frações da segunda sequência de cromatografias em IMAC-Sepharose seguida de Q-Sepharose. Cromatogramas em escala arbitrária: azul-Homogenato Clarificado, rosa-eluição IMAC, verde-pool da eluição Q. Caneletas SDS-PAGE: 1-Padrão de massa molecular $(\mathrm{kDa})$; 2-Clarificado centrifugado (10 $\mu \mathrm{g} \mathrm{PT*);} \mathrm{3-Fração} \mathrm{não-adsorvida} \mathrm{IMAC} \mathrm{(10} \mathrm{\mu g} \mathrm{PT);} \mathrm{4-Fração} \mathrm{de}$ lavagem IMAC (10 $\mu \mathrm{g}$ PT); 5-Fração de eluição IMAC-Sepharose (5 $\mu \mathrm{g}$ PT); 6-Fração

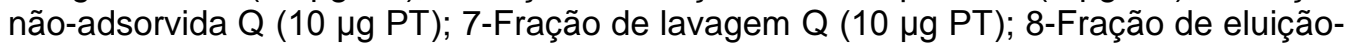
primeira fração Q (2 $\mu \mathrm{g} \mathrm{PT})$; 9-Fração de eluição-segunda fração Q (5 $\mu \mathrm{g} \mathrm{PT})$; 10 -

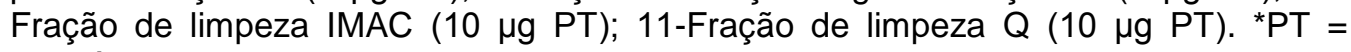
Proteínas totais. 
Tabela 4.13: Tabela de purificação de rfPspA3 em IMAC-Sepharose seguida de Q-Sepharose.

\begin{tabular}{|c|c|c|c|c|c|}
\hline & $\begin{array}{l}\text { Proteínas } \\
\text { Totais }(\mathrm{mg})\end{array}$ & $\begin{array}{c}\text { P. R. } \\
\text { rfPspA3 (\%) }\end{array}$ & $\begin{array}{c}\text { rfPspA3 } \\
\text { (mg) }\end{array}$ & $\begin{array}{l}\text { Recuperação } \\
\text { de rfPspA3 (\%) }\end{array}$ & $\begin{array}{c}\text { Fator de } \\
\text { Purificação }\end{array}$ \\
\hline Clarificado Centrifugado & 13414 & 7,48 & $1521,5^{\star \star}$ & 100 & 1,0 \\
\hline IMAC-Sepharose & 2860 & 46,63 & 1334 & 87,7 & 6,4 \\
\hline Q-Sepharose & 987 & 75,8 & 747 & $49,1(56,0)^{*}$ & $10,1(1,6)^{*}$ \\
\hline
\end{tabular}

Podemos observar na Figura 4.44 que mesmo após a eluição em 300 mM de $\mathrm{NaCl}$ da cromatografia em Q-Sepharose após a IMAC, houve presença de rfPspA3 na fração de limpeza. Isto indica a necessidade de aumentar a concentração salina para recuperar toda a proteína na fração eluída, pois como a amostra está mais pura, pode ser que a força de interação entre a proteína e a resina esteja maior, sendo assim necessária maior condutividade para que essa interação seja revertida.

Utilizando Q-Sepharose após IMAC-Sephorese, foi obtida uma recuperação mais baixa $(49,1 \%)$ que a obtida pela sequência inversa $(69,9 \%)$. O valor menor ocorreu, em parte, devido a partição da eluição da rfPspA3 nas frações com 300 mM (747 mg de rfPspA3) e $500 \mathrm{mM}$ de $\mathrm{NaCl}$ (88 mg de rfPspA3). Observou-se também que utilizando IMAC-Sepharose como a primeira etapa cromatográfica obteve-se fator de purificação maior $(6,4)$ do que quando se utilizou a Q-Sepharose $(4,6)$. Porém, ao final da segunda etapa obteve-se uma pureza relativa de rfPspA3 $\sim 6 \%$ maior $(81,06 \%)$ na primeira sequência cromatográfica contra $75,8 \%$ da segunda sequência estudada.

\subsubsection{Estudos para estabelecer a terceira etapa de purificação}

Após a segunda etapa cromatográfica, a pureza requerida de $95 \%$ do rfPspA3 não foi alcança e uma nova etapa de purificação seria necessária. Foram propostas, além da precipitação por ponto isoelétrico, 3 cromatografias com diferentes propriedades: Phenyl-Sepharose de interação hidrofóbica, Sephacryl S200 de gel filtração e SP-Sepharose de troca catiônica. Esta última, anteriormente descartada como primeira etapa cromatográfica por necessitar de um $\mathrm{pH}$ de 
adsorção abaixo do pl do rfPspA3, o que fazia com que a amostra precipitasse perdendo uma quantidade expressiva de rfPspA3, foi novamente cogitada após a tentativa de precipitação isoelétrica do rfPspA3.

\subsubsection{Sephacryl S-200 HR como possível terceira etapa cromatográfica}

Os testes com a Sephacryl S-200 HR foram realizados com amostras da fração de eluição da segunda cromatografia (IMAC-Sepharose). A amostra foi concentrada e dialisada com o tampão eluente (50 mM fosfato $+150 \mathrm{mM}$ de $\mathrm{NaCl}$ ) e $15 \mathrm{~mL}$ de amostra foi adicionada na coluna. A Figura 4.45 mostra o cromatograma (A) e as frações obtidas que foram analisadas em gel de eletroforese SDS-PAGE (B1 e B2).

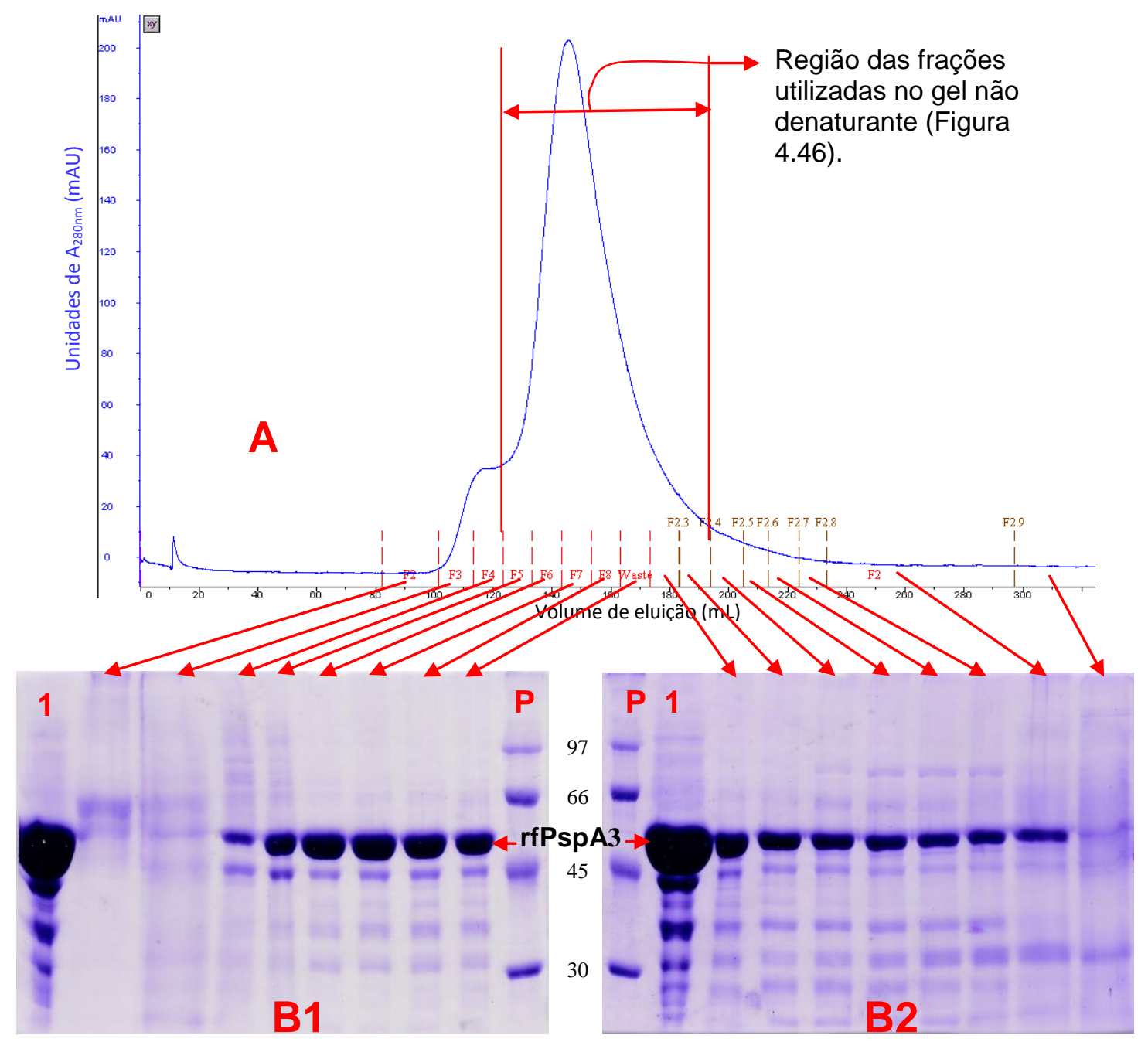

Figura 4.45: A-Cromatograma da purificação em Sephacryl S-200 HR da amostra de eluição da segunda cromatografia IMAC-Sepharose. B1 e B2-Géis de eletroforese SDS-PAGE das frações coletadas a partir de $80 \mathrm{~mL}$ de eluição até $330 \mathrm{~mL}$ indicadas pelas setas em vermelho. P-Padrão de massa molecular $(\mathrm{kDa})$ e 1-Amostra inicial concentrada e dialisada. Foram adicionados $5 \mu \mathrm{g}$ de proteínas totais de todas as amostras. 
Observou-se no cromatograma da Figura 4.45 a presença de um ombro antes da eluição do pico principal. A eletroforese mostrou que o ombro era de uma proteína de massa $\sim 60 \mathrm{kDa}$, enquanto que o pico principal correspondeu ao rfPspA3, porém, não houve separação satisfatória do rfPspA3 das demais proteínas (Figura 4.45, B1 e B2). Uma possível explicação seria que as proteínas de menor peso molecular estariam agregadas. Diante desta hipótese, foi feita uma eletroforese SDS-PAGE não redutora, ou seja, sem $\beta$-mercaptoetanol (Figura 4.46) somente do pico principal do cromatograma indicado pelas duas barras vermelhas na Figura $4.45 \mathrm{~A}$.

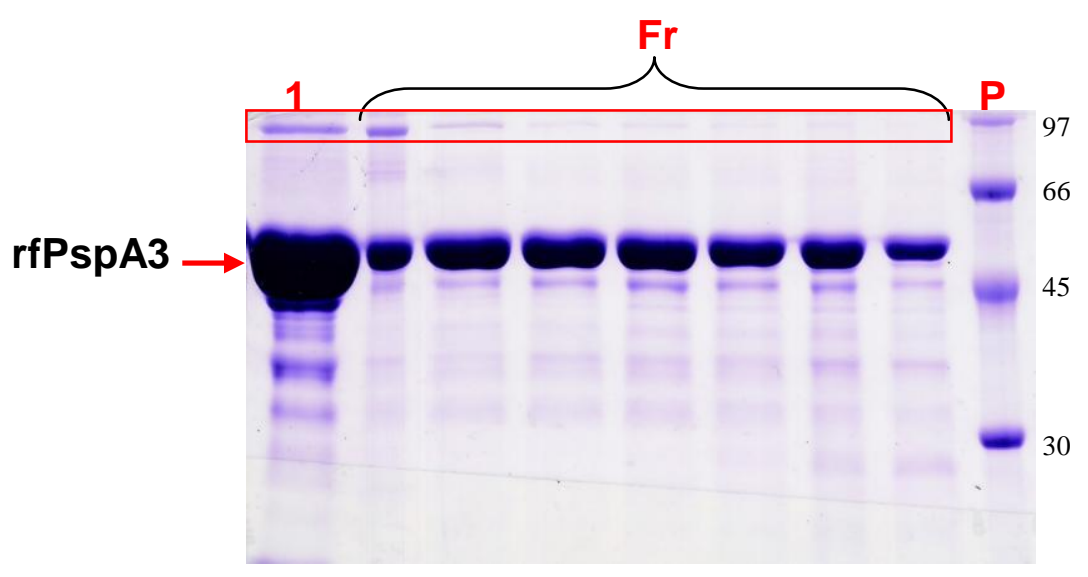

Figura 4.46: Gel de eletroforese SDS-PAGE não redutor das frações obtidas do pico principal do cromatograma (Figura $4.42 \mathrm{~A}$ ). P-Padrão de massa molecular (kDa); 1-Amostra inicial concentrada e dialisada; Fr-Frações do pico principal (eluição de 124 a $194 \mathrm{~mL}$ ) do cromatograma da Figura $4.45 \mathrm{~A}$. Foram adicionados $5 \mu \mathrm{g}$ de proteínas totais de todas as amostras.

De acordo com a Figura 4.46 apareceram bandas em torno de $97 \mathrm{KDa}$ (quadro vermelho) que não estavam presentes nos géis mostrados na Figura 4.45 B1 e B2 . Essas bandas podem ser dímeros de rfPspA3 presentes na amostra, pois são em valor aproximado a 2 vezes a massa molecular $\operatorname{rfPspA3}$, isto poderia explicar a presença do pico anterior ao pico majoritário da rfPspA3 no cromatograma da Figura $4.45 \mathrm{~A}$.

Devido a incapacidade desta cromatografia de separar as impurezas da rfPspA3, a opção de usá-la como terceira etapa cromatográfica de purificação foi descartada. Rolland et al. ${ }^{52}$, em estudos com diferentes estratégias de purificação de proteínas recombinantes do vírus causador da Hepatite $B$, comparou ultracentrifugação ou filtração em gel como última etapa cromatográfica e mostrou que a resolução desta cromatografia é pior que a da ultracentrifução. 


\subsubsection{Phenyl-Sepharose High Sub Fast-Flow como possível terceira etapa cromatográfica}

- Testes de adsorção em tubos

Para os testes em adsorção em tubos foi utilizada uma amostra da eluição da segunda cromatografia, IMAC-Sepharose. Os testes foram feitos em tampão fosfato de sódio $10 \mathrm{mM}$ com diferentes concentrações dos sais $\mathrm{NaCl}$ e $\left(\mathrm{NH}_{4}\right)_{2} \mathrm{SO}_{4}$ como mostra a Tabela 4.14.

Tabela 4.14: Concentrações dos sais $\mathrm{NaCl}$ e $\left(\mathrm{NH}_{4}\right)_{2} \mathrm{SO}_{4}$ utilizados no teste de adsorção em tubos à resina Phenyl-Sepharose.

\begin{tabular}{cc}
\hline $\mathrm{NaCl}(\mathrm{M})$ & $\left(\mathrm{NH}_{4}\right)_{2} \mathrm{SO}_{4}(\mathrm{M})$ \\
\hline 1,0 & 0,75 \\
2,0 & 1,0 \\
3,0 & 1,25 \\
- & 1,50 \\
\hline
\end{tabular}

Nas concentrações de 1,25 e 1,50 M de $\left(\mathrm{NH}_{4}\right)_{2} \mathrm{SO}_{4}$ os testes não foram realizados, pois a amostra precipitou ao adicionar o sal. Com $3 \mathrm{M}$ de $\mathrm{NaCl}$ também não foi possível a realização do teste por este não ter dissolvido completamente na amostra. Os resultados da adsorção nas demais condições estão apresentados na Figura 4.47.

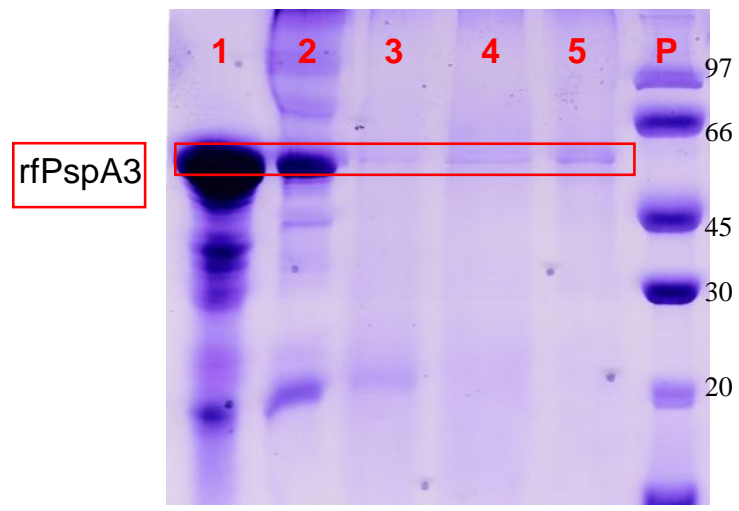

Figura 4.47: Gel de eletroforese do teste de adsorção em tubos com a resina Phenyl-Sepharose. PPadrão de massa molecular (kDa); 1 -Amostra inicial da eluição da IMAC-Sepharose (2 cromatografia); 2-Fração não adsorvida com $1 \mathrm{M}$ de NaCl; 3-Fração não adsorvida com $2 \mathrm{M}$ de NaCl; 4-Fração não adsorvida com $0,75 \mathrm{M}$ de $\left(\mathrm{NH}_{4}\right)_{2} \mathrm{SO}_{4}$; 5-Fração não adsorvida com $1 \mathrm{M}$ de $\left(\mathrm{NH}_{4}\right)_{2} \mathrm{SO}_{4}$. Foram adicionadas $15 \mu \mathrm{g}$ de proteínas totais de todas as amostras. 
De acordo com a Figura 4.47 observa-se que $1 \mathrm{M}$ de $\mathrm{NaCl}$ não é suficiente para que todo o rfPspA3 seja adsorvido pela resina hidrofóbica. Porém, a adsorção foi semelhante nas demais condições testadas, nas quais houve também adsorção significativa das impurezas.

\section{- Testes de dessorção em coluna empacotada}

Foram realizados, inicialmente, dois testes: um utilizando para adsorção $2 \mathrm{M}$ de $\mathrm{NaCl}$ e outro $1 \mathrm{M}$ de $\left(\mathrm{NH}_{4}\right)_{2} \mathrm{SO}_{4}$. O tampão utilizado foi Tris $25 \mathrm{mM}$ em pH entre 7,5-8,0 e a amostra foi a mesma utilizada para o teste de adsorção em tubos.Os resultados dos testes de dessorção estão apresentados na Figura 4.48 A e B.
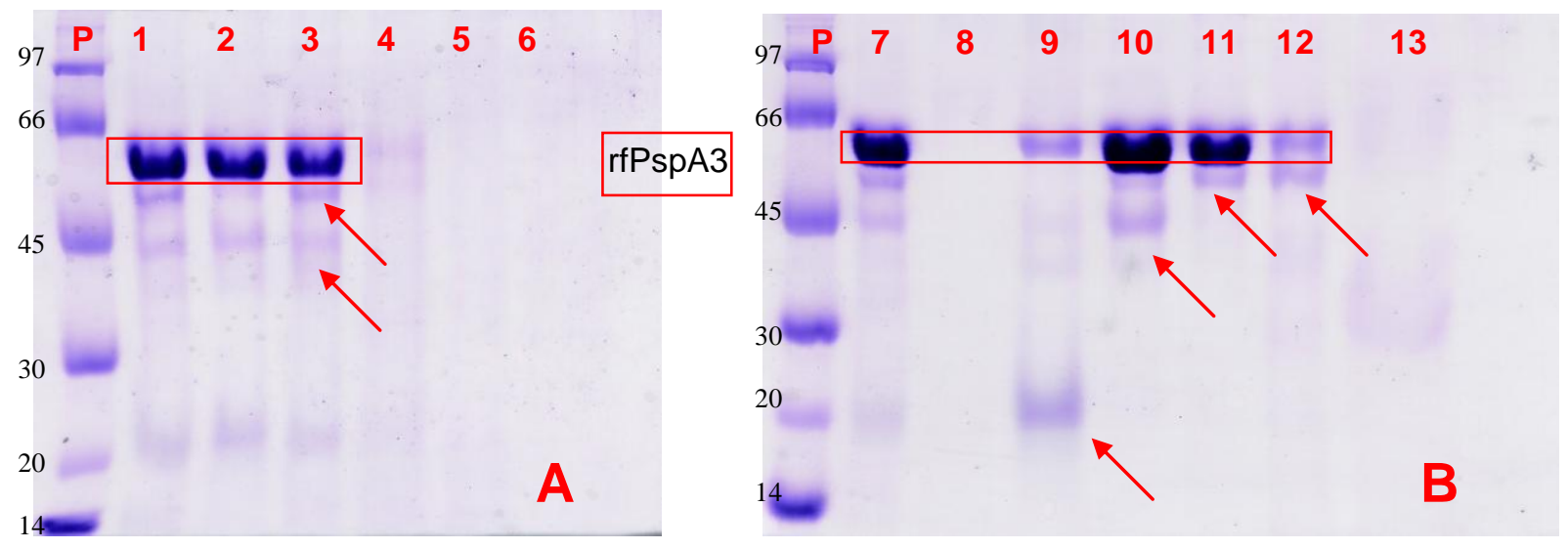

Figura 4.48: Géis de eletroforese dos testes de dessorção em coluna empacotada com resina Phenyl-Sepharose High Sub Fast Flow. A-Teste realizado com NaCl: 1-Amostra inicial, eluição da segunda cromatografia: IMAC-Sepharose; 2-Fração não adsorvida; 3Fração de eluição com $1 \mathrm{M}$ de NaCl; 4-Pool das frações de eluição com 750 e 500 mM de $\mathrm{NaCl}$; 5-Fração de eluição com $250 \mathrm{mM}$ de $\mathrm{NaCl}$ e 6-Fração de eluição sem $\mathrm{NaCl}$. B-Teste realizado com $\left(\mathrm{NH}_{4}\right)_{2} \mathrm{SO}_{4}$ : 7-Amostra inicial, eluição da segunda cromatografia: IMAC-Sepharose; 8-Fração não adsorvida; 9-Fração de eluição com 800 mM de $\left(\mathrm{NH}_{4}\right)_{2} \mathrm{SO}_{4} ; 10$-Fração de eluição com $600 \mathrm{mM}$ de $\left(\mathrm{NH}_{4}\right)_{2} \mathrm{SO}_{4} ; 11$-Fração de eluição com $400 \mathrm{mM}$ de $\left(\mathrm{NH}_{4}\right)_{2} \mathrm{SO}_{4} ; 12$-Fração de eluição com $100 \mathrm{mM}$ de $\left(\mathrm{NH}_{4}\right)_{2} \mathrm{SO}_{4} ; 13$ Fração de eluição sem $\left(\mathrm{NH}_{4}\right)_{2} \mathrm{SO}_{4}$ e P-Padrão de massa molecular (kDa). Foram aplicados $5 \mu \mathrm{g}$ de proteínas totais de cada amostra. As setas vermelhas indicam as bandas de impurezas nas frações.

Observa-se pela Figura 4.48 que em nenhum dos dois testes conseguiu-se separar impurezas das frações obtidas. No teste com $\mathrm{NaCl}$ houve perda de rfPspA3 na fração não adsorvida indicando que $2 \mathrm{M}$ de $\mathrm{NaCl}$ não foram suficientes para expor as partes hidrofóbicas da proteína para que ela fosse totalmente adsorvida pela resina. A fração não adsorvida no teste com $\left(\mathrm{NH}_{4}\right)_{2} \mathrm{SO}_{4}$ não apresentou nenhuma impureza indicando total adsorção de todas as proteínas pela resina, e de 
acordo com a Figura $4.48 \mathrm{~B}$, as frações em diferentes concentrações deste sal apresentaram pelo menos uma impureza.

Diante destes resultados, foi feito outro teste com $\mathrm{NaCl}$ aumentando sua concentração inicial de adsorção para $2,5 \mathrm{M}$ e realizando a dessorção nas concentrações de 1,5, 1,0, 0,5 e 0,0 M de NaCl no mesmo tampão e pH. Porém, da mesma maneira que o observado anteriormente com $\left(\mathrm{NH}_{4}\right)_{2} \mathrm{SO}_{4}$ (Figura $4.48 \mathrm{~B}$ ), não houve separação das impurezas, indicando não ser esta uma boa opção como última etapa cromatográfica.

\subsubsection{Recuperação do rfPspA3 por precipitação isoelétrica}

Precipitação isoelétrica é uma técnica de baixo custo e seletiva por valer-se do $\mathrm{pH}$ em que a proteína tem sua carga total nula, o que diminui sua solubilidade $\mathrm{e}^{53}$. Assim, o rfPspA3 seria recuperado do precipitado ressuspendendo-o o com tampão em $\mathrm{pH}$ 8,0. Porém, de acordo com a eletroforese apresentada na Figura 4.49, o resultado do teste de precipitação foi o contrário do esperado.

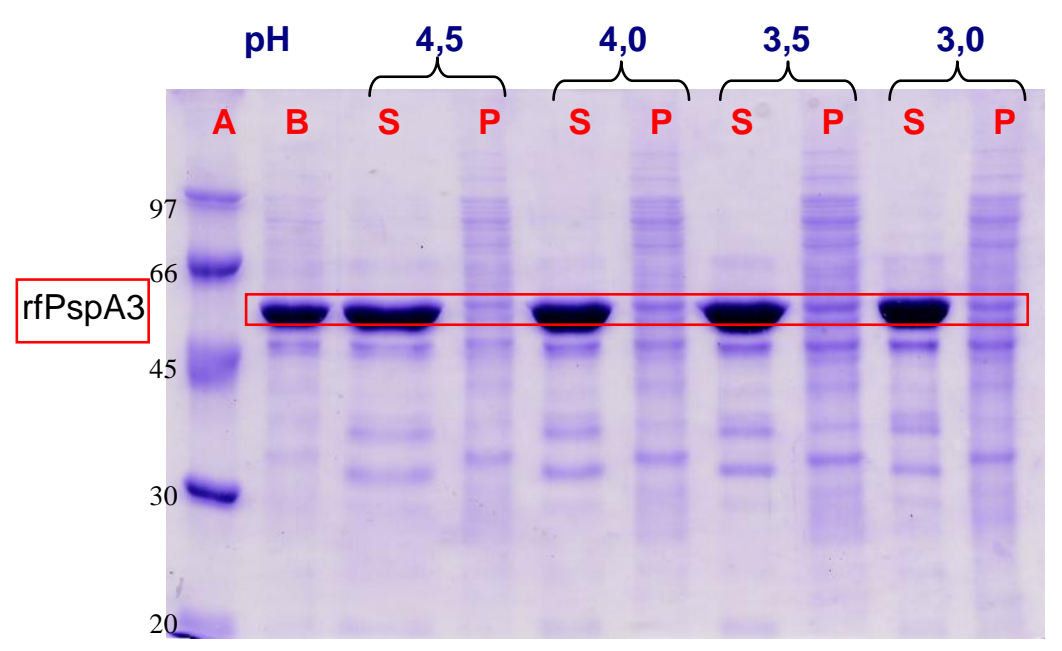

Figura 4.49: Gel de eletroforese do teste de precipitação isoelétrica com amostra purificada em duas etapas cromatográficas. A-Padrão de massa molecular $(\mathrm{kDa})$; B-Amostra inicial em $\mathrm{pH}$

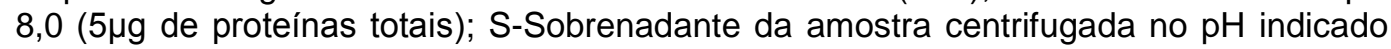

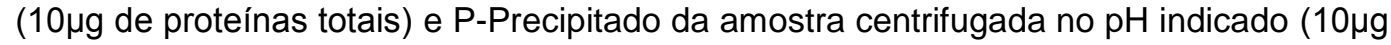
de proteínas totais).

De acordo com a Figura 4.49, a maior parte da proteína ficou solúvel no sobrenadante mesmo abaixo de seu pl $(4,74)$. Segundo Lucarini, et al. ${ }^{54}$ proteínas hidrofílicas como no caso da albumina e do rfPspA3 dificilmente precipitam totalmente em seu ponto isoelético. Porém, mesmo com a maior parte do rfPspA3 
presente no sobrenadante, há uma perda desta proteína no precipitado, chegando a $12,7 \%$ com pH 3,0 e 8,8\% com pH 4,5, uma perda alta (30 e 6\%, respectivamente) se tratando de uma amostra com uma pureza relativa elevada (73,5\%), e também não houve um aumento expressivo da pureza relativa, chegando a $82 \% \mathrm{com} \mathrm{pH} 3,0$ (dados obtidos por densitometria). Alguns trabalhos adicionam componentes ou deixam as proteínas em condições mais favoráveis para que a solubilidade delas diminua em $\mathrm{pH}$ próximo ao $\mathrm{pl}^{55,56}$. Segundo Bramaud et al. ${ }^{55}$, o aumento de temperatura associado a adição de ácido cítrico aumenta a formação de complexos com a proteína $\alpha-L A$ favorecendo a precipitação em temperaturas de $50{ }^{\circ} \mathrm{C}$. Porém, essas técnicas aumentam a probabilidade de desnaturação protéica, isso seria prejudicial como última etapa cromatográfica, pois, a proteína poderia nessa etapa final perder sua função devido à desnaturação.

Com este resultado, a etapa de precipitação foi descartada, mas novamente foi cogitado o uso da SP-Sepharose (troca-catiônica) como terceira etapa cromatográfica, uma vez demonstrado por este teste ser possível manipular a amostra com uma pureza relativa mais alta em pH próximo ao pl.

\subsubsection{SP-Sepharose Fast-Flow como possível terceira etapa cromatográfica}

\section{- Testes de adsorção em tubos}

Inicialmente foram utilizadas as amostras do sobrenadante do teste de precipitação isoelétrica para adsorção em tubos com a resina SP-Sepharose. Os resultados deste teste estão apresentados na Figura 4.50.

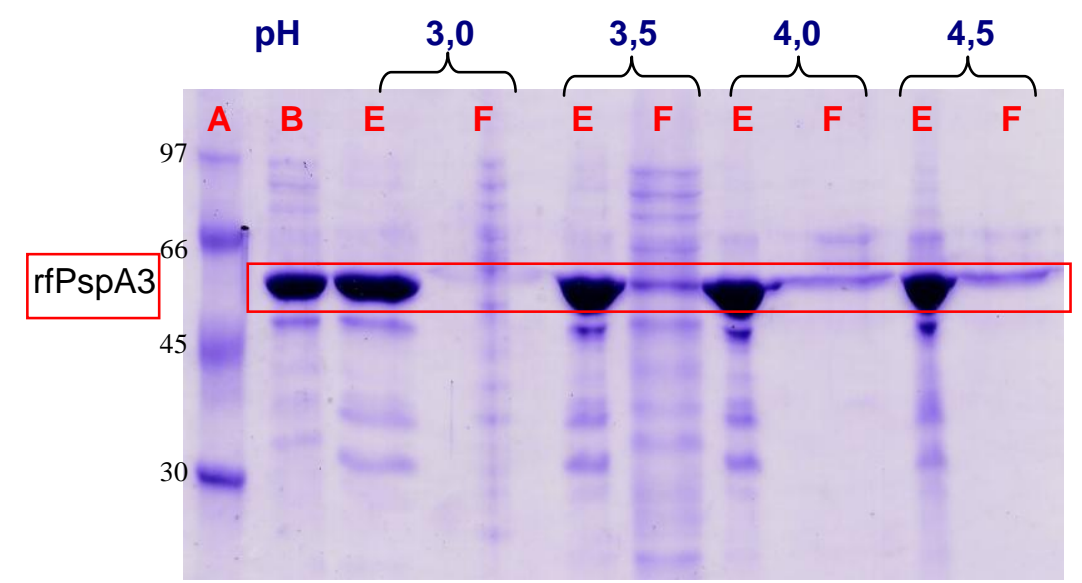

Figura 4.50: Gel de eletroforese do teste de adsorção em tubos com resina SP-Sepharose. A-Padrão

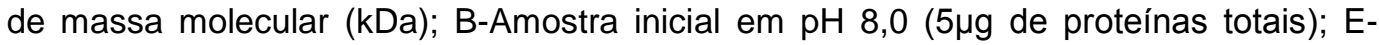
Amostra de entrada (inicial) no $\mathrm{pH}$ indicado ( $5 \mu \mathrm{g}$ de proteínas totais) e F-Fração não adsorvida em resina SP-Sepharose no $\mathrm{pH}$ indicado (10 $\mathrm{\mu g}$ de proteínas totais). 
A Figura 4.50 mostra que à medida que aumentou o pH da amostra houve maior presença de rfPspA3 na fração não adsorvida e menor presença de impurezas, ou seja, a adsorção de impurezas aumentou com o aumento de $\mathrm{pH}$, fazendo com que a pureza relativa do rfPspA3 na fração não adsorvida aumentasse, chegando a $57,3 \%$ com $\mathrm{pH} 4,5$. Porém, como a quantidade de proteínas totais presentes nestas frações não adsorvidas foi mínima $(\sim 0,04 \mathrm{mg} / \mathrm{mL})$, a perda de rfPspA3 também foi pequena, ficando em torno de apenas $0,6 \%$ em todas as frações.

A Figura 4.51 mostra os resultados do teste de adsorção em pH de 5,0 a 6,5 .

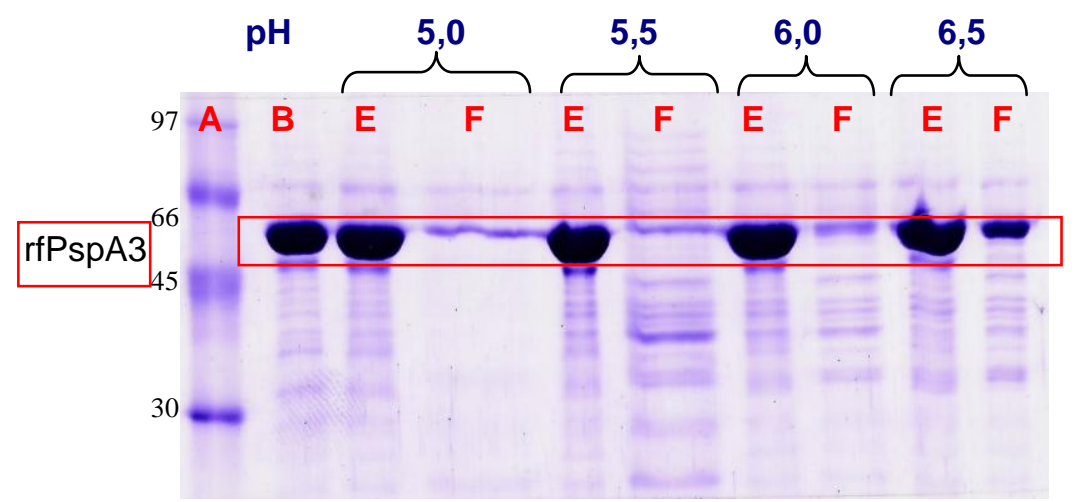

Figura 4.51: Gel de eletroforese do teste de adsorção em tubos com resina SP-Sepharose na faixa de $\mathrm{pH}$ entre 5,0 e 6,5. A-Padrão de massa molecular (kDa); B-Amostra inicial em pH 8,0

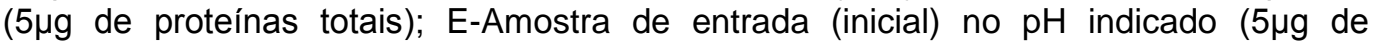
proteínas totais) e F-Fração não adsorvida em resina SP-Sepharose no pH indicado

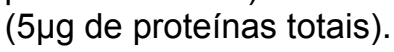

De acordo com a Figura 4.51 houve perda de rfPspA3 na fração não adsorvida em todos os $\mathrm{pH}$. Porém, nos $\mathrm{pH} 5,5$ e 6,0 houve maior retirada de impurezas, pois a pureza relativa de rfPspA3 nestas frações ficou em torno de 16\%, o que significa uma perda de aproximadamente $2 \%$ de rfPspA3 nestas frações. $\mathrm{O} \mathrm{pH}$ 6,0 foi escolhido para trabalho, pois, foi observada precipitação da amostra em $\mathrm{pH}$ 5,5 após um tempo acima de uma hora, o que não havia sido verificado na precipitação isoelétrica (item 4.3.8.3).

Sabe-se que em pH 6,0 o rfPspA3 possui carga total negativa, a mesma carga da resina. Contudo mesmo assim foi possível adsorvê-la nestas condições. Uma explicação para este fato é que apesar de a carga total deste fragmento ser negativa em pH acima de seu pl $(4,74)$, a região "coiled-coil” da proteína possui carga positiva até pH 6,9. De acordo com a análise desta parte da sequência da proteína, correspondente a região enovelada, pelo site da Scripps Researchs 
Institute ${ }^{57}$ constatou-se que em $\mathrm{pH}$ 6,0 o valor da carga teórica dessa região protéica é aproximadamente 4,0 positivo, sendo que o fragmento inteiro possui valor de carga total de 16,8 negativo neste mesmo $\mathrm{pH}$. Este fato foi observado por Jedrzejas et al. $^{12}$, ele mostrou as diferenças de distribuição eletrostática do fragmento recombinante de PspA (Figura 4.52), semelhante ao fragmento deste trabalho.

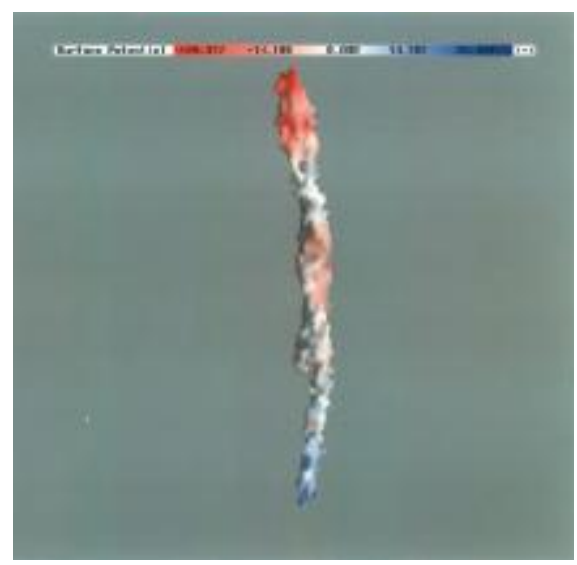

Figura 4.52: Estrutura tridimensional do fragmento protéico da PspA estudado por Jedrzejas et al. ${ }^{12}$. A parte vermelha enovelada corresponde à magnitude da potência eletrostática negativa e a azul, região rica em prolina, positiva.

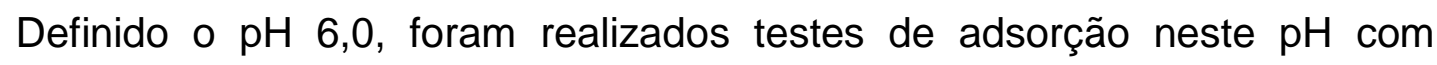
diferentes concentrações de $\mathrm{NaCl}$, de 10 a $100 \mathrm{mM}$. A Figura 4.53 apresenta os resultados deste teste.

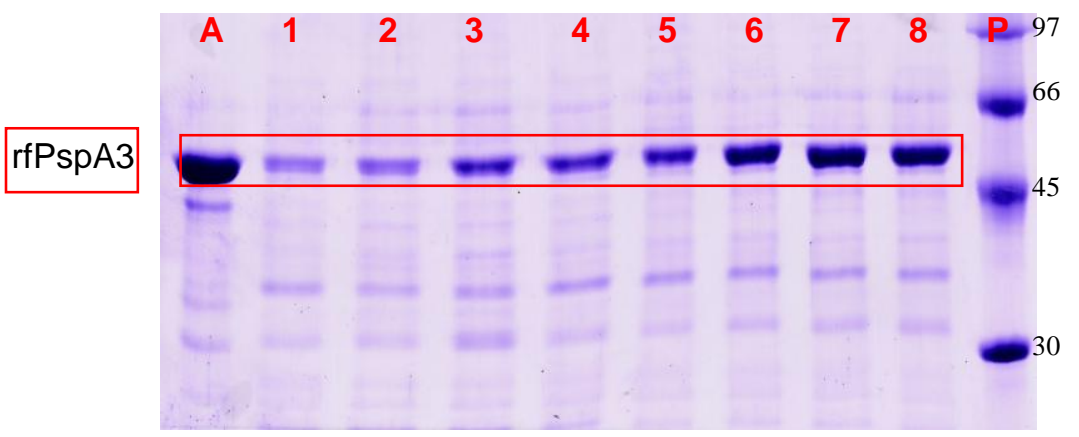

Figura 4.53: Gel de eletroforese do teste de adsorção em tubos à resina SP-Sepharose em diferentes concentrações de $\mathrm{NaCl}$ à $\mathrm{pH}$ 6,0. P-Padrão de massa molecular $(\mathrm{kDa})$; $\mathrm{A}$ Amostra inicial ( $2 \mu \mathrm{g}$ de proteínas totais); 1-8-Frações não-adsorvidas (em todas $2 \mu \mathrm{g}$ de proteínas totais) com: $1-10 \mathrm{mM}$ de $\mathrm{NaCl}$; $2-20 \mathrm{mM}$ de $\mathrm{NaCl}$; $3-30 \mathrm{mM}$ de $\mathrm{NaCl}$; 4 $40 \mathrm{mM}$ de $\mathrm{NaCl} ; 5-50 \mathrm{mM}$ de NaCl$; 6-70 \mathrm{mM}$ de $\mathrm{NaCl} ; 7-90 \mathrm{mM}$ de $\mathrm{NaCl} ; 8-100 \mathrm{mM}$ de $\mathrm{NaCl}$.

Através desta figura, nota-se que um pequeno aumento na força iônica foi suficiente para que o rfPspA3 perdesse sua interação com a resina. Apesar de haver perda, mesmo com $10 \mathrm{mM}$ de $\mathrm{NaCl}(\sim 6,0 \%)$, foi decido realizar a adsorção nesta 
concentração na coluna, pois, há também na fração não adsorvida diversa impurezas, o que justificaria a perda do rfPspA3 caso houvesse ganho em pureza.

- Testes de dessorção em coluna empacotada

Foram realizados os seguintes testes de eluição:

1. por sal em tampão Tris $25 \mathrm{mM} \mathrm{pH} \mathrm{6,0}$

2. por pH em tampão Tris $25 \mathrm{mM} \mathrm{pH} \mathrm{7,0} \mathrm{a} 8,0$

3. por sal e pH em tampão Tris $25 \mathrm{mM} \mathrm{pH} \mathrm{7,0}$

4. a pH 7,0 em tampão fosfato com ou sem $\mathrm{NaCl}$

Para eluição por sal foram empregadas as concentrações de 70, $100 \mathrm{e}$ $150 \mathrm{mM} \mathrm{NaCl}$ e para eluição por pH foi utilizado tampão histidina $20 \mathrm{mM} \mathrm{pH} \mathrm{6,0} \mathrm{com}$ $10 \mathrm{mM}$ de $\mathrm{NaCl}$ para carregar a resina e tampão Tris $25 \mathrm{mM}$ para a eluição. No primeiro teste observou-se que $150 \mathrm{mM}$ de $\mathrm{NaCl}$ não foi suficiente para eluir todo o rfPspA3, uma vez que houve presença desta proteína na fração de limpeza com 500 $\mathrm{mM}$ de $\mathrm{NaCl}$. No segundo teste, conseguiu-se recuperar quase toda proteína em $\mathrm{pH}$ 8,0 , porém ainda houve presença desta na fração de limpeza. Durante este teste foi observado que a entrada da amostra com $10 \mathrm{mM}$ de $\mathrm{NaCl}$ em tampão histidina $20 \mathrm{mM}$ pH 6,0 estava provocando perda de rfPspA3 na fração não adsorvida, por isso decidiu-se equilibrar a coluna com tampão histidina $20 \mathrm{mM}$ sem $\mathrm{NaCl}$, ajustando a amostra para a mesma condutividade do tampão de equilíbrio.

No terceiro teste a eluição foi feita com tampão Tris $25 \mathrm{mM} \mathrm{pH} \mathrm{7,0} \mathrm{na}$ presença de 40,60, 80 e $100 \mathrm{mM}$ de $\mathrm{NaCl}$. Neste teste foi inserida uma etapa de lavagem com o tampão de histidina $20 \mathrm{mM} \mathrm{pH} \mathrm{6,0+10} \mathrm{mM} \mathrm{de} \mathrm{NaCl}$, mesmo tampão utilizado para equilíbrio nos testes anteriores. A Figura 4.54 mostra 0 resultado deste teste. 


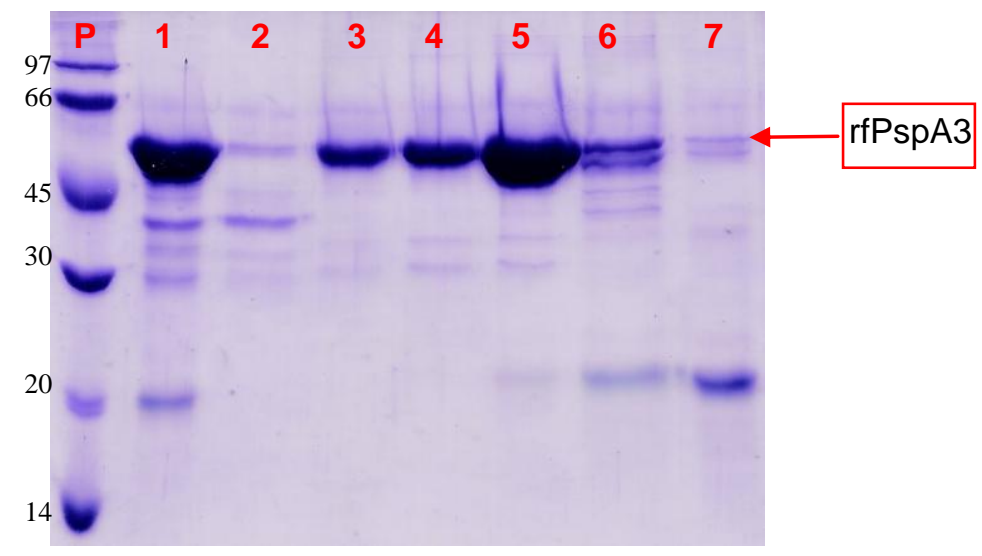

Figura 4.54: Gel de eletroforese do terceiro teste de eluição em coluna empacotada com resina SPSepharose Fast Flow em pH 7,0 com diferentes concentrações de $\mathrm{NaCl}$. P-Padrão de massa molar $(\mathrm{kDa})$; 1-Amostra inicial, eluição da segunda cromatografia: IMACSepharose; 2-Fração não adsorvida; 3-Fração de lavagem em pH 6,0 com $10 \mathrm{mM}$ de $\mathrm{NaCl}$; 4- Fração de eluição em pH 7,0 com $40 \mathrm{mM}$ de NaCl; 5- Fração de eluição em pH 7,0 com $60 \mathrm{mM}$ de $\mathrm{NaCl}$; 6- Fração de eluição em pH 7,0 com $100 \mathrm{mM}$ de $\mathrm{NaCl}$ e 7Fração de limpeza em pH 8,0 com $500 \mathrm{mM}$ de $\mathrm{NaCl}$. Foram adicionados $5 \mu \mathrm{g}$ de proteínas totais de todas as amostras.

Verificou-se na Figura 4.54 que na fração não adsorvida houve eliminação de impurezas, o que não aconteceu na fração de lavagem (caneleta 3 ), onde não houve retirada de impurezas que justificasse a perda de rfPspA3 nesta fração. Observou-se também que a eluição com tampão Tris $25 \mathrm{mM} \mathrm{pH} \mathrm{7,0+60} \mathrm{mM} \mathrm{de}$ $\mathrm{NaCl}$ (caneleta 5) possibilitou a recuperação da proteína sem impurezas, o que não aconteceu na fração com $100 \mathrm{mM}$ de $\mathrm{NaCl}$ (caneleta 6). Assim, o tampão com Tris $25 \mathrm{mM} \mathrm{pH} \mathrm{7,0} \mathrm{+60} \mathrm{mM} \mathrm{de} \mathrm{NaCl} \mathrm{foi} \mathrm{definido} \mathrm{para} \mathrm{eluição} \mathrm{da} \mathrm{SP-Sepharose.} \mathrm{Porém,}$ novas tentativas foram feitas para a troca do tampão Tris $25 \mathrm{mM}$ para fosfato $50 \mathrm{mM}$, pois o tampão Tris utilizado não teve força tamponante suficiente para segurar o $\mathrm{pH}$ em 7,0.

Assim, para o quarto teste as seguintes frações de eluição foram obtidas: tampão fosfato $50 \mathrm{mM} \mathrm{pH} \mathrm{7,0} \mathrm{com} \mathrm{0,15,} 30$ e $40 \mathrm{mM}$ de $\mathrm{NaCl}$. A condutividade do tampão fosfato $50 \mathrm{mM}$ sem $\mathrm{NaCl}$ foi suficiente para recuperar o rfPspA3. Devido a eluição de algumas impurezas junto com o rfPspA3, tentou-se diminuir a concentração de fosfato na tentativa de recuperá-la mais pura. Os valores de tampão fosfato $\mathrm{pH} 7,0$ utilizados foram $50,40,30$ e $20 \mathrm{mM}$. O resultado deste último teste está representado no gel de eletroforese SDS-PAGE da Figura 4.55. 


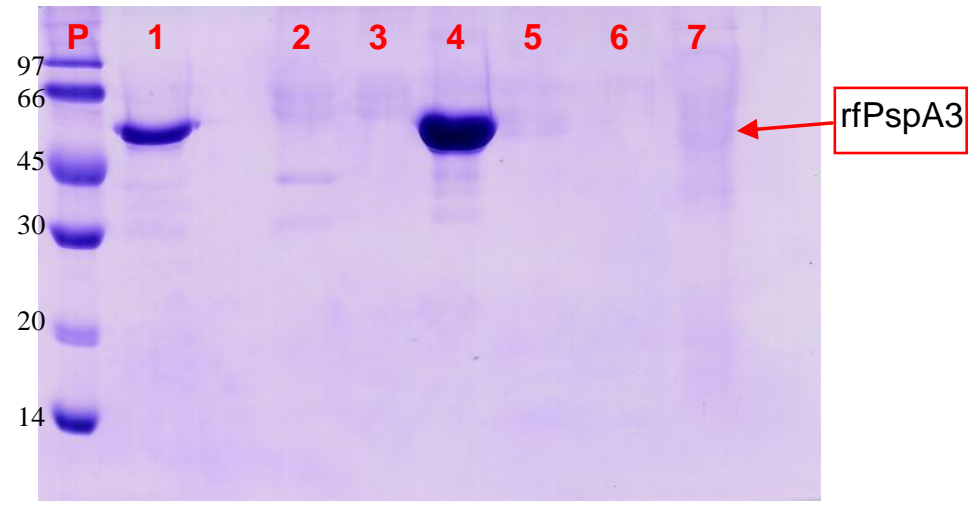

Figura 4.55: Gel de eletroforese do teste de eluição com diferentes concentrações de tampão fosfato pH 7,0 em coluna empacotada com resina SP-Sepharose Fast Flow. P-Padrão de massa molar $(\mathrm{kDa})$; 1-Amostra inicial, eluição da segunda cromatografia: IMACSepharose; 2-Fração não adsorvida; 3-Fração de eluição em pH 7,0 com $20 \mathrm{mM}$ de tampão fosfato; 4- Fração de eluição em pH 7,0 com $30 \mathrm{mM}$ de tampão fosfato; 5Fração de eluição em pH 7,0 com 40 mM de tampão fosfato; 6 - Fração de eluição em pH 7,0 com 50 mM de tampão fosfato e 7-Fração de limpeza em Tris pH 8,0 com 500 $\mathrm{mM}$ de $\mathrm{NaCl}$. Foram adicionados $5 \mu \mathrm{g}$ de proteínas totais de todas as amostras.

De acordo com a Figura 4.55, observou-se que $30 \mathrm{mM}$ de tampão fosfato $\mathrm{pH} 7,0$ foi suficiente para recuperar a maior parte do rfPspA3 nesta etapa (73\%), com uma pureza relativa de $93,5 \%$. Pela densitometria do gel, observou-se a presença de rfPspA3 também nas frações não adsorvida e com $40 \mathrm{mM}$ e $50 \mathrm{mM}$ de fosfato $\mathrm{pH} 7,0$ que somadas representariam $27 \%$ de perdas.

Deste modo, foi definida como terceira etapa cromatográfica a resina de troca catiônica SP-Sepharose, pois entre as 3 resinas propostas para esta etapa, ela foi a que melhor purificou a amostra de rfPspA3. Esta etapa cromatográfica foi definida nas condições apresentadas na Figura 4.56.

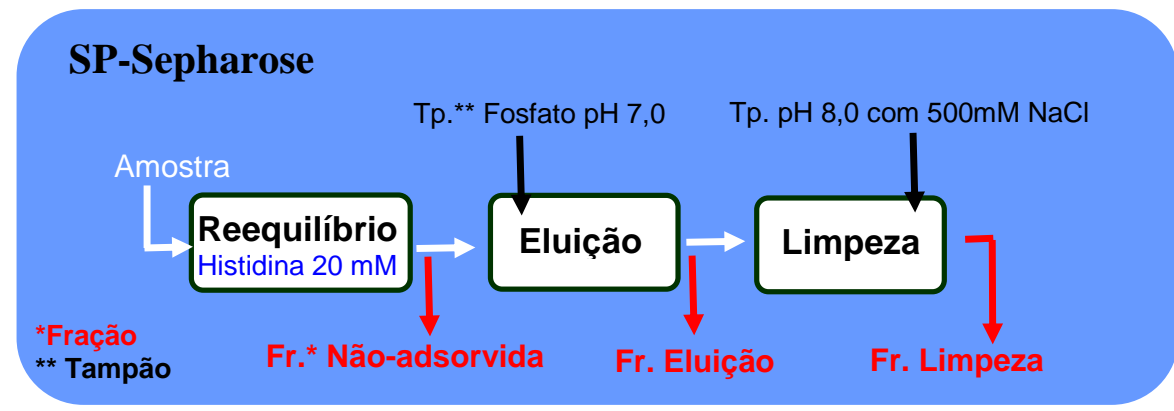

Figura 4.56: Condições da cromatografia em SP-Sepharose Fast-Flow determinada como última etapa cromatográfica da sequência de purificação de rfPspA3. 


\subsection{COMPARAÇÃO ENTRE A PURIFICAÇÃO DO rfPspA3 OBTIDO EM CULTIVOS DE ALTA DENSIDADE COM GLICOSE E COM GLICEROL}

A Figura 4.57 apresenta a sequência de cromatografias definida para a purificação do rfPspA3.

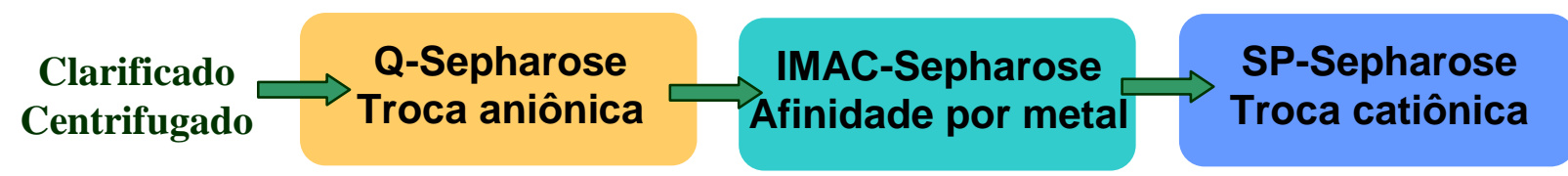

Figura 4.57: Fluxograma das etapas cromatográficas definidas para purificação de rfPspA3.

Uma vez definidas as condições de cada cromatografia, todo o processo de purificação foi realizado com amostras oriundas dos cultivos em alta densidade com glicose e com glicerol como fonte de carbono.

Para a purificação a partir do cultivo com glicose foi utilizada a fração de eluição da IMAC-Sepharose como segunda cromatografia, obtida como descrito no item 4.3.7.3 (Tabela 4.12). A amostra foi dialisada por 24 horas e histidina $1 \mathrm{M}$ foi empregada para ajustar o pH para 6,0 e a condutividade após diálise, de acordo com o tampão de equilíbrio da SP-Sepharose (histidina $20 \mathrm{mM} \mathrm{pH} \mathrm{6,0).}$

Com o clarificado do cultivo com glicerol foi realizada a cromatografia em QSepharose nas mesmas condições empregadas para o material proveniente do cultivo com glicose. Com a definição da SP-Sepharose como última etapa cromatográfica e, como esta necessita de baixa condutividade na adsorção, foi realizada a eluição da segunda cromatografia em IMAC-Sepharose sem adição de $\mathrm{NaCl}$ a fim de evitar a etapa adicional de diálise. Para diminuir a condutividade da fração de eluição com imidazol $200 \mathrm{mM}$ sem sal, foi inserida uma nova etapa com 1

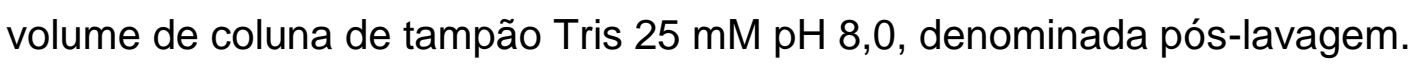

A Figura 4.58 mostra as etapas de purificação realizadas e as condições nas quais foram feitas a partir da lise celular. 

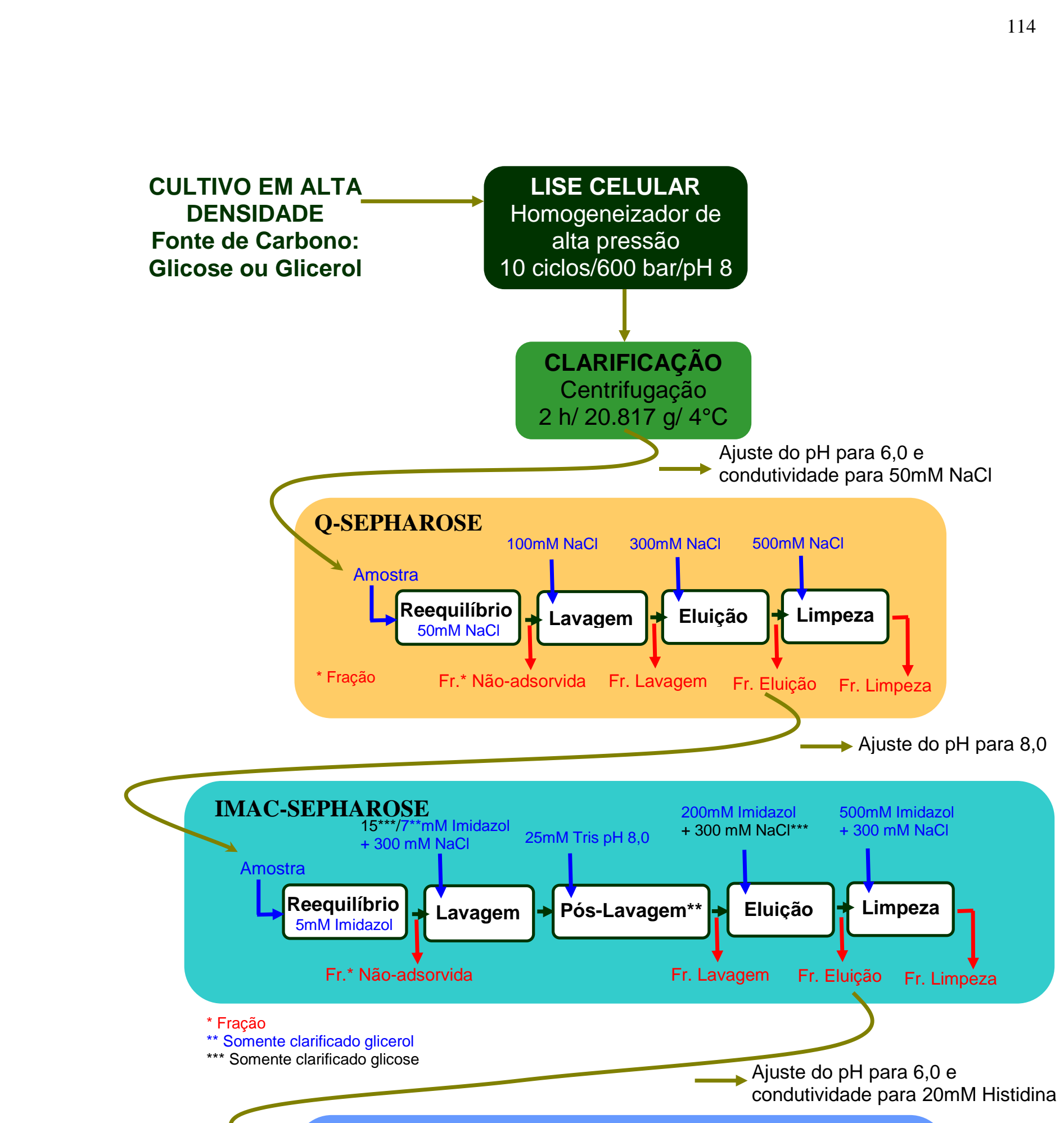

SP-SEPHAROSE Tp.* Fosfato $30 \mathrm{mM}$

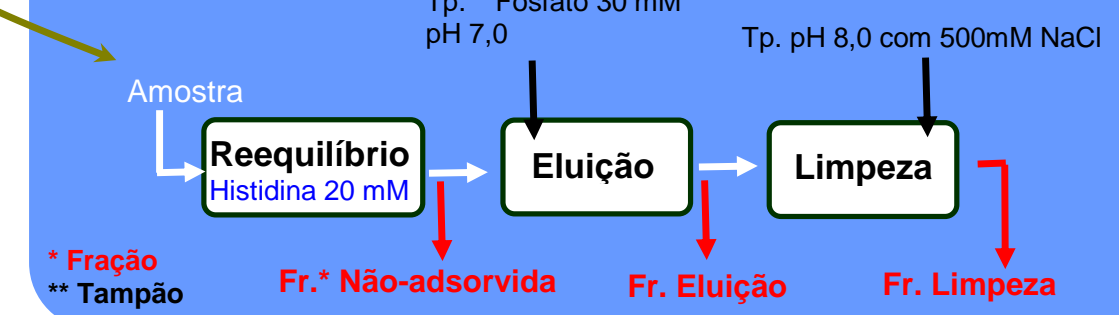

Figura 4.58: Fluxograma das etapas de purificação realizadas e suas respectivas condições de eluição para purificação do rfPspA3. 
As Figuras 4.59 a 4.61 apresentam as eletroforeses SDS-PAGE das frações obtidas das etapas cromatográficas mostradas na Figura 4.58.

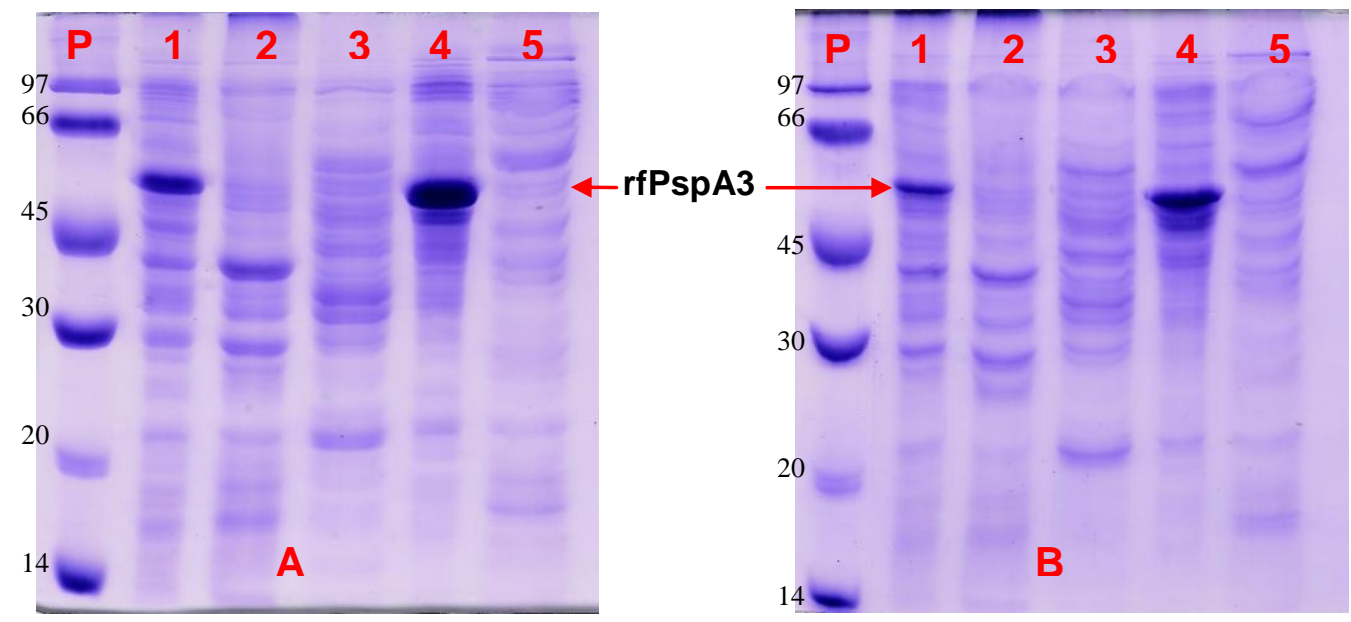

Figura 4.59: Géis de eletroforese SDS-PAGE da primeira cromatografia Q-Sepharose utilizando o clarificado obtido do cultivo com glicose como fonte de carbono (A) e glicerol (B). PPadrão de massa molecular (kDa); 1-Amostra inicial, clarificado centrifugado; 2-Fração não adsorvida; 3-Fração de lavagem com $100 \mathrm{mM}$ de $\mathrm{NaCl}$; 4-Fração de eluição com $300 \mathrm{mM}$ de $\mathrm{NaCl}$ e 5-Fração de limpeza com $500 \mathrm{mM}$ de NaCl. Foram adicionados 10 $\mu \mathrm{g}$ de proteínas totais de todas as amostras com exceção das frações de eluição $(5 \mu \mathrm{g})$.

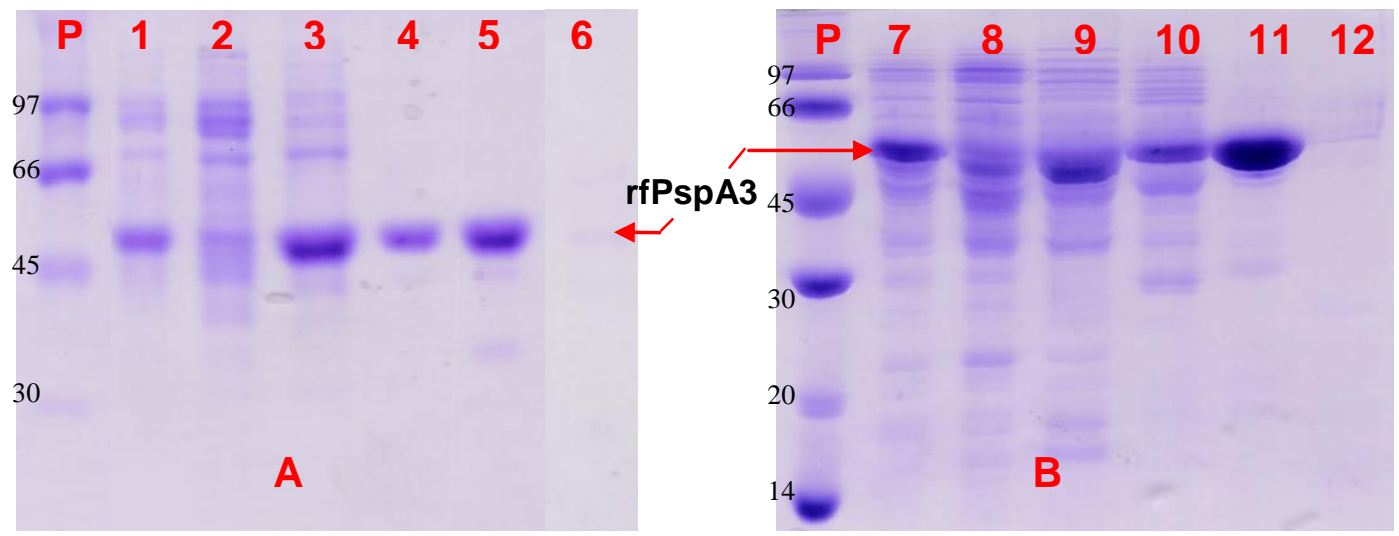

Figura 4.60: Géis de eletroforese SDS-PAGE da segunda cromatografia IMAC-Sepharose utilizando - clarificado obtido do cultivo com glicose (A) e glicerol (B). P-Padrão de massa molecular (kDa); 1-Amostra inicial, eluição da Q-Sepharose; 2-Fração não adsorvida; 3Fração de lavagem com $15 \mathrm{mM}$ de Imidazol; 4-Fração de eluição do primeiro pico com 200 mM de Imidazol; 5- Fração de eluição do segundo pico com 200 mM de Imidazol; 6Fração de limpeza com 500 mM de imidazol; 7-Amostra inicial, eluição da Q-Sepharose; 8-Fração não adsorvida; 9-Fração de lavagem com $7 \mathrm{mM}$ de Imidazol 10-Fração da pós-lavagem com tampão Tris $25 \mathrm{mM}$ pH 8,0; 11- Fração de eluição com $200 \mathrm{mM}$ de Imidazol e 12-Fração de limpeza com $500 \mathrm{mM}$ de imidazol. Foram adicionados $10 \mu \mathrm{g}$ de proteínas totais de todas as amostras com exceção das frações de eluição e póslavagem $(5 \mu \mathrm{g})$. 


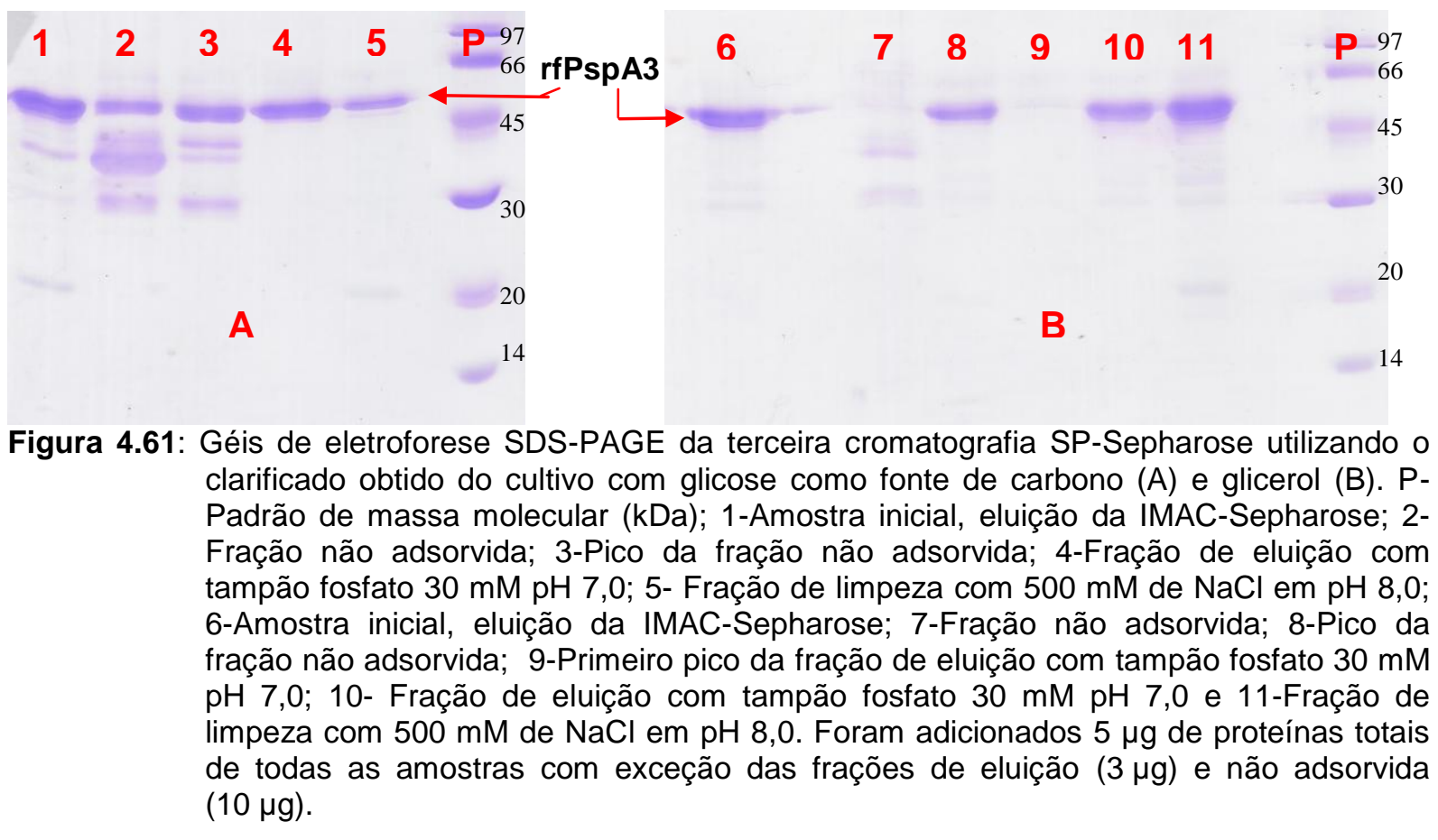

De acordo com as figuras, observa-se que na primeira cromatografia em QSepharose (Figura 4.59) obteve-se purificação semelhante para os dois clarificados, retirando os mesmos contaminantes e apresentando o mesmo perfil, apesar da enorme quantidade de proteínas nas frações. Na segunda cromatografia (IMACSepharose, Figura 4.60) houve também certa semelhança no perfil das eletroforeses. Com a purificação a partir do cultivo com glicose como fonte de carbono foram obtidas duas frações na eluição. Verifica-se que na segunda fração de eluição (Figura 4.60A - caneleta 5) foram encontradas poucas impurezas de peso molecular menor que o rfPspA3, estas mesmas impurezas foram notadas também na fração de eluição da purificação de IMAC-Sepharose a partir do cultivo com glicerol (Figura 4.60B - caneleta 11). Durante a etapa de pós-lavagem, um pico foi eluído no momento exato de queda da condutividade. Esse pico foi coletado separadamente para análise (Figura 4.60B - caneleta 9). Verificou-se a presença de rfPspA3 nesta fração, porém houve retirada de muitos contaminantes, como mostra a figura.

Na Figura 4.61 A e B estão apresentadas as eletroforeses das frações da última etapa cromatográfica SP-Sepharose. Durante o final da coleta das frações não adsorvidas observou-se a formação de um pico com as duas amostras. Esta fração foi coletada separadamente para análise em eletroforese (caneletas 3 e 8). Observou-se que, apesar da forte presença de rfPspA3, impurezas também foram 
eluídas nesta fração. Observou-se também que a presença desta proteína na fração não adsorvida (caneletas 2 e 7) foi mais intensa na purificação da amostra proveniente do cultivo de glicose que do cultivo de glicerol, porém o contrário acontece na fração de limpeza (caneletas 5 da Figura 4.61A e 11 da Figura 4.61B). Nestas figuras pode-se verificar a presença de rfPspA3 em quase todas as frações, indicando perda da proteína de interesse. Este fato pode ser explicado devido à presença de duas regiões de cargas opostas no rfPspA3 (Figura 4.52), dificultando a interação entre a proteína e a resina em pH 6,0 e a eluição em pH 7,0. As perdas verificadas nesta cromatografia foram necessárias para separar as impurezas presentes na amostra inicial do rfPspA3. Os dados de pureza relativa foram calculados através do HPSEC. As Figuras 4.62 e 4.63 apresentam os cromatogramas das purificações provenientes das amostras dos cultivos de glicose e glicerol, respectivamente e as Tabelas 4.15 e 4.16 mostram os resultados dos fatores de purificação.

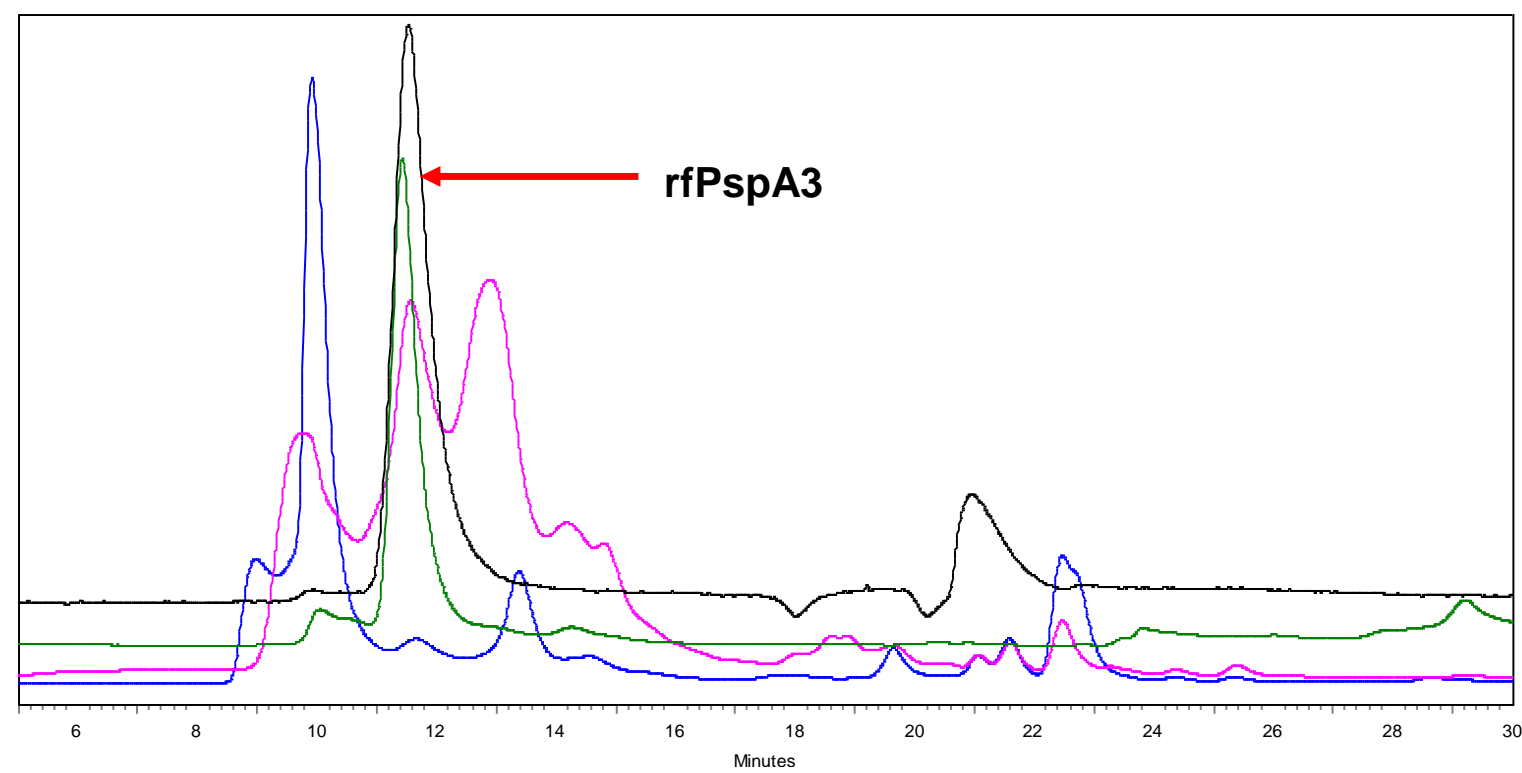

Figura 4.62: Cromatogramas do clarificado centrifugado e frações de eluição das etapas cromatográficas de purificação da amostra proveniente do cultivo em alta densidade com glicose como fonte de carbono. Cromatogramas em escala arbitrária: azulHomogenato Clarificado, rosa-eluição Q, verde-pool da eluição IMAC, preto-eluição $\mathrm{SP}$, tempo de retenção da rfPspA3 = 11-12min. 
Tabela 4.15: Tabela de purificação da amostra proveniente do cultivo em alta densidade com glicose como fonte de carbono.

\begin{tabular}{|c|c|c|c|c|c|}
\hline & $\begin{array}{c}\text { Proteínas } \\
\text { Totais }(\mathrm{mg})\end{array}$ & $\begin{array}{c}\text { P. R. } \\
\text { rfPspA3 (\%) }\end{array}$ & $\begin{array}{c}\text { rfPspA3 } \\
\text { (mg) }\end{array}$ & $\begin{array}{l}\text { Recuperação } \\
\text { de rfPspA3 (\%) }\end{array}$ & $\begin{array}{c}\text { Fator de } \\
\text { Purificação }\end{array}$ \\
\hline Clarificado Centrifugado & 12771 & 6,26 & $1240,4^{\star \star}$ & 100 & 1,0 \\
\hline Q-Sepharose & 3963 & 28,61 & 1133 & 91,4 & 4,6 \\
\hline IMAC-Sepharose & 1068 & 81,06 & 867 & $69,9(76,5)^{*}$ & $12,9(2,8)^{*}$ \\
\hline SP-Sepharose & $270,2^{* * *}$ & 65,0 & 175,6 & $34,5(49,4)^{*}$ & $10,4(0,8)^{*}$ \\
\hline
\end{tabular}

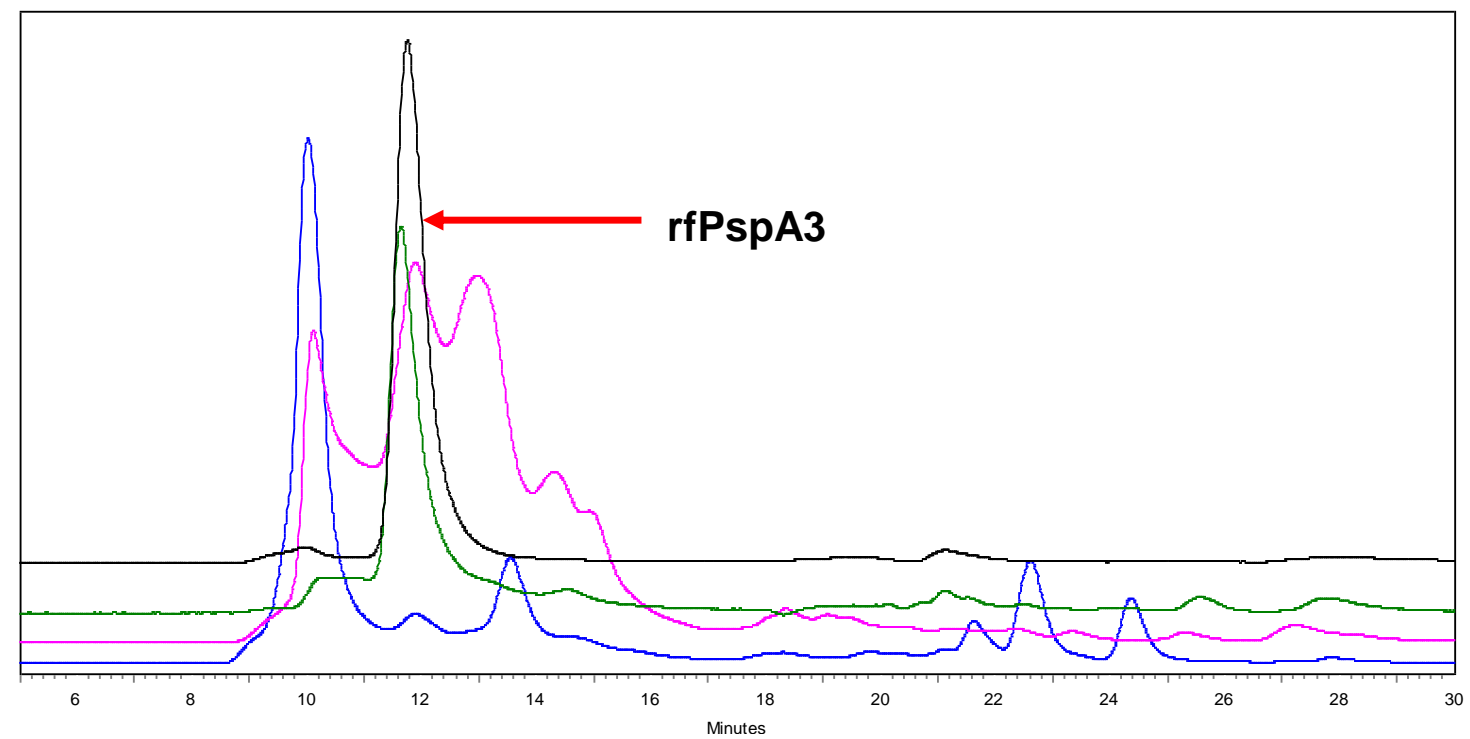

Figura 4.63: Cromatogramas do clarificado centrifugado e frações de eluição das etapas cromatográficas de purificação da amostra proveniente do cultivo em alta densidade com glicerol como fonte de carbono. Cromatogramas em escala arbitrária: azulHomogenato Clarificado, rosa-eluição Q, verde-pool da eluição IMAC, preto-eluição $\mathrm{SP}$, tempo de retenção da rfPspA3 = 11-12min. 
Tabela 4.16: Tabela de purificação da amostra proveniente do cultivo em alta densidade com glicerol como fonte de carbono.

\begin{tabular}{lccccc}
\hline & $\begin{array}{c}\text { Proteínas } \\
\text { Totais }(\mathbf{m g})\end{array}$ & $\begin{array}{c}\text { P. } \mathbf{R}^{{ }^{\top}} \\
\text { rfPspA3 }(\%)\end{array}$ & $\begin{array}{c}\text { rfPspA3 } \\
(\mathbf{m g})\end{array}$ & $\begin{array}{c}\text { Recuperação } \\
\text { de rfPspA3 (\%) }\end{array}$ & $\begin{array}{c}\text { Fator de } \\
\text { Purificação }\end{array}$ \\
\hline Clarificado Centrifugado & 15476 & 6,5 & $1234,8^{* *}$ & 100 & 1,0 \\
Q-Sepharose & 4939,6 & 25,0 & 1234,8 & $100^{* *}$ & 3,8 \\
IMAC-Sepharose & 1342 & 66,4 & 891,1 & 72,2 & $10,2(2,7)^{*}$ \\
SP-Sepharose & 387 & 90,6 & 350,7 & $28,4(39,4)^{*}$ & $13,9(1,4)^{*}$ \\
\hline
\end{tabular}

'Pureza Relativa obtida por HPSEC

*Valores entre parênteses referem-se à recuperação e ao fator de purificação da etapa e fora, do processo todo.

${ }^{* *} \mathrm{O}$ valor da primeira cromatografia foi considerado $100 \%$ devido ao fato de a concentração de rfPspA3 nessa amostra estar subestimada.

De acordo com os resultados obtidos verificou-se que houve perda elevada de rfPspA3 na última cromatografia realizada em SP-Sepharose com as duas amostras utilizadas. Este fato pode ser verificado nas eletroforeses da Figura $4.61 \mathrm{~A}$ e $B$ e também nas Tabelas 4.15 e 4.16. Esta etapa cromatográfica não reproduziu o teste de adsorção realizado anteriormente (Figura 4.55). Com estes resultados não se pode descartar o uso desta cromatografia, mas novos testes mostram-se necessários para melhorar a recuperação do rfPspA3.

Observou-se também que os resultados da cromatografia em Q-Sepharose foram semelhantes, não demonstrando interferência da fonte de carbono usada no cultivo sobre a purificação. Na cromatografia em IMAC-Sepharose, o fator de purificação foi menor para o material proveniente do cultivo com glicerol, provavelmente porque uma concentração menor de imidazol foi empregada na etapa de lavagem (7 mM contra $15 \mathrm{mM}$ para o material do cultivo com glicose). Na terceira cromatografia realizada, SP-Sepharose, utilizando a amostra provinda do cultivo com glicose como fonte de carbono, a pureza relativa do rfPspA3 foi reduzida drasticamente para $65,0 \%$. A redução da pureza relativa foi devido ao aparecimento de um pico com tempo de retenção de 21 min na análise por HPSEC (Figura 4.62 linha preta). Este pico não foi verificado na eluição da IMAC-Sepharose (Figura 4.62, linha verde), o que poderia representar degradação do rfPspA3. Um pico com o mesmo tempo de retenção, porém com menor área, também foi verificado com na amostra purificada do cultivo com glicerol (Figura 4.63 - linha preta).

Ao analisar a fração de eluição da SP-Sepharose por HPSEC sem levar em consideração a área do pico de $\sim 21 \mathrm{~min}$, o valor da pureza relativa chega a 90,1\%, obtendo-se uma recuperação de $48 \%$ do rfPspA3 a partir do cultivo com glicose. Ao 
analisar as frações de eluição dos géis de eletroforese SDS-PAGE da Figura 4.61 por densitometria os seguintes valores de pureza relativa foram obtidos: 93,4 e $86,9 \%$ das amostras provindas dos cultivos com glicose e glicerol como fonte de carbono, respectivamente.

Diferentes concentrações da fração de eluição da SP-Sepharose da amostra provinda do cultivo com glicerol foram aplicadas a um gel de eletroforese SDS-PAGE (Figura 4.64) e a pureza relativa dessas amostras foi analisada por densitometria (Tabela 4.17).

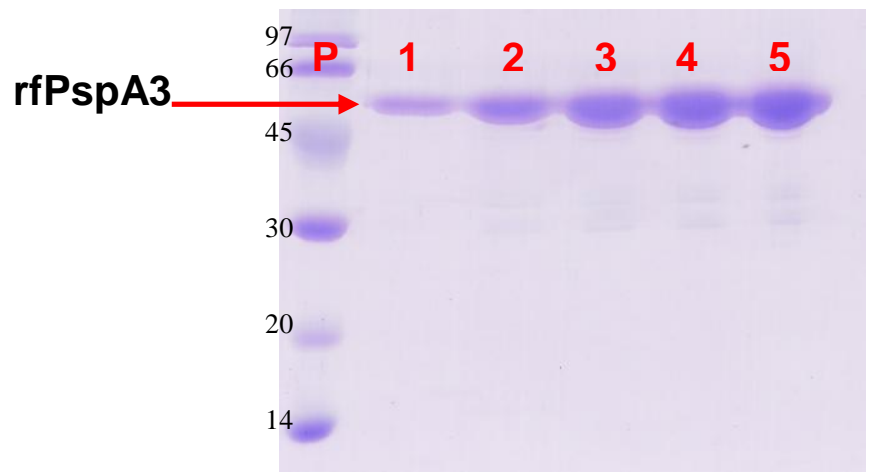

Figura 4.64: Gel de eletroforese SDS-PAGE da fração de eluição da SP-Sepharose Fast Flow obtida da produção com glicerol como fonte de carbono em diferentes quantidades de proteínas totais. P-Padrão de massa molecular $(\mathrm{kDa}) ; 1$ - $1 \mu \mathrm{g}$ de proteínas totais; $2-2 \mu \mathrm{g}$ de proteínas totais; 3- $3 \mu \mathrm{g}$ de proteínas totais; 4 - $4 \mu \mathrm{g}$ de proteínas totais e 5 - $5 \mu \mathrm{g}$ de proteínas totais.

Tabela 4.17: Pureza relativa do rfPspA3 purificado a partir do cultivo com glicerol.

\begin{tabular}{cc}
\hline Proteínas Totais $(\boldsymbol{\mu g})$ & Pureza relativa de $\mathbf{r f P s p A 3}(\%)$ \\
\hline 1 & 93,7 \\
2 & 93,0 \\
3 & 91,4 \\
4 & 93,2 \\
5 & 90,6 \\
\hline
\end{tabular}

De acordo com os resultados obtidos observou-se que a pureza relativa diminuiu à medida que aumentou a quantidade de proteínas totais aplicadas ao gel, como já era esperado. A pureza requerida para uma proteína recombinante em $E$. coli é de $95 \%$, o que não foi alcançado por este trabalho. Entretanto, a densidade da banda de rfPspA3 obtida com $1 \mu \mathrm{g}$ de proteína total estava próxima ao limite de detecção do equipamento, portanto $\circ$ valor de pureza relativa poderia estar subestimado acima de $2 \mu \mathrm{g}$. 


\subsection{ANÁLISE ESTRUTURAL DO rfPspA3 PURIFICADO}

A amostra de rfPspA3 da fração de eluição da cromatografia SP-Sepharose proveniente do cultivo com glicerol foi analisada por dicroísmo circular (CD) . Esta fração foi escolhida por estar em maior concentração e pureza. A obtenção do espectro foi realizada na faixa de $185-280 \mathrm{~nm}$ em temperatura ambiente $\left(\sim 25{ }^{\circ} \mathrm{C}\right)$, com uma solução protéica de $0,33 \mathrm{mg} / \mathrm{mL}$, o que corresponde a $\sim 8,5 \mu \mathrm{M}$. O resultado está apresentado na Figura 4.65.

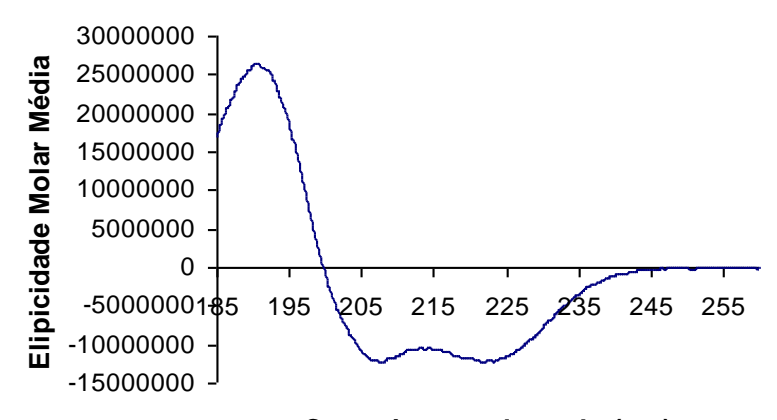

Comprimento de onda $(\mathrm{nm})$

Figura 4.65: Espectro CD do rfPspA3 purificado a partir do cultivo com glicerol.

De acordo com a Figura 4.65, o rfPspA3 purificado possui estrutura secundária $\alpha$-helicoidal sem presença de $\beta$-sheet ${ }^{42}$. Jedrzejas et al. ${ }^{12}$ estudando diversas construções de PspA encontrou em uma destas construções (Rx1314Ml) o mesmo perfil de espectro de CD encontrado neste trabalho como mostra a Figura 4.66.

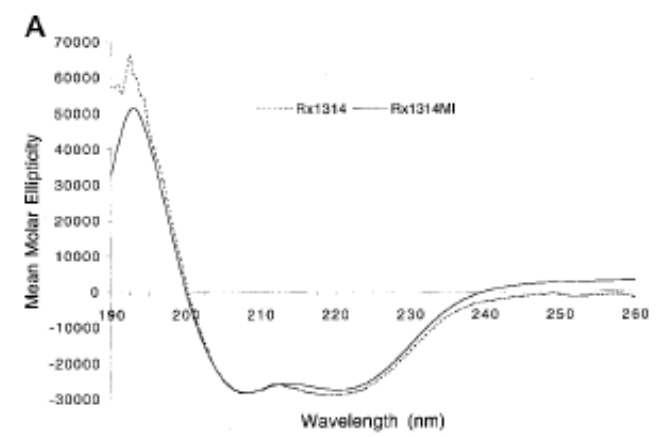

Figura 4.66: Espectro de CD obtido nas construções de PspA Rx1314 (----) e Rx1314MI $(-)$ segundo Jedrzejas et al. ${ }^{12}$.

Segundo este autor, esse perfil refere-se a uma estrutura $\alpha$-helicoidal tendo uma conformação "coiled-coil" como mostra a Figura 4.52. Assim, devido a similaridade entre os cromatogramas confirma-se a estrutura do rfPspA3 deste trabalho. 


\subsection{PONTOS IMPORTANTES DURANTE O PROCESSO DE PURIFICAÇÃO}

\subsubsection{Em relação à manipulação do rfPspA3}

Durante o processo de purificação do rfPspA3 cuidados devem ser tomados a fim de evitar, principalmente, sua precipitação. Como constatado nos testes utilizando diferentes $\mathrm{pH}, \mathrm{pH}$ abaixo de 6,0 favorece sua precipitação, assim, a exposição dessa proteína em $\mathrm{pH}$ baixo deve ser evitada. Foi observado também que, mesmo em pH 6,0, a precipitação desta proteína pode ocorrer quando esta permanece um tempo longo neste $\mathrm{pH}$. Assim, etapas que exigem o ajuste de $\mathrm{pH}$ para 6,0 devem ser realizadas rapidamente. O exposição dessa proteína a pH 6,0 parece também favorecer a agregação de proteínas, este fato foi observado durante as primeiras etapas de purificação. Além disso, segundo González et al. ${ }^{58}$, a presença do detergente Triton X-100 favorece a agregação de proteínas com alta expressão com proteínas da parede celular lisada da bactéria.

Outro fator que favorece a precipitação de rfPspA3 é o congelamento da amostra. Ao estocar algumas frações purificadas dessa proteína em tampão Tris 25 $\mathrm{mM} \mathrm{pH} \mathrm{8,0} \mathrm{à}-20^{\circ} \mathrm{C}$ verificou-se que houve precipitação de grande parte do rfPspA3 ao descongelar a amostra.

\subsubsection{Em relação aos aspectos econômicos do processo}

Em processos onde se visa a ampliação de escala um ponto importante deve ser considerado: a integração dos processos de produção e purificação (up e downstream $)^{59}$. Devido à enorme possibilidade de estratégias de purificação, a sequência das etapas escolhidas é importante, pois ela influencia no tempo exigido para o processo, o que também vai ser refletido no custo. Minimizar custos é importante principalmente na etapa de purificação que normalmente corresponde a mais de $70 \%$ do custo do processo.

$\mathrm{Na}$ etapa de clarificação foi observado que mesmo a filtração tangencial sendo uma opção mais barata, a perda do produto de interesse ( 30\%) foi muito alta para a primeira etapa do processo. Apesar de a centrífuga ser um equipamento caro, há pouca manutenção, não provocou perdas do produto de interesse, tem um 
tempo longo de vida (enquanto que a fibra-oca deve ser trocada regularmente), além de o seu manuseio ser simples.

Algumas escolhas feitas para o processo de purificação do ifPspA3 foram importantes para redução do custo do processo, como no caso do uso da IMACSepharose como segunda cromatografia. Durante os trabalhos foi observado que a resina da primeira etapa cromatográfica tem seu tempo de vida reduzido devido à quantidade de subprodutos presentes no material de partida, assim, o emprego da Q-Sepharose como primeira etapa cromatográfica reduziria o custo total do processo de purificação, uma vez que seu valor é bem mais baixo que o da IMAC-Sepharose, em torno de $72 \%$ mais barata ${ }^{60}$.

Para a terceira etapa cromatográfica, o uso da SP-Sepharose também foi conveniente, pois, empregou-se baixa concentração de sal na eluição e a proteína foi obtida em pH neutro e sem necessitar de ajustes para a realização das etapas de conjugação que se seguirão para elaboração da vacina. Além disso, esta é uma resina relativamente barata, o mesmo valor que a Q-Sepharose e em torno de 30\% mais barata que a Phenyl-Sepharose High Sub Fast Flow e que a Sephacryl S-200 $\mathrm{HR}^{60}$. 


\section{Conclusões}

A inserção do fragmento do gene $p s p A 3$ no plasmídeo $\mathrm{pET} 37 \mathrm{~b}^{+}$gerou uma construção estável em $E$. coli BL21(DE3), pois $>88 \%$ das colônias apresentaram-se resistentes à kanamicina durante os cultivos em frascos agitados, descontínuos e em alta densidade. Houve produção protéica considerável, chegando a $3,4 \mathrm{~g} / \mathrm{L}$, e sem que houvesse escape do rfPspA3 antes da adição do indutor nos cultivos utilizando glicose como fonte de carbono.

Os cultivos em alta densidade proporcionaram produtividade celular 3,0 vezes maiores do que o cultivo descontínuo com glicose como fonte de carbono e 2,5 vezes do que o cultivo com glicerol, alcançando produção volumétrica de $\sim 62 \mathrm{~g} / \mathrm{L}$ de massa seca $\left(\mathrm{DO}_{600 \mathrm{~nm}} \sim 148\right)$ em ambos os cultivos.

Nos cultivos descontínuos, ao utilizar glicose como fonte de carbono, foi obtida produção volumétrica de rfPspA3 35\% maior que ao utilizar glicerol $(0,72 \mathrm{~g} / \mathrm{L}$ contra $0,47 \mathrm{~g} / \mathrm{L}$, respectivamente). Nos cultivos descontínuos alimentados a produção volumétrica com glicose foi $12,0 \%$ maior que com glicerol, atingindo, respectivamente, $3,4 \mathrm{~g} / \mathrm{L}$ e 3,0 $\mathrm{g} / \mathrm{L}$ de rfPspA3.

A produtividade de rfPspA3 no cultivo em alta densidade foi 2,4 vezes maior que no cultivo descontínuo com glicose, aumentando de 0,05 g/L.h para 0,12 g/L.h. Para os cultivos com glicerol, a produtividade aumentou 3,0 vezes, passando de 0,03 g/L.h no cultivo descontínuo para $0,09 \mathrm{~g} / \mathrm{L}$.h no cultivo em alta densidade.

O fragmento recombinante da PspA3 apresentou alta solubilidade em tampão Tris $25 \mathrm{mM} \mathrm{pH} \mathrm{8,0,} \mathrm{mas} \mathrm{precipitou} \mathrm{à} \mathrm{medida} \mathrm{em} \mathrm{que} \mathrm{o} \mathrm{pH} \mathrm{se} \mathrm{aproximou} \mathrm{de}$ seu pl teórico $(4,74)$, o que dificultou o desenvolvimento de etapas de purificação que exigissem $\mathrm{pH}$ abaixo de 5,5.

A análise da lise celular demonstrou que 10 minutos de lise (10 ciclos) em homogeneizador contínuo de alta pressão foi suficiente para obter o máximo de lise celular. Com seis minutos observou-se o início do patamar para a lise do material proveniente do cultivo de alta densidade com glicose. Para a lise do material obtido com glicerol, o patamar foi atingido em sete minutos. Foi obtida 96,7 e $92,7 \%$ de eficiência para as lises do cultivo com glicose e glicerol, respectivamente. A amostra inicial da lise do cultivo com glicerol apresentou o dobro de células que a amostra do cultivo com glicose, indicando que o glicerol teve a função de crioprotetor durante $o$ 
congelamento. A concentração de proteínas totais obtida durante o processo de lise foi semelhante para as duas amostras, confirmando a hipótese anterior. Conclui-se também por este trabalho que é possível acompanhar resultados da lise celular mecânica por técnicas simples como as utilizadas neste trabalho.

$\mathrm{Na}$ etapa de clarificação uma maior retirada de impurezas foi obtida ao utilizar micro/ultrafiltração tangencial em fibra-oca em lugar da centrifugação, porém, a perda de rfPspA3 no material retido foi muito alta e, além disso, o volume de amostra foi diluído cerca de 3 vezes. Assim, apesar da centrifugação não ter se mostrado capaz de remover quantidade expressiva de impurezas do homogenato, não promoveu a diluição e não ocasionou perdas da proteína de interesse.

Nas etapas cromatográficas, a sequência com Q-Sepharose seguida da IMAC-Sepharose apresentou melhor rendimento e maior pureza relativa do rfPspA3 (69,9\% e 81,06\%, respectivamente) em relação à sequência inversa $(49,1 \%$ e $75,8 \%$, respectivamente), consequentemente, maior fator de purificação, chegando à 12,9 na primeira sequência contra 10,1 na segunda. Além disso, a resina QSepharose como primeira etapa reduziria também o custo total do processo.

Para a terceira etapa de purificação, necessária para chegar-se à pureza requerida, a cromatografia de troca catiônica utilizando a resina SP-Sepharose demonstrou ser a mais indicada pelos testes prévios realizados. Porém, durante a purificação o processo não foi reprodutível, ocasionando perdas elevadas de rfPspA3 $(\sim 30 \%)$ e baixa recuperação desta proteína ( 30\%), indicando ser necessário o refinamento desta última etapa para evitar estas perdas.

De acordo com os resultados da primeira etapa de purificação (Q-Sepharose) realizada utilizando amostras obtidas do cultivo com glicose e com glicerol como fontes de carbono, houve semelhança nos parâmetros de purificação, indicando que não houve interferência direta do processo de produção (cultivo) nesta etapa.

Por fim, este trabalho contribuiu em vários aspectos da produção e purificação do rfPspA3, pois definiu estratégias de produção em cultivo de alta densidade, determinou condições de purificação e estabeleceu a sequência das etapas cromatográficas. Deste modo, caso novas construções dessa proteína fossem feitas sem cauda de histidina, poderíamos empregar como ponto de partida as diversas cromatografias estudadas para realizar a purificação do fragmento de PspA3 sem o uso da resina de afinidade por metal. 


\section{REFERÊNCIAS BIBLIOGRÁFICAS*}

1 KAMERLING J. P. Pneumococcal polysaccharides: a chemical view. In: TOMASZ, A. (Ed.). Streptococcus pneumoniae Molecular Biology and Mechanisms of Disease. New York: Mary Ann Liebert Publishers Inc., p. 81-114, 2000.

2 PNEUMOADIP. Diseases \& Vaccines. Disponível em: <http://www.preventpneumo.org/diseases/>. Acesso em: 25 fev. 2009.

3 ORGANIZACIÓN PAN-AMERICANA DE LA SALUD. Informe Regional de Sireva II. Datos por país y por grupos de edad sobre las características de los aislamientos de Streptococcus pneumoniae, Haemophilus influenzae y Neisseria meningitidis, en procesos invasores, 2000-2005. Washington, D.C.: OPS, 2007. (Documentos Técnicos. Tecnologías Esenciales de Salud. THS/EV2007/002).

4 VELASCO, E. A.; VERHEUL, A. F. M.; VERHOEL, J.; SNIPPE, H. Streptcoccus pneumoniae: Virulence Factors, Pathogenesis, and Vaccines. Microbiological Reviews, v. 59, p. 591-503, 1995.

5 BRILES, D. E.; HOLLINSHEAD S.; NABORS G. S.; PATON J. C.; BROOKSWALTER A. The potential for using protein vaccines to protect against otitis media caused by Streptococcus pneumoniae. Vaccine, v.19, p. S87-S95, 2001.

6 BRILES, D. E.; HOLLINSHEAD S.; SWIATLO E.; BROOKS-WALTER A.; SZALAI A.; VIROLAINEN A.; MCDANIEL L. S.; BENTON K.; White, P.; Prellner, K.; Hermansson, A.; AERTS P. C.; DIJK H. V.; CRAIN M. J. PspA and PspC: Their potential for use as pneumococcal vaccines. Microbial Drug Resistance, v. 3, n.4, p. 401-408, 1997.

7 BRILES, D. E.; HOLLINSHEAD S.; BROOKS-WALTER A.; NABORS G. S.; FERGUSON L.; SCHILLING M.; GRAVENSTEIN S.; BRAUN P.; KING J.; SWIFT A. The potential to use PspA and other pneumococcal proteins to elicit protection against pneumococcal infection. Vaccine, v. 18, p. 1707-1711, 2000.

8 BRILES, D. E.; TART, R. C.; SWIATLO, E.; DILLARD, J. P.; SMITH, P.; BENTON, K. A.; RALPH, B. A.; BROOKS-WALTER, A.; CRAIN, M. J.; HOLLINGSHEAD, S. K., MCDANIEL, L. S. Pneumococcal diversity: considerations for new vaccine strategies with emphasis on Pneumococcal surface protein A (PspA). Clinical Microbiology Rewiews, v. 11, p. 645-657, 1998.

\footnotetext{
* De acordo com:

ASSOCIAÇÃO BRASILEIRA DE NORMAS TÉCNICAS. NBR 6023: Informação e documentação: referências: elaboração. Rio de Janeiro, 2002.
} 
9 YOTHER, J.; LEOPOLD, K.; WHITE, J.; FISCHER, W. Generation and properties of a Streptococcus pneumoniae mutant which does not require choline or analogs for growth. Journal of Bacteriology, v. 180, n. 8, p. 2093-2101, 1998.

10 YOTHER, J.; BRILLES, D. E. Structural properties and evolutionary relationships of PspA, a surface protein of Streptococcus pneumoniae, as revealed by sequence analyses. Journal of Bacteriology, v. 174, p. 601-609, 1992.

11 HOLLINGSHEAD, S. K.; BECKER, R.; BRILES, D. E. Diversity of PspA: mosaic genes and evidence for past recombination in Streptococcus pneumoniae. Infection and Immunity, v. 68, p. 5889-5900, 2000.

12 JEDRZEJAS, M. J.; LAMANI, E.; BECKER, R. S. Characterization of selected strains of Pnemococcal surface protein A. The Jornal of Biological Chemistry, v. 276, n. 25, 33121-33128, 2001.

13 GRANDICS, P.; SZATHMARY, S.; SZATHMARY, Z.; O'NEILL, T. Integration of cell culture with continuous, on line sterile downstream process. Annals of the New York Academy of Sciences, v. 646, p. 322-333, 1991.

14 RIESENBERG, R.; GUTHKE, R. High cell density cultivation of microorganisms. Applied Microbiology and Biotechnology, v. 51, p. 422-430, 1999.

15 SHILOACH, J.; FASS, R. Growing E. coli to high cell density - a historical perspective on method development - review. Biotechnology Advances, p. 345357, v. 23, 2005.

16 LEE, S. Y. High cell-density culture of Escherichia coli - reviews. Tibtech, v. 14, p. 98-105, 1996.

17 RAVI, G.; ELLA, K.; NARASU, M. L. Development of pilot scale production process and characterization of a recombinat multiepitope malarial vaccine candidate FALVAC-1A expressed in Escherichia coli. Protein Expression and Purification, v. 61, p. $57-64,2008$.

18 SHI, Y. P.; DAS P.; HOLLOWAY, B.; UDHAYAKUMAR, V.; TONGREN, J. E.; CANDAL, F.; BISWAS, S.; AHMAD, R.; HASNAIN, S. E.; LAL, A. A. Development expression and murine testing of a multistage Plamidium falciparum malaria vaccine candidate. Vaccine, v. 18, p. 2902-2914, 2000.

19 ZHOU, Z.; SCHNAKE, P.; XIAO, L.; LAL, A. A. Enhanced expression of a recombinant malaria candidate vaccine in Escherichia coli by codon optimization. Protein Expression and Purification, v. 34, p. 87-94, 2004.

20 SUÁREZ, D. C.; KILIKIAN B. V. Acid acetic accumulation in aerobic growth of recombinant E. coli. Process Biochemistry, p. 1051-1055, v. 35, 2000. 
21 DE MEY, M.; DE MAESENEIRE, S.; SOETAERT, W.; VANDAMME, E. Minimizing acetate formation in $E$. coli fermentations. Journal of Industrial Microbiology \& Biotechnology, v. 34, n. 11, p. 689-700, 2007.

22 GOMBERT, A. K.; KILIKIAN, B. V. Recombinant gene expression in Escherichia coli cultivation using lactose as inducer. Journal of Biotechnology, v.60, p. 47-54, 1998.

$23 \mathrm{KILIKIAN} \mathrm{B.} \mathrm{V.} \mathrm{et} \mathrm{al.} \mathrm{Process} \mathrm{strategies} \mathrm{to} \mathrm{improve} \mathrm{hetrologous} \mathrm{protein} \mathrm{production}$ in E. coli under lactose or IPTG induction. Process Biochemistry, v. 35, p. 10191025, 2000.

24 PINSACH, J.; MAS, C.; LÓPEZ-SANTÍN, J. Induction strategies in fed-batch cultures for recombinant protein productions in Escherichia coli: application to rhamnulose 1-phosphate aldolase. Biochemical Engineering Journal, v. 41, p. 181-187, 2008.

25 LEE, J.; SARASWAT, V.; KOH, I.; SONG, K. B.; PARK, Y. H.; RHEE, S. K. Secretory production of Artrobacter levan fructotransferase from recombinant Escherichia coli. FEMS Microbiology Letters, v. 195, p. 127-132, 2001.

26 UNIVERSIDADE FEDERAL DE MINAS GERAIS. Aula expositiva: controle da expressão gênica em procariontes. Disponível em: <http://www.icb.ufmg.br/prodabi/grupo7/iniciar/aulaexp/exp1-2.html>. Acesso em: 20 mar. 2007.

27 pET System Manual. NOVAGEN. 11. ed. Darmstadt: EMD Biosciences, 2003, p. 11.

28 SCOPES, R. K. Protein purification: principles and practice. 3. ed. New York: Springer Verlag, 1994.

29 WHEELWRIGHT, S. M. Protein purification: desing and scale up of downstream processing. Munich: Hanser Publishers, 1991.

30 DE OLIVEIRA, J. E.; SOARES, C. R.; PERONI, C. N.; GIMBO, E.; CAMARGO, I. M.; MORGANTI, L.; BELLINI, M. H.; AFFONSO, R.; ARKATEN, R. R.; BARTOLINI, P.; RIBELA, M. T. High-yield purification of biosynthetic human growth hormone secreted in Escherichia coli periplasmic space. Journal of Chromatography A, v. 852, p. 441-450, 1999.

31 SILVA, M.; CABRERA-CRESPO, J.; SBROGIO-ALMEIDA, M. E.; MIYAJI, E. N.; HO, P. L.; LEITE, L. C.; LOPES, A. P. Optimizing expression of Streptococus pneumoniae surface protein A, PspA: serocross-reactivity within families of antisera induced against clades 1 and 3. Molecular Biotechnology, v. 37, n. 2, p. 146-154, 2007. 
32 ASENJO, J. A.; ANDREWS, B. A. Protein purification using chromatography: selection of type, modelling and optimization of operating conditions. Wiley InterScience, v. 22, p. 65-76, 2008.

33 SILVA JR., J. G. Cromatografia de proteínas: guia teórico e prático. Rio de Janeiro: Interciência, 2004.

34 WOO-SEOK, C.; MIDDELBERG, A. P. J. Direct chemical extraction of a recombinant viral coat protein from Escherichia coli at high cell density. Biotechnoloy and Bioengineering, v. 75, n. 4, p. 451-455, 2001.

35 XINDU, G.; LILI, W. Liquid chromatography of recombinant proteins and protein drugs - review. Journal of Chromatography B, v. 866, p. 133-153, 2008.

36 IUT PROVENCE ARLES. Protéine compostition: M.M, pl, composition, titrate. Disponível em: <http://www.iut-arles.up.univ-mrs.fr/cgi-w3bb/a-compo-p.pl>. Acesso em: 13 fev. 2008.

37 SEEGER, A.; SCHNEPPE, B.; MCCARTHY, J. E. G.; DECKWER, W. D.; RINAS, U. Comparison of temperature-induced and isopropyl-beta-d-thiogalacto-pyranosideinduced synthesis of basic fibroblast growth-factor in high-cell-density cultures of recombinant Escherichia coli. Enzyme and Microbial Technology., v. 17, n. 10. p. 947-953, 1995.

38 AMERSHAM BIOSCIENCES HANDBOOK. Hydrophobic interaction chromatography: principles and methods. $A B$ ed. San Francisco: Amersham pharmacia Biotech, 1993.

39 LOWRY, O. H.; ROSENBROUGH, N. J.; FARR, R. H. Protein measurement with folin phenol reagent. Journal of Biological Chemistry, v. 193, p. 265-275, 1951.

40 LAEMMLI, U. K.; BEGUIN, F.; GUJER-KELLENBERGER, G. A factor preventing the major head protein of bacteriophage T4 from random aggregation. Journal of Molecular Biology, v. 47, p. 69-74, 1970.

41 MIYAJI, E. N.; FERREIRA, D. M.; LOPES, A. P.; BRANDILEONE, M. C.; DIAS, W. O.; LEITE, L. C. Analysis of serum crossreactivity and cross-protection elicited by immunization with DNA vaccines against Streptococcus pneumoniae expressing PspA fragments from different clades. Infection and Immunity, v. 70, p. 5086-5090, 2002.

42 KELLY, S. M.; JESS, T. J.; PRICE, N. C. How to study proteins by circular dichroism review. Biochimica et Biophysica Acta, v. 1751, p. 119-139, 2005.

43 HARCUM, S.W.; RAMIREZ, D.M.; BENTLEY, W. E. Optimal nutrient feed policies for heterologous production. Applied Biochemistry Biotechnology, v. 34/5, p. 161173, 1992. 
44 ZHANG, J.; GREASHAM, R. Chemically defined media for commercial fermentations. Applied Microbiology and Biotechnology, p. 407-421, v. 51, 1999.

45 MARTÍNEZ, K.; DE ANDA, R.; HERNÁNDEZ, G.; ESCALANTE, A.; GOSSET, G.; RAMÍREZ, O. T.; BOLÍVAR, F. G. Coutilization of glucose and glycerol enhances the production of aromatics compounds in an Escherichia coli strain lacking the phosphoenolpyruvate: carbohydrate phosphotranferase system. Microbial Cell Factories, v. 7, n.1, 2008. doi: 10.1186/1475-2859-7-1.

46 GNOTH, S.; JENZSCH, M.; SIMUTIS, R. Control of cultivation processes for recombinant protein production: a review. Biprocess and Biosystems Engeneering, v. 31, p. 21-39, 2008.

47 NOVELLA, I. S.; FARQUES, C.; GRÉVILLOT, G. Improvement of the extraction of penicillin acylase from Escherichia coli cells by a combined use of chemical methods. Biotechnology Bioengineering, v. 44, n. 3, p. 379-382, 1994.

48 DANILEVICH, V. N.; PETROVSKAIA, L. E.; GRISHIN, E. V. Rapid and efficient extraction of soluble proteins from gram-negative microorganisms without disruption of cell walls. Bioorganicheskaia Khimiia, v. 32, n. 6, p. 579-588, 2006.

49 WONG, H. H.; O’NEILL, B. K.; MIDDELBERG, A. P. J. Cumulative sedimentation analysis of Escherichia coli debris size. Biotechnology and Bioengineering, v. 55, n. 3, 1997.

50 GOYAL, D.; SAHOO, D. K.; SAHNI, G. Hydrophobic interaction expanded bed adsorption chromatography (HI-EBAC) based facile purification of recombinant streptokinase from E. coli inclusion budies. Journal of Chromatography B, v. 380, p. 384-391, 2007.

51 GOYAL, D.; SAHNI, G.; SAHOO, D. K. Enhanced production of recombinant streptokinase in Escherichia coli using fed-batch culture. Bioresource Technology, v. 100, p. 4468-4474, 2009.

52 ROLLAND, D.; GAUTHIER, M.; DUGUA, J. M.; FOURNIER, C.; DELPECH, L.; WATELET, B.; LETOURNEUR, O.; ARNAUD, M.; JOLIVET, M. Purification of recombinant $\mathrm{HBc}$ antigen expressed in Escherichia coli and Pichia pastoris: comparison of size-exclusion chromatography and ultracentrifugation. Journal Chromatography B, v. 751, n. 1, p. 51-65, 2001.

53 STRYER, L. Biochemistry. 3. ed. W. H. New York: Freeman and Company, 1988.

54 LUCARINI, A. C.; KILIKIAN, B. V., PESSOA JR. A. Precipitação. In: Purificação de produtos biotecnológicos. Barueri: Manole, 2005. p. 89-113.

55 BRAMAUD, C.; AIMAR, P.; DAUFIN, G. Whey protein fractionation: isoelectric precipitation of a-lactoalbumin under gentle heat treatment. Biotechnology and Bioengineering, v. 56, n. 4, p. 391-397, 1997. 
56 TASHIMA, A. K.; OTTENS, M.; VAN DER WIELEN, L. A.; CINTRA, D. E.; PAULI, J. R.; FILHO, P. D. E. A.; MIRANDA, E. A. Precipitation of porcine insulin with carbone dioxide. Biotechnology and Bioengineering, v. 103, n. 5, p. 909-919, 2009.

57 THE SCRIPPS RESEARCH INSTITUTE. Protein calculator. Disponível em: <http://www.scripps.edu/ cdputnam/protcalc.html>. Acesso em: 20 de fev. 2009.

58 GONZÁLEZ, C.; LAGOS, R.; MONASTERIO, O. Recovery of soluble protein after expression in Escherichia coli depends on cellular disruption conditions. Microbios, v. 85, n. 345, p. 205-212, 1996.

59 KILIKIAN, B. V.; PESSOA JR. A. Integração de processos. In: Purificação de produtos biotecnológicos. Barueri: Manole, 2005. p. 428-440.

60 GE HEALTHCARE. Protein purification. In: Products for life sciences 2007. p. 506-719, 2007. 


\section{ANEXos}

Características e condições de uso das resinas utilizadas neste trabalho segundo o fabricante (Amersham Pharmacia Biotech - GE HealthCare)

Informações obtidas do catálogo GE HealthCare $2007^{60}$ das seguintes resinas:
A. Sephacryl S-200 HR - Resina de gel filtração
B. Phenyl-Sepharose 6 high sub Fast-Flow - Resina hidrofóbica
C. Q-Sepharose Fast-Flow - Resina de troca aniônica
D. SP-Sepharose Fast-Flow - Resina de troca catiônica
E. IMAC-Sepharose Fast-Flow - Resina de afinidade por metal

Cada resina possui duas páginas de informações, sendo a primeira introdutória e a segunda as melhores condições de uso como fluxo máximo, capacidade, etc. 
A. Sephacryl S-200 HR pré-empacotada - Resina de gel filtração

Chromatography Columns and Media

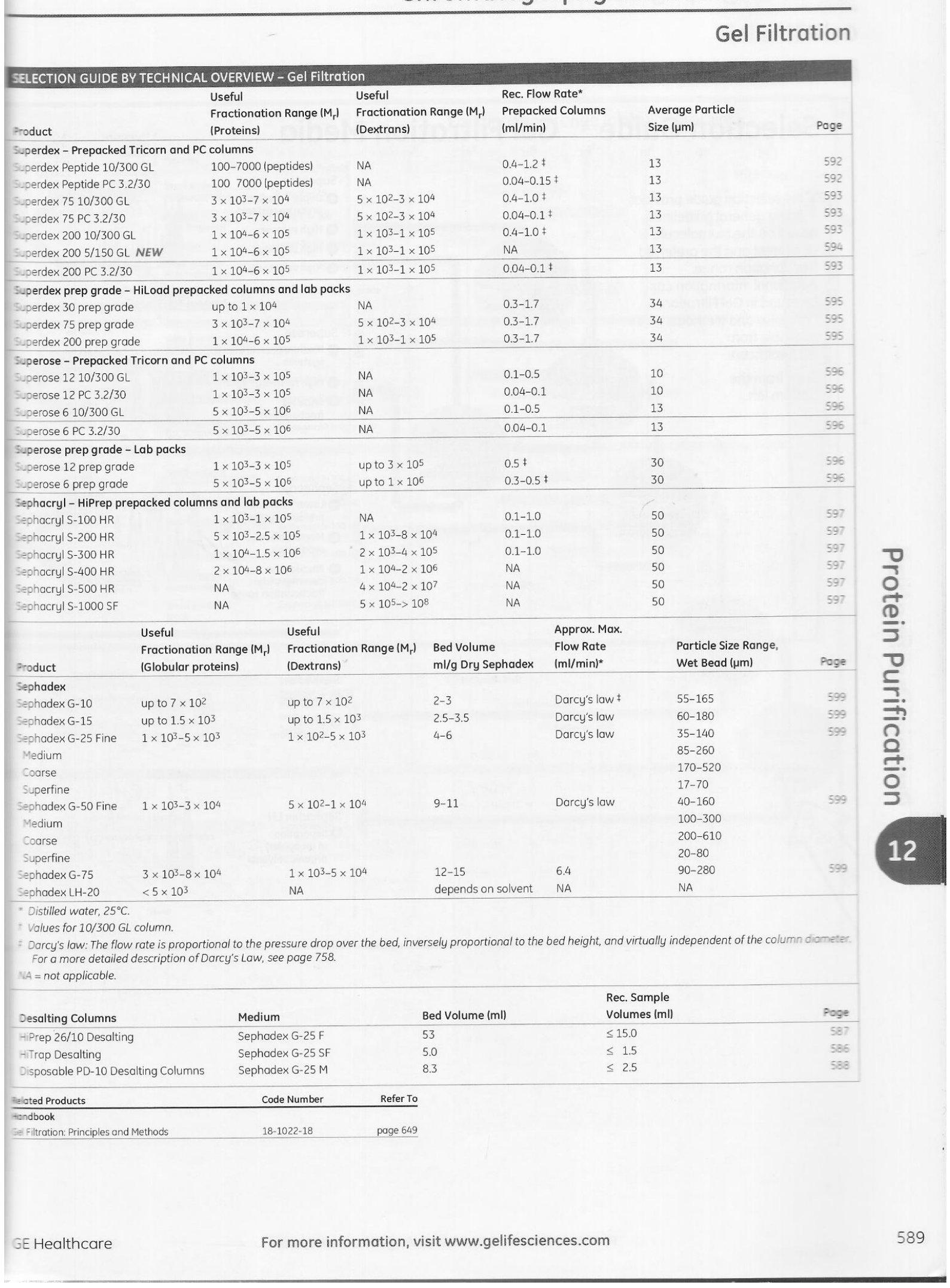




\section{Chromatography Columns and Media}

Gel Filtration

\section{HiPrep Sephacryl HR Columns and Sephacryl Lab Packs}

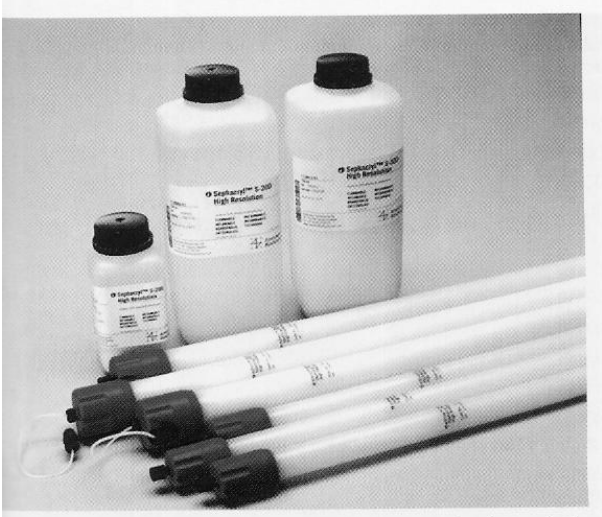

ep Sephacryl HR columns, prepacked with Sephacryl High Resolution media ide reliable gel filtration separations.

Maximum recovery and minimum nonspecific adsorption with long-term chemical and physical stability resulting from the hydrophilic, rigid allyl dextran/ bisacrylamide matrix.

Sephacryl S-100 HR is designed for separating peptides and small proteins.

S-200 HR and S-300 HR are for purifying antibodies, serum proteins, and mid-size proteins.

5-400 HR and S-500 HR are used to separate

polysaccharides, macromolecules with extended structures, and even small plasmids.

5-1000 SF is optimized for the purification of dextrans up to

108 molecular weight, spherical particles up to $400 \mathrm{~nm}$, and

DNA up to 20000 base pairs including plasmids, vesicles, and viruses.

$\begin{array}{llll} & 1 & 17-1167-01 & \$ 340.00\end{array}$

- BioProcess media. Process-scale quantities are available.

\begin{tabular}{llr} 
Related Products & Code Number & Refer To \\
\hline HiTrap/HiPrep, 1/16" male connector for ÄKTAdesign & $28-4010-81$ & page 512 \\
$\begin{array}{l}\text { Handbook } \\
\text { Gel Filtration: Principles and Methods }\end{array}$ & $18-1022-18$ & \\
\hline
\end{tabular}

\begin{tabular}{|c|c|}
\hline Prepacked HiPrep Columns* & \\
\hline Bed dimensions & \\
\hline HiPrep $16 / 60$ & $16 \times 600 \mathrm{~mm}$ \\
\hline HiPrep 26/60 & $26 \times 600 \mathrm{~mm}$ \\
\hline Bed volume & \\
\hline HiPrep $16 / 60$ & $120 \mathrm{ml}$ \\
\hline HiPrep 26/60 & $320 \mathrm{ml}$ \\
\hline Sample volume & \\
\hline HiPrep $16 / 60$ & $\leq 5 \mathrm{ml}$ \\
\hline HiPrep 26/60 & $\leq 13 \mathrm{ml}$. \\
\hline Rec. linear flow rate & $5-15 \mathrm{~cm} / \mathrm{h}$ \\
\hline $\begin{array}{l}\text { Max. linear flow rate } \\
\left(\mathrm{H}_{2} \mathrm{O} \text { at } 25^{\circ} \mathrm{C}\right)\end{array}$ & $30 \mathrm{~cm} / \mathrm{h}$ \\
\hline $\begin{array}{l}\text { Max. pressure over the } \\
\text { packed bed during operation }\end{array}$ & 1.5 bar (22 psi, $0.15 \mathrm{MPa})$ \\
\hline Column hardware pressure limit & 5 bar (73 psi, $0.5 \mathrm{MPa})$ \\
\hline Theoretical plates & $5000 m^{-1}$ \\
\hline
\end{tabular}

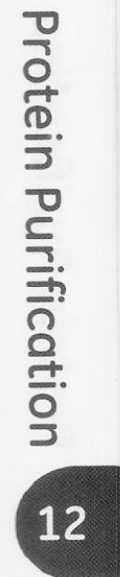




\section{B. Phenyl-Sepharose 6 high sub Fast-Flow - Resina hidrofóbica}

\section{Chromatography Columns and Media}

Hydrophobic Interaction

\section{Introduction to Hydrophobic Interaction}

drophobic interaction chromatography $(\mathrm{HIC})$ is a versatile thod for the purification and separation of biomolecules ssed on differences in their surface hydrophobicity. Proteins id peptides usually sequence hydrophobic amino acids in hains away from the surface of the molecule. However, ny biomolecules considered hydrophilic have sufficient drophobic groups exposed to allow interaction with idrophobic ligands attached to the chromatographic matrix. mpared to reversed phase chromatography, the density of ligand on the matrix is much lower. This feature promotes e high selectivity of HIC, while allowing mild elution conditions help preserve biological activity.
Hydrophobic interaction between a biomolecule and the matrix is enhanced by high ionic strength buffers. This makes HIC an ideal "next-step" for the purification of materials that have been precipitated with ammonium sulfate or eluted in high salt concentrations during ion exchange chromatography

\begin{tabular}{lcc} 
Related Products & Code Number & Refer To \\
\hline $\begin{array}{l}\text { Handbook } \\
\text { Hydrophobic Interaction and Reversed Phase }\end{array}$ & $11-0012-69$ & poge 649
\end{tabular}

Hydrophobic Interaction and Reversed Phase $11-0012-69$ poge 6 Chromatography

Selection Guide - Hydrophobic Interaction Chromatography Media

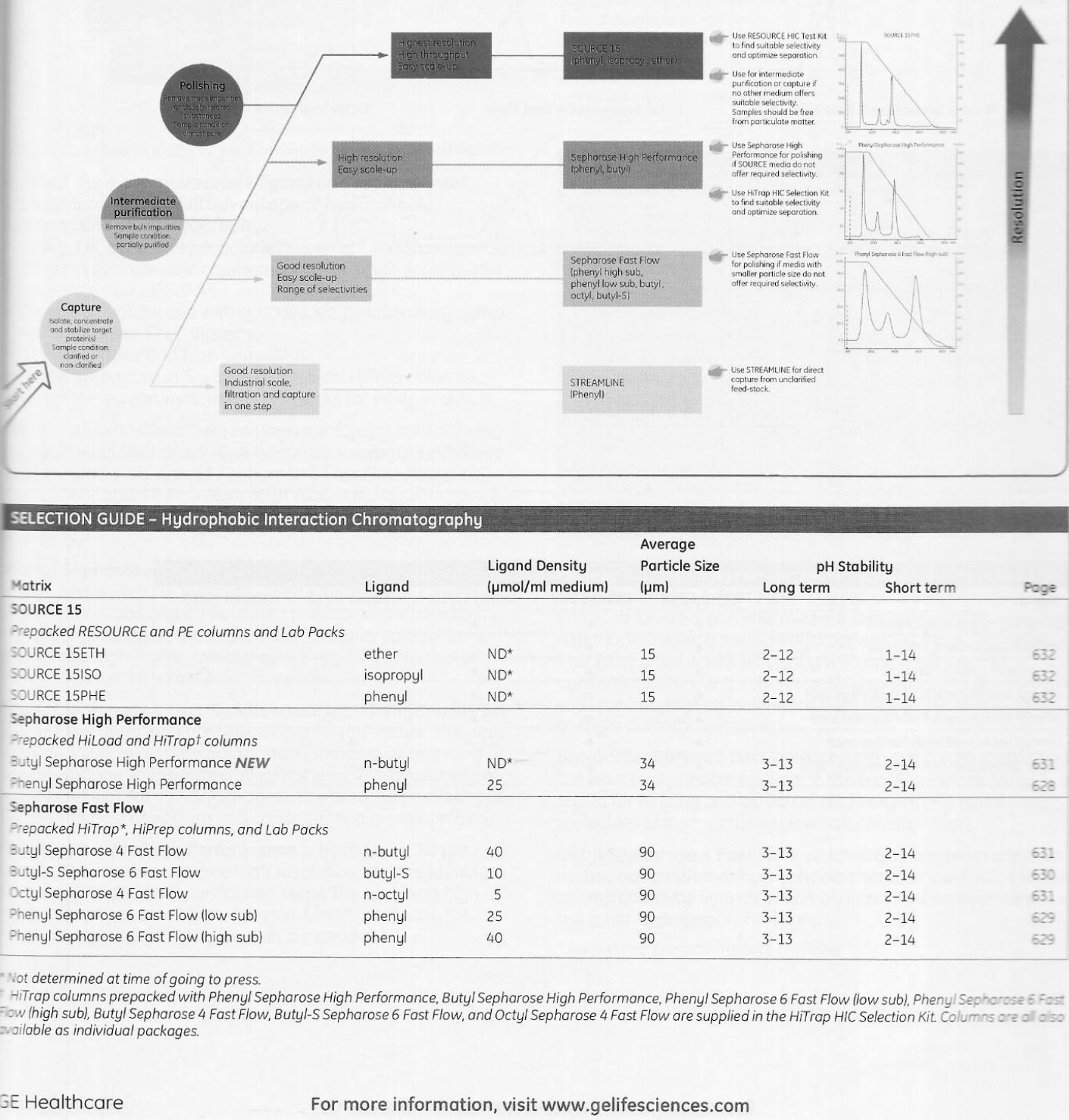




\section{Chromatography Columns and Media}

Hydrophobic interaction

\section{J Phenyl Sepharose 6 Fast Flow}

Available with high or low levels of phenyl substitution differing in selectivity, efficiency, and binding capacity.

- The standard (low sub) and high-capacity (high sub) aromatic HIC media are made of highly cross-linked $90-\mu \mathrm{m}$ agarose beads derivatized with phenyl groups via uncharged,

chemically stable ether linkages.

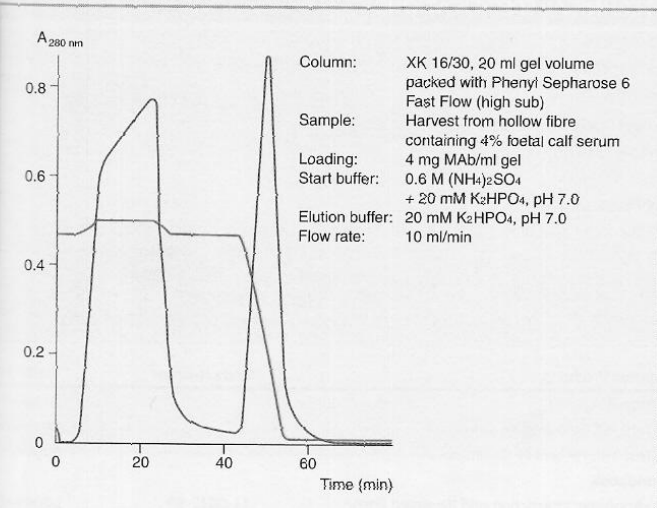

olation of a monoclonal antibody, $\operatorname{lgG}_{1}$ with Phenyl Sepharose 6 Fast Flow (high

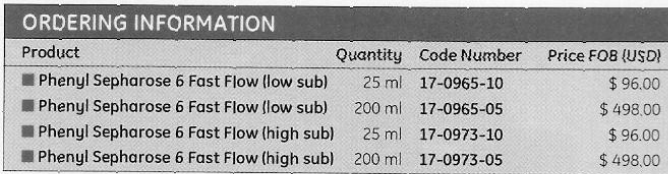

- Bioprocess media. Process quantities are available.

\begin{tabular}{|c|c|c|}
\hline Related Products & Code Number & Refer To \\
\hline HiPrep $16 / 10$ Phenyl FF (thigh sub) & $17-5095-01$ & page 627 \\
\hline HiPrep 16/10 Phenyl FF (low sub) & $17-5094-01$ & page 627 \\
\hline HiTrap HIC Selection Kit NEW & & page 625 \\
\hline HiTrap HIC HP and FF Columns & & page 626 \\
\hline \multicolumn{3}{|l|}{ Handbook } \\
\hline $\begin{array}{l}\text { Hydrophobic Interaction and Reversed Fhase } \\
\text { Chromatography }\end{array}$ & $11-0022-69$ & page 649 \\
\hline
\end{tabular}

\begin{tabular}{|c|c|}
\hline \multicolumn{2}{|l|}{ TECHNICAL SPECIFICATIONS } \\
\hline \multicolumn{2}{|l|}{ Ligand density } \\
\hline Phenyl Sepharose 6 Fast Flow (low subl & $25 \mu \mathrm{mol} / \mathrm{ml}$ medium \\
\hline Phenyl Sepharose 6 Fast Flow (high sub) & $40 \mathrm{umol} / \mathrm{m} / \mathrm{medium}$ \\
\hline Binding capacity & \\
\hline Phenyl Sepharose 6 Fast Flow (low sub) & $\begin{array}{l}10 \mathrm{mg} \mathrm{gg} / \mathrm{ml} \text { medium } \\
24 \mathrm{mg} \mathrm{HSA} / \mathrm{ml} \text { medium }\end{array}$ \\
\hline Phenyl Sepharose 6 Fast Flow (high sub) & $\begin{array}{l}30 \mathrm{mg} / \mathrm{gG} / \mathrm{m} / \text { medium } \\
36 \mathrm{mg} \mathrm{HSA} / \mathrm{ml} \text { medium }\end{array}$ \\
\hline Pressure/flow spec. & $\begin{array}{l}200-400 \mathrm{~cm} / \mathrm{h}, 1 \text { bar } X K 50 / 60 \\
\text { column, bed height } 25 \mathrm{~cm}\end{array}$ \\
\hline pH stability & $\begin{array}{l}\text { 2-14 (short term). 3-13 llong } \\
\text { term) }\end{array}$ \\
\hline Chemical stability & $\begin{array}{l}\text { Stable in common buffers, } \\
\text { chaotropic agents, detergents, } \\
\text { and polar organic solvents. }\end{array}$ \\
\hline Average particle size & $90 \mu \mathrm{m}$ \\
\hline
\end{tabular}




\section{Q-Sepharose Fast-Flow - Resina de troca aniônica D. SP-Sepharose Fast-Flow - Resina de troca catiônica}

\section{Chromatography Columns and Media}

\section{lon Exchange}

\section{SELECTION GUIDE BY TECHNICAL OVERVIEW - Ion Exchange Chromatography}

Exchanger Average Particle Size

$\begin{array}{lllll}\text { Matrix } & \begin{array}{l}\text { Exchanger } \\ \text { Type }^{*}\end{array} & \begin{array}{l}\text { Average Particle Size } \\ \text { Wet Bead }(\mu \mathrm{m})\end{array} & \text { Long Term Stability }\end{array}$

MiniBeads Columns
Prepacked Tricorn and PC columns

Minio

Mini Q
Mini S

Strong onion

Strong anion

Strong cation

3

MonoBeads Columns

Prepacked Tricorn and PC columns

Mono Q

MonoS

Mono $P$

Strong anion

Strong cation

Weak anion

3

2-12

2-12

SOURCE 15

Prepacked Tricorn, RESOURCE columns, and lab packs

SOURCE 150

SOURCE $15 S$

Strong anion

SOURCE 30

Strong cation

SOURCE $30 Q$

Strong anion

Strong cation

10

$10 \quad 2-12$

10

2-12

$1-14$

SOURCE 305

Strong cation $\quad 30$

15

2-12

2-12

30

2-12

$2-12$
$2-12$

1-14

Sepharose High Performance

Prepacked HiLoad, HiTrap columns, and lab packs

Q Sepharose High Performance Strong anion

SP Sepharose High Performance Strong cation

$34(24-44)$

$34(24-44)$

2-12

$2-14$

Capto

Prepacked HiTrap columns and lab packs

Capto MMC Multimodal, weak cation 75

Capto 0

Capto S

Strong anion

$75 \quad 2-12$

$2-12$

90

\begin{tabular}{ll}
$2-12$ & $2-14$ \\
\hline
\end{tabular}

Prepacked HiPrep. HiTrap columns, and lab packs

P Sepharose Fast Flow

SP Sepharose Fast Flow

SP Sepharose

ANX Sepharose 4 Fast Flow (high sub) Weak anion

Weak anion

Weak cation

$90(45-165)$

$90(45-165)$

$90(45-165)$

Sepharose XL

$90(45-165)$

$2-12$

2-12 $1-14$

3-13

4-13

Prepacked HiPrep, HiTrap columns, and lab packs

Q Sepharose XL Strong anion

SP Sepharose

Strong anion
Strong cation

$90(45-165)$

$90(45-165)$

3-13

$3-13$

$3-14$

* Strong ion exchangers are ionized over a wide $\mathrm{pH}$ range and have almost constant ionic capacity within this range. Strong exchangers may also exhibit slightly bet. selectivity than weak ones. Weak ion exchangers are only ionized over a limited $\mathrm{pH}$ range and may start to lose their charge at pH values below 6 /cation exchangere above 9 (anion exchangers).

\section{SELECTION GUIDE-Overview of HiTrap, HiPrep, and HiLoad Prepacked Columns for IEX}

\begin{tabular}{|c|c|c|c|c|c|}
\hline Media & HiTrap $1 \mathrm{ml}$ & HiTrap $5 \mathrm{ml}$ & HiPrep $16 / 10$ & HiLoad $16 / 10$ & HiLoad 26/10 \\
\hline ANX Sepharose 4 Fast Flow (high sub) & - & - & $\bullet$ & - & - \\
\hline Capto MMC & $\bullet$ & - & - & - & - \\
\hline Capto Q & $\bullet$ & - & - & - & - \\
\hline Capto S & - & - & - & - & - \\
\hline CM Sepharose Fast Flow & $\bullet$ & - & - & - & - \\
\hline DEAE Sepharose Fast Flow & • & • & • & - & - \\
\hline Q Sepharose Fast Flow & $\bullet$ & - & - & - & - \\
\hline Q Sepharose High Performance & $\bullet$ & - & - & - & $\bullet$ \\
\hline Q Sepharose XL & $\bullet$ & $\bullet$ & $\bullet$ & - & - \\
\hline SP Sepharose Fast Flow & $\bullet$ & . $\bullet$ & $\bullet$ & - & - \\
\hline SP Sepharose High Performance & $\bullet$ & - & - & - & $\bullet$ \\
\hline SP Sepharose XL & $\bullet$ & $\bullet$ & $\bullet$ & - & - \\
\hline
\end{tabular}




\section{Chromatography Columns and Media}

\section{Ion Exchange}

\section{- Sepharose Fast Flow IEX}

- For preparative purifications, even when purifying crude samples.

- Available with strong (Q and SP) and weak (DEAE, CM, and ANX) anion and cation exchangers, in bulk quantities and in prepacked HiTrap and HiPrep columns, as well as HiTrap IEX Selection Kit.

- For separation of proteins of all pl values with Q and SP having a high dynamic capacity for proteins over the entire $\mathrm{pH}$ range.

- ANX has a different selectivity compared to DEAE, and is applicable for separation of high molecular weight proteins.

- Easy scale-up from HiTrap scale to laboratory scale to process scale.

\section{TECHNICAL SPECIFICATIONS}

Ion exchanger type

Q Sepharose FF

DEAE Sepharose FF

ANX Sepharose $4 \mathrm{FF}$

SP Sepharose FF

CM Sepharose FF

Ionic capacity

Q Sepharose FF

DEAE Sepharose FF

ANX Sepharose 4 FF

SP Sepharose FF

CM Sepharose FF

Dynamic capacity

Q Sepharose FF

DEAE Sepharose FF

ANX Sepharose $4 \mathrm{FF}$

SP Sepharose FF

CM Sepharose FF

Pressure/flow spec.

Q Sepharose FF

DEAE Sepharose FF

ANX Sepharose 4 FF

SP Sepharose FF

CM Sepharose FF

Average particle size

Matrix

Sepharose FF

Sepharose $4 \mathrm{FF}$

$\mathrm{pH}$ stability

Q Sepharose FF

DEAE Sepharose FF

ANX Sepharose 4 FF

SP Sepharose FF

CM Sepharose FF

Chemical stability Diethylaminoethyl weak anion Diethylaminopropyl weak anion

Sulfopropyl strong cation

Carboxymethyl weak cation

$0.18-0.25 \mathrm{mmol} / \mathrm{Cl}-1 / \mathrm{m}$

$0.11-0.16 \mathrm{mmol} / \mathrm{Cl}-1 / \mathrm{ml}$

$0.18-0.25 \mathrm{mmol}(\mathrm{H}+1 / \mathrm{ml}$

$0.09-0.13 \mathrm{mmol}(\mathrm{H}+) / \mathrm{ml}$

$120 \mathrm{mg} \mathrm{HSA} / \mathrm{ml}$ medium

$110 \mathrm{mg} \mathrm{HSA} / \mathrm{ml}$ medium

$5 \mathrm{mg}$ thyroglobulin/ml medium

$70 \mathrm{mg}$ RNase/ml medium

$50 \mathrm{mg} \mathrm{RNase} / \mathrm{ml}$ medium

$400-700 \mathrm{~cm} / \mathrm{h}, 100 \mathrm{kPa}$, XK 50/30 column bed height $15 \mathrm{~cm}$

$300-600 \mathrm{~cm} / \mathrm{h}, 100 \mathrm{kPa}$, XK 50/30 column, bed height $15 \mathrm{~cm}$

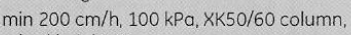
bed height $25 \mathrm{~cm}$

$400-700 \mathrm{~cm} / \mathrm{h}, 100 \mathrm{kPa}, \times K 50 / 30$ column bed height $15 \mathrm{~cm}$

$300-600 \mathrm{~cm} / \mathrm{h}, 100 \mathrm{kPa}$, XK $50 / 30$ column

bed height $15 \mathrm{~cm}$

$90 \mu \mathrm{m}(45-165 \mu \mathrm{m})$

Highly cross-linked agarose, $6 \%$

Highly cross-linked agarose, $4 \%$

1-14 (short term), 2-12 (long term)

1-14 (short term), 2-13 (long term)

2-14 (short term), 3-13 (long term)

3-14 (short term), 4-13 (long term)

2-14 (short term), 4-13 (long term)

Stable in all common aqueous buffers: $8 \mathrm{M}$ urea, $6 \mathrm{M}^{*}$ guanidine $\mathrm{HCl}, 70 \%$ eth
$1 \mathrm{M} \mathrm{NaOH}^{*}$, and $1 \mathrm{M}$ acetic acid*.
Quaternary ammonium strong anion

$0.13-0.18 \mathrm{mmol} / \mathrm{Cl}-1 / \mathrm{m}$

\section{ORDERING INFORMATION}

Product

Q Q Sepharose Fast Flow

- Q Sepharose Fast Flow

- DEAE Sepharose Fast Flow

mDEAE Sepharose Fast Flow

- SP Sepharose Fast Flow

= SP Sepharose Fast Flow

I CM Sepharose Fast Flow

CM Sepharose fast Flow

aNX Sepharose 4 Fast Flow (high sub)

- ANX Sepharose 4 Fast Flow (high sub)

Quantity Code Number Price FOB (USD]

$25 \mathrm{ml} 17-0510-10 \quad \$ 53 \mathrm{ar}$

$300 \mathrm{ml} 17-0510-01 \quad \$ 31507$

$25 \mathrm{ml} \quad 17-0709-10 \quad \$ 52 a \mathrm{at}$

$500 \mathrm{ml}$ 17-0709-01 $\$ 3900$

$25 \mathrm{ml} \quad 17-0729-10 \quad 553 \mathrm{~m}$

$300 \mathrm{ml} \mathrm{17-0729-01 \quad \$ 315 \pi 7}$

$25 \mathrm{ml} 17-0719-10-5502$

$25 \mathrm{ml} 17-0719-10-5520$

$500 \mathrm{ml} 17-0719-01 \quad \$ 390 \mathrm{nt}$

$500 \mathrm{ml}-17-1287-01$

$586 \pi$

- BioProcess media. Process-scale quantities are available. Reler 17

HiPrep 16/10 Sepharose FF IEX Columns

HiTrap Sepharose FF IEX Columns

Hilrop/HiPrep, 1/16" male connector for ÄKTAdesign [ 28-4010-81

HiTrap IEX Selection Kit

Handbook

Ion Exchange Chromatography \& Chromatofocusing: 11-0004-21 poge sete Principles and Method's

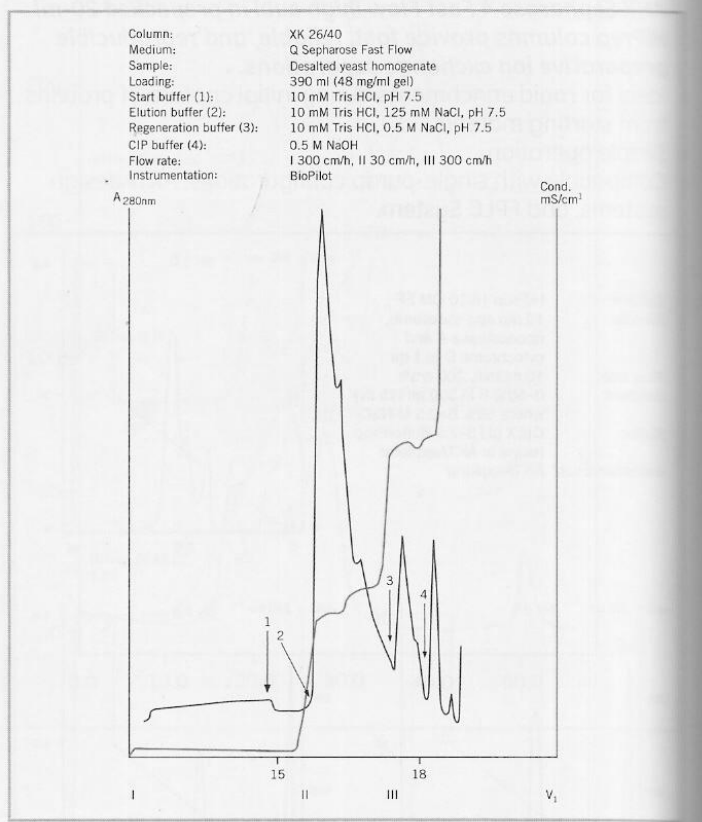

Recombinant human superoxide dismutase produced by Saccharomyces cerevisiae is purified directly from clarified cell homogenate on Q Sepharose
Flow after desalting and buffer exchange on Sephadex G-25. A $2.6 \times 5$ ml ion exchange column handles $390 \mathrm{ml}$ of sample in $45 \mathrm{~min}$. 
E. IMAC-Sepharose Fast-Flow - Resina de afinidade por metal Chromatography Columns and Media Affinity, Immobilized Lectin / Affinity, Metal Chelate

\section{Lentil Lectin Sepharose 4B}

Con $A$, binds $\alpha$-D-mannose, $\alpha$-D-glucose, and sterically uted residues, but lentil lectin distinguishes less sharply -ween glucosyl and mannosyl residues and binds simple gars with lower affinity.

Far hemagglutinin coupled to Sepharose $4 B$ via cyanogen -ide activation.

ns binding in $1 \%$ deoxycholate and is especially

uable for purification of detergent-solubilized membrane uteins.

and concentration is $\approx 2 \mathrm{mg} / \mathrm{ml}$ medium. The binding

socity for porcine thyroglobulin is $\approx 25 \mathrm{mg} / \mathrm{ml}$ medium.

\begin{tabular}{|c|c|c|c|}
\hline Product & Quantity & Code Number & Price FOB (USD) \\
\hline Lentil Lectin Sepharose 4B & $25 \mathrm{ml}$ & 17-0444-01 & $\$ 496.00$ \\
\hline \multicolumn{4}{|l|}{ References } \\
\hline \multicolumn{4}{|c|}{$\begin{array}{l}\text { 1. Hayman, M.J. et al. Purification of virus glycoproteins by affinity } \\
\text { chromatography using Lens culinaris phytohaemagglutinin. FEBS Lett. 29, } 185 \\
\text { (1973). } \\
\text { 2. Tsujimoto, M. et al. Purification and characterisation of recombinant human } \\
\text { interleukin } 5 \text { expressed in Chinese Hamster Ovary cells. J. Biochem. 106, } 23 \\
\text { (1989). } \\
\text { 3. Jackson, P.J. et al. Combined lectin-affinity and anion exchange } \\
\text { chromatography of serum glycoproteins to reveal induced glycan changes, } \\
\text { In: Lectins - Biology, Biochemistry, Clinical Biochemistry Vol. 6. Sigma Chemical } \\
\text { Company, St. Louis, MO, USA (1988). }\end{array}$} \\
\hline
\end{tabular}

ogens / Lectins

bin product entries, see page 79

\section{oduction to Metal Chelate Affinity}

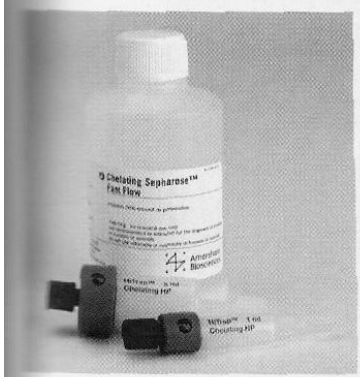

Metal chelate affinity chromatography s a useful separation technique applicable to most types of proteins.

Useful for histidine-tagged* proteins, but generally spplicable to most proteins with exposed histidine, cysteine, and tryptophan.

ghly selective affinities depending upon the metal ion used ch as $\mathrm{Cu}^{2+}, \mathrm{Zn}^{2+}, \mathrm{Ni}^{2+}, \mathrm{Ca}^{2+}, \mathrm{CO}^{2+}, \mathrm{Fe}^{3+}$.

Useful for purifying membrane proteins and protein

aggregates where detergents or high ionic strength buffers re required.

Yay be employed in analytical and preparative applications

ogether with ion exchange or hydrophobic interaction

nromatography steps.
Immobilized metal ion adsorption chromatography (IMAC) is also known as metal chelate affinity chromatography. In this technique, the medium is first charged with a transition metal ion to form a chelate before use. Proteins will bind to the medium depending upon the presence of surface histidine, cysteine, and tryptophan residues that have an affinity for chelated metal ions. The binding strength is affected principally by the metal ion and $\mathrm{pH}$ of the buffers. The bound protein can be eluted by competitive elution with, for example, imidazole, or by lowering $\mathrm{pH}$. Strong chelating agents, such as EDTA can also be used.

IMAC is an excellent chromatography technique for optimization and purification of histidine-tagged proteins. Optimization work can be preformed with IMAC Sepharose since that allows simple replacement of the immobilized meta ions. The metal ions most frequently used for optimization of purification are $\mathrm{Zn}^{2+}, \mathrm{Ni}^{2+}, \mathrm{CO}^{2+}, \mathrm{Ca}^{2+}, \mathrm{Cu}^{2+}$, and $\mathrm{Fe}^{3+}$.

Remember that other factors can affect the purity of histidinetagged protein. The tag position on the $\mathrm{C}$ or $\mathrm{N}$-terminus and the tag length are two factors that should be considered when optimization of a purification protocol is performed. 


\section{Chromatography Columns and Mèdia}

\section{Affinity, Metal Chelatet}

\section{IMAC Sepharose 6 Fast Flow Media/HiTrap IMAC FF Columns/ -Prep IMAC FF 16/10 Column}

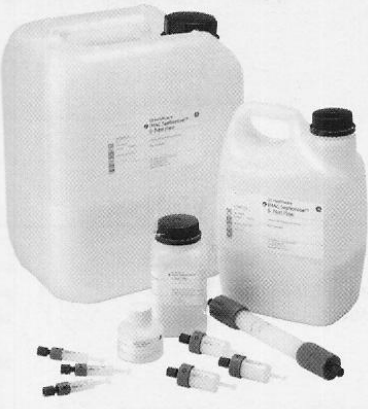

For optimizing purification of histidine-tagged* proteins wen $\mathrm{Ni}^{2+}$ is not the best choice of metal ion.

conveniently charge with your metal of choice.

ceal bead size for scaling up.

gh binding capacity.

repacked HiTrap columns for convenient purification. repacked HiPrep columns for easy scale-up.

- C Sepharose 6 Fast Flow consists of $90-\mu \mathrm{m}$ beads of highly ss-linked agarose to which a chelating group has been walently coupled. This chelating group can be charged with table metal ions, specific for your target protein of interest. bead size of IMAC Sepharose 6 Fast Flow enables high flow coerties, making the medium an ideal choice for scaling up fication at laboratory scale and purification of histidineged proteins at process scale.

metal ion leakage means ihat the activity of the purified rein is retained and the risk of precipitation reduced, which ilts in increased purity, activity, and yield of the target tein. Leakage of metal ions into the eluted target protein al from IMAC Sepharose 6 Fast Flow is generally low under al conditions.

Sepharose 6 Fast Flow is highly stable and compatible a wide range of common additives. This helps maintain gical activity and increase product yield, while at the same greatly expanding the range of suitable operating ditions.

medium is available prepacked in HiTrap and HiPrep unn formats for convenient purification of histidine-tagged teins at laboratory scale. Initial purification using a 1-ml rap IMAC FF column can be scaled up further with the 5-ml umn. Purification can be scaled up even more using 20-ml rep IMAC FF 16/10 columns.

licensing information at back of catalog.

\begin{tabular}{|lrlr|}
\hline ORDERING INFORMATION & & & \\
\hline Product & Quantity & Code Number & Price FOB IUSD) \\
\hline HiPrep IMAC FF 16/10 & $1 \times 20 \mathrm{ml}$ & $17-0921-06$ & $\$ 284.00$ \\
HiTrap IMAC FF & $5 \times 1 \mathrm{ml}$ & $17-0921-02$ & $\$ 102.00$ \\
HiTrap IMAC FF & $5 \times 5 \mathrm{ml}$ & $17-0921-04$ & $\$ 354.00$ \\
IMAC Sepharose 6 Fast Flow & $25 \mathrm{ml}$ & $17-0921-07$ & $\$ 189.00$ \\
\hline IMAC Sepharose 6 Fast Flow & $100 \mathrm{ml}$ & $17-0921-08$ & $\$ 640.00$ \\
\hline
\end{tabular}

nioProcess medium. Process-scale quantities are available.

\begin{tabular}{|c|c|c|}
\hline Related Products & Code Number & Refer To \\
\hline HisPrep Ff $16 / 10$ Column & & page 532 \\
\hline Histrap FF Columns & & page 529 \\
\hline Ni Sepharose 6 Fast Flow & & page 528 \\
\hline $\begin{array}{l}\text { HiTrap/HiPrep, 1/16" male connector for ÄKTAdesign } \\
\text { Handbooks }\end{array}$ & $28-4010-81$ & page 512 \\
\hline $\begin{array}{l}\text { Affinity Chromatography Handbook: Principles and } \\
\text { Methods }\end{array}$ & & page 649 \\
\hline Recombinant Protein Purification: Principles and Methods & & page 649 \\
\hline
\end{tabular}

\begin{tabular}{|c|c|}
\hline \multicolumn{2}{|l|}{ TECHNICAL SPECIFICATIONS } \\
\hline Matrix & Highly cross-linked agarose, $6 \%$ \\
\hline Average particle size & $90 \mu \mathrm{m}$ \\
\hline Binding capacity* & $\begin{array}{l}\sim 40 \mathrm{mg} \text { histidine-tagged protein } / \mathrm{m} / \text { medium } \\
\text { when charged with Nizt }\end{array}$ \\
\hline Compatibility & Stable in all commonly used buffers \\
\hline Chemical stabilityt & $\begin{array}{l}\text { For one week at } 40^{\circ} \mathrm{C}: 0.01 \mathrm{M} \mathrm{HCl}, 0.1 \mathrm{M} \mathrm{NaOH} \\
\text { For } 12 \mathrm{~h}: 1 \mathrm{M} \mathrm{NaOH}, 70 \% \text { acetic acid } \\
30 \mathrm{~min} \text { tested } 30 \% \text { 2-propanol } \\
1 \mathrm{~h} \text { tested } 2 \% \mathrm{SDS}\end{array}$ \\
\hline pH stability ${ }^{\dagger}$ & 3-12 llong term). 2-14 (short term) \\
\hline \multicolumn{2}{|l|}{ HiTrap prepacked columns } \\
\hline Column volume & $1 \mathrm{ml}$ and $5 \mathrm{ml}$ \\
\hline Column dimensions & $0.7 \times 2.5 \mathrm{~cm}(1 \mathrm{mll}, 1.6 \times 2.5 \mathrm{~cm}(5 \mathrm{ml})$ \\
\hline Recommended flow rate $\ddagger$ & $1 \mathrm{ml} / \mathrm{min}(1 \mathrm{ml}), 5 \mathrm{ml} / \mathrm{min}(5 \mathrm{ml})$ \\
\hline Max. pressureł & 3 bar $(0.3 \mathrm{MPa}, 42 \mathrm{psi})$ \\
\hline \multicolumn{2}{|l|}{ HiPrep prepacked columns } \\
\hline Column volume & $20 \mathrm{ml}$ \\
\hline Column dimensions & $1.6 \times 10 \mathrm{~cm}$ \\
\hline Recommended flow rate $\ddagger$ & $2-10 \mathrm{ml} / \mathrm{min}$ \\
\hline $\begin{array}{l}\text { Max. pressure over the packed } \\
\text { bed during operationt }\end{array}$ & 1.5 bar $(0.15 \mathrm{MPa}, 22 \mathrm{psil}$ \\
\hline $\begin{array}{l}\text { Column hardware pressure } \\
\text { limit }\end{array}$ & 5 bar $(0.5 \mathrm{MPa}, 73 \mathrm{psi})$ \\
\hline $\begin{array}{l}\text { * Protein- and metal-ion dependent. } \\
\text { t Medium uncharged with metal ion. } \\
\text { ₹ } \mathrm{H}_{2} \mathrm{O} \text { at room temperature. }\end{array}$ & \\
\hline
\end{tabular}

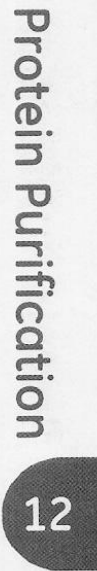

